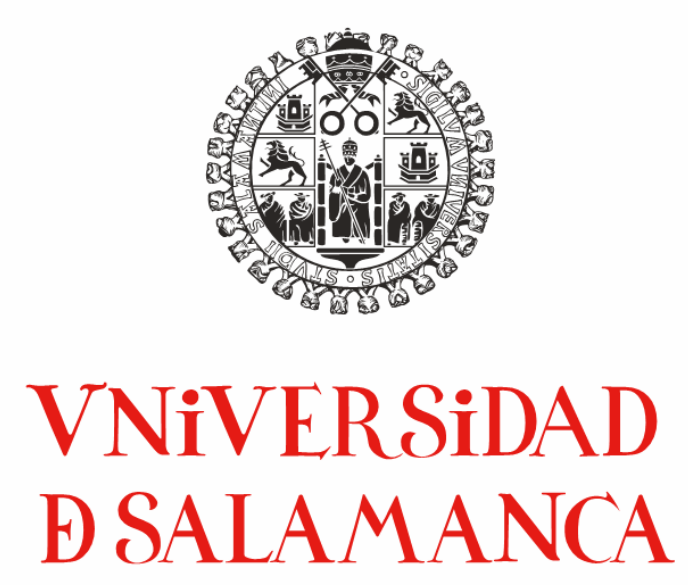

DEPARTAMENTO DE BIOQUÍMICA Y BIOLOGÍA MOLECULAR

\title{
El virus de la enfermedad de Newcastle: \\ Modelo de interacción virus-célula y vector de expresión
}

Juan Ayllón Barasoain

2009 

DON ENRIQUE VILLAR LEDESMA, CATEDRÁTICO DE UNIVERSIDAD, Y DOÑA Ma ISABEL MUÑOZ BARROSO, PROFESORA TITULAR DE UNIVERSIDAD, DEL DEPARTAMENTO DE BIOQUÍMICA Y BIOLOGÍA MOLECULAR DE LA UNIVERSIDAD DE SALAMANCA,

CERTIFICAN:

Que la presente Tesis Doctoral titulada "El virus de la enfermedad de Newcastle: modelo de interacción virus-célula y vector de expresión", que para optar al grado de Doctor en Biología presenta Don Juan Ayllón Barasoain, ha sido realizada bajo su dirección en el Departamento de Bioquímica y Biología Molecular de la Universidad de Salamanca.

Considerando que dicho trabajo se halla concluido, autoriza su presentación para que sea juzgado por el tribunal correspondiente.

Y, para que así conste, firman el presente certificado en Salamanca a 24 de Marzo de 2009.

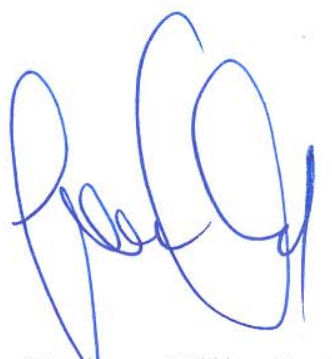

Dr. Enrique Villar Ledesma

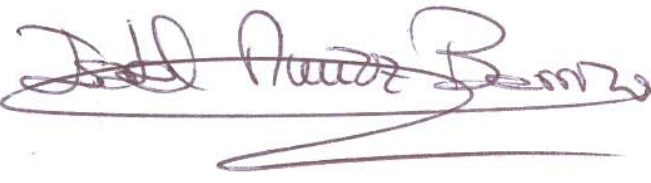

Dra. Mª Isabel Muñoz Barroso 

"Hasta el que hace una tesis sobre la sífilis acaba enamorándose de la espiroqueta pálida”

Umberto Eco 



\section{Agradecimientos}

A Enrique Villar Ledesma, por introducirme en la investigación, por su dirección y por la confianza depositada en mí. Nada de esto hubiera sucedido sin él.

A Isabel Muñoz Barroso, por su guía a través de las sendas de la fusión, por sus conocimientos y sus consejos.

A mis maestros. A Adolfo García Sastre, por aceptarme en su laboratorio y abrirme la puerta a un nuevo mundo. Y a Luis Martínez Sobrido, que me enseñó todo sobre ese mundo y muchísimas cosas sobre éste.

A la camaradería de mis compañeros Javier, Sara, Juanjo, Josemi, Lorena.

A la sabiduría de Valery Shnyrov.

A los que me enseñaron lo que es ser un científico y mucho más. A Anna Shnyrova, Vadim Frolov, Georg Kochs, Silke Stertz, Jerome Cros, Samira Mubareka... A tantos y tantas, en Bethesda y en Nueva York.

A Jose Miguel López Novoa, Alicia Rodríguez Barbero, Carmelo Bernabéu y sus respectivos equipos, por su ayuda y su infinita paciencia.

A los profesores y becarios de los Departamentos de Bioquímica y Biología Molecular, de Microbiología y Genética y de Fisiología y Farmacología de la Universidad de Salamanca.

A mis compañeros de muchos años: a Ari, a Celia, a Fernando, a Carmen, a Javi.

A la vieja guardia, mes grognards, mis hermanos de sangre. Siempre ahí, pase lo que pase, caiga quien caiga.

A mis padres, Juan Antonio y Concha, y a mi hermana, María. Sobran los motivos.

Y a Carmen. 



\section{Nota Preliminar ${ }^{1}$}

Este trabajo ha sido realizado durante el disfrute de una beca predoctoral del programa de Formación de Profesorado Universitario (FPU), del Ministerio de Ciencia e Innovación (AP20046065; periodo 2005-2009)

La financiación de la presente Tesis Doctoral ha sido posible gracias a las subvenciones asignadas por los siguientes proyectos

Bases moleculares de la interacción virus-célula de virus respiratorios: estudio de la fusión de membranas en paramixovirus humanos y en paramixovirus animales modelo de enfermedades víricas humanas. FIS PI021848

Departamento de Bioquímica y Biología Molecular, Universidad de Salamanca.

2003-2005

Responsable: Enrique Villar Ledesma.

Mecanismos moleculares implicados en la interacción virus-célula hospedadora. El virus de la enfermedad de Newcastle (NDV) como virus respiratorio modelo y como vector de expresión de proteínas foráneas implicadas en procesos patológicos. FIS PI051796

Departamento de Bioquímica y Biología Molecular, Universidad de Salamanca.

2006-2008

Responsable: Enrique Villar Ledesma.

Bases moleculares de los estadios tempranos de la interacción virus-célula. Procesos implicados en el reconocimiento celular y en la entrada den el citoplasma celular. Junta de Castilla y León. SA009A08

Departamento de Bioquímica y Biología Molecular, Universidad de Salamanca. 2008-2010

Responsable: $\mathrm{M}^{\mathrm{a}}$ Isabel Muñoz Barroso

Utilización del virus de la enfermedad de Newcastle (NDV) como herramienta molecular para el desarrollo de virus recombinantes con capacidad oncolítica. Junta de Castilla y León. SAN/1817/2008

Departamento de Bioquímica y Biología Molecular, Universidad de Salamanca. 2008

Responsable: Enrique Villar Ledesma.

El virus de la enfermedad de Newcastle, herramienta molecular para el estudio de la interacción virus-célula y de la aplicación de virus recombinantes que expresan proteínas implicadas en cáncer y otras patologías. FIS PI081813

Departamento de Bioquímica y Biología Molecular, Universidad de Salamanca.

2009-2011

Responsable: Enrique Villar Ledesma. 



\section{Nota Preliminar ${ }^{2}$}

En el presente trabajo figuran numerosos términos en lengua inglesa. Sin lugar a dudas, la riqueza del vocabulario castellano permitiría que todos estos términos y expresiones fueran traducidos o, en el peor de los casos, sustituidos por vocablos y frases equivalentes en significado en nuestra lengua. Sin embargo el inglés es el idioma internacional usado por la comunidad científica en nuestros días, y en inglés se acuñan y se publican la práctica total de los nuevos avances y descubrimientos que se realizan en las ciencias biomédicas. Por ello, a la hora de redactar esta Tesis hemos considerado más adecuado utilizar directamente en inglés términos para los que no existe una traducción exacta al castellano, así como aquellos que requerirían de expresiones más o menos largas para matizar su exacto significado en nuestra lengua. Ello se ha hecho con el único fin de facilitar la lectura del texto, y siempre con términos cuyo uso en inglés está totalmente asumido por la comunidad científica. Del mismo modo y por los mismos motivos se ha decidido respetar las abreviaturas de terminología científica en su forma inglesa original. 



\begin{tabular}{|c|c|}
\hline $6 \mathrm{HB}$ & Haz de seis hélices. \\
\hline $\mathrm{bp}$ & Pares de bases. \\
\hline BMP & Proteínas morfogénicas del hueso. \\
\hline BSA & Seroalbúmina bovina. \\
\hline CAT & Cloranfenicol acetiltransferasa. \\
\hline $\mathrm{CEF}$ & Fibroblastos de embrión de pollo. \\
\hline Cho & Colesterol. \\
\hline CIP & Fosfatasa alcalina de intestino de cordero. \\
\hline $\mathrm{CMH}$ & Células mesangiales humanas. \\
\hline cDNA & $\begin{array}{l}\text { DNA copia; procedente de RNA tras una } \\
\text { reacción de retrotranscripción. }\end{array}$ \\
\hline $\mathrm{CoV}$ & Coronavirus. \\
\hline $\mathrm{C}-\mathrm{T}$ & Extremo carboxilo terminal. \\
\hline DNA & Ácido desoxirribonucleico. \\
\hline dNTPs & Desoxinucleósidos trifosfato. \\
\hline$E E x C$ & $\begin{array}{l}\text { Fase de lectura del dominio extracelular de } \\
\text { endoglina. }\end{array}$ \\
\hline EExC/F-TMCyt & $\begin{array}{l}\text { Proteína quimérica con el dominio } \\
\text { extracelular de endoglina y los dominios } \\
\text { transmembrana y citoplasmático de la } \\
\text { proteína F de NDV. }\end{array}$ \\
\hline EGFP & Proteína verde fluorescente mejorada. \\
\hline EMCV & Virus de la encefalomiocarditis. \\
\hline Endo & Fase de lectura completa de endoglina. \\
\hline Endo & Endoglina. \\
\hline et al. & (Latín: et alii) « y otros ». \\
\hline $\mathrm{F}$ & Proteína de fusión de los paramixovirus. \\
\hline F3aa & $\begin{array}{l}\text { pNDV con mutación de tres aminoácidos en } \\
\text { el sitio de corte de F/ rNDV derivado de él. }\end{array}$ \\
\hline Fwt & Forma silvestre, no mutada, de la proteína F. \\
\hline FP & Péptido de fusión. \\
\hline$g$ & Aceleración debida a la fuerza de gravedad. \\
\hline G & Glicoproteína de los paramixovirus. \\
\hline GE & Secuencia de final de gen. \\
\hline
\end{tabular}


GFP

GM-CSF

GS

$\mathrm{H}$

HA

HDV

$\mathrm{HeV}$

HIV

HHT

hPIV3

HR

HRP

IBDV

IgG

IL

i.e.

IF

IFN

IS

$\mathrm{kb}$

$\mathrm{kDa}$

L

m.o.i.

mRFP

M

$\mathrm{mAb}$

MCS

$\mathrm{MuV}$

$\mathrm{MeV}$

MVA-T7

NDV
Proteína verde fluorescente.

Factor estimulante de las colonias de macrófagos/granulocitos.

Secuencia de inicio de gen.

Hemaglutinina de los paramixovirus,

Hemaglutinina del virus de la gripe.

Virus de la hepatitis delta.

Virus Hendra.

Virus de la inmunodeficiencia humana.

Telangiectasia hemorrágica hereditaria.

Virus parainfluenza humano 3.

Heptada repetida.

Peroxidasa de rábano.

Virus de la enfermedad infecciosa de la bursa.

Inmunoglobulina $\mathrm{G}$.

Interleucina.

(Latín: id est) « es decir ».

Inmunofluorescencia.

Interferón.

Secuencia intergénica.

Kilobase.

Kilodalton.

Subunidad catalítica de la polimerasa de los paramixovirus

Multiplicidad de infección.

Proteína roja fluorescente monomérica.

Proteína de la matriz.

Anticuerpo monoclonal.

Sitio de clonación múltiple.

Virus de las paperas.

Virus del sarampión.

Virus vaccinia Ankara modificado que expresa la polimerasa $\mathrm{T} 7$.

Virus de la enfermedad de Newcastle. 


\begin{tabular}{|c|c|}
\hline NP & Nucleoproteína de los paramixovirus. \\
\hline $\mathrm{N}-\mathrm{T}$ & Extremo amino terminal. \\
\hline ORF & Fase de lectura abierta. \\
\hline PAGE & Electroforesis en gel de poliacrilamida. \\
\hline $\mathrm{P}$ & Fosfoproteína de los paramixovirus. \\
\hline $\mathrm{pAb}$ & Anticuerpo policlonal. \\
\hline PBS & Solución amortiguadora de fosfatos. \\
\hline $\mathrm{PC}$ & Fosfatidil colina. \\
\hline PCR & Reacción en cadena de la polimerasa. \\
\hline $\mathrm{PE}$ & Fosfatidil etanolamina. \\
\hline pfu & Unidades formadoras de placa. \\
\hline p.i. & Postinfección. \\
\hline PIV5 & Virus parainfluenza 5. \\
\hline pNDV & $\begin{array}{l}\text { Plásmido con el cDNA antigenómico } \\
\text { completo del NDV. }\end{array}$ \\
\hline PolI & RNA polimerasa I. \\
\hline RGD & Motivo arginina-glicina-aspartato. \\
\hline RNA & Ácido ribonucleico. \\
\hline $\mathrm{RNA}(+)$ & $\begin{array}{l}\text { Cadena de RNA de polaridad positiva, con } \\
\text { significado traduccional. }\end{array}$ \\
\hline RNA(-) & $\begin{array}{l}\text { Cadena de RNA de polaridad negativa, } \\
\text { complementaria a la que posee significado } \\
\text { traduccional. }\end{array}$ \\
\hline RNP & Ribonucleoproteína. \\
\hline rNDV & $\begin{array}{l}\text { Virus de la enfermedad de Newcastle } \\
\text { recombinante. }\end{array}$ \\
\hline $\mathrm{rpm}$ & Revoluciones por minuto. \\
\hline RT & Reacción de retrotranscripción. \\
\hline RSV & Virus respiratorio sincitial. \\
\hline RV & Virus de la rabia. \\
\hline SARS & Síndrome respiratorio agudo grave. \\
\hline $\mathrm{SD}$ & Desviación estándar. \\
\hline sEng & Endoglina soluble. \\
\hline $\mathrm{SeV}$ & Virus Sendai. \\
\hline
\end{tabular}


SIV

SPF

TAA

TGF- $\beta$

TNF- $\alpha$

UTR

VSMC

VSV

WKY
Virus de la inmunodeficiencia de simios.

Libre de patógenos específicos.

Antígeno asociado a tumor.

Factor de crecimiento transformante beta.

Factor de necrosis tumoral alfa.

Región no traducida.

Células de músculo liso vascular.

Virus de la estomatitis vesicular.

Rata de la raza Wistar-Kyoto. 


ÍNDICE 


\section{1.- INTRODUCCIÓN}

1.1.- LOS PARAMIXOVIRUS ......................................................................... 3

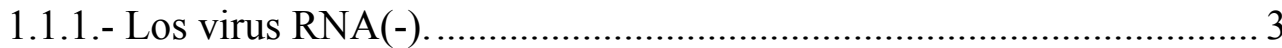

1.1.2.- La familia Paramyxoviridae .............................................................. 4

1.2.- EL VIRUS DE LA ENFERMEDAD DE NEWCASTLE (NDV) .................. 7

1.2.1.- La enfermedad de Newcastle .............................................................. 7

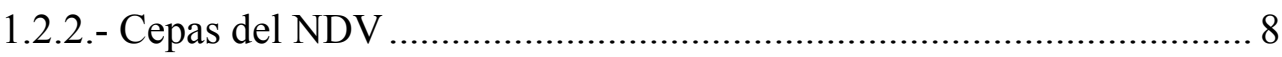

1.2.3.- Morfología y estructura del NDV ...................................................... 9

1.2.3.1.- La nucleocápsida .................................................................. 9

1.2.3.2.- Estructura genómica del NDV ............................................... 11

1.2.3.3.- Edición del gen P. Las proteínas $V y$ W ................................ 12

1.2.3.4.- La membrana externa ............................................................. 13

1.2.4.- Ciclo biológico del NDV ................................................................. 14

1.2.4.1.- Adsorción y entrada en la célula.......................................... 16

1.2.4.2.- Transcripción primaria ........................................................... 17

1.2.4.3.- Replicación del genoma .......................................................... 18

1.2.4.4.- Ensamblaje y liberación de los viriones ................................. 20

1.3.- LA PROTEÍNA DE FUSIÓN DEL NDV (F)............................................. 21

1.3.1.- Las proteínas de fusión víricas clase I. La horquilla helicoidal........ 23

1.3.2.- Estructuras atómicas de la proteína $\mathrm{F}$................................................ 25

1.3.3.- Mecanismo de la fusión de membranas mediada por

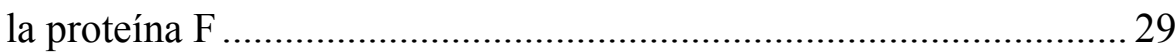

1.3.4.- Regulación de la fusión. La actividad promotora de $\mathrm{HN}$.................... 30

1.3.5.- La proteína F y la virulencia del NDV ............................................... 33

1.4.- LA GENÉTICA INVERSA Y LA VIROLOGÍA MOLECULAR..................34

1.4.1.- Desarrollo de la genética inversa en virus RNA(-)............................ 35

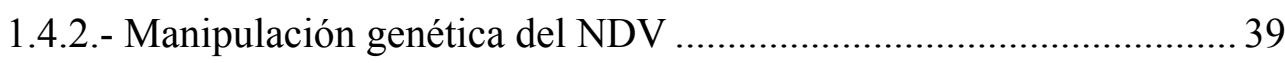

1.4.2.1.- Estudio de los factores de virulencia y propagación del $N D V$........................................................... 40 
1.4.2.2.- Estudios del NDV como vector de vacunación ..................... 44

1.4.2.3.- Estudios del NDV como agente antitumoral ....................... 47

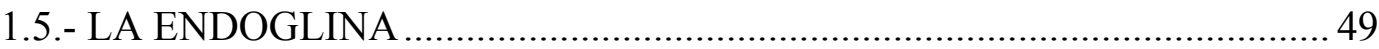

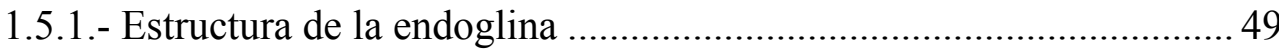

1.5.2.- Importancia fisiológica y fisiopatológica ....................................... 50

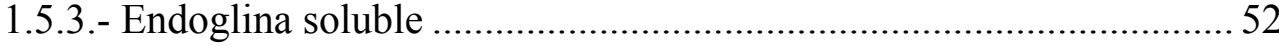

2.- OBJETO DEL PRESENTE TRABAJO....................... 55

3.- MATERIAL Y MÉTODOS ........................................61 61

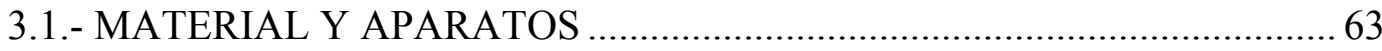

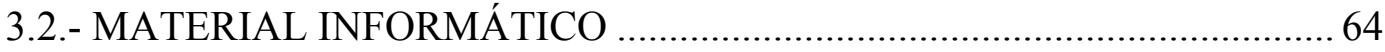

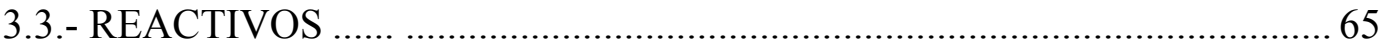

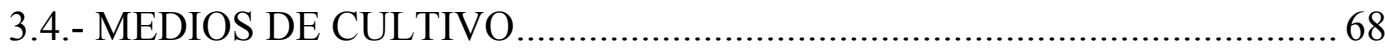

3.4.1.- Medios y soluciones para cultivo celular.......................................... 68

3.4.2.- Medios de cultivo para el crecimiento de bacterias ........................... 68

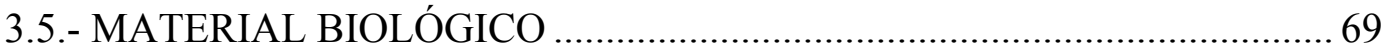

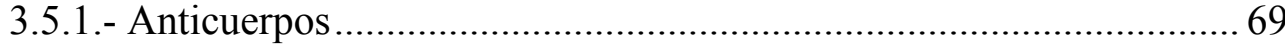

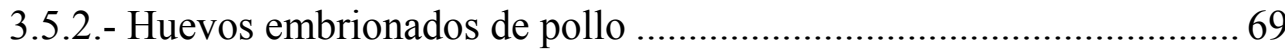

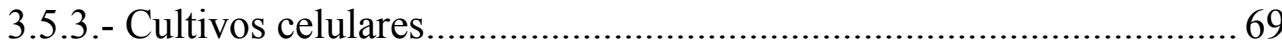

3.5.3.1.- Fibroblastos de embrión de pollo (CEF),

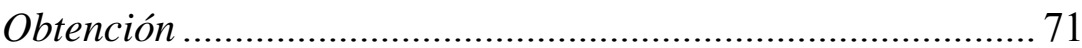

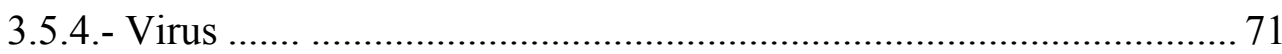

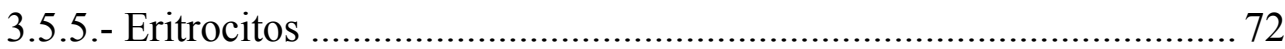

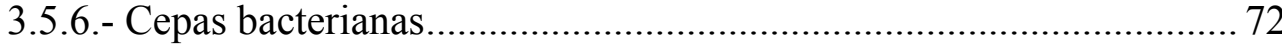

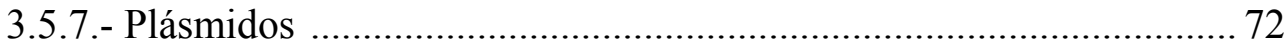

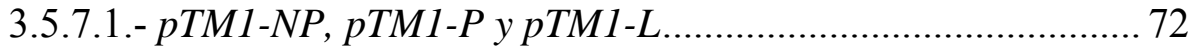

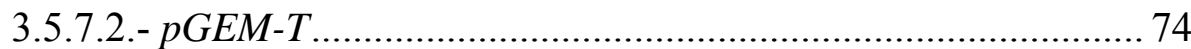

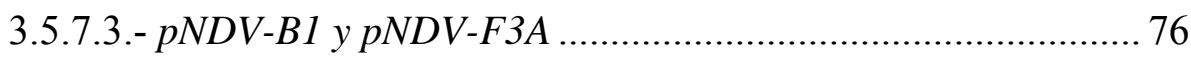

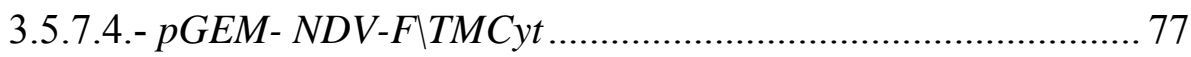

3.5.7.5.- pCMV5-EndoL .............................................................. 78 


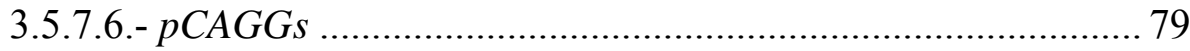

3.6.- TÉCNICAS DE MANIPULACIÓN DEL DNA ............................................ 80

3.6.1.- Aislamiento del DNA plasmídico de E.coli ........................................ 80

3.6.2.- Purificación de plásmidos en gradiente de cloruro de cesio............. 82

3.6.3.- Determinación de la concentración de ácidos nucleicos .................. 83

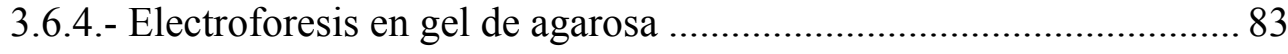

3.6.5.- Digestión con endonucleasas de restricción .................................... 84

3.6.6.- Tratamiento con fosfatasa alcalina (CIP)....................................... 84

3.6.7.- Extracción y purificación de DNA desde geles de agarosa .............. 85

3.6.8.- Diseño de oligonucleótidos para la reacción en cadena

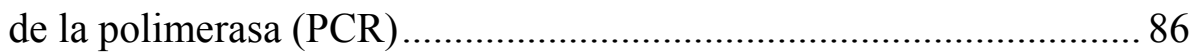

3.6.8.1.- Clonación de la ORF de la endoglina

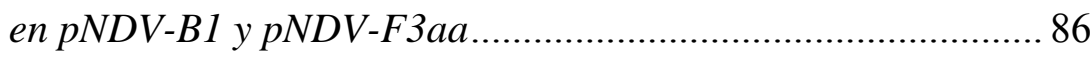

3.6.8.2.- Clonación de las ORF de HN y F en pCAGGs .................... 89

3.6.9.- Reacción en cadena de la polimerasa (PCR) .................................. 89

3.6.10.- Purificación del producto de la PCR .............................................. 90

3.6.11.- Construcción de plásmidos recombinantes..................................... 91

3.6.12.- Clonación de productos de PCR en el vector pGEM-T .................. 91

3.6.13.- Transformación de E. coli DH5 a.................................................. 92

3.6.14.- Selección de clones por PCR sobre colonias .................................. 93

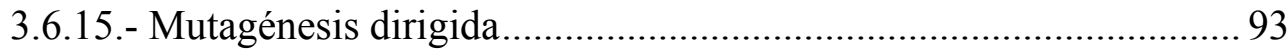

3.6.16.- Extracción de RNA...................................................................... 95

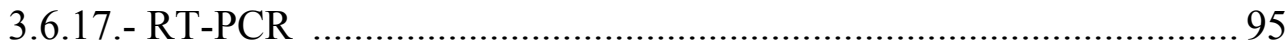

3.6.18.- Secuenciación del DNA................................................................ 97

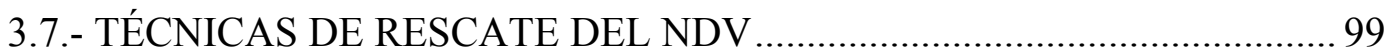

3.7.1.- Infección con MVA-T7 de células en cultivo.................................. 99

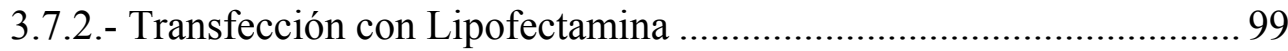

3.7.3.- Cocultivo con fibroblastos de embriones de pollo ........................ 100

3.7.4.- Infección de huevos embrionados .................................................. 101

3.7.5.- Extracción del líquido alantoideo .................................................. 102

3.7.6.- Purificación de NDV recombinante (rNDV) ................................. 102

3.8.- TÉCNICAS DE DETECCIÓN DE PROTEÍNAS ...................................... 103

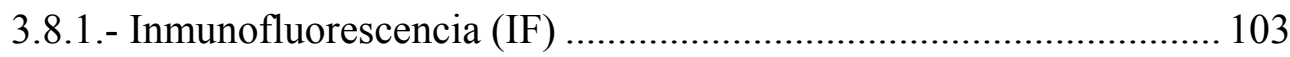

3.8.1.1.- Infección de células en cultivo con rNDV para IF............. 103 
3.8.1.2.- Transfección de células HeLa para IF 103

3.8.1.3.- Fijación de las células e incubación con anticuerpos 103

3.8.1.4.- Titulación del NDV. 104

3.8.2.- Obtención de extractos proteicos ..................................................... 104

3.8.3.- Valoración de proteínas totales....................................................... 105

3.8.4.- Electroforesis en gel de poliacrilamida en presencia de SDS (SDS-PAGE) ................................................... 105

3.8.5.- Tinción de geles de poliacrilamida con azul de Coomassie ........... 106

3.8.5.- Transferencia electroforética de proteínas

(Western blot)

3.8.6.- Cuantificación de la expresión de la proteína $\mathrm{F}$ en la superficie celular por citometría de flujo 108

3.9.- OTRAS TÉCNICAS 109

3.9.1.- Ensayo de hemaglutinación 109

3.9.2.- Valoración de la actividad fusogénica mediante el método de los sincitios

3.9.3.- Ensayos de fusión por transferencia de sonda

3.9.3.1.- Marcaje de eritrocitos humanos con calceína y R18

3.9.3.2.- Procedimiento experimental y cuantificación de los resultados

\section{4.- RESULTADOS Y DISCUSIÓN}

\section{1.- ESTUDIO DEL NDV COMO VECTOR DE EXPRESIÓN}

DE L-ENDOGLINA HUMANA

4.1.1.- Construcción de los plásmidos pNDV-Endo y

pNDV-EExC/F-TMCyt.

4.1.1.1.- Amplificación de las secuencias Endo y EExC por PCR... 120

4.1.1.2.- Clonación de Endo y EExC en pGEM-T

4.1.1.3.- Clonación de EExC en pGEM-NDV-F/TMCyt

4.1.1.4.- Clonación de Endo y EExC|F-TMCyt en pNDV-B1 


\subsubsection{5.- Secuenciación de pNDV-Endo y}

pNDV-EExC/F-TMCyt

4.1.2.- Rescate de los virus recombinantes rNDV-Endo y rNDV-EExC/F-TMCyt

4.1.3.- Determinación de la expresión de endoglina en células infectadas

4.1.4.- Determinación de la incorporación de endoglina a

la envoltura de los viriones recombinantes 136

4.1.5.- Infección de células mesangiales con rNDV-F3aa-Endo 138

4.1.5.1.- Infectividad del NDV en células mesangiales

y niveles de expresión de endoglina.

4.1.5.2.- Evaluación temporal de la expresión de endoglina en cultivos primarios de células mesangiales

4.1.5.3.- Síntesis y acumulación de proteínas de la matriz extracelular por células infectadas con rNDV-Endo 140

4.1.6.- Relevancia de los resultados obtenidos

\section{2.- ESTUDIO MUTACIONAL DE LA PROTEÍNA}

DE FUSIÓN DEL NDV 149

4.2.1.- Clonación de las ORF de las proteínas HN y F del NDV/Hitchner B1. Mutagénesis de F. 151

4.2.1.1.- Amplificación de las secuencias $H N$ y $F$ por PCR 151

4.2.1.2.- Clonación de $F$ y $H N$ en pGEM-T 152

4.2.1.3.- Mutagénesis dirigida de la proteína $F$ 152

4.2.1.4.- Clonación de $F$ y $H N$ en pCAGGs 156

4.2.2.- Análisis de los mutantes de la proteína F del NDV 157

4.2.2.1.- Determinación de la expresión de las proteínas mutantes en la superficie celular

4.2.2.2.- Efecto de las mutaciones de la proteína $\mathrm{F}$ en la fusión célula-célula

4.2.2.3.- Actividad fusogénica de los mutantes

N211A, I463A e I463F en ausencia de la proteína HN 166

4.2.2.4.- Efecto de la tempertatura en la actividad 


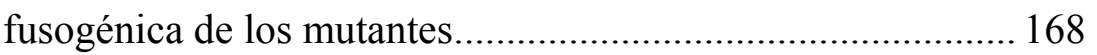

4.2.3.- Relevancia de los resultados obtenidos ....................................... 170

5.- CONCLUSIONES ....................................................... 179

6.- BIBLIOGRAFÍA ................................................................. 185

ANEXO I

(El código genético, nomenclatura de aminoácidos) .... 207

ANEXO II

(Índice de tablas y figuras) ................................................... 211 


$-2-$ 


\section{1.- LOS PARAMIXOVIRUS}

\subsection{1.- LOS VIRUS RNA (-)}

Los virus con genoma RNA de polaridad negativa, o RNA(-), complementario al que puede traducirse, se clasifican en siete familias: Rhabdo-, Paramyxo-, Filo-, Borna-, Orthomyхо-, Bunya- у Arenaviridae. Entre ellas, las cuatro primeras se caracterizan por poseer genomas no segmentados, y se engloban en el orden Mononegavirales; mientras que las otras tres lo tienen dividido en entre seis y ocho, tres o dos segmentos respectivamente. Todos los virus RNA(-) tienen una nucleocápsida con simetría helicoidal, formada por el genoma y proteínas asociadas, que se encuentra rodeada por una membrana proteolipídica procedente de la célula hospedadora. Este grupo tan amplio comprende patógenos humanos como el virus respiratorio sincitial (RSV), el virus parainfluenza humano, los virus de la gripe y dos de los más virulentos patógenos del ser humano, los virus Ebola y Marburg.

Tabla 1.1. Las familias de los virus RNA(-)

Tomado de la página web del Comité Internacional de Taxonomía de Virus: http://www.ictvonline.org (03/2009).

\begin{tabular}{|c|c|c|}
\hline & Familias & Virus representativos \\
\hline \multirow{4}{*}{ 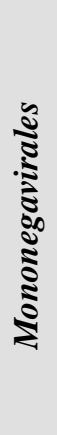 } & Bornaviridae & Virus de la enfermedad de Borna. \\
\hline & Filoviridae & Virus Marburg, Virus Ebola Zaire. \\
\hline & Paramyxoviridae & $\begin{array}{l}\text { Virus del sarampión, virus de las paperas, virus Sendai, virus parainfluenza } \\
\text { humano, virus de la enfermedad de Newcastle (NDV), virus de la peste } \\
\text { bovina, virus respiratorio sincitial. }\end{array}$ \\
\hline & Rhabdoviridae & Virus de la rabia, virus de la estomatitis vesicular (VSV) \\
\hline \multicolumn{2}{|c|}{ Orthomyxoviridae } & Virus de la gripe A, B y C. \\
\hline \multicolumn{2}{|r|}{ Bunyaviridae } & Virus bunyamwera, virus de la fiebre del valle del Rift \\
\hline \multicolumn{2}{|r|}{ Arenaviridae } & Virus de la hepatitis delta, virus de la coriomeningitis linfocítica \\
\hline
\end{tabular}


También son RNA(-) virus de gran importancia económica por afectar masivamente a explotaciones avícolas, como el virus de la enfermedad de Newcastle en el que se centra este trabajo, y ganaderas, como el virus de la peste bovina.

\subsection{2.- LA FAMILIA PARAMYXOVIRIDAE}

Los paramixovirus son una de las siete familias de virus RNA(-), y una de las cuatro que tienen el genoma no segmentado y que constituyen el orden Mononegavirales. Su interés radica tanto en que causan una amplia variedad de patologías en el hombre y otros animales como en ser excelentes modelos para el estudio de la biología de los virus en general y de los RNA(-) en particular.

La familia Paramyxoviridae (Lamb y Parks, 2007) agrupa virus con membrana que poseen una nucleocápsida helicoidal rodeada por una membrana lipoproteica. En la nucleocápsida se encuentra el genoma, formado por una molécula de RNA monocatenario de polaridad negativa, y una serie de proteínas asociadas al mismo, entre ellas la polimerasa vírica. El RNA genómico sirve de molde tanto para la síntesis de RNA mensajero como para la del antigenoma, de polaridad positiva, que a su vez será molde para la replicación de nuevas moléculas de RNA genómico. La envoltura que rodea la nucleocápsida está formada por una membrana lipídica, derivada de la membrana plasmática de la célula hospedadora, en la que se insertan las glicoproteínas víricas con aspecto de espículas (Rott, 1979). En la zona interna de la envoltura se localiza otra proteína, denominada $\mathrm{M}$ o de la matriz, constituyendo un armazón que establece contacto tanto con la envoltura como con la nucleocápsida (Shimizu e Isida, 1975; García- Sastre et al., 1989; Galinsky y Wechsler, 1991).

Las características compartidas por los ortomixovirus y los paramixovirus, como la patogenicidad a nivel del tracto respiratorio, aglutinación de eritrocitos, existencia en ambos grupos de proteínas con actividad sialidásica y facilidad de cultivo en embriones de pollo, llevó a Andrewes et al. (1955) a proponer el término mixovirus (del griego myха; "mucus) como denominación conjunta para ambos grupos, que incluirían los virus de la gripe A, B y C, el virus de las paperas y el virus de la enfermedad de Newcastle (NDV). Las diferencias de tamaño en las nucleocápsidas llevaron a Waterson (1962) a separar a los mixovirus en las dos familias que se mantienen actualmente

(Paramyxoviridae y Orthomyxoviridae). Actualmente, el Comité Internacional de Taxonomía de Virus divide la familia Paramyxoviridae en dos subfamilias, 
Paramyxovirinae y Pneumovirinae, la primera con cinco géneros, Respirovirus, Morbilivirus, Rubulavirus, Henipavirus y Avulavirus; y la segunda con dos géneros Pneumovirus y Metapneumovirus (Tabla 1.2). La clasificación se basa en criterios morfológicos, organización del genoma, relación de secuencias de las proteínas codificadas y actividades biológicas de dichas proteínas.

\section{Subfamilia Paramyxovirinae.}

Los virus pertenecientes a esta subfamilia poseen dos glicoproteínas transmembranales. Una de ellas es la encargada de la unión del virus a receptores específicos de la célula huésped [G (glicoproteína), H (hemaglutinina) o HN (hemaglutinina-neuraminidasa), dependiendo del género del virus]. La otra glicoproteína lleva a cabo la fusión de membranas $(\mathrm{F})$.

La subfamilia Paramyxovirinae fue dividida inicialmente en tres géneros (Respirovirus, Morbilivirus y Rubulavirus), de acuerdo con la existencia o no de actividad sialidásica y la longitud de las secuencias intergénicas. Esta clasificación separaba al género Morbilivirus del resto por carecer de actividad sialidásica, aunque en 1997 Langedijk et al. la describieron para algunos miembros de este grupo. En los Respirovirus, las secuencias intergénicas tienen una longitud constante de tres nucleótidos, a diferencia de lo que ocurre con el género Rubulavirus, en el cual la longitud de estas secuencias puede variar desde 1 a 47 nucleótidos.

El virus de la enfermedad de Newcastle y otros paramixovirus de aves fueron en principio incluidos en el género Rubulavirus, debido a las características de sus regiones intergénicas conservadas y a la ausencia de fase de lectura abierta para la proteína $\mathrm{C}$. Sin embargo, en la organización del gen de la proteína P del NDV (ver Figura $1.1 \mathrm{y}$ apartado 1.2.3) y en su perfil de edición del mRNA se parecen más a los géneros Morbilivirus y Respirovirus, por lo que se llegó a la conclusión de que se requerían más consideraciones sobre la taxonomía de este tipo de virus. Tras la comparación de las secuencias genómicas completas del NDV y otros paramixovirus (de Leeuw y Peeters, 1999), del análisis de las proteínas $\mathrm{P}$ (Locke et al., 2000), M (Seal et al., 2000), y NP (Seal et al., 2002), se decidió crear para este grupo el género Avulavirus (Mayo, 2002).

Por último, el género Henipavirus (Chua et al., 2000) se creó tras la aparición de dos nuevos virus: Hendra $(\mathrm{HeV})$, agente etiológico de una epizootia respiratoria sucedida en Australia en 1994 que afectó principalmente al ganado equino y produjo la 
muerte de una persona; y el virus Nipah, causante de una epidemia de encefalitis febril en Malasia en 1998 que también produjo muertes humanas.

\section{Subfamilia Pneumovirinae.}

Los miembros de esta subfamilia se distinguen morfológicamente de los Paramyxovirinae por contener nucleocápsidas más estrechas. Sólo poseen una proteína en la membrana $(\mathrm{G})$, y carecen de las actividades sialidásica y hemaglutinante (Richman et al, 1971; Kingsbury et al, 1985). También difieren en aspectos del RNA vírico y en estructura de proteínas. Comprende dos géneros, Pneumovirus y Metapneumovirus.

En el Tabla 1.2 se indican algunos ejemplos de los virus pertenecientes a cada uno de los géneros mencionados dentro de la familia Paramyxoviridae.

\begin{tabular}{|c|c|c|c|}
\hline \multicolumn{4}{|c|}{ Tabla 1.2. Clasificación de la familia Paramyxoviridae } \\
\hline \multirow{7}{*}{ 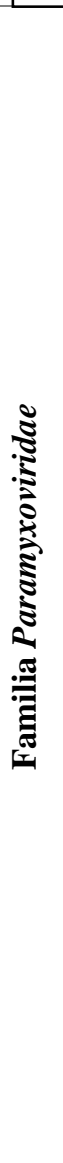 } & \multirow{5}{*}{$\begin{array}{l}\text { Subfamilia } \\
\text { Paramyxovirinae }\end{array}$} & Género Respirovirus & $\begin{array}{l}\text { Virus Sendai (SeV) } \\
\text { Virus parainfluenza humano (hPIV) tipos } 1 \text { y } 3 \\
\text { Virus parainfluenza bovino (bPIV) tipo } 3\end{array}$ \\
\hline & & Género Rubulavirus & $\begin{array}{l}\text { Virus parainfluenza } 5 \text { (PIV5) } \\
\text { Virus de las paperas (MuV) } \\
\text { Virus parainfluenza humano (hPIV) tipos 2, 4a y } \\
4 \mathrm{~b}\end{array}$ \\
\hline & & $\begin{array}{l}\text { Género } \\
\text { Morbillivirus }\end{array}$ & $\begin{array}{l}\text { Virus del sarampión (MeV) } \\
\text { Virus del moquillo canino (CDV) } \\
\text { Virus de la peste bovina }\end{array}$ \\
\hline & & Género Avulavirus & $\begin{array}{l}\text { Virus de la enfermedad de Newcastle } \\
\text { (NDV) }\end{array}$ \\
\hline & & Género Henipavirus & $\begin{array}{l}\text { Virus Hendra }(\mathrm{HeV}) \\
\text { Virus Nipah }(\mathrm{NiV})\end{array}$ \\
\hline & \multirow{2}{*}{$\begin{array}{l}\text { Subfamilia } \\
\text { Pneumovirinae }\end{array}$} & $\begin{array}{l}\text { Género } \\
\text { Pneumovirus }\end{array}$ & $\begin{array}{l}\text { Virus respiratorio sincitial humano (hRSV) } \\
\text { Virus respiratorio sincitial bovino (bRSV) } \\
\text { Virus de la neumonía del ratón }\end{array}$ \\
\hline & & $\begin{array}{l}\text { Género } \\
\text { Metapneumovirus }\end{array}$ & $\begin{array}{l}\text { Metaneumovirus humano (hMPV) } \\
\text { Metaneumovirus aviar tipos A, B y C }\end{array}$ \\
\hline
\end{tabular}

Evolutivamente, en principio se propuso la procedencia de ortomixovirus y paramixovirus de un ancestro común, en base a la similitud de sus propiedades biológicas (Kingsbury, 1985) y a la homología de secuencias de las proteínas víricas 
(Blumberg et al., 1985). Hoy se considera que los paramixovirus están más relacionados con Rhabdoviridae, grupo que incluye los virus de la rabia (RV) y de la estomatitis vesicular (VSV) y con el que poseen grandes similitudes en organización y expresión genómica (Yusoff et al., 1987). También se han llevado a cabo estudios acerca de la evolución de las distintas cepas de NDV (Toyoda et al, 1989; Seal et al, 1998), que indican que la misma ocurre principalmente por acumulación de mutaciones puntuales más que por recombinación del genoma.

\section{2.-EL VIRUS DE LA ENFERMEDAD DE NEWCASTLE (NDV)}

\subsection{1.- LA ENFERMEDAD DE NEWCASTLE.}

La enfermedad de Newcastle es un proceso infeccioso causado por el virus que lleva su nombre (NDV), o paramixovirus aviar tipo 1, que afecta a aves silvestres y domésticas causando alteraciones en el sistema respiratorio, nervioso o digestivo. En el caso de las cepas más virulentas puede incluso provocar el $90 \%$ de mortalidad entre los animales infectados (Chang, 1975). La enfermedad causa graves pérdidas económicas al provocar la muerte de aves de corral o, cuando menos, una drástica reducción de la puesta. Las infecciones en el hombre son resultado de accidentes de laboratorio, vacunación o manipulación de pollos enfermos, y sus síntomas son ligeros y se reducen a síntomas gripales o conjuntivitis (Rott y Klenk, 1988). El virus apenas puede multiplicarse en células humanas sanas, sin embargo se multiplica 10.000 veces más rápido en células tumorales, probablemente debido a la disrupción del sistema del interferón al que es especialmente sensible: el propio daño que produce en ellas y la potenciación del sistema inmune como consecuencia de su alta actividad han fijado la atención en el NDV como posible agente antitumoral, aspecto que será tratado posteriormente en el apartado 1.4.2.3.

Históricamente, la primera descripción de la enfermedad de Newcastle (Kraveneld, 1926), tiene lugar en la isla de Java. Sin embargo, Doyle (1927) la citó cerca de Newcastle-upon-Tyne, en Inglaterra, de donde toma su nombre, aunque hay informes de posibles epizootias en Corea durante 1924 y en Europa Central antes de 1926 (Alexander, 1997). En la actualidad, la enfermedad de Newcastle se encuentra 
distribuida por todo el mundo, por lo que la vacunación de las aves de corral contra la misma es hoy en día una práctica habitual.

En lo referente a las vías de propagación, se han descrito varias: a través de pájaros enfermos procedentes de regiones donde la enfermedad es endémica; por el transporte de pollos portadores a otras regiones; por la diseminación aérea del virus o por mamíferos que sufren infecciones asintomáticas, incluido el hombre (Lancaster y Alexander, 1975).

\subsection{2.- CEPAS DEL NDV.}

El término "cepa" aplicado al NDV se utiliza para designar una linea de virus caracterizada y estable. Se han descrito varias cepas de NDV con marcadas diferencias en cuanto a su capacidad para producir enfermedad y muerte en pollos. Hanson y Brandly (1955) las agruparon arbitrariamente en tres grupos según su patogenicidad en embriones de pollo:

- Cepas velogénicas, que producen la muerte del embrión entre 40 y 60 horas tras la inyección de la dosis letal mínima (tiempo medio de muerte en huevos).

- Cepas mesogénicas: tiempo medio de muerte en huevos entre 60 y 90 horas.

- Cepas lentogénicas: aquellas que tardan más de 90 horas en provocar efectos letales.

Pese a su arbitrariedad esta clasificación sigue en uso actualmente, por resultar muy útil en la distición de cepas.

Hanson (1972), tomando en consideración los síntomas que produce la enfermedad, clasificó las cepas del NDV en otros cuatro grupos:

- Formas "Doyle" o velogénicas-viscerotrópicas, que engloban las cepas extremadamente letales en pollos y que producen lesiones hemorrágicas en el intestino.

- Formas “Beach” o velogénicas-neumotrópicas, que provocan una mortalidad en pollos también elevada, con aparición de transtornos nerviosos y respiratorios pero sin lesiones intestinales.

- Formas “Beaudette”, equivalentes a las mesogénicas. Provocan en pollos síntomas respiratorios y ocasionalmente nerviosos. Los pollos jóvenes pueden morir, pero en general la mortalidad es muy baja. 
- Formas "Hitchner", que engloban las cepas lentogénicas, provocando infecciones suaves o inaparentes. A este grupo pertenecen los virus empleados en el presente trabajo, tal y como se describe en el apartado de métodos.

\subsection{3.- MORFOLOGÍA Y ESTRUCTURA DEL NDV.}

El virus de la enfermedad de Newcastle es un paramixovirus típico que consta de una envoltura membranosa rodeando una nucleocápsida helicoidal. Las partículas víricas son generalmente esféricas con un diámetro de 100 a $200 \mathrm{~nm}$, aunque pueden presentar un alto nivel de pleomorfismo, pudiendo observarse formas de hasta $600 \mathrm{~nm}$ de diámetro. Roberts y Compans (1998) demostraron para el también pleomórfico virus de la gripe que son el tipo celular hospedador y especialmente la integridad de los filamentos del citoesqueleto del mismo los que determinan en última instancia la morfología del virión. Dado que las proteínas de los paramixovirus tambien interaccionan con el citoesqueleto (Sanderson et al, 1995), es posible que lo anteriormente descrito para el virus de la gripe sea aplicable también al NDV.

El virus purificado muestra la siguiente composición química: $67 \%$ de proteínas, 1\% de RNA, 24\% de lípidos y 7\% de glúcidos (Lancaster y Alexander, 1975).

\subsubsection{1.- La Nucleocápsida.}

La nucleocápsida es una estructura helicoidal de giro levógiro, con un diámetro de 17-18 $\mathrm{nm}$ y un hueco interior de 4-5 $\mathrm{nm}$, aunque puede existir en distintos estados morfológicos (Egelman et al., 1989), muy posiblemente en función de las diferentes etapas del ciclo vírico. Esta formada por una molécula de RNA monocatenario de polaridad negativa que constituye el genoma vírico, el cual en ningún momento del ciclo replicativo está aislado: siempre se encuentra asociado a proteínas formando el complejo ribonucleoproteico (RNP), concepto equivalente al de nucleocápsida. El RNA constituye algo más del 9\% de la nucleocápsida (Rott et al, 1963) y su tamaño varía entre 49S y 57S (Lancaster y Alexander, 1975)

Las proteínas que forman parte de la nucleocápsida son (Figura 1.1):

- Proteína NP (“nucleoprotein”). Es la proteína estructural mayoritaria, con 2600 copias por cada molécula de RNA, a la que se une en todo momento, de forma que cada seis nucleótidos del genoma interaccionan con una copia de la NP (Egelman et al, 
1989; Kolakofsky et al, 1998). Tiene un peso molecular de $53 \mathrm{kDa}$ y sus funciones son participar en el proceso de encapsidación interaccionando con la proteína $\mathrm{M}$ y en los de transcripción y replicación colaborando con las proteínas L y P, además de mantener la integridad estructural de la nucleocápsida.

- Proteína L (“large”) o de alto peso molecular. Es la subunidad catalítica de la RNA polimerasa RNA dependiente del virus (Peeples y Bratt, 1982). Su peso molecular es aproximadamente $250 \mathrm{kDa}$ y tan sólo se encuentran entre 30 y 50 copias por nucleocápsida, pues sólo va a precisarse un pequeño número de ellas para la replicación del RNA.

- Proteína P (“phosphoprotein”). Es la segunda proteína más abundante de la nucleocápsida, con 250-300 copias por virión. Se asocia a la proteína L para formar la polimerasa del virus. Tiene un peso molecular de $53 \mathrm{kDa}$ y se encuentra altamente

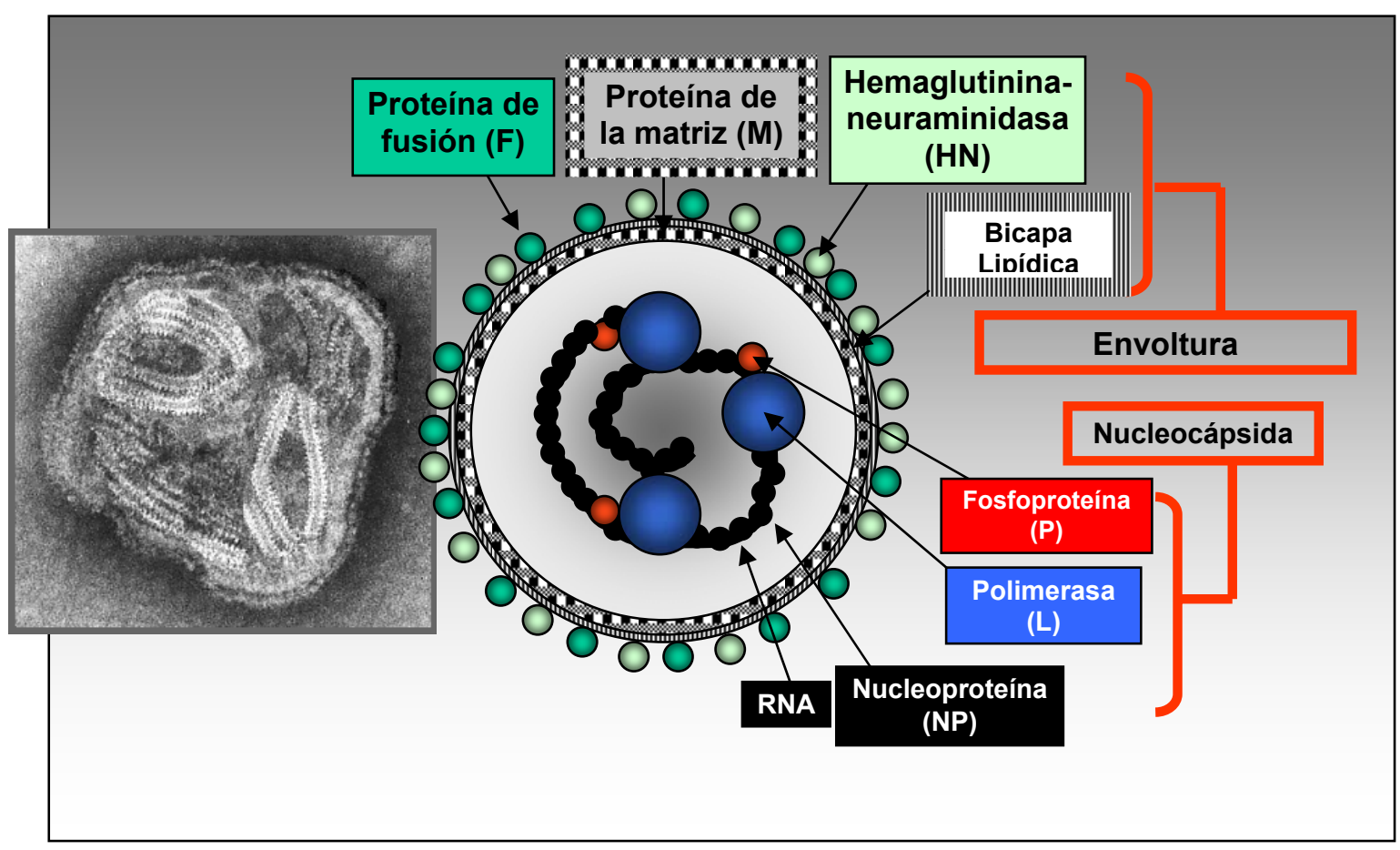

Figura 1.1. Estructura del NDV. Micrografía electrónica de un virión de la cepa Clone 30 (García-Sastre, 1990) y esquema derivado de la misma. 


\subsubsection{2.- Estructura Genómica del NDV.}

La única cadena de RNA monocatenario de polaridad negativa que porta la información genética del NDV contiene un total de 15186 nucleótidos (Krishnamurthy y Samal, 1998; de Leeuw y Peeters, 1999). En los extremos posee dos secuencias extracistrónicas, no codificantes, conocidas como “leader” (en 3') y “trailer” o “-leader" (en 5'). Estas dos secuencias de control, que son esenciales para la transcripción y replicación (Blumberg et al, 1991; Harty y Palese, 1995, Marcos et al., 2005) flanquean los seis genes que codifican las proteínas estructurales del NDV. En los virus RNA(-), por consenso, el término gen se refiere a la secuencia del genoma que codifica un único mRNA, incluso si esa secuencia incluye más de una fase de lectura abierta (ORF) o puede codificar más de una proteína. El orden en que se encuentran los seis genes del NDV, el mismo orden en que los mRNA son transcritos tal y como se describe más adelante, es de suma importancia para el ciclo replicativo del virus, y se muestra en la Figura 1.2. Entre los genes hay secuencias conservadas que indican a la polimerasa vírica el final (GE) y el inicio (GS) de cada ORF, separadas por regiones intergénicas no codificantes (IS) de longitud variable en los paramixovirus. En el NDV son de 1 nucleótido entre NP-P, P-M y M-F; de 31 entre F-HN y de 47 entre HN-L (Krishnamurthy y Samal, 1998). Modificar esta longitud, aumentándola o disminuyéndola, origina virus atenuados o completamente inviables (Yan y Samal, 2008)

Un aspecto de gran importancia en la genética de los paramixovirus es que la mayor parte de los genomas conocidos de los mismos tienen un número de nucleótidos múltiplo de seis. Egelman et al. (1989) sugirieron, basándose en microscopía electrónica de las nucleocápsidas del virus Sendai $(\mathrm{SeV})$, que cada monómero de la proteína NP se asociaba exactamente con seis nucleótidos, lo que llevó a Calain y Roux (1993) a estudiar la eficacia replicativa de minigenomas (ver apartado 1.2.4.3) con distinto número de nucleótidos. La conclusión a la que llegaron, y que acuñaron como "regla del seis", es que el genoma de estos virus debe ser múltiplo de ese número para ser replicado eficientemente. La explicación propuesta para este fenómeno es que sólo si el genoma está completamente recubierto por NP hasta su extremo promotor puede la polimerasa incorporarse al mismo para llevar a cabo su función. Aunque aún no hay evidencias bioquímicas directas de la interacción de NP con seis nucleótidos y aunque el estricto ajuste a la regla del seis sólo se da en ciertos géneros de paramixovirus 
(revisado por Kolakofsky et al, 1998), en el caso del NDV sí demuestra tener una gran importancia (Peeters et al., 2000; Marcos et al., 2005).

\subsubsection{3.- Edición del gen P. Las proteínas $V y$ W.}

En todos los paramixovirus la capacidad codificante del genoma se ve ampliada por el uso de fases de lectura superpuestas en el gen de la proteína P. Este hecho permite, en el caso del NDV, la síntesis de dos proteínas adicionales, $\mathrm{V} \mathrm{y} \mathrm{W}$, originadas por el desplazamiento de la fase de lectura al añadirse nucleótidos adicionales durante la transcripción: por ese desplazamiento se pueden originar proteínas que comparten sus extremos amino-terminales con $\mathrm{P}$ y difieren en los carboxi-terminales. La adición de un nucleótido $\mathrm{G}$ adicional por este mecanismo da lugar a los transcritos de V; si son dos $\mathrm{G}$ se originan los de W. De la proteína $\mathrm{V}$, que en principio sólo se suponía implicada en la regulación de la replicación vírica (Steward et al, 1993), se han descrito recientemente funciones como antagonista del sistema del interferón de la célula hospedadora y como limitante de la apoptosis generada por la infección (Park et al., 2003a; Park et al., 2003b; Huang et al., 2003b; apartado 1.4.2.1). Estas propiedades la convierten en fundamental para explicar la capacidad replicativa de las distintas cepas y su virulencia (Mebatsion et al., 2001), así como en un factor determinante del espectro de posibles hospedadores (Park et al., 2003b). Tradicionalmente se ha considerado V como una proteína no estructural, no obstante puede ser inmunodetectada en viriones purificados de NDV en cantidades proporcionales a las producidas durante la infección (Mebatsion et al., 2001).

Para el NDV se ha establecido que en una infección el 68\% de los transcritos del gen $\mathrm{P} / \mathrm{V} / \mathrm{W}$ corresponden a mRNA de $\mathrm{P}$, un $29 \%$ a mRNA de $\mathrm{V}$ y un $2 \%$ a mRNA de W. De ésta última proteína no se ha encontrado hasta el momento ninguna función (Huang et al., 2003b; Mebatsion et al., 2003). Además se ha propuesto la existencia de otra proteína derivada del gen $\mathrm{P}$, a la que se denominó $\mathrm{X}$, cuyo transcrito se originaría desde un codón de iniciación interno en la posición 120 de la ORF de P y conservado en todas las cepas (Locke et al., 2000). Si bien hay paramixovirus que presentan proteínas de este tipo ( $\mathrm{SeV}$ de hecho tiene hasta siete productos derivados del mismo gen $\mathrm{P}$ ), en el caso del NDV se ha demostrado que la hipotética X no se expresa (Peeters et al., 2004). 


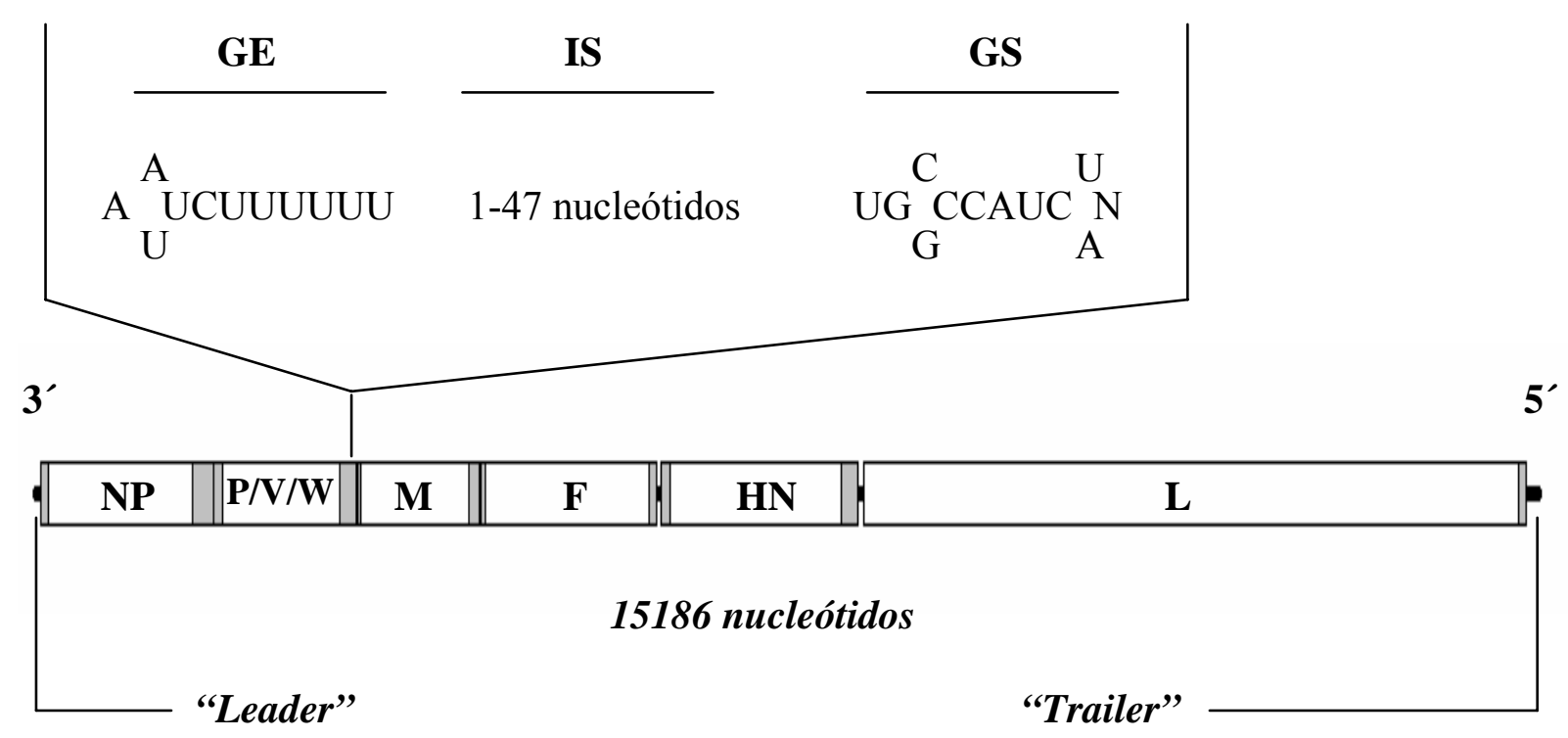

Figura 1.2. Organización del genoma del NDV. Se muestran a escala los distintos genes del NDV. Las zonas blancas son las ORFs y las grises las partes de los transcritos que no se traducirán. También se muestran las secuencias conservadas de final e inicio de la transcripción y la posición de las señales de regulación no transcritas en $5^{\prime}$ y $3^{\prime}$.

\subsubsection{4.- La Membrana Externa.}

La envoltura del virus está formada por una membrana lipoproteica con estructura de bicapa derivada de la membrana plasmática de la célula hospedadora y modificada por la incorporación de las proteínas víricas (Stenback y Durand, 1963). Hay tres tipos de proteínas en la membrana (Figura 1.1); dos de ellas, HN y F, atraviesan la bicapa exponiendo hacia el interior del virión un fragmento de su cadena polipeptídica y hacia el exterior una cabeza globular. Esto les confiere una apariencia de espículas sobre la superficie del virión, las cuales se proyectan unos $8 \mathrm{~nm}$ desde la superficie de la bicapa, tienen entre 1.0 y $1.5 \mathrm{~nm}$ de ancho y están espaciadas unos 5-10 nm (Lancaster y Alexander, 1975).

- La glicoproteína HN (hemaglutinina-neuraminidasa). Glicoproteína transmembrana de tipo II, con el extremo carboxi-terminal extracelular (Schuy et al., 1984.). Se encuentra formando tetrámeros compuestos por dos dímeros. Cada monómero tiene un peso molecular de $74 \mathrm{kDa}$. Es una proteína multifuncional con tres actividades: reconocimiento del receptor del virus (moléculas con ácidos siálicos, glicolípidos o glicoproteínas, de ahí su carácter hemaglutinante), liberación de esos 
mismos receptores (actividad sialidásica/neuraminidásica) y actividad promotora de la fusión inducida por la proteína $\mathrm{F}$. Se han descrito dos sitios de reconocimiento de receptor en la cabeza globular de la proteína HN en el NDV: uno de ellos también presenta la actividad sialidásica y el segundo queda expuesto en la interfase de los dímeros únicamente tras la unión del primero a su ligando. Existe controversia respecto a qué región de la proteína esta implicada en la promoción de la fusión, i.e. en la interacción HN-F: si bien hay consenso con respecto al importante papel del tallo en este proceso, la participación o no de la cabeza globular queda por determinar (Crennell et al., 2000; Bousse et al., 2004; Ferreira et al., 2004a; Zaitsev et al., 2004; Mahon et al., 2008, apartado 1.3.4)

- La glicoproteína F (o de fusión). Glicoproteína transmembrana de tipo I, con el extremo carboxi-terminal intracelular; formada por dos subunidades, $F_{1}$ y $F_{2}$, de pesos moleculares aproximados de 55 y $12 \mathrm{kDa}$ respectivamente. Ambas proceden de un precursor $\mathrm{F}_{0}$ procesado proteolíticamente y unidas entre sí por un puente disulfuro (Iwata et al., 1994). Se encuentra formando homotrímeros y es la proteína encargada dei nducir la fusión entre las membranas vírica y celular. Dada la importancia que tiene la proteína $\mathrm{F}$ en el presente trabajo, más adelante abordaremos con mayor detalle sus características estructurales y funcionales (apartado 1.3).

- La proteína no glicosilada M (o de la matriz). Es la proteína más abundante del virión. Tiene un peso molecular aproximado de $40 \mathrm{kDa}$ y forma un armazón o matriz periférica que recubre internamente la envoltura membranosa, manteniendo la estructura del virión al interactuar tanto con el resto de las proteínas de membrana como con las de la nucleocápsida. Juega un papel fundamental en la liberación de los viriones de la célula infectada.

El componente lipídico de la envoltura, aún derivado del de la membrana plasmática de la célula hospedadora, difiere en sus proporciones del de ésta, lo que indica que durante el proceso de gemación de los viriones se produce una selección de los lípidos celulares de forma que no todos pasan a formar parte de la membrana vírica en las mismas cantidades. Esta selección la realizan las proteínas víricas, que de esta manera no sólo controlan el entorno lipídico en que se encuentran, sino que también actúan sobre un factor que puede modular su actividad, y con ello la infectividad de la progenie vírica (Aloia et al., 1993). Así ha sido demostrado para el virus de la estomatitis vesicular (VSV) (Luan y Glaser, 1994; Luan et al., 1995), cuyas proteína G (única proteína transmembrana) y $\mathrm{M}$ poseen la capacidad de crear dominios en la 
membrana enriquecidos, respectivamente, en ácido fosfatídico y en ácido fosfatídico y fosfatidil-serina. En el NDV, nuestro grupo demostró que las actividades sialidásica y hemaglutinante de la proteína $\mathrm{HN}$ requieren la presencia de fosfolípidos definidos en el entorno, en concreto fosfatidil-etanolamina (Muñoz-Barroso et al., 1997).

\subsection{4.- CICLO BIOLÓGICO DEL NDV.}

En la Figura 1.3 puede verse un resumen de las etapas del ciclo biológico del NDV dentro de la célula hospedadora: unión al receptor, fusión de membranas, síntesis de nuevos viriones (transcripción, traducción y replicación), y gemación. Todos los aspectos del mismo tienen lugar en el citoplasma. En cultivo celular, un ciclo de crecimiento tiene una duración de entre 14-20 horas, pudiendo llegar a las 10 horas en el caso de las cepas más virulentas del NDV (Lamb y Kolakofsky, 2001).

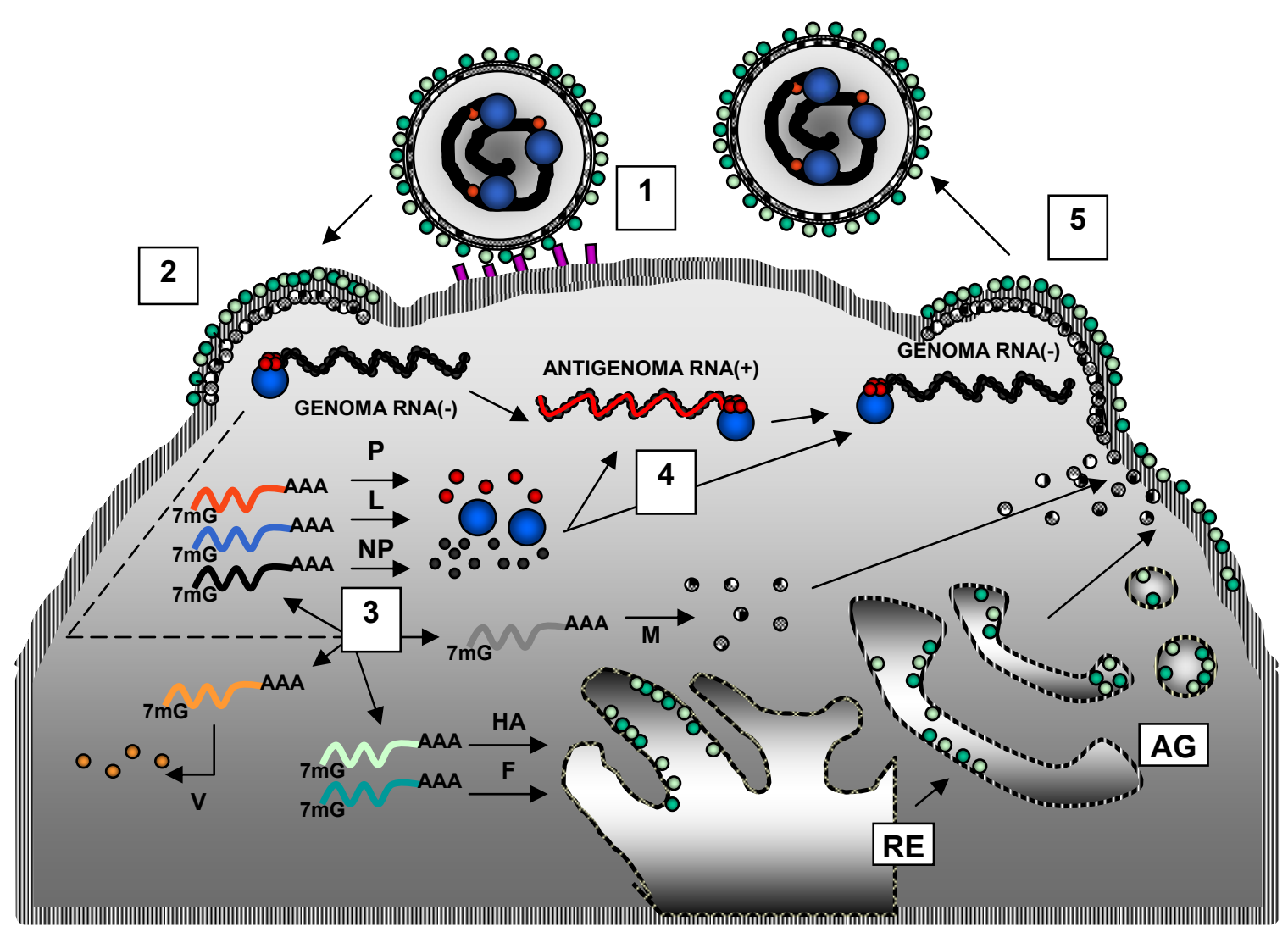

Figura 1.3. Ciclo biológico del NDV. 1.- Adsorción; 2.- Entrada en la célula; 3.- Transcripción primaria; 4.- Replicación del genoma; 5.- Ensamblaje y liberación de los viriones. 


\subsubsection{1.- Adsorción y entrada en la célula.}

El paso inicial de la infección de una célula susceptible consiste en la adsorción del virus a la membrana externa de la misma. La unión del NDV a la célula tiene lugar gracias al reconocimiento de receptores específicos en la superficie celular. Estos receptores se caracterizan por exponer restos de ácidos siálicos con los que interacciona la proteína $\mathrm{HN}$ gracias a su actividad hemaglutinante o de unión al receptor. Las glicoproteínas de las membranas celulares y varias glicoproteínas solubles en suero, glándulas salivales o de la orina pueden funcionar como receptores del NDV, siempre que contengan restos de los citados ácidos siálicos. Suzuki et al. (1985) identificaron gangliósidos como receptores en las membranas diana para el NDV y $\mathrm{SeV}$, mientras que Wu et al. (1980) y Oku et al. (1981, 1982a, 1982b) evidenciaron que también las sialoglicoproteínas son receptores naturales para el $\mathrm{SeV}$. Nuestro grupo de investigación ha demostrado que gangliósidos y $\mathrm{N}$-glicoproteínas, pero no las $\mathrm{O}$-glicoproteínas, son importantes en el proceso de la interacción virus-célula (Ferreira et al., 2004b)

El segundo paso en la infección es la fusión de la envoltura vírica con la membrana de la célula diana. Este proceso está mediado por la proteína $\mathrm{F}$ (Choppin y Compans, 1975) y tiene lugar a nivel de la membrana plasmática de la célula hospedadora y a $\mathrm{pH}$ neutro. A diferencia de lo que ocurre en los ortomixovirus, siempre se ha creído que para que se produzca la fusión de membranas no es necesaria la internalización previa de la partícula vírica en un endosoma, ni la activación de la proteína de fusión a $\mathrm{pH}$ ácido. No obstante, la internalización del NDV puede llevarse a cabo por medio de la ruta endocítica, y el pH puede ser un factor que facilite la fusión. (San Román et al., 1999; Cantín et al., 2007).

La proteína $\mathrm{HN}$ desempeña un papel fundamental en el proceso de fusión: en todos los paramixovirus, con algunas excepciones como el virus respiratorio sincitial (RSV) y cepas del virus parainfluenza 5 (PIV5) (Morrison et al., 2003), hay un requerimiento estricto de la $\mathrm{HN}$ homotípica para que $\mathrm{F}$ pueda llevar a cabo la fusión, si bien el mecanismo por el que se produce este control queda por determinar y hay teorías contrapuestas. Una vez producida la unión al receptor de HN, F sufre un cambio conformacional que dispara hacia la membrana diana un pequeño péptido hidrofóbico, el péptido de fusión. Nuevos cambios conformacionales conducen al repliegue de la proteína y al acercamiento de las dos membranas lípidicas hasta que se produce la mezcla de ambas bicapas (en el apartado 1.3 se aborda con más detalle este proceso). 
A continuación, la nucleocápsida del virus penetra en el citoplasma celular y el genoma puede comenzar a transcribirse. Durante todo el proceso el RNA permanece unido a la proteína NP, y sólo los mRNAs que codifican las proteínas del virus permanecen libres, sin asociarse a las proteínas víricas.

\subsubsection{2.- Transcripción primaria.}

La estrategia de replicación de los virus RNA de polaridad negativa (Figura 1.4) fue descubierta precisamente en el NDV (Kingsbury, 1966; Bratt y Robinson, 1967), y ésta consiste en que el mRNA del virus es complementario a su RNA genómico. Como ya hemos dicho, y a diferencia del ciclo de replicación de los ortomixovirus, la transcripción y replicación del RNA de los paramixovirus como el NDV tiene lugar en el citoplasma de la célula hospedadora y no requiere un iniciador exógeno. La proteína vírica $\mathrm{L}$, en asociación con la $\mathrm{P}$, es la responsable de la actividad RNA polimerásica dependiente de RNA (Hamaguchi et al., 1983), y como molde requiere absolutamente el complejo RNA-NP, no pudiendo leer el RNA libre. Los promotores para la transcripción son los únicos sitios de entrada válidos para la polimerasa y siempre están activos: así, con la descapsidación del virus y sin otro estímulo que la presencia citoplasmática de ribonucleósidos trifosfato se originan mRNAs monocistrónicos con cap de 7-metil-guanosina en $5^{\prime}$ y poliadenilados en $3^{\prime}$ al igual que los celulares. La poliadenilación en paramixovirus, al igual que en rabdovirus y ortomixovirus, se produce por una transcripción repetida de una serie de $U$ al final de cada ORF, justo antes de la señal de terminación (GE) (Figura 1.2). Tras ésta, la polimerasa salta la secuencia intergénica no transcrita entre cistrones, reconoce la siguiente señal de iniciación (GS) aguas abajo, y comienza a transcribir un nuevo gen. La sucesiva reiniciación de la transcripción tiene una alta eficiencia, pero no es perfecta: la polimerasa puede soltarse de su molde, con lo que el proceso debe comenzar de nuevo desde el extremo 3' (Lamb y Parks, 2007). Esto da lugar a que paulatinamente se vaya produciendo un gradiente de transcritos, con mayor abundancia de aquellos situados más al extremo 3' del genoma: así el gen NP tiene los niveles más altos de transcripción, y el el gen L los más bajos (Glazier et al., 1977). De esta manera relativamente sencilla, el virus modula la cantidad que necesita de cada una de sus seis proteínas estructurales, y también en este punto es donde se producen las proteínas $\mathrm{V}$ y W, a partir de la edición del mRNA para P (Lamb y Parks, 2007). 


\subsubsection{3.- Replicación del genoma.}

Se ha propuesto un modelo sencillo y directo para explicar el cambio entre transcripción de RNAm y replicación del genoma vírico que tiene lugar durante la infección por paramixovirus; un modelo dependiente de los niveles de expresión de las distintas proteínas del virus (Lamb y Parks, 2007). Así, mientras haya poca cantidad de NP el genoma se sigue transcribiendo, pero cuando en función de la transcripción aquella ha alcanzado ciertos niveles, comienza a asociarse con las cadenas $\operatorname{RNA}(+)$ nacientes, evitando que la polimerasa reconozca las secuencias de regulación o edición y conduciéndola a producir una copia completa (full length) del genoma: éste es el antigenoma $\mathrm{RNA}(+)$, totalmente recubierto por NP, sin cap ni poli-A y que por el mismo mecanismo es replicado para formar nuevas copias del genoma RNA(-) original. De esta manera se originan las nucleocápsidas que se encontrarán en los viriones maduros: las ribonucleoproteínas con RNA, NP y el complejo polimerasa que mientras lleva a cabo su función sobre las anteriores es incorporada a las partículas en gemación. (Kolakofsky et al., 1991).

La transcripción y replicación en paramixovirus y otros mononegavirus se encuentran reguladas por factores celulares: únicamente suplementando con estractos celulares los experimentos de síntesis de RNA in vitro pueden alcanzarse resultados óptimos (Sun et al., 2008). Entre las proteínas que interaccionan con el complejo de la polimerasa en otros paramixovirus se han descrito componentes del citoesqueleto (tubulina en el virus del sarampión (MeV), actina y profilina en RSV), que probablemente proporcionan el soporte físico necesario. El nivel de fosforilación de $\mathrm{P}$ es un elemento regulador clave, y al alterarlo se alterna entre transcripción y replicación en el RSV (Lu et al., 2002). Se ha descrito que la enzima celular implicada en la fosforilación y activación de $\mathrm{P}$ es la serín-treonín kinasa Akt, y que la multifuncional proteína $\mathrm{V}$ regularía este proceso inhibiendo Akt, modulando la acción de la polimerasa por retroalimentación y permitiendo un óptimo de expresión de transcritos viables (Sun et al., 2008, con el PIV5). 


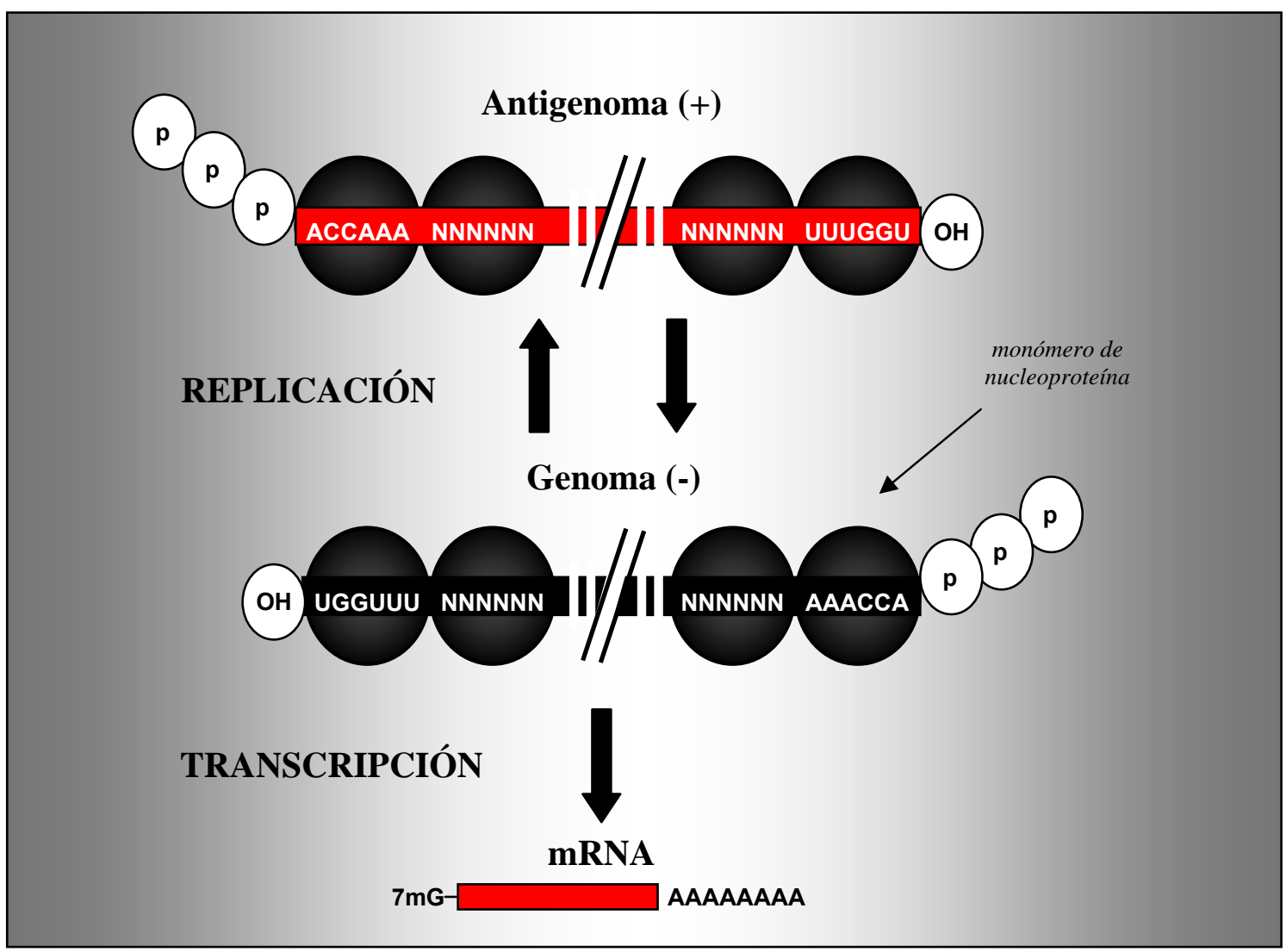

Figura 1.4. Síntesis de RNA en el NDV y otros paramixovirus. El fundamento de la "regla del seis" radica en la necesidad de que la región promotora conservada en 3 ' se encuentre totalmente recubierta por un monómero de la proteína NP. Sólo así puede producirse la replicación.

Durante el proceso de replicación pueden producirse errores por saltos de la polimerasa, que puede pasar directamente de replicar un extremo al opuesto. De esta manera se originan minigenomas defectivos, también conocidos como partículas DI (Defective Interfeering, en inglés, por interferir competitivamente con la replicación de los genomas completos). Estos minirreplicones, que conservan las secuencias leader y trailer necesarias para la replicación pero que han perdido toda la información genética comprendida entre ambas, fueron los que se emplearon para la dilucidación de la "regla del seis" (Calain y Roux, 1993: ver apartado 1.2.3.2), así como en los primeros estudios de genética inversa con virus RNA(-) (Lamb y Parks, 2007), como se comenta más adelante en el apartado 1.4.1. 


\subsubsection{4.- Ensamblaje y liberación de los viriones.}

Mientras se produce la replicación del genoma y se van formando las nucleocápsidas, las glicoproteínas víricas de la envoltura se sintetizan siguiendo la vía retículo endoplasmático-Golgi hasta incorporarse a la membrana plasmática, donde quedan insertas. Durante este proceso de transporte, tanto $\mathrm{F}$ como $\mathrm{HN}$ sufren modificaciones postraduccionales como N-glicosilación, acilación, activación proteolítica de la proteína $\mathrm{F}$ y formación de puentes disulfuro (Morrison et al., 1987; Yoshida et al., 1989).

En cuanto a la proteína $\mathrm{M}$, una vez sintetizada se une a la nucleocápsida, rodeándola. Ese armazón de proteína $\mathrm{M}$ se rodea a su vez de una porción de membrana celular, provocando la salida de la progenie vírica de la célula (Schmitt y Lamb, 2004). La fracción de membrana adquirida por los viriones lleva las glicoproteínas $\mathrm{HN}$ y $\mathrm{F}$ que formarán las espículas del virus. En el NDV, el lugar de interacción entre M y HN para desencadenar todo este proceso está en la membrana plasmática (García-Sastre et al., 1989), aunque en otros paramixovirus como $\mathrm{SeV}$ (Stricker et al., 1994) esta interacción ya se lleva a cabo en el retículo endoplasmático o en el aparato de Golgi. La proteína de la matriz del NDV es capaz por sí sola de producir la gemación, siendo el motor suficiente y necesario de la misma (Shnyrova et al., 2007; Pantua et al., 2006; Figura $1.5)$.

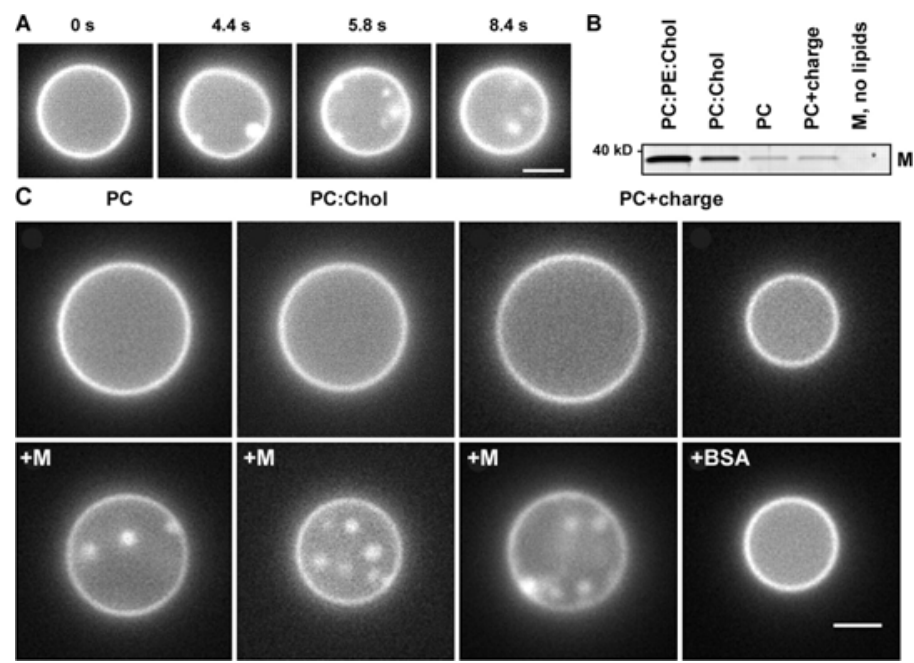

Figura 1.5.- Formación de vesículas intraluminales en liposomas por la adición de proteína M del NDV purificada. (A).- Secuencia temporal de la formación de vesículas tras la adición de la proteína (B).- Adsorción de la proteína a diferentes liposomas de distinta composición lipídica (C).- Formación de vesículas en liposomas de distinta composición lipídica. La barra marca $2 \mu \mathrm{m}$. (Shnyrova et al., 2007). 


\section{3.- LA PROTEÍNA DE FUSIÓN DEL NDV (F)}

La proteína de fusión (F) del NDV es la encargada de permitir la penetración del virus mediante la inducción de la fusión entre las membranas vírica y celular. A consecuencia de esta fusión, la nucleocápsida puede liberarse en el citoplasma y comenzar el ciclo replicativo del virus. Posteriormente, la proteína de fusión expresada en la membrana plasmática puede producir la fusión entre distintas células adyacentes formando sincitios, células gigantes multinucleadas, un efecto citopático que conduce a la necrosis tisular in vivo y puede ser un mecanismo de propagación del virus.

La proteína $\mathrm{F}$ es un homotrímero. Cada una de sus tres subunidades componentes, de 554 aminoácidos cada una (Figura 1.6), es sintetizada como un precursor inactivo denominado $\mathrm{F}_{0}$. Para que la proteína pueda ser biológicamente activa este precursor debe ser proteolizado por proteasas de la célula hospedadora en un sitio específico de corte. La proteolisis divide $\mathrm{F}_{0}$ en dos cadenas unidas por puentes disulfuro, $\mathrm{F}_{1}$ y $\mathrm{F}_{2}$, de unos 55 y $12 \mathrm{kDa}$ respectivamente, y genera un nuevo extremo N-terminal en $F_{1}$. Juntas, $F_{1}$ y $F_{2}$ forman una proteína transmembrana de tipo $I$, que atraviesa una única vez la membrana, con un dominio extracelular de 500 aminoácidos, un dominio transmembrana relativamente largo, de 25-30 residuos, y un pequeño dominio intracelular en su extremo C-terminal. Con el procesamiento proteolítico aparece en el extremo N-terminal de $F_{1}$ un pequeño péptido hidrofóbico clave para la funcionalidad de la proteína: el péptido de fusión (Figura 1.6A). Junto a él y junto al dominio transmembrana se encuentran dos regiones conocidas como heptadas repetidas (HRA y HRB, respectivamente), consistentes en un patrón repetido (4-3) de residuos hidrofóbicos. Una tercera heptada repetida (HRC) se localiza junto al extremo Cterminal de $\mathrm{F}_{2}$ (Figura 1.6A). Como todas las proteínas $\mathrm{F}$ de paramixovirus, la del NDV se encuentra glicosilada: presenta 5 sitios de $N$-glicosilación en su ectodominio. La mutación de estos residuos conduce a alteraciones en el plegamiento y la actividad fusogénica de la proteína (McGuiness et al., 2001), aunque su posición no se encuentra conservada entre los distintos miembros de la familia (Lamb y Parks, 2007). 

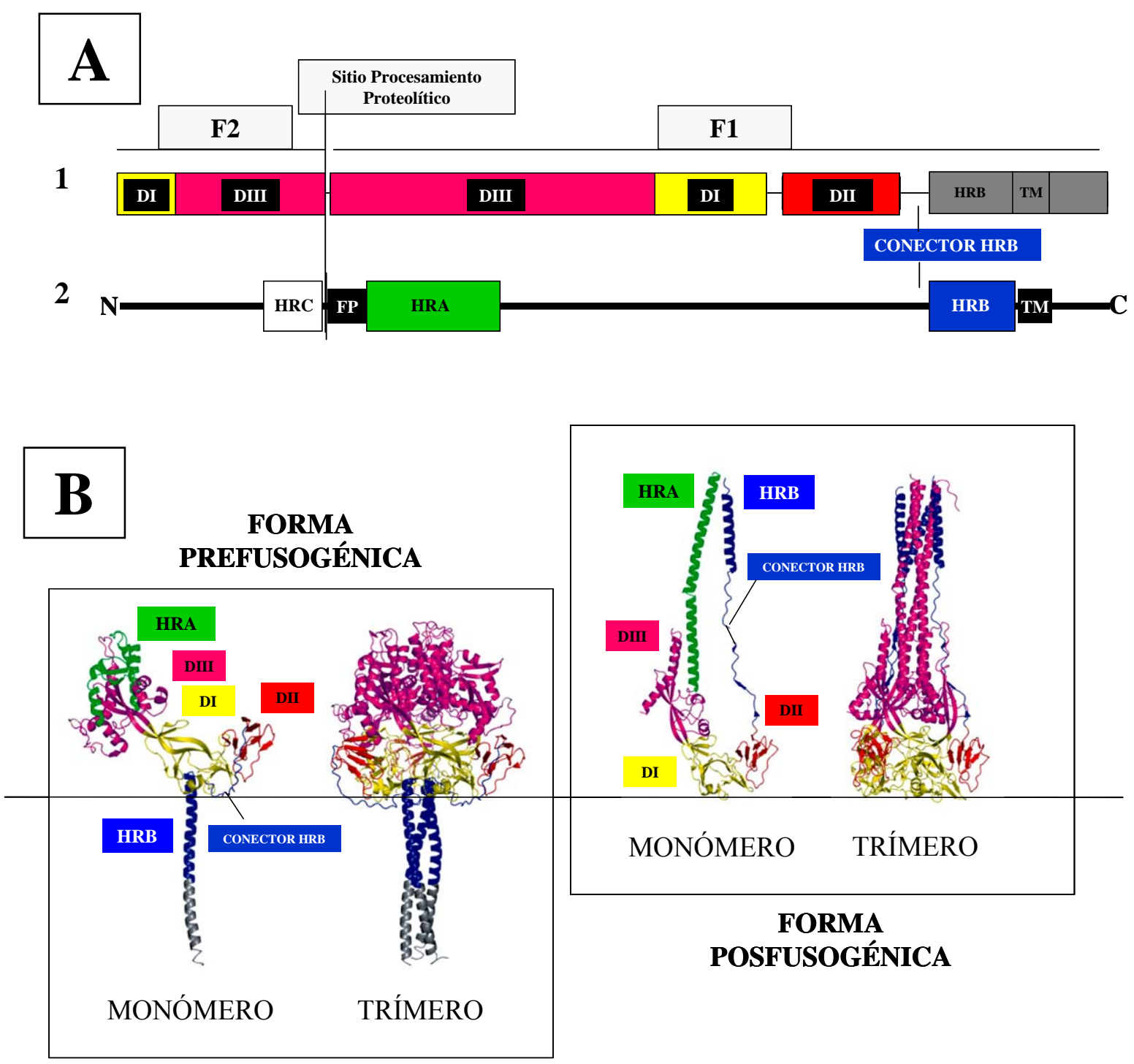
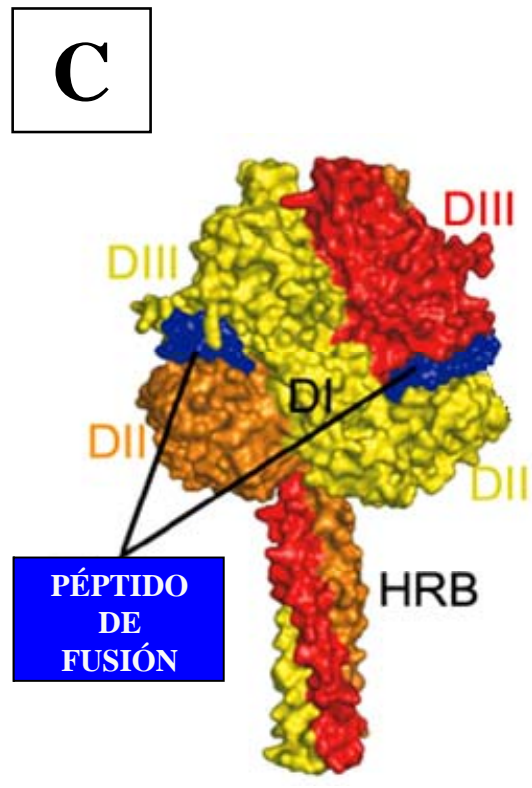

Figura 1.6.- Estructura de la proteína $F$ de los paramixovirus. (A).- Estructura primaria de una subunidad de la proteína con los dominios en los que se divide (1) y la correspondiente localización de las regiones $\mathrm{HR}$, el péptido de fusión y la secuencia de corte proteolítico que divide F1 y F2. (B).- Estructura atómica de los monómeros y trímeros de la proteína $\mathrm{F}$, en sus formas prefusogénica $\mathrm{y}$ posfusogénica. Se ha conservado el patrón de colores de (A). HRA sólo se ha destacado (en verde) en el monómero. (C).- Localización del péptido de fusión entre los dominios DIII y DII de distintas subunidades en la forma trimérica prefusogénica de la proteína. Las distintas subunidades aparecen en amarillo, naranja y rojo; los péptidos de fusión visibles, en azul (adaptado de Yin et al., 2006). 
Se cree que la proteína $\mathrm{F}$ promueve la fusión acoplando una serie de cambios conformacionales irreversibles en su estructura a la yuxtaposición de las membranas, pasando de un estado inestable a otro de mínima energía, estable. En el virión se supone que la proteína se encuentra en el estado inestable, prefusogénico, ya dispuesta para activar la fusión una vez ha sido procesada proteolíticamente. La serie de procesos que conducen a este efecto y el mecanismo propuesto para el mismo son analizados a continuación.

\subsection{1.- LAS PROTEÍNAS DE FUSIÓN VÍRICAS CLASE I. LA HORQUILLA HELICOIDAL.}

Las proteínas de fusión de los paramixovirus pertenecen a la clase I de proteínas de fusión víricas, que tiene por modelo tipo a la hemaglutinina del virus de la gripe. También incluye las proteínas de fusión de los retrovirus como Env/gp160 del HIV, de los coronavirus o de otros miembros del orden Mononegavirales como el filovirus Ebola. La clase I de proteínas de fusión se caracteriza por el replegamiento irreversible de la proteína hasta una estructura altamente estable con un núcleo de seis $\alpha$-hélices superenrrolladas (estructura denominada coiled coil en inglés). En contraposición, las de proteínas de fusión de clase II, propia de flavivirus y alfavirus, tienen una arquitectura distinta, compuesta principalmente por láminas $\beta, \mathrm{y}$ un mecanismo funcional distinto (Kielian y Rey, 2006; Lamb y Jardetzky, 2007).

Datos biofísicos primero y cristalográficos después mostraron que la estructura posfusogénica de las proteínas que se engloban en la clase I compartían un núcleo trimérico formado por tres hélices derivadas de HRA y otras tres derivadas de HRB dispuestas de forma antiparalela con respecto a las primeras (Skehel y Wiley, 1998; Paterson et al 1999., Lamb y Parks, 2007). Este haz de seis hélices superenrolladas (6HB, six-helix bundle) es en realidad una horquilla: por su naturaleza antiparalela presenta en el mismo extremo tanto el péptido de fusión (que en la estructura primaria de la proteína está en el extremo N-terminal de HRA) como el dominio transmembrana (C-terminal de HRB). Su estructura y enorme estabilidad (la temperatura precisa para disociar el complejo es de cerca de $100^{\circ} \mathrm{C}$ ) es consecuencia de las características de las heptadas repetidas. Como se indica en la Figura 1.7B, en las HR existe un patrón de aminoácidos hidrófobicos se repite cada siete residuos, designándose cada uno de "a" a 
la "g" (Lupas, 1996). Las HR con residuos hidrofóbicos o neutros en las posiciones "a" $\mathrm{y}$ “ $\mathrm{d}$ " pueden formar $\alpha$-hélices en las cuales los restos hidrofóbicos se sitúan a un mismo lado de la hélice, y varias de éstas pueden asociarse para generarar estructuras de orden superior, como las hélices superenrrolladas que conforman el 6HB.

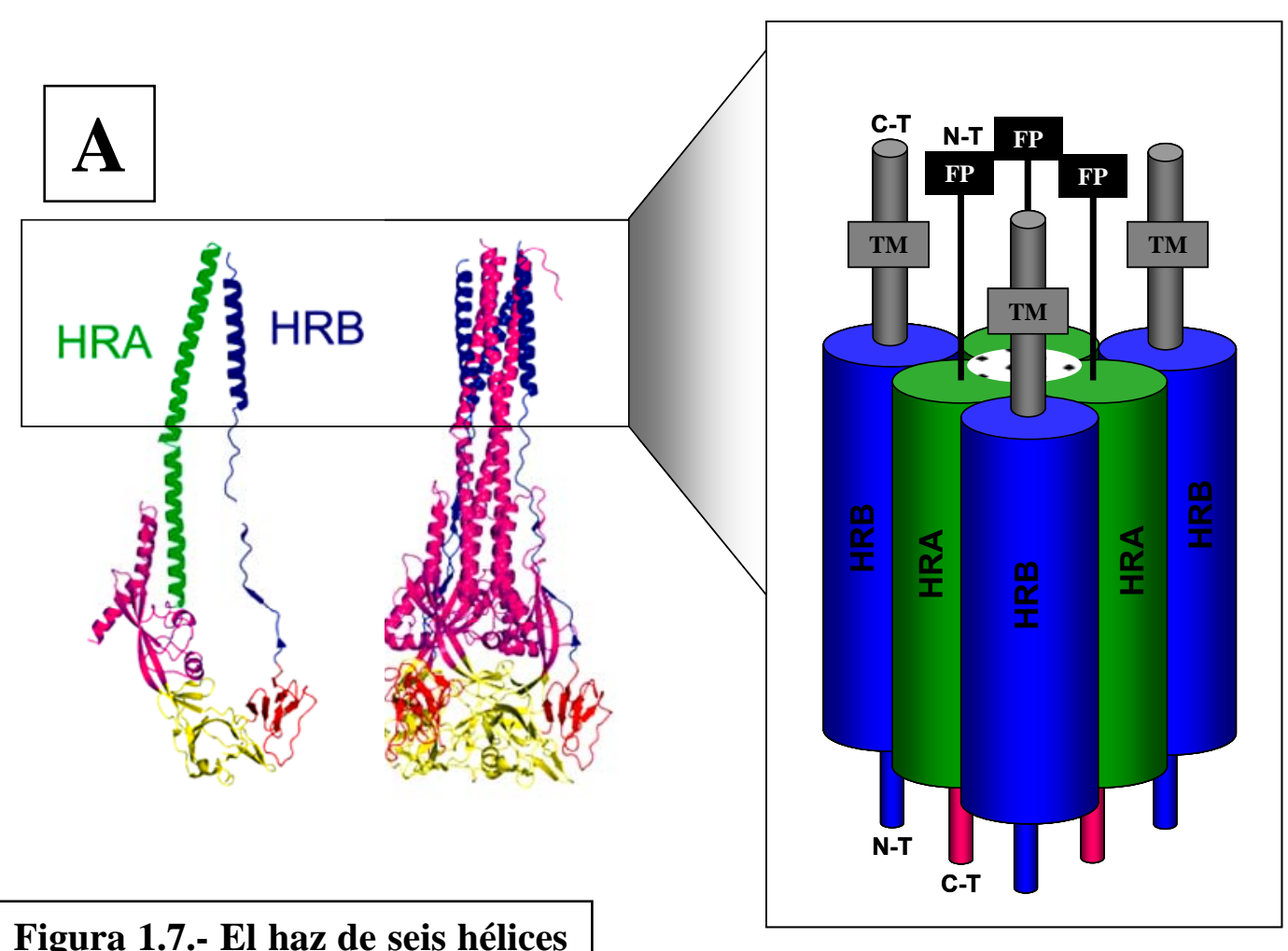
(6HB).

(A).- Representación esquemática del 6HB presente en la forma posfusogénica de la proteína $\mathrm{F}$. Las tres hélices formadas por HRA forman el núcleo central: a sus surcos laterales se asocian las tres hélices de HRB de forma antiparalela. (B).- Vista superior esquemática del 6HB. Los residuos a y d (hidrofóbicos) de las heptadas repetidas HRA interaccionan en el centro de la espiral superenrrollada formando un núcleo hidrofóbico. (TM: dominio transmembrana; N$\mathrm{T}$ : extremo amino-terminal; C-T: extremo carboxilo-terminal; FP: péptido de fusión. (Yin et al., 2006; Morrison, 2003) 
El núcleo $6 \mathrm{HB}$ representa el estadio final, de mínima energía, alcanzado tras la fusión de membranas. Es posible bloquear el tránsito a la conformación que presenta el 6HB mediante la utilización de péptidos sintéticos derivados tanto de la HRA como de la HRB implicadas en su formación (Russell et al., 2001), indicando que la proteína atraviesa por una serie de estadios discretos en el plegamiento hacia su forma más estable en los que se exponen secuencialmente primero HRB y luego HRA hasta la inmersión del péptido de fusión en la membrana diana, tras lo cual la proteína se encuentra anclada a la membrana vírica por su dominio transmembrana y a la membrana celular de la célula hospedadora por el péptido de fusión. Cuando tras nuevos plegamientos se forma el 6HB ambas membranas se yuxtaponen: se cree que la energía liberada por el replegamiento, al acoplarse a la unión de las membranas, es la que permite la fusión de las mismas.

\subsection{2.- ESTRUCTURAS ATÓMICAS DE LA PROTEÍNA F.}

En los últimos años se han determinado por cristalografía de rayos $\mathrm{X}$ las estructuras atómicas de la forma prefusogénica de la proteína F del PIV5 (Yin et al., 2006) y de las posfusogénicas del hPIV3 y el NDV (Yin et al., 2005; Chen et al., 2001). Esto significa que las proteínas $\mathrm{F}$ de los paramixovirus, junto con la proteína de fusión HA del virus de la gripe, son las únicas proteínas víricas de fusión clase I de las que se dispone de esta información, y gracias a ello y al estudio de los 6HB (mediante péptidos sintéticos derivados de HRA y HRB) se ha podido desarrollar un modelo para la fusión de membranas que promueven, como se detallará a continuación (revisado por Lamb y Parks, 2007; Lamb y Jardetzky, 2007; Russell y Luque, 2006; Lamb et al., 2005).

\section{Estructura de la forma prefusogénica}

La primera cristalización de una proteína $\mathrm{F}$ de paramixovirus fue publicada por Chen et al. en 2001. En ella los autores afirmaban presentar la forma prefusogénica de la F del NDV; sin embargo, la muestra se encontaba parcialmente proteolizada, faltando regiones claves de la proteína, y un estudio posterior con la F de hPIV3 (Yin et al., 2005) reveló que en realidad la forma descrita por Chen y colaboradores correspondía en realidad a la horquilla posfusogénica del 6HB. Se comprobó que la expresión del dominio extracelular de la proteína, soluble, conducía a un repliegue espontáneo del 
mismo hacia la forma más estable, lo que llevó a la hipótesis de que tanto el anclaje transmembrana de la proteína como su dominio intracelular deben jugar un importante papel en el mantenimiento de la forma inestable y potencialmente funcional, susceptible de ser activada, como otros datos parecen confirmar (Waning et al., 2004). Por otra parte, este plegamiento espontáneo hacía difícil la obtención de la forma inestable para su análisis cristalográfico. El problema se solventó con la adición de un dominio transmembrana soluble procedente de levaduras que sustituyera al hidrofóbico. Así, empleando como modelo el virus PIV5, pudo analizarse finalmente una forma completa, en el estado inestable y prefusogénico, de una proteína F (Yin et al., 2006).

La estructura (Figura 1.6B, izquierda) reveló una proteína trimérica con una gran cabeza globular unida a un tallo constituido por las $3 \mathrm{HRB}$ superenrrolladas que orienta la cabeza hacia el exterior de la membrana vírica. La cabeza está formada por tres dominios (DI-DIII) por cada subunidad, entre las cuales hay gran número de interacciones. La base de la cabeza, junto al tallo, lo forman los dominios DI y DII y la parte superior la constituye el dominio DIII, cerrando una cavidad interior que ocupa el centro de la cabeza. El extremo C-terminal de DII se extiende por el exterior de la estructura hasta la base de la cabeza, formando un conector que liga HRB. En DIII se encuentran tanto HRC (como una única $\alpha$-hélice) como HRA, dividida en 11 segmentos estructurales distintos (cuatro hélices, dos hebras $\beta$ y cinco giros, ver Figura 1.8). La estructura de la cabeza forma tres vértices laterales que se proyectan desde el eje: en cada uno de los extremos de esos vértices se encuentra el punto de procesamiento proteólitico que permite la liberación del péptido de fusión. Éste se encuentra embebido entre dos subunidades del trímero (Figura 1.6C), formando parte de DIII: su parte Nterminal está expuesta en la superficie de la cabeza luego se repliega de forma que el extremo C-terminal se halla enterrado en la proteína, creando un pequeño núcleo hidrofóbico entre DIII de su subunidad y DII de otra.

\section{Comparación de las formas pre y posfusogénicas}

Como ya hemos mencionado, la estructura de la forma posfusogénica de la proteína F de hPIV3 fue descrita en 2005 por Yin et al. (Figura 16B, derecha) apoyándose en los datos obtenidos previamente por Chen et al. con el NDV. A los autores les sorprendió el encontrarse ante una forma posfusogénica con el núcleo $6 \mathrm{HB}$ 

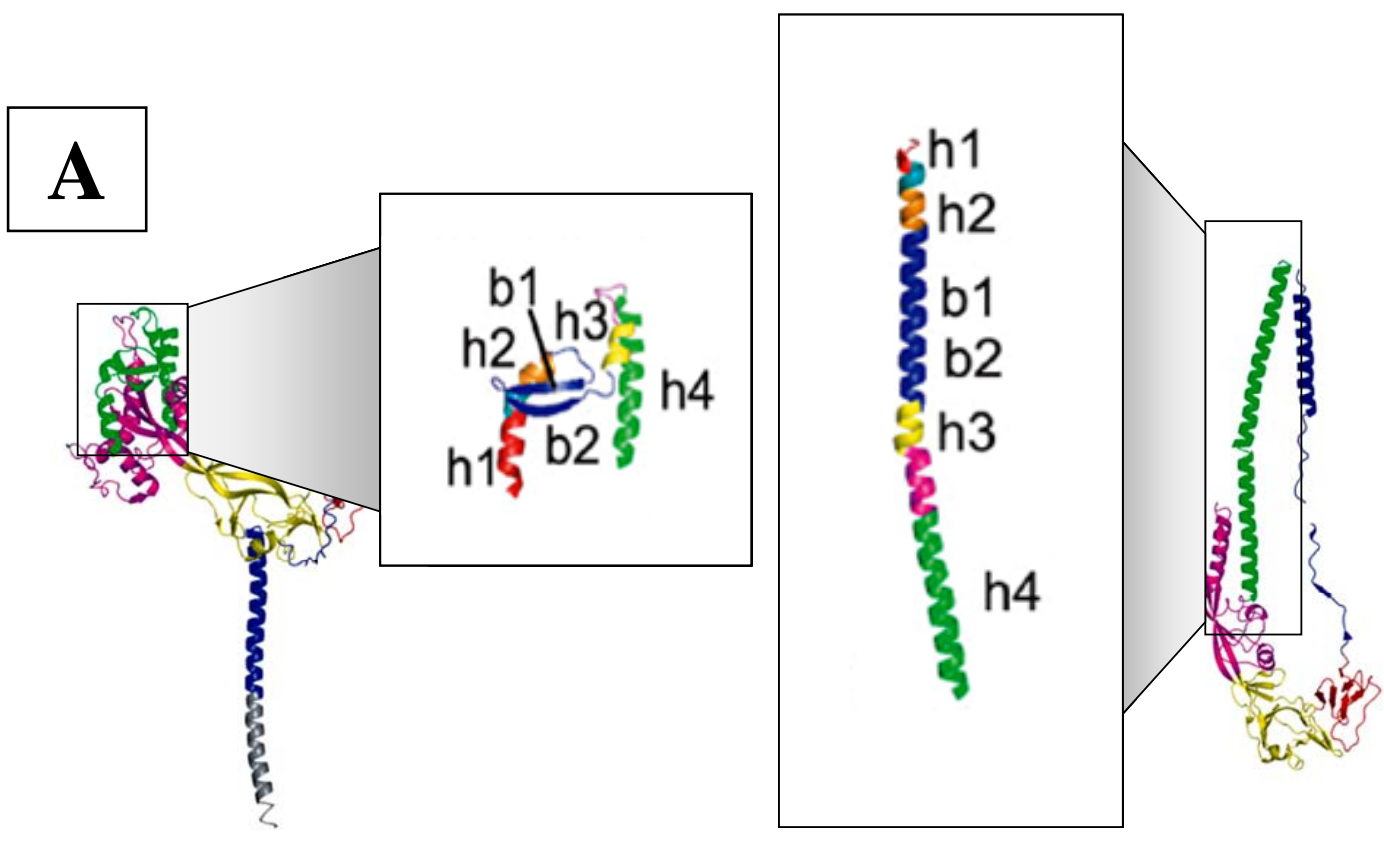

\section{FORMA PREFUSOGÉNICA}

\section{FORMA POSFUSOGÉNICA}
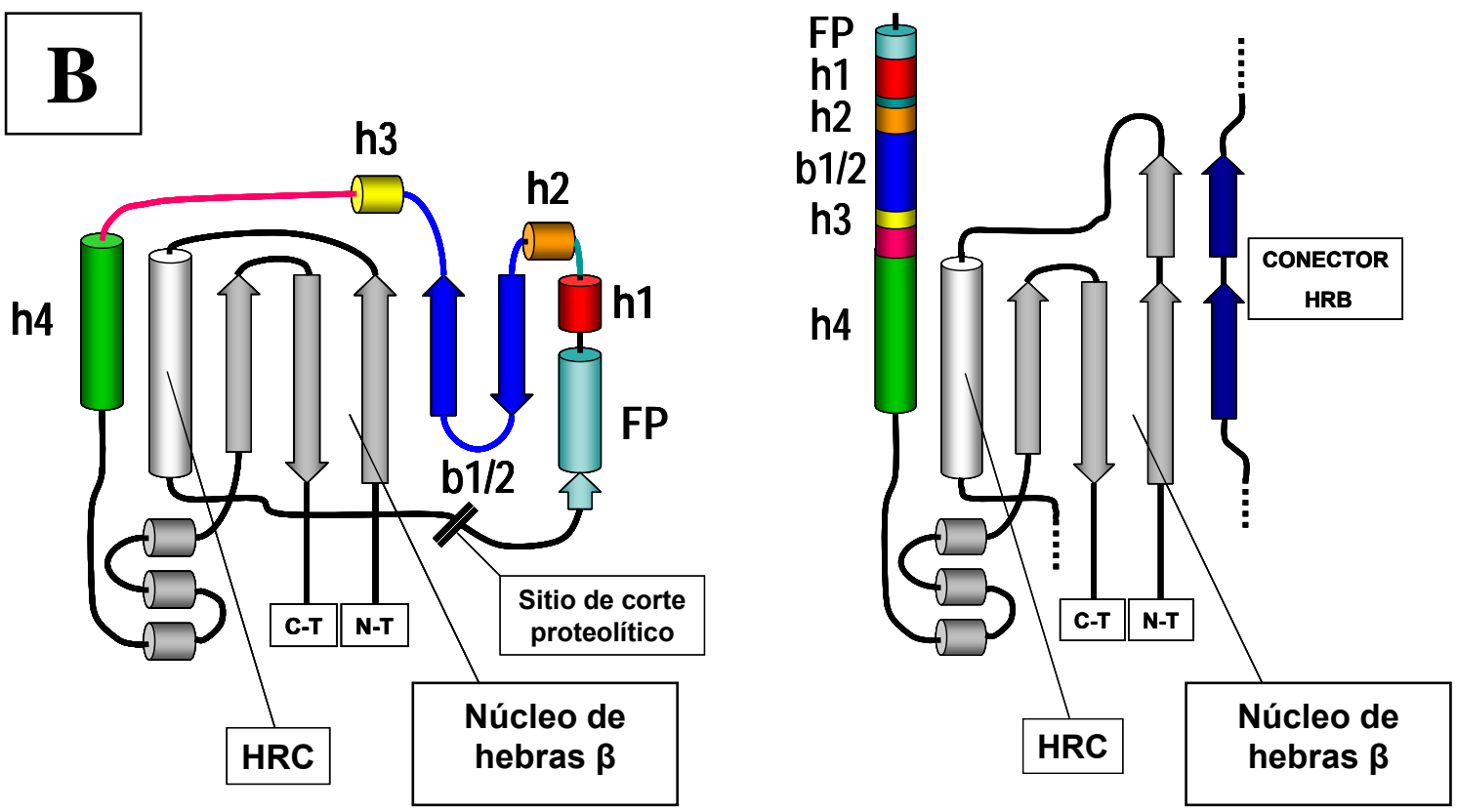

Figura 1.8.- Plegamiento y replegamiento de DIII y HRA. (A).- En la forma prefusogénica de la proteína HRA se encuentra dividida en 11 segmentos (h1, h2, b1, b2, b3, b4 y sus respectivos conectores; estos segmentos se reestructuran en una única hélice $\alpha$ en la forma posfusogénica que dispara el péptido de fusión hacia la membrana diana. (B).- Diagramas de la estructura secundaria del dominio DIII en las formas pre y posfusogénicas. Las hélices se representan como cilindros y las hebras como flechas. El patrón de colores es el mismo que en A. El núcleo de hebras $\beta$ en la forma prefusogénica se ve ampliado por las hebras b1 y b2 de HRA; en la forma posfusogénica son hebras formadas por el reorganizado conector HRB las que toman ese papel. Adaptado de Yin et al., 2006. 
bien definido, pues la forma soluble con la que trabajaron no había sido activada proteolíticamente y se creía que no podía haber transición de un estado a otro en la proteína sin la activación del péptido de fusión. No obstante, numerosas pruebas además de la presencia del $6 \mathrm{HB}$ apoyaban que se trataba de la forma posfusogénica de la proteína y no de la fusogénicamente activa: la estructura no explicaba el mecanismo de inhibición por péptidos derivados de HRA y HRB que hemos comentado anteriormente, no permitía elucidar un mecanismo de fusión por el que se yuxtapusieran las membranas y no explicaba los efectos causados por mutaciones desestabilizantes que incrementaban sustancialmente la fusión (Paterson et al.,2000; Russell et al., 2001).

Las formas pre y posfusogénicas descritas adoptan conformaciones radicalmente distintas, lo que está en consonancia con un proceso de transición de la una a la otra. La forma posfusogénica (Figura 1.6B, derecha) presenta una cabeza, cuello y tallo, con una forma general que ha sido descrita como un tee de golf, en contaposición a la forma "de champiñón" de la forma prefusogénica. Entre ambas formas no se conserva ninguna de las interacciones entre subunidades. Los dominios DI y DII son similares en ambas estructuras, si bien se reubican en la forma posfusogénica, compactando la cabeza. El dominio DIII sufre un gran cambio estructural que se muestra en la Figura 1.8: HRA se repliega a partir del resorte de 11 segmentos en el que se encontraba dividida y forma una única hélice $\alpha$ que dispara el péptido de fusión $\sim 120 \AA ̊$ hacia el exterior de la envoltura vírica. La posición relativa del tallo y el dominio transmembrana con respecto a la cabeza se invierte: las HRB aparecen ahora dispuestas de forma antiparalela junto a las HRA formando el $6 \mathrm{HB}$ que ahora constituye el tallo de la nueva conformación. Ello supone que en la transición entre las formas pre y posfusogénicas las hélices HRB deben separarse, girar alrededor de la cabeza y reposicionarse en el extremo opuesto de la proteína hasta formar la horquilla de fusión.

Si bien los datos comentados han sido descritos fundamentalmente para dos paramixovirus concretos, PIV5 y hPIV3, por su comparación con la estructura descrita por Chen et al. (2001) y por la conservación de residuos clave en la secuencia primaria, pueden extrapolarse sin aparentes complicaciones tanto al NDV como al resto de los miembros de la familia Paramyxoviridae. 


\subsection{3.- MECANISMO DE LA FUSIÓN DE MEMBRANAS MEDIADA POR LA PROTEÍNA F.}

A raiz de la información estructural que acabamos de comentar se ha propuesto un modelo para el mecanismo de fusión de membranas inducida por la proteína $\mathrm{F}$ en los paramixovirus (Figura 1.9). En un primer paso, el tallo de la forma prefusogénica se abre: las tres hélices de las HRB se separan y se rompen las interacciones en la base de la cabeza. Este estadio de tallo abierto (Figura 1.9.2) es consecuente con los efectos desestabilizantes de mutaciones entre el tallo y la cabeza analizadas en el PIV5 (Paterson et al., 2000), que resultarían hiperfusogénicas por desestabilizar esa zona y facilitar la apertura del tallo. Tambien concuerda con los datos obtenidos por péptidos inhibidores: los péptidos derivados de HRA (que interaccionan con HRB y bloquean su actuación) inhiben un intermediario temprano, previo a la exposición de HRA (Russell et al., 2001; Russell et al., 2003). La apertura del tallo puede originar nuevos cambios en $\mathrm{F}$ afectando al empaquetamiento de DII y el péptido de fusión (cambios que serían transmitidos gracias al conector HRB), y alterando la estabilidad de las interacciones entre las subunidades de la cabeza. La consecuencia final de estos cambios es la reorganización radical de DIII, el ensamblaje de HRA y la translocación del péptido de fusión hacia la membrana diana, donde queda enterrado gracias a su carácter hidrofóbico. Este estadio se denomina prehorquilla (Figura 1.9.3), y puede detectarse por la acción de péptidos inhibidores derivados de HRB, que se unen a las recién expuestas hélices HRA (Russell et al., 2001). La retirada del péptido de fusión de su posición entre las subunidades puede generar un giro hacia el interior de DII, la generación de nuevas interacciones y la compactación de la cabeza. Por la reorganización de HRA queda expuesto un núcleo de hebras $\beta$ en DIII que previamente se encontraba rodeado por los distintos segmentos del resorte: el conector HRB se asocia a ese núcleo como una hebra $\beta$ paralela y permite la reubicación de las hélices HRB (Figuras 1.8B y 1.9.4). Finalmente, las hélices HRB se asocian a los surcos expuestos por las hélices HRA y se forma el estadio del 6HB (Figura 1.9.5), terminando el repliegue de la proteína hasta su forma más estable y poniendo en contacto la membrana unida al péptido de fusión (diana) y la unida al dominio transmembrana (vírica). 


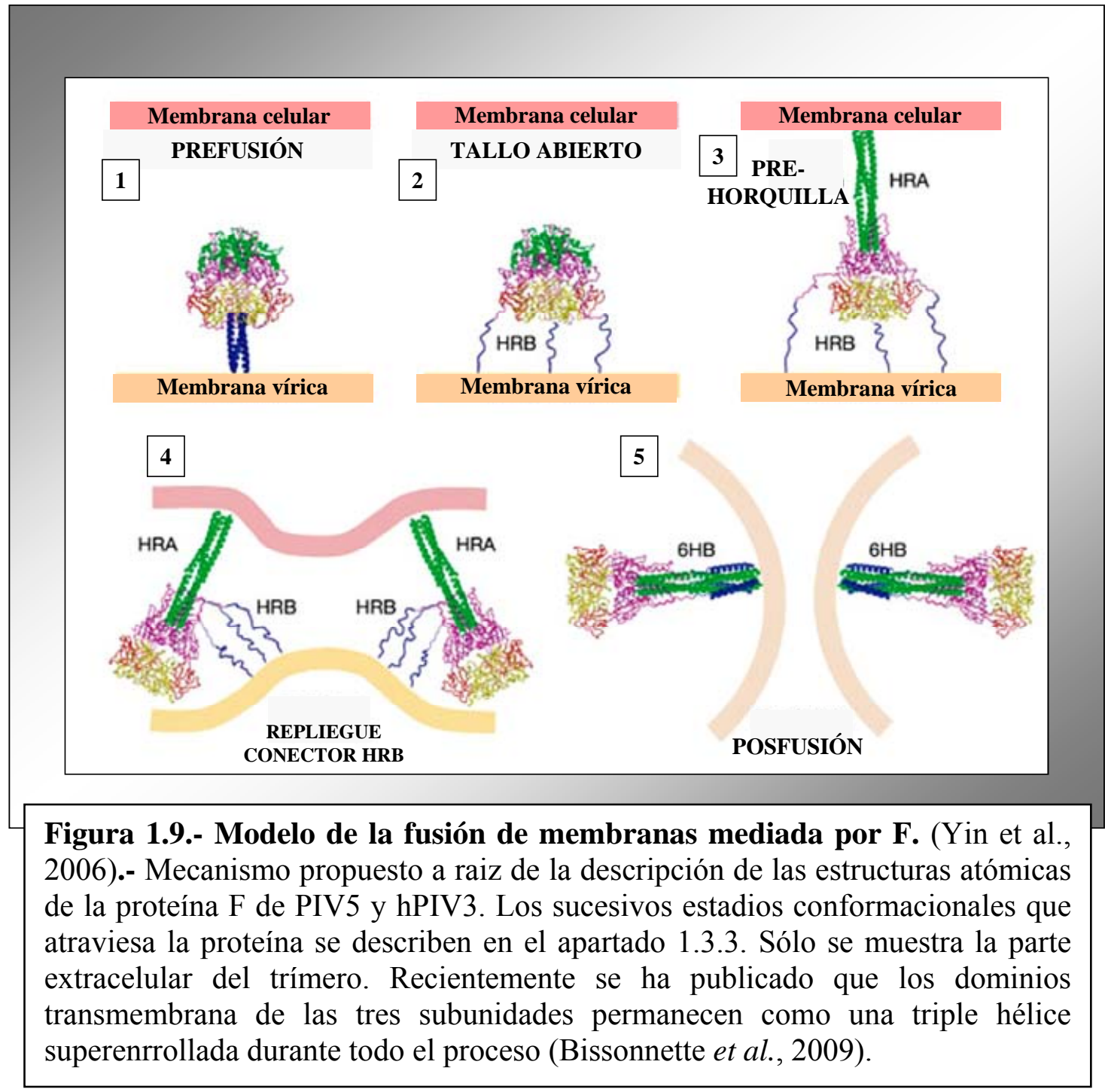

\subsection{4.- REGULACIÓN DE LA FUSIÓN. ACTIVIDAD PROMOTORA DE HN.}

El procedimiento regulador del mecanismo de fusión citado en el apartado anterior se desconoce. Es bien conocido que en el caso de la proteína HA del virus de la gripe es el descenso del $\mathrm{pH}$ en el interior del endosoma el factor desencadenante de los cambios conformacionales de la proteína y por ende de la fusión. Sin embargo los paramixovirus desencadenan la fusión a $\mathrm{pH}$ fisiológico y en la misma membrana plasmática, por lo que deben existir factores que determinen que dicha fusión se lleve a cabo en el lugar y el momento adecuados. Todas las proteínas F de los paramixovirus comparten la dependencia de la proteína de unión a receptor para desencadenar fusión (Lamb et al., 2006; Morrison, 2003), si bien en algunos de ellos tal dependencia es relativa (las proteínas F de PIV5, RSV o el virus del sarampión pueden ser fusogénicas 
por sí sólas). Es más: debe ser la proteína HN homotípica, perteneciente al mismo virus, la que se coexprese con F para producir la fusión (Lamb y Parks, 2007). Este hecho parece indicar que $\mathrm{HN}$ (o H, o G, en función del género del virus) es la clave reguladora del proceso. Se ha hipotetizado con que existe una interacción específica entre F y HN, lo que parece demostrado con ensayos de coinmunoprecipitación (Melanson y Iorio, 2006), y se han realizado numerosos intentos por localizar la región exacta de esa interacción, con análisis de mutantes en diversas regiones de HN. Sin embargo muchos de esos trabajos resultan difíciles de interpretar por afectar las mutaciones no sólo a la actividad promotora de fusión, sino también a las actividades hemaglutinante y/o neuraminidásica de la proteína. Aún así, los grupos de Ronald Iorio y Trudy Morrison han encontrado diversas mutaciones en la HN del NDV que afectan a su actividad promotora de fusión sin alterar su capacidad de unión al receptor. Estas mutaciones se han descrito en la cabeza (Deng et al. 1994; Mirza et al., 1994); en las heptadas repetidas del tallo (Deng et al., 1995; Melanson y Iorio, 2006; Sergel et al., 1993; Stone-Hulslander y Morrison, 1999) y en el dominio transmembrana (McGinnes et al., 1993). La construcción de moléculas quiméricas con fragmentos de HN de NDV y de hPIV3 ha mostrado que la actividad promotora de fusión se centra en el tallo y, al menos en parte, también en la cabeza (Deng et al., 1994). También hay datos que afirman que un fragmento del tallo de HN puede unirse a HRB en el tallo de F (Gravel y Morrison, 2003), aunque otros datos lo rebaten (Melanson y Iorio, 2006).

Un modelo que racionalizase toda esta cantidad de información podría ser el siguiente (Lamb y Parks, 2007): la unión al ligando de HN desencadenaría un cambio conformacional en ésta que a su vez produciría la apertura del tallo en F y el disparo del péptido de fusión. Con este modelo $\mathrm{F}$ y $\mathrm{HN}$ actuarían conjuntamente como un ensamblaje proteico para dirigir la fusión en el momento y lugar precisos. En el NDV, la unión de $\mathrm{HN}$ al ligando se ha propuesto como desencadenante de una reordenación en sus dos dímeros que expone un segundo sitio de unión a ácidos siálicos, sin actividad sialidásica, descubierto tras el análisis cristalográfico de la proteína (Crennell et al., 2000, Zaitsev et al., 2004). La nueva conformación amplia la superficie entre los dímeros y los autores mencionados sugieren que ello libera $\mathrm{F}$ de su unión a $\mathrm{HN}$ y le permiten desencadenar la fusión. El segundo sitio receptor de HN mantendría las membranas con la suficiente proximidad al no residir en él la actividad neuraminidásica presente en el primero, que podría liberar la proteína del receptor y alejar espacialmente 
una membrana de otra. Este modelo falla, no obstante, al no explicar el papel del tallo en el proceso, que se ha demostrado fundamental. Tampoco puede ser un modelo generalizado para todos los paramixovirus, puesto que aparte del NDV sólo se ha propuesto un segundo sitio receptor en hPIV3 (Porotto et al., 2007) y, como última evidencia en contra, si se evita el cambio conformacional de HN mediante la adición de nuevos puentes disulfuro no se aprecia un descenso en la promoción fusogénica (Mahon et al., 2008). Un mecanismo alternativo propuesto para el PIV5 implica cambios en la oligomerización de $\mathrm{HN}$ sin grandes transformaciones conformacionales. Estos cambio se transmitirían a la proteína F, activando la fusión (Yuan et al., 2005).

Se ha descrito una mutación en la proteína $\mathrm{F}$ del NDV que escapa de la necesidad de HN (Sergel et al., 2000). Esta mutación se localiza entre HRA y HRB, región que en la forma prefusogénica de la proteína se encuentra en el núcleo del dominio DIII y establece interacciones con la segmentada HRA. Estudios posteriores mostraron que, si bien la proteína mutante mantiene siempre un fenotipo más fusogénico que el del tipo silvestre, su independencia de $\mathrm{HN}$ sólo se logra en determinados tipos celulares ( $\mathrm{Li}$ et al., 2005). La mutación, una sustitución de una leucina por una alanina, puede desestabilizar DIII y reducir la energía de activación precisa para que se dispare el proceso de fusión. Según el contexto (i.e., el tipo celular), esa reducción puede alcanzar un nivel tal que no sea precisa la cooperación de HN. El papel de $\mathrm{HN}$ en el proceso natural de fusión sería por tanto el de, llegado el momento, rebajar la energía de activación de F. La barrera energética y la manera de saltarla diferiría entre los distintos paramixovirus, de ahí la necesidad de una proteína ayudante especializada, homotípica, para cada caso.

Recientemente se ha propuesto un nuevo mecanismo de regulación que actuaría conjuntamente con $\mathrm{HN}$, pero independiente de ella, en la promoción de fusión. Se ha descrito que la formación de tioles libres en la proteína $\mathrm{F}$ es necesaria para la fusión en el NDV (Jain et al.,2007), y que la aparición de esos radicales en las cisteínas de la proteína tiene lugar después de la unión del virus al receptor pero antes de que la proteína sufra la cascada de cambios conformacionales (Jain et al., 2009). En estos trabajos se propone que la actividad de enzimas disulfuro-isomerasas $u$ otras tiolisomerasas presentes en la membrana plasmática es la responsable de estos cambios químicos. La proteína $\mathrm{HN}$ facilitaría la interacción de la proteína $\mathrm{F}$ con las enzimas 
celulares. La formación de tioles reestructuraría los puentes disulfuro de la $\mathrm{F} y$ contribuiría al replegamiento de la misma, como se ha mostrado en otras proteínas de fusión en otros virus como el HIV (Markovic et al., 2004) o Sindbis (Abell y Brown, 1993).

\subsection{5.- LA PROTEÍNA F Y LA VIRULENCIA DEL NDV.}

Como se ha mencionado anteriormente, la proteína $\mathrm{F}$ es sintetizada como un precursor inactivo $\mathrm{F}_{0}$. Es preciso que $\mathrm{F}_{0}$ sea dividido proteolíticamente en dos cadenas unidas por puentes disulfuro $\left(\mathrm{F}_{1} \mathrm{y}_{2}\right)$ para que la molécula pueda ser fusogénicamente activa (aunque, como hemos comentado con anterioridad, la activación del precursor no es precisa para que la proteína sufra los cambios conformacionales hasta el estado postfusogénico). En el NDV el corte de $\mathrm{F}_{0}$ es el principal determinante de la virulencia de las cepas, su infectividad y patogenicidad. Son precisas dos enzimas en la célula hospedadora para que la proteolisis tenga lugar: una proteasa que corte el extremo carboxilo en un residuo de arginina y una carboxipeptidasa que retire los resíduos básicos. Tanto los NDV de distintas cepas como todos los miembros de la familia Paramyxoviridae pueden dividirse en dos grupos: aquellos que tienen proteínas $\mathrm{F}$ con múltiples resíduos básicos en el sitio de corte y aquellos que tienen un único aminoácido básico. Los que tienen un sitio multibásico pueden ser activados en la red trans del aparato de Golgi por la furina, una endoproteasa similar a la subtilisina, o por proteasas similares. Por el contrario, aquellos genotipos que no tienen un sitio de corte multibásico no procesan intracelularmente $\mathrm{F}_{0}$, que se expresa en la membrana celular y en la de los viriones en su forma inactiva. En estos casos, es precisa la presencia de una proteasa extracelular para la activación proteolítica. En el líquido alantoideo del huevo de gallina se ha identificado una de esas proteasas, homóloga de la protrombina denominada factor Xa. También se han encontrado proteasas similares en el epitelio bronquial, secretadas por las células Clara. En condiciones experimentales, la adición de tripsina puede igualmente activar la F en este tipo de virus. En el NDV el sitio de corte multibásico se identifica con las cepas virulentas (mesogénicas y velogénicas), que pueden diseminarse fácilmente por distintos tejidos del huésped. Las cepas con un único resíduo básico son las avirulentas o lentogénicas, ya que se ven restringidas a órganos o tejidos donde puedan procesarse, como el tracto respiratorio (Lamb y Parks, 2007; Nagai y Klenk, 1977). 


\section{4.- LA GENÉTICA INVERSA Y LA VIROLOGÍA MOLECULAR}

A pesar de su aparente simplicidad, los virus son en realidad entidades biológicas complejas que han desarrollado evolutivamente eficientes mecanismos para infectar células, expresar sus genomas y generar múltiples copias de sí mismos. Este hecho, el mismo que los ha convertido en una amenaza de primer orden para sus hospedadores, puede volverse beneficioso si se dispone de herramientas para controlar tales propiedades. El desarrollo de las técnicas del DNA recombinante ha suministrado en el último medio siglo esas herramientas, aumentando exponencialmente el conocimiento que se posee acerca de los virus, nuestra capacidad de actuar contra ellos, y en última instancia la posibilidad de utilizarlos en nuestro propio beneficio.

Tabla 1.3. Ingenieria genética en virus animales

DNA y RNA(+) (adaptado de Palese et al., 1996).

\begin{tabular}{|c|c|c|}
\hline Tipo de genoma & Virus más representativos & Estrategias \\
\hline DNA doble cadena & SV40, herpes, adenovirus, poxvirus & $\begin{array}{l}\text { Transfección de cDNA. } \\
\text { Recombinación homóloga usando } \\
\text { cDNA y DNA vírico intacto o virus } \\
\text { helper. Transfección con cósmidos }\end{array}$ \\
\hline $\begin{array}{l}\text { DNA cadena } \\
\text { sencilla }\end{array}$ & Virus adeno-asociados & Transfección con plásmidos \\
\hline \multirow{2}{*}{$\begin{array}{l}\text { RNA cadena } \\
\text { sencilla, polaridad } \\
\text { positiva }\end{array}$} & Retrovirus & Transfección con cDNA infeccioso \\
\hline & $\begin{array}{l}\text { Picornavirus, virus del bosque de Semliki, } \\
\text { virus Sindbis }\end{array}$ & $\begin{array}{c}\text { Transfección con cDNA infeccioso o } \\
\text { RNA derivado de él. }\end{array}$ \\
\hline
\end{tabular}

El concepto de genética inversa (del inglés reverse genetics) aplicado a la virología molecular describe la posibilidad de actuar in vitro sobre el material genético de los virus, obteniéndolo y modificándolo mediante técnicas de biología molecular, y la capacidad posterior de, a partir de ése material genético, obtener virus perfectamente viables pero fenotípicamente alterados de forma específica. Es por tanto la generación de virus que poseen un genoma derivado de cDNA clonado. Este proceso, generalmente denominado "rescate", comenzó a ser desarrollado hace tres décadas en virus con el genoma constituido por DNA, para pasar después a aplicarse a virus RNA(+) (ver Tabla 
1.3) y por último, como se comenta a continuación, a virus RNA(-). Gracias a esto no sólo ha mejorado sensiblemente nuestro conocimiento de la biología de los virus, sino que se han revelado multitud de perspectivas relacionadas con ellos.

\subsection{1.- DESARROLLO DE LA GENÉTICA INVERSA EN VIRUS RNA(-).}

El material genético de los virus RNA(-), al no poder transcribirse ni traducirse directamente, no es infeccioso por sí sólo, salvo que esté formando RNPs. Esta diferencia sustancial con respecto a los otros tipos de virus hizo que los sistemas de genética inversa para este grupo tardaran más en desarrollarse.

Los primeros avances se produjeron con ortomixovirus, virus con genomas segmentados. En 1989, Luytjes et al, trabajando con el virus de la gripe, establecieron el primer sistema para la modificación de virus RNA(-) (Figura 1.10A). El cDNA del gen de la cloranfenicol acetiltransferasa (CAT) fue clonado en sentido negativo entre secuencias 5'y 3' víricas no codificantes, bajo promotor de la polimerasa del fago T7. Por transcripción in vitro se obtuvo un RNA de polaridad negativa similar al vírico, que se mezcló con nucleoproteínas purificadas para constituir complejos RNP. Estos complejos se transfectaron en células previamente infectadas por un virus helper (en inglés, "ayudante"), y se rescataron viriones de gripe que además de los ocho segmentos genómicos normales (los suministrados por el helper) llevaban un noveno con la secuecia para CAT. Poco después se conseguía la primera mutación de un gen del virus de la gripe utilizando el mismo método (Enami et al, 1990). Este sistema adolece de dos desventajas: en primer lugar, el tedioso proceso previo necesario para sintetizar in vitro las RNPs y la problemática transfección de complejos tan grandes; en segundo lugar, la utilización de un virus helper hace necesario un proceso de selección para la población de virus rescatados que discrimine a aquel de los recombinantes.

Las desventajas de los sistemas puestos a punto con ortomixovirus se resolvieron para los Mononegavirales al desarrollarse un sistema basado únicamente en plásmidos transfectantes para el rescate de los mismos. Para estos virus con genomas no segmentados y con un tamaño superior a $11 \mathrm{~Kb}$ no cabía la posibilidad de producir una encapsidación in vitro, probablemente por tener unas RNPs altamente estructuradas (Baudin et al., 1994; Iseni et al., 1998; Mavrakis et al., 2002). Así, la única posibilidad era que el proceso se produjera dentro de la célula tras suministrar a ésta la materia prima necesaria. Éstas técnicas fueron precedidas por el estudio de los requisitos 
proteicos que el RNA vírico necesitaba para su amplificación, empleando como modelos los paramixovirus SeV (Park et al., 1991) y RSV (Collins et al., 1991). Para ello, la polimerasa de T7 expresada por un virus vaccinia recombinante (Fuerst et al., 1986) se empleó para sintetizar en células de cultivo RNA de polaridad negativa derivado del cDNA de minigenomas víricos (ver apartado 1.2.4.3). La infección de esas mismas células con un virus helper permitió recuperar partículas víricas con esos RNAs incompletos, lo que demostraba que la complementación en trans permitía la replicación del minigenoma. La determinación exacta de cuáles de los genes eran necesarios para dicha complementación se logró gracias a sucesivos experimentos de cotransfección con genomas incompletos y distintos plásmidos que expresaban individualmente las proteínas del virus bajo control de T7. Así se llegó a la conclusión de que, para paramixovirus y rabdovirus, eran necesarias la polimerasa L, la nucleoproteína N o NP y la fosfoproteína P (Pattnaik y Wertz, 1990; Collins et al., 1991; Conzelmann et al., 1991; Park et al., 1991; Calain et al., 1992; Dimock y Collins, 1993; Sidhu et al., 1995). Gracias al mismo tipo de estudios se descubrieron los requisitos de los restantes grupos de virus RNA(-): para los filovirus Marburg y Ebola (Muhlberger et al., 1998; Muhlberger et al., 1999); para bunyavirus (Dunn et al., 1995); arenavirus (Lee et al., 2000), y los ortomixovirus de la gripe (Honda et al., 1987, 1988; Honda et al., 1990; Szewczyk et al., 1988; Parvin et al., 1989). Los experimentos con los minigenomas permitieron también conocer otros requerimientos básicos para el rescate de virus RNA(-): el extremo 3' representando el promotor vírico debe estar al final de la cadena del transcrito; no puede funcionar desde una secuencia interna. Por el contrario, el extremo 5' puede tolerar la adición de nucleótidos adicionales (Collins et al., 1991; De y Banerjee., 1993). De hecho, este tipo de experimentación es la herramienta ideal para el estudio de los reguladores víricos en cis descritos en el apartado 1.2.3.2 (revisado por Whelan et al., 2004).

En 1994, gracias al conocimiento que los estudios citados arriba habían aportado, Schnell et al lograron con éxito construir un plásmido que expresara bajo promotor de T7 el RNA completo (full length) del antigenoma del virus de la rabia (RV), de la familia Rhabdoviridae. Por transfección conjunta de ese full length junto a plásmidos codificantes de las proteínas $\mathrm{L}, \mathrm{N}$ y $\mathrm{P}$ en células previamente infectadas con virus vaccinia expresando la polimerasa de T7, consiguieron por primera vez rescatar virus RNA(-) a partir de un sistema basado únicamente en plásmidos (Figura 1.10B). La 
clave de este sistema fue la utilización del RNA antigenómico, en sentido positivo, y no del RNA genómico, antisentido. Si se hubiera usado este último, los mRNA para las proteínas N, L y P habrían hibridado con el mismo e interferido con la generación de los viriones, evitando la formación de las nucleocápsidas. Otro inconveniente de la formación de dobles cadenas de RNA es la posible inducción del sistema del interferón en la célula transfectada (revisado por Basler y García-Sastre, 2002). Además, los RNAs genómicos de algunos virus RNA(-) contienen elementos que se asemejan a la señal terminadora para la polimerasa de T7, lo que podría provocar una interrupción temprana de la transcripción. Comenzando por el transcrito antigenómico, este RNA puede formar sin interferencia RNPs junto a las nucleoproteínas producidas por los cDNAs cotransfectantes y, una vez que se han formado, la cadena positiva puede replicarse por el complejo polimerasa también cotransfectante y formar genomas RNA(). A medida que éstos se van produciendo van asociándose con más nucleoproteínas, de forma que tampoco en ese momento puede producirse interferencia por los mRNA complementarios. Una vez que se dispone de RNPs genómicas funcionales, puede iniciarse un ciclo de infección normal (Figura 1.11). Un problema de este sistema es que no es fácil obtener la primera encapsidación del RNA desnudo con las nucleoproteínas, algo que el virus no debe nunca afrontar en su ciclo natural, y es probablemente por esta encapsidación "ilegítima” por lo que la eficiencia del proceso de rescate no es muy alta.

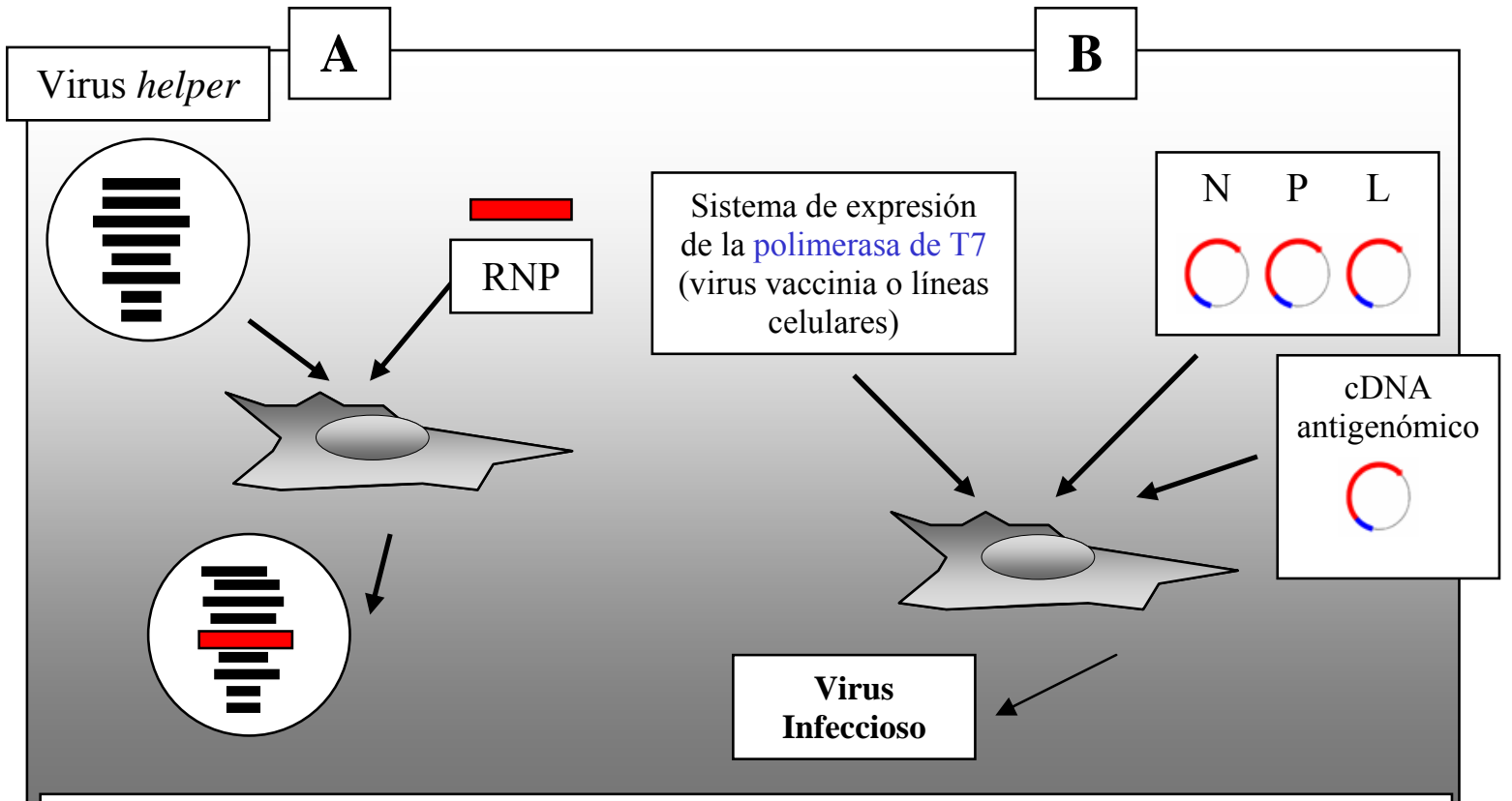

Figura 1.10. Evolución del rescate de virus RNA(-). A.- Rescate de virus de la gripe recombinantes por reconstitución in vitro de RNPs y cotransfección con un virus helper.( Luytjes et al., 1989) B.- Rescate de virus RNA(-) no segmentados a partir de plásmidos (Schnell et al., 1994). Adaptado de Palese et al., 1996. 
Desde el trabajo de Schnell et al en 1994 se han producido, empleando el mismo sistema, un gran número de rescates de virus RNA(-) de genoma no segmentado (revisado por Palese et al., 1996; Roberts y Rose, 1998; García-Sastre, 1998; Conzelmann, 2004). Las técnicas se han aplicado con éxito a distintos virus pertenecientes a las familias Rhabdoviridae y Paramyxoviridae a los que se sumaron el filovirus Ebola (Volchkov et al., 2001; Neumann et al., 2002a) y, más recientemente, los bornavirus (Schneider et al., 2005), con lo que todas las familias del orden Mononegavirales tienen sistemas de genética inversa bien definidos. También se han hecho intentos comparativos de rescate empleando el RNA genómico en lugar del antigenómico, demostrándose su inviabilidad (Lawson et al., 1995; Whelan et al., 1995; Radecke et al., 1995) salvo en pocos casos en que la eficiencia del proceso fue ínfima (Kato et al., 1996; Durbin et al., 1997).

Los éxitos en Mononegavirales pronto se transmitieron al estudio de los virus con genoma segmentado, primero en bunyavirus (Bridgen y Elliot, 1996), con el genoma constituido por tres segmentos, siguiendo el mismo enfoque que Schnell et al. Para el virus de la gripe A, el sistema requirió un mayor refinamiento al implicar ocho segmentos genómicos, pero finalmente se pudieron rescatar virus partiendo únicamente de baterías de 12 plásmidos (Neumann et al., 1999; Fodor et al., 1999); ocho para los RNA genómicos y 4 para los componentes de la polimerasa. La clave fue la utilización de promotores para la RNA polimerasa I (PolI), presente en el nucleolo y que produce RNAs sin adiciones ni en $5^{\prime}$ ni en $3^{\prime}$, al igual que los producidos por la polimerasa vírica. Posteriores revisiones de la técnica han conducido a rescates exitosos partiendo de ocho plásmidos (Hoffmann et al., 2000; Hoffmann y Webster, 2000), empleando moldes que codificaran al mismo tiempo tanto para mRNAs subgenómicos como para el RNA genómico. Dado que la replicación de los virus de la gripe tiene lugar en el interior del núcleo celular y que, por tanto, no se puede producir un acoplamiento entre RNAs complementarios, en este sistema se obtienen los mismos resultados partiendo de RNA genómico o antigenómico. Finalmente, el sistema del rescate de gripe A ha llegado a evolucionar hasta reducir sus componentes a un sólo plásmido (Neumann et al., 2005) o a emplear la polimerasa de T7 en lugar de PolI (de Wit et al., 2007), ampliando así el rango de especies de cuyas células pueda rescatarse el virus, antes limitado por la especificidad de los promotores de PolI. 


\subsection{2.- MANIPULACIÓN GENÉTICA DEL NDV.}

Como con el resto del orden Mononegavirales, en los últimos años han comenzado a aplicarse las técnicas de la genética inversa al NDV con distintos objetivos, siguiendo, con más o menos modificaciones, los procedimientos descritos para otros virus de genoma RNA(-) no segmentado. En 1999, Peeters et al. clonaron el cDNA antigenómico completo, o full length, del NDV de la cepa lentogénica La Sota flanqueado por el promotor de T7 y por la ribozima del virus de la hepatitis delta (HDV), que permite que el extremo $3^{\prime}$ del transcrito primario sea el mismo que el del antigenoma vírico original. A partir de esta construcción, y siguiendo un procedimiento similar al descrito por Schnell et al. en 1994 para RV, consiguieron por primera vez rescatar NDV infectivo a partir de plásmidos con cDNA. Esta técnica la emplearon para modificar la secuencia aminoacídica diana del procesamiento proteolítico de la proteína F, demostrando que es un factor determinante de la virulencia del virus. Simultáneamente a la publicación de los resultados de Peeters y colaboradores, RömerOberdörfer et al. (1999) describieron el rescate de virus de la cepa lentogénica Clone 30 según un procedimiento similar, si bien en este último caso se emplearon células con una transfección estable de la polimerasa de T7 en vez de un vector vírico, como había hecho el grupo de Peeters. Pese a ligeras modificaciones como ésta, el sistema de rescate del NDV, esquematizado en la Figura 1.11, se ha mantenido básicamente igual durante los últimos diez años, permitiendo nuevas aproximaciones en el estudio o utilización del NDV y el rescate de cepas no sólo lentogénicas, sino también mesogénicas y velogénicas. La tabla 1.4 resume los trabajos en los que se ha descrito la generación de nuevos NDV recombinantes por técnicas de genética inversa en los últimos diez años. A grandes rasgos, pueden clasificarse estos trabajos en tres grandes grupos: los que estudian los factores de la virulencia del NDV, los que estudian su uso como vector de vacunación y los que estudian su uso como agente antitumoral. Además, algunos de los virus rescatados han sido utilizados como herramientas en otras vías de investigación no relacionadas directamente con el NDV, especialmente como componentes de bioensayos para el estudio de proteínas víricas antagonistas del sistema de interferón, tales como las proteínas V, W y C del virus Nipah (Park et al., 2003a) y la proteína NS1 de gripe A (Mibayashi et al., 2007) 


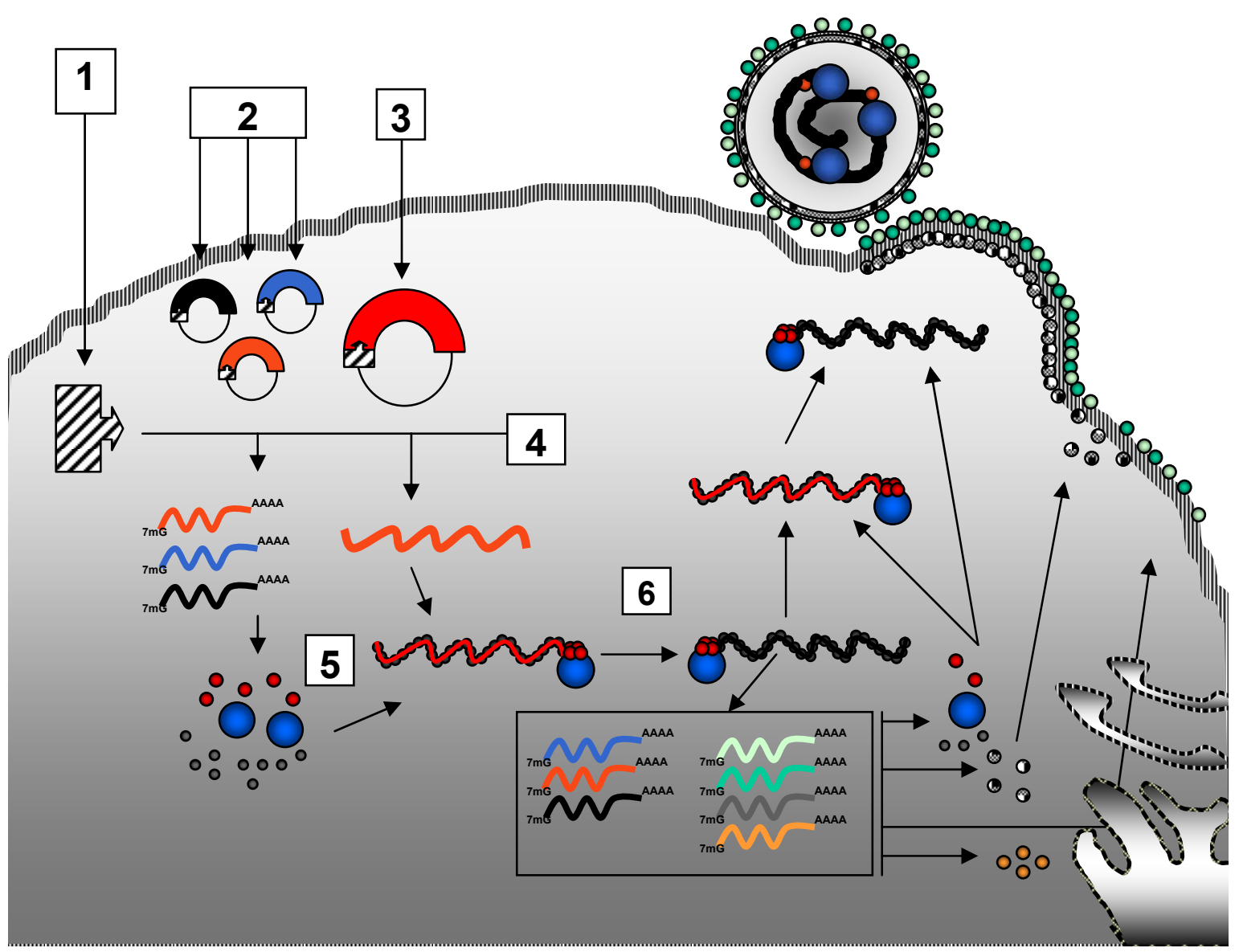

Figura 1.11. Rescate del NDV. 1.- Sistema de expresión de la polimerasa de T7 (virus vaccinia o línea celular). 2.- Transfección con plásmidos con NP, P, L y el (3.-) cDNA full-length. 4.- Transcripción a partir del promotor de T7. 5.Constitución de las RNPs antigenómicas. 6.- Inicio de un ciclo replicativo normal.

\subsubsection{1.- Estudio de los factores de virulencia y propagación del NDV.}

La posibilidad de estudiar cambios puntuales en alguno de los genes del virus en el contexto de una infección real permitió que con los NDV recombinantes comenzaran a definirse claramente los factores que determinan la virulencia del virus. Estaba establecido que el factor clave en dicha virulencia se trataba de la secuencia de corte proteolítico del precursor $\mathrm{F}_{0}$ (apartado 1.3.5). Así, como mencionamos antes, la proteína de fusión de las cepas lentogénicas únicamente podría activarse en tejidos que expresaran proteasas tipo tripsina, limitando el alcance de la infección frente a las cepas virulentas (mesogénicas o velogénicas), cuya secuencia de corte proteolítico polibásico las hacía dianas de la ubícua familia de proteasas tipo furina. Esta hipótesis 


\begin{tabular}{|c|c|c|}
\hline \multicolumn{3}{|c|}{ TABLA 1.4.- ESTUDIOS CON RESCATES DE rNDV } \\
\hline CEPA & AUTORES & MODIFICACIONES/INSERTOS \\
\hline La Sota (L) & Peeters et al. (1999) & Sitio proteolítico $\mathrm{F}_{0}$ \\
\hline Clone $30(\mathrm{~L})$ & $\begin{array}{c}\text { Römer-Oberdörfer et al. } \\
\text { (1999) }\end{array}$ & ninguno \\
\hline Beaudette C (M) & Krishnamurthy et al. (2000) & CAT \\
\hline La Sota $(\mathrm{L})$ & Peeters et al. (2001) & $\begin{array}{c}\text { Susitución HN por híbrido HN/HN de paramixovirus } \\
\text { aviar tipo } 4\end{array}$ \\
\hline Clone $30(\mathrm{~L})$ & Mebatsion et al. (2001) & Sitio edición $\mathrm{P} / \mathrm{V}$ \\
\hline La Sota (L) & Huang et al. (2001) & CAT \\
\hline Hitchner B1 (L) & Nakaya et al. (2001) & HA gripe $\mathrm{A} / \mathrm{WSN} / 33$ \\
\hline Clone $30(\mathrm{~L})$ & Mebatsion et al. (2002) & Sustitución epítopo inmunodominante en NP \\
\hline Hitchner B1 (L) & Park et al. (2003a) & GFP \\
\hline La Sota (L) & De Leeuw et al. (2003) & Sitio proteolítico $\mathrm{F}_{0}$ \\
\hline Clone $30(\mathrm{~L})$ & Engel-Herbert et al. (2003) & GFP \\
\hline La Sota (L) & Zhao y Peeters., (2003) & SEAP (fosfatasa alcalina secretada) \\
\hline Clone $30(\mathrm{~L})$ & $\begin{array}{l}\text { Römer-Oberdörfer et al. } \\
\text { (2003) }\end{array}$ & Sitio proteolítico $\mathrm{F}_{0}$. Codón de terminación $\mathrm{HN}$ \\
\hline Beaudette C (M) & Huang et al. (2003b) & Sitio edición $\mathrm{P} / \mathrm{V} / \mathrm{W}$ \\
\hline Hitchner B1 (L) & Park et al. (2003b) & NS1 gripe. Edición $\mathrm{P} / \mathrm{V}$ \\
\hline Clone $30(\mathrm{~L})$ & Mebatsion et al. (2003) & Sitio edición $\mathrm{P} / \mathrm{V} / \mathrm{W}$ \\
\hline Hitchner B1 (L) & Swayne et al. (2003) & HA gripe aviar A/chicken/NY/13142-5/94 (H7N2) \\
\hline La Sota $(\mathrm{L})$ & Al Garib et al. (2003) & GFP \\
\hline La Sota (L) & Panda et al. (2004a) & Sitio proteolítico $\mathrm{F}_{0}$ \\
\hline $\begin{array}{l}\text { Beaudette C (M), } \\
\text { La Sota }(\mathrm{L}) \\
\end{array}$ & Huang et al. (2004a) & Intercambio $\mathrm{HN}$ \\
\hline Beaudette C (M) & Panda et al. (2004b) & Mutación sitios N-glicosilación HN \\
\hline Hitchner B1 (L) & Nakaya et al. (2004) & SIV gag \\
\hline La Sota (L) & Huang et al. (2004b) & IBDV VP2 \\
\hline La Sota (L) & Peeters et al. (2004) & Codón de iniciación putativo de $\mathrm{X}$ \\
\hline Beaudette C (M) & Bousse et al. (2004) & $\begin{array}{c}\text { Sustitución HN (cepa Kansas). Mutación segundo sitio } \\
\text { receptor. } \\
\end{array}$ \\
\hline Herts/33 (V) & De Leeuw et al. (2005) & Intercambio secuencias F y HN (Herts/33-La Sota) \\
\hline La Sota $(\mathrm{L})$ & Bian et al. (2005) & EGFP \\
\hline $\begin{array}{l}\text { Beaudette C (M), } \\
\text { La Sota }(\mathrm{L}) \\
\end{array}$ & Bukreyev et al. (2005) & hPIV3 HN \\
\hline Hitchner B1 (L) & Martínez-Sobrido et al. (2006) & RSV F \\
\hline Hitchner B1 (L) & Park et al. (2006) & $\begin{array}{l}\text { Sitio proteolítico } \mathrm{F}_{0} \text { (F3aa y F2aa). HA gripe aviar } \\
\text { A/chicken/NY/13142-5/94 (H7N2). Quimera HN/H7 }\end{array}$ \\
\hline
\end{tabular}




\begin{tabular}{|c|c|c|}
\hline CEPA & AUTORES & MODIFICACIONES/INSERTOS \\
\hline Clone $30(\mathrm{~L})$ & Veits et al. (2006) & HA gripe aviar A/chicken/Italy/8/98 (H5N2) \\
\hline Clone $30(\mathrm{~L})$ & $\begin{array}{l}\text { Römer-Oberdörfer et al. } \\
\text { (2006) }\end{array}$ & Sitio proteolítico $\mathrm{F}_{0}$. Mutaciones $\mathrm{HN}$ \\
\hline Beaudette C (M) & Elankumaran et al. (2006) & EGFP. Sitio edición P/V \\
\hline Hitchner B1 (F3aa) & Mibayashi et al. (2007) & mRFP \\
\hline La Sota (L) & Ge et al. (2007) & $\begin{array}{l}\text { HA gripe aviar A/Bar-headed } \\
\text { goose/Qinghai/3/2005/(H5N1) }\end{array}$ \\
\hline ZJ1 (V) & Liu et al. (2007) & GFP \\
\hline $\begin{array}{l}\text { Beaudette C }(\mathrm{M}) \\
\text { La Sota }(\mathrm{L})\end{array}$ & Di Napoli et al. (2007a) & SARS CoV S/S1 \\
\hline Anhinga (M) & Estevez et al. (2007) & $\begin{array}{c}\text { Combinaciones F y HN de cepas velogénicas CA02 y } \\
\text { TkND }\end{array}$ \\
\hline $\begin{array}{l}\text { Hitchner B1 (L) } \\
\text { (F3aa) }\end{array}$ & Vigil et al. (2007) & $\begin{array}{c}\text { Luciferasa, fragmento } \beta \text {-galactosidasa, GM-CSF, IFN- } \\
\gamma, \text { IL-2, TNF } \alpha .\end{array}$ \\
\hline La Sota $(\mathrm{L})$ & Janke et al. (2007) & GM-CSF \\
\hline Beaudette C (M) & Di Napoli et al. (2007b) & HA gripe aviar A/Vietnam/1203/2004 (H5N1) \\
\hline MTH68 (M) & Pühler et al. (2008) & EGFP. Cadenas ligera y pesada IgG (2 insertos) \\
\hline Clone $30(\mathrm{~L})$ & $\begin{array}{l}\text { Veits et al. (2008). Römer- } \\
\text { Oberdörfer et al. (2008) }\end{array}$ & HA gripe aviar A/chicken/Italy/8/98 (H5N2) \\
\hline Beaudette C (M) & Yan y Samal, (2008) & Cambios en secuencias intergénicas \\
\hline Hitchner B1 (F3aa) & Gao et al. (2008) & Genoma en dos segmentos. GFP, dsRed, SARS CoV S. \\
\hline La Sota $(\mathrm{L})$ & Zhao et al. (2008) & IL-2 \\
\hline Hitchner B1 (F3aa) & Vigil et al. (2008) & $\begin{array}{c}\text { Fragmento } \beta \text {-galactosidasa, antígeno asociado a tumor } \\
\text { (TAA) }\end{array}$ \\
\hline $\begin{array}{l}\text { Beaudette C (M), } \\
\text { La Sota }(\mathrm{L})\end{array}$ & Rout y Samal, (2008) & Intercambios $\mathrm{P}, \mathrm{NP}$ y $\mathrm{L}$ \\
\hline Hitchner B1 (L) & Carnero et al. (2008) & HIV gag \\
\hline ZJ1 (V) & Hu et al. (2008) & Sitio proteolítico $\mathrm{F}_{0}$. Sustitución HN por cepa JS5 (V) \\
\hline
\end{tabular}

Se indican en negrita los rescates que implican la clonación original del cDNA completo de las distintas cepas. (L): cepa lentogénica. (M): cepa mesogénica. (V): cepa velogénica. Se agrupan por colores los distintos bloques de objetivos con los que se rescataron los virus de la siguiente manera:

- Estudios relacionados con los factores de virulencia y propagación natural del virus (especialmente $\mathrm{F}, \mathrm{HN}$ y $\mathrm{P} / \mathrm{V}$ )

- Estudios del NDV como vector de vacunación.

- Estudios del NDV como agente antitumoral.

- Otros (descripción de nuevos rescates, evaluación de la presencia de insertos en el genoma del NDV o utilización como herramienta en el estudio de otros virus). 
se ha comprobado al construir rNDVs con las secuencias de corte intercambiadas: cepas lentogénicas con secuencias consenso de las virulentas (Peeters et al., 1999; RömerOberdörfer et al. 2003; Panda et al., 2004a; Park et al. 2006) muestran mayor virulencia que el fenotipo parental, mientras que a la inversa se obtiene atenuación ( $\mathrm{Hu}$ et al., 2008). Sin embargo, al introducir una secuencia de corte de una cepa virulenta en otra lentogénica esta última sigue siendo atenuada en comparación con la primera. Este descubrimiento llevó a la búsqueda de un modelo multigénico que explicase la virulencia del NDV.

Las proteínas no estructurales del NDV, V, W y la hipotética X, no pudieron estudiarse funcionalmente hasta que no se dispuso de las técnicas de genética inversa adecuadas. La modificación del sitio de edición de $\mathrm{P}$ para que se expresaran menores niveles de $\mathrm{V}$ dio como resultado un rNDV altamente atenuado en huevos (Mebatsion et al., 2001), con lo que V comenzó a perfilarse como otro de los factores de virulencia del virus. Posteriores estudios establecieron V como antagonista del sistema de interferon, localizando esta actividad en su dominio C-terminal rico en cisteínas, en el que difiere de P (Park et al., 2003a). Esta acción la llevaría a cabo induciendo la degradación de STAT1 (Huang et al., 2003b), al igual que hacen las proteínas V de PIV5 y del virus de las paperas. La proteína $\mathrm{V}$ también se definió como clave en la determinación del rango de hospedador del virus, ya que únicamente restringe el sistema del interferón en células de ave, no en humanas (Park et al., 2003b). Estudios en los que se también se ha empleado el rescate de virus recombinantes han negado la existencia de una proteína $\mathrm{X}$ en el NDV (Peeters et al., 2004). En cuanto a W, ninguno de los trabajos que han tratado sobre ella hasta el momento (Huang et al., 2003b; Mebatsion et al., 2003) han conseguido atribuirle ninguna importancia o actividad funcional.

Junto a $\mathrm{F}$ y $\mathrm{V}$, un tercer candidato obvio para establecer los distintos grados de virulencia de las cepas del NDV es la proteína $\mathrm{HN}$, en su triple papel de reconocimiento del receptor, neuraminidasa y promotora de fusión. El intercambio recíproco de HN entre cepas mesogénicas y lentogénicas ha supuesto ganancia o pérdida de patogenicidad y un cambio en la distribución tisular del virus en modelos en los que las proteasas que procesan F no son limitantes (esto es, el embrión de pollo en su huevo) (Huang et al., 2004a). Igualmente se ha demostrado que en la participación de $\mathrm{HN}$ en la virulencia participan tanto la cabeza globular como el tallo (de Leew et al., 2005). Otros rescates de virus recombinantes con sus $\mathrm{HN}$ alteradas han demostrado la importancia de la N-glicosilación (Panda et al., 2004a) y del segundo sitio de reconocimiento del 
receptor (Bousse et al., 2004), afectando en ambos casos la actividad promotora de fusión. Si bien determinadas $\mathrm{HN}$ velogénicas pueden mejorar el crecimiento en huevos de virus recombinantes (Hu et al., 2008), su inclusión en un genotipo mesogénico no basta para conferirle fenotipo velogénico (Estevez et al., 2007).

Otros estudios con virus recombinantes relativos a los factores de virulencia del NDV han girado en torno a los mecanismos por los que promueve apoptosis (Elankumaran et al., 2006) o la retrasa en determinados hospedadores (Park et al., 2003b). El tamaño de las secuencias intergénicas (Yan y Samal, 2008) y más recientemente un estudio sobre el posible papel de la polimerasa L (Rout y Samal, 2008), completan la serie de trabajos centrados en este tema. Todo lo descubierto hasta el momento resalta la multigenicidad de la virulencia del NDV, si bien destacando en todo momento que el factor fundamental es la proteína de fusión y su procesamiento adecuado.

\subsubsection{2.- Estudios del NDV como vector de vacunación.}

Habitualmente, la vacuna de elección frente a un patógeno vírico es una forma atenuada del mismo. Sin embargo, no siempre puede conseguirse una vacuna así: no cabe plantearse, por ejemplo, con virus como el HIV, por su infección persistente; o con el Ebola, por su extrema virulencia. Otros virus no pueden crecerse adecuadamente in vitro, como el virus de la hepatitis C; son fisicamente inestables, como el RSV; demasiado peligrosos para la manipulación, como el mismo Ebola o el coronavirus del SARS, o pueden intercambiar fragmentos con virus silvestres circulantes, como los virus de la gripe o los coronavirus. Por todo ello, desde que en 1983 Smith, Mackett y Moss construyeron un virus vaccinia recombinante con antígenos foráneos $\mathrm{y}$ demostraron su capacidad para inducir inmunidad, han venido desarrollándose vectores víricos de vacunación de forma paralela al avance de las técnicas del DNA recombinante. Con los sistemas de genética inversa, esta posibilidad práctica se abrió también para los virus RNA(-), y entre ellos para el NDV (Bukreyev et al., 2006).

El NDV comparte varias ventajas con sus parientes RNA de polaridad negativa a la hora de plantearlos como posibles vectores de vacunación (Bukreyev et al., 2006, Huang et al., 2003a). Puede replicarse fácilmente hasta títulos muy altos en huevos y diferentes líneas celulares, facilitando el proceso de generación y producción de vacunas. No tiene estadio de DNA en su ciclo biológico y por tanto no puede integrarse 
en el genoma del hospedador. El genoma del NDV es relativamente simple y con una organización modular que facilita su manipulación: se conocen bien los reguladores en cis que lo controlan y se ha demostrado que puede incorporar insertos foráneos y expresarlos establemente durante numerosos pases. Esta misma cualidad permite el diseño de vectores "prefabricados", en los que pueda introducirse rápidamente un antígeno de interés en poco tiempo sobre un trasfondo ya evaluado con anterioridad: una posibilidad de gran importancia ante el riesgo de patógenos emergentes y potencialmente pandémicos. Finalmente, el nivel de expresión del antígeno recombinante puede modificarse variando su posición en el genoma del vector y, como vimos en el apartado anterior, cabe la posibilidad de modificar la virulencia de la vacuna y su rango de infección. Además de todas estas ventajas, el NDV no es un patógeno humano como se ha comentado anteriormente, los síntomas ante una infección varían entre los de una gripe suave y una conjuntivitis moderada. La población, en general, no presenta memoria inmunológica preexistente contra el virus y, en cualquier caso, la existencia de otros siete serotipos de paramixovirus aviar y la posibilidad de modificar por genética inversa la antigenicidad del NDV podrían solventar este problema.

El NDV es un importante patógeno aviar y la vacunación contra el mismo tiene una gran importancia en las explotaciones avícolas de todo el mundo. Actualmente las vacunas consisten en cepas lentogénicas, especialmente La Sota y Hitchner-B1, pero desde los primeros rescates de NDV se postuló la posibilidad de mejorarlas, disminuyendo la virulencia del virus (Peeters et al., 1999, Hu et al., 2008), permitiendo la distinción serológica entre animales vacunados e infectados (Peeters et al., 2001) o dotándolas de un carácter bivalente para que protegieran también contra otras enfermedades aviares (IBDV en Huang et al., 2004b, o gripe A, sobre la que trataremos más adelante). La generación de vacunas basadas en el NDV contra patógenos víricos humanos se ha evaluado modificando un epítopo antigénico de su propia NP (Mebatsion et al., 2002), pero la determinación de que el genoma de los virus recombinantes podía incorporar nuevos genes y en distintas posiciones (Krishnamurthy et al., 2000; Huang et al., 2001; Zhao y Peeters, 2003) permitió la inclusión de antígenos completos en el mismo. Así, se han rescatado NDV recombinantes con las proteínas HA de gripe A (Nakaya et al., 2001), gag de SIV (Nakaya et al., 2004), F de RSV (Martínez-Sobrido et al., 2006), S del coronavirus del SARS (Di Napoli et al., 2007a) y gag de HIV (Carnero et al., 2008). Se demostró que estos virus eran inmunogénicos en modelos murinos 
(Nakaya et al., 2001; Martínez-Sobrido et al., 2006; Di Napoli et al., 2007a) y también en primates, administrando por vía respiratoria rNDV con la HN de hPIV-3 (Bukreyev et al., 2005) o con la HA de gripe (Di Napoli et al., 2007b).

De todas las posibles aplicaciones del NDV como vector de vacunación, la referente a su uso contra la gripe aviar ha sido la más recurrente hasta el momento en la bibliografía científica. Como se muestra en la tabla 1.4, se han publicado hasta seis trabajos con virus recombinantes expresando los genes de distintas HA (H5 o H7) procedentes de virus de los brotes más recientes de gripe aviar. La posibilidad de inmunizar simultáneamente en las explotaciones avícolas contra el NDV y el virus de la gripe puede ser una estrategia útil para evitar la extensión de cepas altamente virulentas de este último y, en última instancia, el salto interespecífico a los seres humanos capaz de producir una nueva pandemia. De entre estos estudios, merece la pena destacar el publicado por Park et al. (2006), por la relevancia que tiene en la elaboración de la presente tesis doctoral. En este trabajo se modificó el sitio de procesamiento proteolítico de la proteína $\mathrm{F}$ de la cepa lentogénica de NDV Hitchner-B1 a una forma virulenta, generando el virus rNDV-F3aa. Sobre este soporte se rescataron virus expresando la proteína HA de gripe aviar A/chicken/NY/13142-5/94 (H7N2), en su forma nativa o bien en forma de quimera con el dominio extracelular de $\mathrm{H} 7$ y el intracelular de la proteína F del NDV. Los resultados mostraron que el rNDV-F3aa-H7 era capaz de inducir una inmunidad mayor en pollos que la inducida por el más atenuado rNDV-B1H7 (Swayne et al., 2003). El efecto protector fue aún mayor con el virus expresando la quimera $\mathrm{H} 7 / \mathrm{F}$, que se incorporaba con mucha mayor eficiencia a la membrana de los viriones recombinantes que la forma nativa, probablemente favoreciendo de esta manera la respuesta humoral. Además de como vector bivalente en aves, el rNDV con HA de gripe aviar ha sido también evaluado como vector de vacunación en primates (Di Napoli et al., 2007b).

Como consecuencia de las investigaciones para la generación de rNDV como vectores de vacunación, se ha podido profundizar en la influencia de la posición de un inserto foráneo en el genoma del virus sobre su expresión. En los estudios donde se han comparado distintos sitios de inserción (Zhao y Peeters, 2002; Carnero et al., 2008) se ha verificado básicamente el gradiente de expresíon 3'>5' propio de los paramixovirus, con la excepción de que la expresión del transgén desde la región entre NP y P es menor que entre otros genes aguas abajo, probablemente por perturbar la proporción de transcritos necesarios para cada producto. Otra valoración que puede extraerse de estos 
trabajos es que en la mayoría de los casos la presencia de un inserto atenúa el fenotipo parental, aunque de forma variable según estudios y cepas. El tamaño máximo de un transgén introducido en el NDV hasta la fecha lo fijan las 3768 pb de la proteína S del coronavirus del SARS (Di Napoli et al., 2007a), si bien este límite parece depender de la cepa. Dada la imposibilidad de rescatar virus con el mismo inserto con NDV Hitchner-B1, Gao et al. (2008) construyeron y rescataron el primer rNDV con el genoma dividido en dos segmentos, con el fin de poder introducir más y mayores secuencias.

Un aspecto que ha generado recientemente una cierta polémica en torno a las vacunas basadas en el NDV es la posibilidad de recombinación en el mismo; hecho que, de producirse, podría llevar a la presencia de virus silvestres con transgenes incorporados tras infecciones conjuntas con el virus vacunal. Lo cierto es que, si bien existen casos publicados de recombinación en el NDV, no ha quedado demostrado ni el que realmente sean eventos naturales y no artefactos de laboratorio ni el que sean significativos de lo que sucede en la naturaleza. Los recientes cruces de correspondencia en publicaciones de referencia (Han et al., 2008; Afonso, 2008; Collins et al., 2008) parecen coincidir, no obstante, en la necesidad de evaluar esta posibilidad, sin que ello suponga dejarse llevar por alarmismos innecesarios.

\subsubsection{3.- Estudios del NDV como agente antitumoral.}

En 1965, Cassel y Garrett describieron por primera vez el potencial antitumoral del NDV. El virus no es patológico en seres humanos, sin embargo puede replicarse y destruir selectivamente células tumorales respetando las sanas: esta inherente capacidad oncolítica, compartida con otros virus, se cree debida a los defectos en los sistemas antivíricos que presentan muchos tumores, especialmente el del interferón (IFN). Durante los últimos 40 años se han realizado estudios empleando el NDV como agente antitumoral, utilizando cepas mesogénicas circulantes en la naturaleza. Hasta el momento se han publicado estudios de casos (cepa MTH68, Csatary et al., 1993; Csatary et al., 2004) y ensayos clínicos (cepa PV701, Pecora et al., 2002; Lorence et al., 2007) con resultados prometedores. Las técnicas de genética inversa aplicadas a este campo permitieron en un principio el seguimiento del virus en la infección de células tumorales mediante la expresión de genes marcadores (Bian et al., 2005), pero pronto pasaron a utilizarse para potenciar la capacidad oncolítica del NDV. 
En consonancia con estudios anteriores (Bateman et al., 2002), se demostró que virus recombinantes con una proteína de fusión altamente fusogénica eran antitumorales más eficientes (Vigil et al., 2007, con el ya citado rNDV-F3aa. Figura 1.12). Esa eficiencia puede mejorarse aún más con la inclusión en el genoma de los virus de genes de citocinas inmunoestimulantes (Vigil et al., 2007; Puhler et al., 2007; Zhao et al., 2008). De hecho, estos estudios han llevado al descubrimiento de que en la respuesta antitumoral inducida por el NDV juega un papel importante la activación del sistema inmune por las células infectadas, y que esa activación puede ser favorecida con la expresión de epítopos antigénicos recombinantes (Vigil et al., 2008). Esta cualidad está en consonancia con la reconocida capacidad del NDV para generar una potente respuesta celular y humoral, demostrada en los ensayos de vacunación antes mencionados, y colabora con otras vías apoptóticas o no apoptóticas de destrucción celular.

Otra aproximación oncológica en el trabajo con NDV recombinantes es la posibilidad de que expresen anticuerpos completos contra determinados antígenos. A este fin se han conseguido rescatar rNDV con dos insertos, los correspondientes a la cadena ligera y la cadena pesada de una misma inmunoglobulina: la IgG completa pudo detectarse tras la infección en el sobrenadante de cultivos celulares (Puhler et al., 2008).

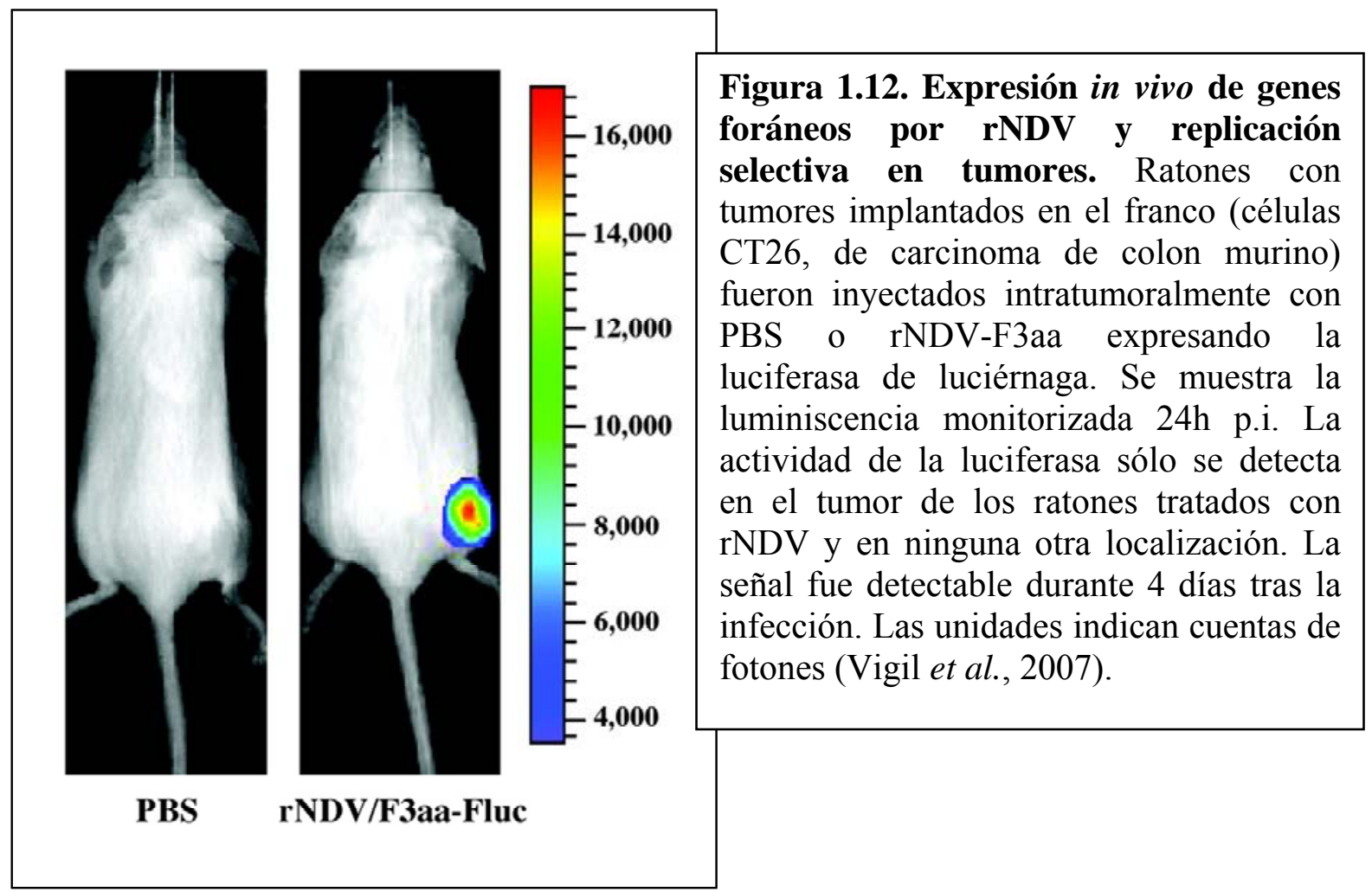




\section{5.- LA ENDOGLINA}

La endoglina, también conocida como antígeno de diferenciación 105 (CD105), es una glicoproteína homodimérica transmembrana tipo I de $180 \mathrm{kDa}$ compuesta por dos subunidades unidas por puentes disulfuro (Gougos y Letarte, 1988) (Figura 1.13). Fue originalmente identificada en el endotelio vascular humano donde se ha observado que se expresa en niveles altos (Gougos y Letarte, 1988). También se ha localizado en otros tipos celulares como macrófagos activados (Lastres et al.., 1992), trofoblastos, fibroblastos (St-Jacques et al., 1994), células de músculo liso vascular (Adam et al., 1998), o células mesangiales (Quackenbush et al., 1986; Rodríguez-Barbero et al., 2001).

\subsection{1.- ESTRUCTURA DE LA ENDOGLINA}

El gen que codifica la endoglina en la especie humana se encuentra en el brazo largo del cromosoma 9 (9p34) (Fernández-Ruiz et al., 1993) y contiene 15 exones, 13 de los cuales codifican para el dominio extracelular. La clonación del cDNA de endoglina demostró la existencia de dos isoformas diferentes, probable resultado de un procesamiento alternativo (Gougos y Letarte, 1990; Bellón et al., 1993). Las dos isoformas de endoglina se denominan, en función del número de aminoácidos de su estructura primaria, L-endoglina (endoglina larga), que presenta en su dominio citoplasmático 47 aminoácidos; y S-endoglina (endoglina corta), que sólo tiene 14 aminoácidos en él. Este dominio citoplasmático está constitutivamente fosforilado, lo que sugiere un posible papel en la señalización celular o una asociación con otras proteínas del citoplasma (Lastres et al., 1994). Esta hipótesis queda reforzada por el hecho de que endoglina une TGF- $\beta 1$, TGF- $\beta 3$, activina-A y BMP7 (Barbara et al., 1999; Cheifetz et al., 1992) con alta afinidad en presencia de los receptores señalizantes tipo I y II (Barbara et al., 1999; Letamendía et al., 1998a), formando complejos heteroméricos (Yamashita et al., 1994; Zhang et al., 1996). Las isoformas L- y Sendoglina son diferentes también en el nivel de fosforilación (Lastres et al., 1994), pero ambas son capaces de unir TGF- $\beta 1$ y regular sus respuestas celulares (Bellón et al., 1993; Lastres et al., 1996). La región extracelular de endoglina (Figura 1.13) se encuentra altamente glicosilada: los oligosacáridos, unidos a la cadena peptídica tanto 
por enlaces N- como O-glicosídicos, constituyen aproximadamente el 20\% del peso total de la proteína (Gougos y Letarte, 1988). La región extracelular también presenta un motivo RGD (arginina-glicina-aspartato), un sitio de reconocimiento para integrinas que se ha encontrado en otras proteínas de la matriz extracelular como la fibronectina, vitronectina, factor von Willebrand, colágeno I y fibrinógeno. Por esta razón se ha sugerido que endoglina podría ser un posible ligando de integrinas y estar relacionada con fenómenos de adhesión celular, aunque hasta el momento no ha podido demostrarse (Gougos y Letarte, 1990; Lastres et al., 1992).

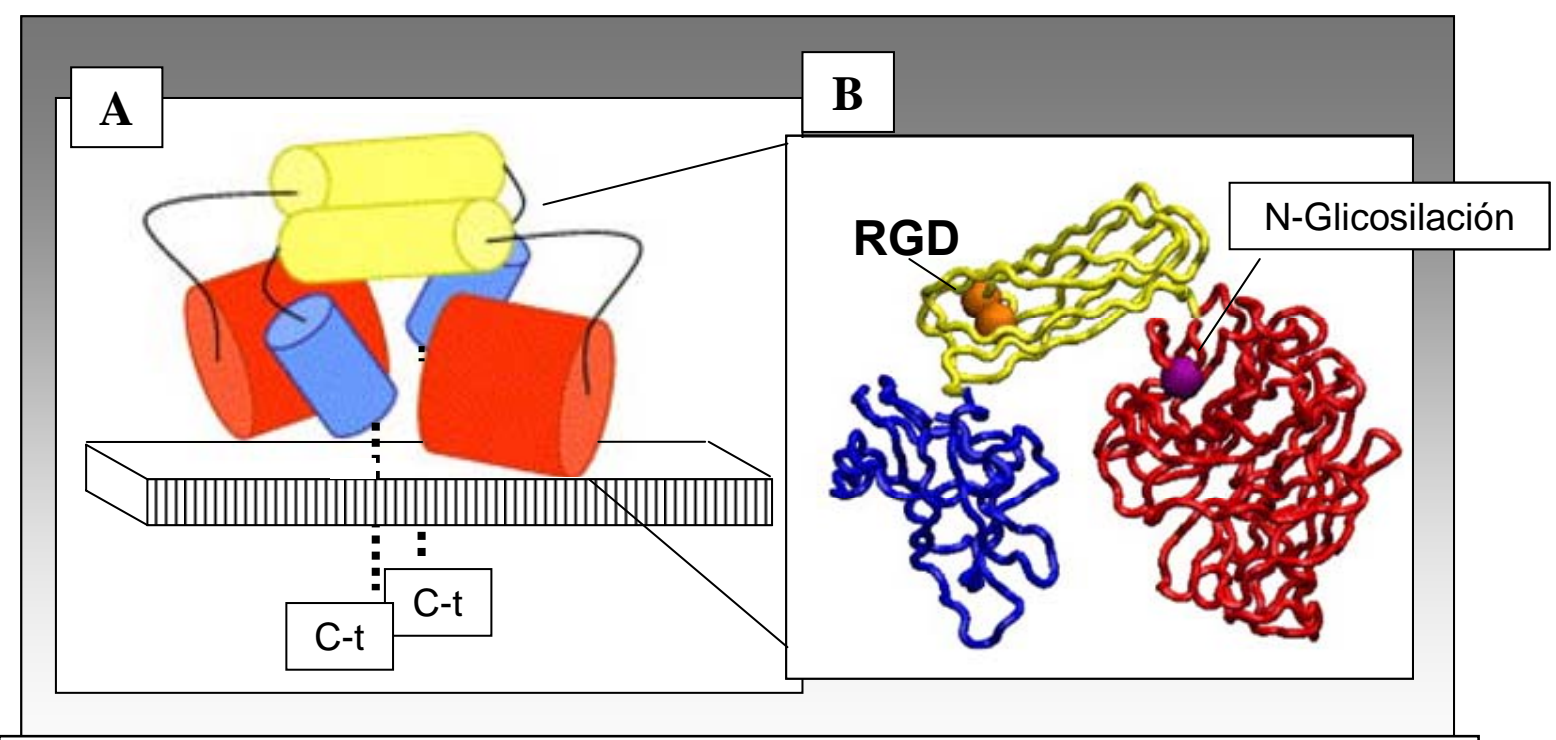

Figura 1.13. Estructura de la endoglina. (A).- Reconstrucción tridimensional de la región extracelular del dímero de endoglina, obtenida a partir de una forma recombinante secretada analizada por microscopía electrónica. Se muestra la posición del dímero con respecto a la membrana plasmática y la teórica orientación del extremo C-terminal. (B).- Dominios extracelulares de un monómero de endoglina. Se indican las posiciones del motivo RGD y de uno de los sitios de Nglicosilación. Adaptado de Llorca et al., 2006.

\subsection{2.- IMPORTANCIA FISIOLÓGICA Y FISIOPATOLÓGICA}

Las mutaciones en el gen de endoglina suelen conducir a una reducción de los niveles de la proteína y son las responsables de una enfermedad conocida como Telangiectasia Hemorrágica Hereditaria tipo 1 (HHT-1 de Hereditary Haemorraghic Telangiectasia) (McAllister et al., 1994). La HHT-1 es una displasia vascular autosómica dominante asociada con frecuentes epistaxias, sangrados gastrointestinales, 
telangiectasias y malformaciones arteriovenosas en cerebro, pulmón e hígado (Guttmacher et al., 1995; Shovlin, 1997). A nivel microscópico, las lesiones vasculares de la HHT-1 se caracterizan por la dilatación de las vénulas postcapilares. Las vénulas dilatadas se conectan con las arteriolas engrosadas a través de los capilares, los cuales terminan desapareciendo, creando conexiones directas entre las arteriolas y las vénulas. A todos estos cambios hay que añadir un engrosamiento de la pared de los vasos con infiltración de células mononucleares y proliferación de las células del músculo liso vascular (Braverman et al., 1990). Hasta el momento no se conoce la función específica de endoglina en la HHT-1 pero se piensa que está relacionada con el mecanismo de señalización de TGF- $\beta$ puesto que mutaciones en el gen que codifica ALK-1, un receptor señalizante de TGF- $\beta$ altamente expresado en células endoteliales, producen una enfermedad conocida como Telangiectasia Hemorrágica Hereditaria tipo 2 (HHT-2) con alteraciones similares en los vasos (Johnson et al., 1996). Los ratones heterozigotos en el gen de la endoglina (Eng+/-) pueden desarrollar los signos clínicos de la HHT, confirmando este modelo de haploinsuficiencia para la enfermedad (Bourdeau et al., 1999; Bourdeau et al., 2001). Sin embargo, los ratones deficientes en endoglina (Eng-/-) mueren entre los días 10 y 11 de gestación por deficiencias en el desarrollo de los vasos y de las válvulas cardíacas, lo que hace patente el papel de endoglina en los procesos angiogénicos (Arthur et al., 2000; Bourdeau et al., 1999; Li et al., 1999). También se ha encontrado un incremento en la expresión de endoglina en tejidos en los que se está produciendo angiogénesis (Krupinski et al., 1994; Kumar et al., 1999; Rulo et al., 1995; Seon et al., 1997; Wang et al., 1994), probablemente estimulada después de un mecanismo de hipoxia (Sánchez-Elsner et al., 2002) puesto que los ratones deficientes en endoglina tienen disminuida la angiogénisis después de una isquemia (Jerkic et al., 2006). La endoglina se ha relacionado con la angiogénesis tumoral, al verse muy aumentada su expresión en la vasculatura de los tumores sólidos (Burrows et al., 1995; Thorpe y Burrows, 1995; Wang et al., 1993). Los límites de un tumor generalmente presentan altos niveles de neovascularización, sugiriendo una relación potencial de la expresión de endoglina con la proliferación. Además, los ratones deficientes en endoglina presentan una disminución de la angiogénesis tumoral (Düwel et al., 2007). La relación de endoglina con los tumores no se debe únicamente a los procesos de angiogénesis: se ha comprobado que ciertos tipos de células tumorales expresan endoglina; éste es el caso de melanomas (Altomonte et al., 1996), coriocarcinomas (Letamendía et al., 1998b) y tumores de origen hematopoyético, en concreto de linajes 
monocíticos (Haruta y Seon, 1986; Lastres et al., 1996) y de linfocitos B (Zhang et al., 1996). La pérdida del efecto antiproliferativo de TGF- $\beta$ es un punto clave en el desarrollo de muchos procesos tumorales (Serra y Moses, 1996), y estudios realizados en células mieloides tumorales han relacionado la sobreexpresión de endoglina en estas células con la pérdida de dicho efecto. (Calabro et al., 2003).

Adicionalmente, también se ha demostrado la presencia de endoglina en riñones sanos (Quackenbush et al., 1986). En determinadas patologías fibróticas se ha observado un incremento en su expresión: así, los niveles de endoglina aumentan en pacientes con daño renal crónico (Roy-Chaudhury et al. 1997), en ratas con esclerosis glomerular e hipertensión inducida experimentalmente (Rodríguez-Peña et al., 2001 y en ratones sometidos a una obstrucción ureteral unilateral (Rodríguez-Peña et al., 2002). El significado biológico del incremento de la expresión de endoglina en el glomérulo e intersticio de los riñones dañados está por determinar, pero puesto que endoglina es componente del sistema de receptores de TGF- $\beta 1$, y éste estimula la acumulación de matriz extracelular, se puede pensar que la expresión de endoglina por parte de las células mesangiales del glomérulo (Rodríguez-Barbero et al. 2001) puede modular de alguna manera la producción de matriz celular y, en condiciones patológicas, la fibrosis derivada de su exceso.

\subsection{3.- ENDOGLINA SOLUBLE}

Una tercera forma identificada de endoglina es la endoglina soluble (sEng). Esta proteína no deriva de un procesamiento alternativo del gen de endoglina (Venkatesha et al., 2006), por lo que se ha sugerido que son distintos alelos mutados en el gen de endoglina los que pueden producir la molécula soluble (Raab et al., 1999). La endoglina soluble se ha identificado tanto en el suero de individuos sanos como en el de pacientes con diversas enfermedades, entre ellas cáncer (Wang et al., 1994). La comparación de los niveles de endoglina en plasma de individuos sanos y pacientes con cáncer de mama sugiere que altos niveles de la forma soluble pueden representar un marcador de actividad angiogénica, capaz de identificar a los pacientes susceptibles de desarrollar una metástasis (Li et al., 2000a). Recientemente, sEng se ha implicado en la patogénesis de la preeclampsia (Levine et al., 2006; López-Novoa, 2007), una enfermedad que puede desarrollarse durante el embarazo y que ocasiona hipertensión, proteinuria, parto prematuro, hemolisis, anormalidades en el hígado, trombocitopenia, eclampsia y, si no 
es tratada a tiempo, puede ocasionar la muerte. Se ha sugerido que la endoglina soluble ejerce sus efectos antiangiogénicos y pro-hipertensivos en la preeclampsia a través de la unión a moléculas circulantes tales como TGF- $\beta 1$, previniendo la unión de estas moléculas a la endoglina que se encuentra anclada a la membrana (López-Novoa, 2007; Luft, 2006). También se han encontrado niveles elevados de endoglina soluble en pacientes con aterosclerosis (Blann et al., 1996; Li et al., 2000b), y se ha descrito que cambios en los niveles circulantes de sEng pueden predecir la mortalidad tras un infarto de miocardio (Cruz-González et al., 2008).

En definitiva, la endoglina se encuentra presente en un gran número de situaciones fisiológicas y patológicas, si bien en la mayoría de los casos la naturaleza del papel concreto que desempeña queda por determinar. 


$-55-$

2.- OBJETO DEL PRESENTE TRABAJO 
El virus de la enfermedad de Newcastle es un atractivo objeto de estudio desde distintas perspectivas. Su importancia económica como patógeno animal, su similitud con importantes virus humanos o su potencial como herramienta biológica en vacunación y diferentes terapias terapia le convierten en un modelo interesante de estudio de los mecanismos moleculares del ciclo de vida de virus respiratorios con membrana externa y otros virus similares. El desarrollo de las técnicas de genética inversa permite ahondar en estas investigaciones, pero también posibilita que se abran nuevas vías para la utilización del virus como herramienta de estudio o en terapias antivíricas o anticancerígenas.

Una de las posibilidades que permiten las nuevas técnicas es la inclusión de nuevas unidades transcripcionales en el genoma del virus. Los trabajos realizados hasta la fecha con rNDV que expresan proteínas heterólogas se han centrado en el estudio de la biología de los propios virus alterados o en su desarrollo como vectores de vacunación o terapia antitumoral. No obstante, en este trabajo planteamos la utilización del mismo modelo como sistema de expresión de glicoproteínas no víricas vinculadas a otros campos de investigación. Hemos seleccionado una proteína humana, la Lendoglina, relacionada con muchos y muy variados procesos fisiológicos y patológicos. Buscamos generar virus recombinantes que expresararan esta proteína en sistemas celulares, de una manera eficiente y funcional, con lo que pudieran convertirse en herramientas para el estudio de la actividad de la endoglina, o bien facilitar su purificación para posteriores análisis. Bajo estas premisas nos planteamos los siguientes objetivos en la primera parte de esta Tesis Doctoral:

1. Clonar las fases de lectura abiertas de la L-endoglina humana y de una quimera L-endoglina/proteína F del NDV en el cDNA antigenómico completo del NDV de las cepas Hitchner B1 y Hitchner B1/F3aa.

2. Rescatar NDV recombinantes a partir de las citadas construcciones.

3. Determinar la expresión de las proteínas recombinantes en sistemas de cultivo celular

4. Determinar la incorporación de las proteínas recombinantes en la envoltura de los viriones.

5. Determinar la funcionalidad de la endoglina expresada por los rNDV. 
Las técnicas de manipulación genética del NDV también permiten explorar aspectos básicos de su biología, como los mecanismos moleculares de la interacción virus-célula. La fusión entre las membranas vírica y celular en los virus con envoltura es una etapa clave en el desarrollo del ciclo infectivo. La herramienta de la que dispone el NDV para efectuar la fusión, la proteína F, y su mecanismo de acción son muy similares a los de patógenos humanos de gran importancia como el HIV, el RSV, los virus de gripe, el sarampión o las paperas. El conocimiento detallado del proceso de fusión inducido por la proteína F del NDV puede conducir a la generación de estrategias terapeúticas contra ellos, para bloquear etapas tempranas de la interacción virus célula, así como permitir el desarrollo de vehículos de entrada de diferentes moléculas (genes y medicamentos) al interior de la célula. Más aún, la proteína F es el principal factor de virulencia del NDV: con su modificación dirigida puede modularse esa virulencia para potenciar los diversos usos de los vectores rNDV, como por ejemplo en terapias antitumorales. Por todo esto, planteamos como un segundo bloque de objetivos los expuestos a continuación:

6. Clonar las fases de lectura abiertas de las proteínas F y HN del NDV en vectores adecuados para su expresión en cultivos celulares.

7. Mutar residuos en regiones claves del ectodominio de la proteína F.

8. Determinar el efecto de las distintas mutaciones en la fusión de membranas promovida por la proteína $\mathrm{F}$ y analizar los efectos de distintos factores sobre la capacidad fusogénica de los mutantes (temperatura, presencia de la proteína de unión homotípica, niveles de expresión).

9. Combinar los resultados obtenidos con los datos cristalográficos conocidos, e integrarlos en el modelo actualmente propuesto para el mecanismo de fusión de membranas de los paramixovirus. 




\section{1.- MATERIAL Y APARATOS}

$>\quad$ Agitador orbital (ThermoForma).

$>$ Agitadores magnéticos (Agimatic-S. SELECTA).

$>$ Aparatos de electroforesis horizontal (Owl).

> Aparatos de electroforesis vertical en placa Mini Protean (BioRad).

$>$ Aparato de transferencia de proteínas Mini Trans-Blot (BioRad).

$>$ Autoclave (Selecta).

$>$ Balanzas eléctricas analítica y granatoria (Sartorius y Cobos).

$>$ Baños termorregulables.

$>\quad$ Cámara de incubación (Heraeus).

$>\quad$ Cámara frigorífica a $4^{\circ} \mathrm{C}$.

$>$ Cámara Polaroid Electrophoresis Systems FB-PDC-34

$>$ Campana de extracción.

$>$ Campanas de flujo laminar LABCONCO Purifier class II Biosafety Cabinet, de Delta Series.

$>$ Casette de revelado (Amersham Pharmacia Biotech).

> Centrífugas Kubota KR-1500, Heraeus Sepatech Omnifuge 2.0 RS, Beckman J2-21M, Beckman Coulter Allegra 21R Heraeus Biofuge, Selecta.

$>$ Citómetro de flujo FACScalibur (Becton Dickinson)

$>$ Congeladores de $-20^{\circ} \mathrm{C} \mathrm{y}-80^{\circ} \mathrm{C}$ (Revco).

> Espectofotómetros GeneQuant pro RNA/DNA Calculator (Amersham Pharmacia Biotech), LKB Novaspek II.

$>\quad$ Estufa Heraeus.

$>\quad$ Filtros estériles de $0,22 \mu \mathrm{m}$ (Millipore).

$>$ Incubadores para cultivos celulares (Heraeus).

$>$ Incubadora de huevos $\Sigma 210-\Sigma 252$ (Maino)

$>\quad$ Lector de placas "Fluoroskan Ascent FL" (Termoelectron Co).

$>$ Membranas de PVDF (difluoruro de polivinilino) (Pall Gelman).

$>$ Microscopio invertido de fluorescencia Olympus 1 X51.

$>\quad$ pH-metro digital Mini pH 2001 (Crison).

> Películas “Super RX X-Ray Film” (Fujifilm). 
Placas para cultivo celular 35 × $10 \mathrm{~mm}, 100$ x $20 \mathrm{~mm}$; y de 6, 12 y 24 pocillos (Falcon).

> Placas para hemaglutinación 96 pocillos fondo cónico o plano (Sigma).

$>\quad$ Rotores de centrífuga SW-28, JA-10, JLA-16.250, 70.1 Ti con tubos y complementos adecuados (Beckman Coulter).

$>$ Secuenciador automático ABI PRISM (Modelo 377).

$>\quad$ Sistema de purificación de agua ultrapura MiliQ (Millipore).

$>$ Termociclador PTC-100, de MJ Research, Inc.

> Transiluminadores de luz U.V. FBT188, de Fisher Scientific, y TFX-35M, de Vilber Lourmat.

- Ultracentrífugas refrigeradas Beckman Optima XL-100k, Beckman L8M. (Beckman Coulter)

> Unidades de corriente Miniphore Power Suply (Techne).

$>$ Ordenadores PC compatibles.

$>$ Cámaras digitales Kodak DC120 y Kodak GL-100.

$>$ Cámara digital DP170, de Olympus.

$>\quad$ Material de uso corriente en el laboratorio.

\section{2.- MATERIAL INFORMÁTICO.}

La redacción del presente trabajo se realizó con el procesador de texto "Microsoft Word". El procesado de los datos y su conversión en gráficos se hizo con "Microsoft Excel". Las ilustraciones y esquemas se efectuaron con el programa "Microsoft Power Point". Las fotografías de geles fueron adquiridas y procesadas con el programa "Kodak Digital Science" v. 3.0. Las imágenes del microscopio de fluorescencia se procesaron con el programa “Adobe Photoshop”. La cuantificación de las bandas en geles se hizo por medio del programa "Scion Image".

Para el análisis de las secuencias de DNA se empleó el programa "Chromas 2.3", disponible en http://www.technelysium.com.au/chromas.html. Los plásmidos que aparecen en este apartado se diseñaron con el programa "BioEdit" v. 7.0.4 (http://www.mbio.ncsu.edu/BioEdit/bioedit.html). Para el procesamiento de las 
secuenciaciones se utilizó el programa "CodonCode Aligner", disponible en la dirección http://www.codoncode.com. El análisis de sitios de reconocimiento para endonucleasas de restricción se llevó a cabo con el programa "Webcutter 2.0", disponible en http://rna.lundberg.gu.se/cutter2.

El análisis de los datos de citometría de flujo se realizó con el programa “WinMDI 2.8", disponible en http://facs.scripps.edu/software.html.

La búsqueda de secuencias de DNA y proteínas se llevó a cabo en la base de datos Gen Bank (http://www.ncbi.nlm.nih.gov/Genbank/index.html). La búsqueda de referencias se llevó a cabo mediante la página web Medline (National Library of Medicine, E.E.U.U.) en la dirección de Internet http://www.ncbi.nlm.nih.gov/entrez. El procesado de las mismas se realizaró con el programa “Reference Manager" v. 10.

\section{3.- REACTIVOS.}

Aceite mineral, de Sigma Chemical Co. (St Louis, MO, E.E.U.U.)

Acetoximetil calceína, de Molecular Probes (Eugene, OR, E.E.U.U.), de

Ácido etilendiaminotetraacético (EDTA), de Sigma Chemical Co. (St Louis, MO, E.E.U.U.)

$>\quad$ Ácido desoxicólico, de Sigma Chemical Co. (St Louis, MO, E.E.U.U.)

$>\quad$ Acrilamida, de Bio Rad (Richmond, CA, E.E.U.U..)

$>\quad$ Agarosa ultraPure, de GibcoBRL, Life Technologies (R.U.)

$>$ 5-Amino-2,3-dihidro-1,4-ftalatozinediona (luminol), de Sigma Chemical Co (St. Louis, MO, E.E.U.U.)

Ampicilina, de Boehringer-Mannheim (Alemania)

Aprotinina, de Sigma Chemical Co (St. Louis, MO, E.E.U.U.)

$>\quad$ Bactotriptona de Oxoid (R.U..)

> 5-Bromo-4-cloro-3-indolil- $\beta$-D-galactopiranósido (X-Gal), de Promega (Madison, WI, E.E.U.U.)

$>$ Bromuro de etidio, de Boehringer-Mannheim (Alemania)

$>$ Cloruro de octadecil rodamina (R18), de Molecular Probes (Eugene, OR, E.E.U.U.)

$>\quad$ Cloruro de Cesio, de Sigma Chemical Co (St. Louis, MO, E.E.U.U.)

$>$ Desoxinucleótidos trifosfato (dNTPs) de Invitrogen (Carlsbad, CA, E.E.U.U.) 
Dodecil sulfato sódico (SDS) de Sigma Chemical Co (St. Louis, MO, E.E.U.U.)

$>$ Endonucleasas de restricción de New England Biolabs (R.U.) y Promega (Madison, WI, E.E.U.U.)

Extracto de levadura, de Oxoid (R.U.)

"FACS lysing solution", de Becton Dickinson (San José, CA, E.E.U.U.)

Fluoruro de metil-fenil-sulfonilo (PMSF), de Sigma Chemical Co (St. Louis, MO, E.E.U.U.)

$>$ Fosfatasa alcalina intestinal (CIP), de New England Biolabs (R.U.)

$>\quad$ L-Glutamina 100X, de GibcoBRL, Life Technologies (R.U.)

$>\quad$ Hoechst 33258 pentahidrato, de Molecular Probes (Eugene, OR, E.E.U.U.)

> 4-Iodofenol, de Aldrich Chemical Company, Inc. (Milwaukee, WI, E.E.U.U.)

Inhibidor de acetil-tripsina, de Sigma Chemical Co (St. Louis, MO, E.E.U.U.)

$>$ Isopropil- $\beta$-D-tiogalactopiranósido (IPTG), de Promega (Madison, WI, E.E.U.U.)

Leupeptina, de Sigma Chemical Co (St. Louis, MO, E.E.U.U.)

$>\quad$ Lipofectamina 2000, de Invitrogen (Carlsbad, CA, E.E.U.U.)

$>$ Medio mínimo esencial de Eagle (EMEM), de Cambrex (East Rutherford, NJ, E.E.U.U.)

$>$ Medio de Eagle, modificado por Dulbecco (DMEM), de GibcoBRL, Life Technologies (R.U..)

$>\quad \beta$-Mercaptoetanol, de Sigma Chemical Co (St. Louis, MO, E.E.U.U.)

$>$ Monolaurato de polioxietilén-(20)-sorbitán (Tween-20), de Sigma Chemical Co (St. Louis, MO, E.E.U.U.)

$>\quad N$-Acetil Tripsina (EC 3.4.21.4), de Sigma Chemical Co. (St. Louis, MO, E.E.U.U.)

$>\quad N, N, N^{\prime}, N^{\prime}$,-tetrametil-etilendiamina (TEMED), de Bio Rad (Richmond, CA, E.E.U.U..)

$>\quad N, N^{\prime},-$-metilen-bis-acrilamida, de Bio Rad (Richmond, CA, E.E.U.U.)

$>$ OptiMEM I, de GibcoBRL, Life Technologies (R.U..)

$>\quad$ Paraformaldehído de Sigma Chemical Co (St. Louis, MO, E.E.U.U.) 
Patrones de DNA de peso molecular de 100 bp a $12 \mathrm{~Kb}$ (“1 $1 \mathrm{~Kb}$ Plus DNA Ladder") y de $8,3 \mathrm{~Kb}$ a 48,5 Kb ("High Molecular Weight DNA Markers"), de Invitrogen (Carlsbad, CA, E.E.U.U.)

$>$ Patrones de marcadores de proteínas preteñidas marcadoras de peso molecular para SDS-PAGE "Bench Mark Pre-Stained Protein Ladder", de Invitrogen (Carlsbad, CA, E.E.U.U.)

$>$ Penicilina/Estreptomicina 100X, de GibcoBRL, Life Technologies (R.U.)

$>\quad$ Pepstatina A, de Sigma Chemical Co (St. Louis, MO, E.E.U.U.)

$>\quad$ Peptona triptona, de Difco (Detroit, MI, E.E.U.U.)

> Persulfato amónico (APS), de Sigma Chemical Co (St. Louis, MO, E.E.U.U.)

$>\quad$ "pGEM-T Vector System", de Promega (Madison, WI, E.E.U.U..)

> "QIAGEN Plasmid Maxi Kit", de Qiagen INC. (Chatsworth, CA, E.E.U.U.)

$>\quad$ “QIAprep Spin Plasmid", de Qiagen INC. (Chatsworth, CA, E.E.U.U.)

$>\quad$ "QIAquick Gel Extraction Kit", de Qiagen INC. (Chatsworth, CA, E.E.U.U.)

$>\quad$ "QIAquick PCR Purification Kit", de Qiagen INC. (Chatsworth, CA, E.E.U.U.)

> "Rapid DNA Ligation Kit", de Roche (Alemania)

> "RAseOUT Recombinant Ribonuclease Inhibitor", de Invitrogen (Carlsbad, CA, E.E.U.U.)

> Seroalbúmina bovina (BSA), de Sigma Chemical Co (St. Louis, MO, E.E.U.U.)

$>\quad$ Suero bovino fetal (FBS), de HyClone (Logan, UT, E.E.U.U.)

> “SuperScript III Reverse Transcriptase", de Invitrogen (Carlsbad, CA, E.E.U.U.)

> “TripleMaster PCR System”, de Eppendorf (Alemania)

$>$ Tripsina-EDTA, de GibcoBRL, Life Technologies (R.U.)

$>$ Tris(hidroximetil)aminometano (Tris) de Sigma Chemical Co (St. Louis, MO, E.E.U.U.)

> “TRIzol Reagent", de Invitrogen (Carlsbad, CA, E.E.U.U.) 
El resto de los reactivos utilizados en este trabajo fueron de grado analítico y procedían de Probus o Panreac (España).

\section{4.- MEDIOS DE CULTIVO.}

\subsection{1.- MEDIOS Y SOLUCIONES PARA CULTIVO CELULAR.}

- $\quad$ EMEM-10\%FBS/PS: 50ml EMEM 10X; 50ml FBS (inactivado por calentamiento a $56^{\circ} \mathrm{C}$ durante $30 \mathrm{~min}$ ); $5 \mathrm{ml}$ Penicilina/Estreptomicina 100X; 5ml L-Glutamina 200mM; ajustado a un volumen total de $500 \mathrm{ml}$ con $\mathrm{H}_{2} \mathrm{O}$ ultrapura autoclavada.

- DMEM-10\%FBS sin antibióticos: 450ml DMEM; 50ml FBS inactivado por calentamiento

- DMEM-10\%FBS/PS: 450ml DMEM; 50ml FBS inactivado por calentamiento; Penicilina/Estreptomicina 100X 5ml.

- 10X PBS (Solución amortiguadora de fosfatos): $80 \mathrm{~g} \mathrm{NaCl} ; 2 \mathrm{~g} \mathrm{KCl} ; 11.5 \mathrm{~g}$ $\mathrm{Na}_{2} \mathrm{HPO}_{4} \cdot 7 \mathrm{H}_{2} \mathrm{O} ; 2 \mathrm{~g} \mathrm{KH} \mathrm{KH}_{2} \mathrm{PO}$; ajustado a $1 \mathrm{~L}$ con $\mathrm{H}_{2} \mathrm{O}$ ultrapura, ajustado a pH 7.3 y autoclavado. Para la solución de trabajo (1X PBS), se diluyó 1:10 en $\mathrm{H}_{2} \mathrm{O}$ ultrapura y se autoclavó.

- PBS/BA/PS: 5ml Penicilina/estreptomicina 100X; 3ml seroalbúmina bovina al $35 \%$; ajustado a un volumen total de $500 \mathrm{ml}$ con $1 \mathrm{X}$ PBS.

\subsection{2.- MEDIOS DE CULTIVO PARA EL CRECIMIENTO DE BACTERIAS.}

- $\quad$ SOC ( Super Optimal broth with Catabolite repression): Extracto de levadura 0,5\%; bactotriptona, $2 \%$; $\mathrm{NaCl} 10 \mathrm{mM} ; \mathrm{KCl} 2,5 \mathrm{mM} ; \mathrm{MgCl}_{2} 10 \mathrm{mM}$; $\mathrm{MgSO}_{4}$ 10mM; glucosa 20mM.

- $\quad$ TB (Terrific Broth) : Extracto de levadura 2,4\%; bactotriptona 1,2\%; glicerol $0,4 \% ; \mathrm{KH}_{2} \mathrm{PO}_{4} 0,23 \% ; \mathrm{K}_{2} \mathrm{HPO}_{4} 1,25 \%$.

- $\quad$ LB (Luria-Bertani): Extracto de levadura 0,5\%; bactotriptona 1\%; $\mathrm{NaCl} 1 \%$.

- LB-Agar: Extracto de levadura 0,5\%; bactotriptona 1\%; $\mathrm{NaCl} 1 \%$; agar 1,5 


\section{5.- MATERIAL BIOLÓGICO.}

\subsection{1.- ANTICUERPOS}

La Tabla 3.1 resume las características de los distintos anticuerpos utilizados en la realización de esta tesis.

\subsection{2.- HUEVOS EMBRIONADOS DE POLLO.}

Se emplearon huevos embrionados de pollo libres de patógenos específicos (SPF), suministrados a los 8-10 días (Charles River SPAFAS, Conn. E.E.U.U) y huevos SPF suministrados a los 0 días por la Granja Rodríguez Serrano, Alba de Tormes, Salamanca. Los huevos se mantuvieron en una incubadora a $37,7^{\circ} \mathrm{C}$ y $40 \%$ de humedad hasta el día 7, a partir del cual se incrementó la humedad hasta el 70\%.

\subsection{3.- CULTIVOS CELULARES.}

Durante la realización de este proyecto de tesis se han empleado las siguientes líneas celulares de mamífero:

- Células Vero: células de epitelio renal de mono verde africano. (ATCC Cat. No. CCL-81).

- Células A549: células epiteliales, tejido carcinomatoso pulmonar humano. (ATCC Cat. No. CCL-185).

- Células HeLa: células epiteliales, adenocarcinoma de cuello de útero humano (ATCC Cat. No. CCL-2).

- Células BHK-21: fibroblastos renales de hámster (ATCC Cat. No. CCL-10).

- Células K18: células mesangiales humanas inmortalizadas con el antígeno T de SV40 (Banas et al., 1999), amablemente cedidas por el equipo del Dr. José Miguel López Novoa, Departamento de Fisiología y Farmacología, Universidad de Salamanca. 


\begin{tabular}{|c|c|c|c|}
\hline & \multicolumn{3}{|c|}{ TABLA 3.1 Anticuerpos empleados en el presente trabajo } \\
\hline & Anticuerpo & Procedencia & $\begin{array}{c}\text { Solución de } \\
\text { trabajo/Aplicación }\end{array}$ \\
\hline \multirow{8}{*}{ 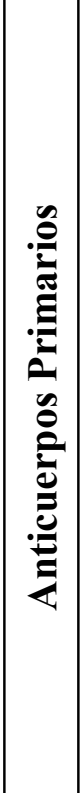 } & mAb anti-F $2 \mathrm{A6}$ & $\begin{array}{l}\text { Dr. Adolfo García Sastre } \\
\text { (MSSM, NY, EE.UU) }\end{array}$ & $10 \mu \mathrm{g} / \mathrm{ml}(\mathrm{IF}, \mathrm{CIT})$ \\
\hline & pAb anti-NDV & $\begin{array}{l}\text { Dr. Adolfo García Sastre } \\
\text { (MSSM, NY, EE.UU) }\end{array}$ & $5 \mu \mathrm{g} / \mathrm{ml}(\mathrm{IF}, \mathrm{CIT})$ \\
\hline & $\begin{array}{l}\text { mAb anti-endoglina } \\
\text { humana P3D1 }\end{array}$ & $\begin{array}{l}\text { Dr. Carmelo Bernabéu (CIB- } \\
\text { CSIC, Madrid) }\end{array}$ & $\begin{array}{l}1: 2 \text { (sobrenadante de } \\
\text { hibridoma) (IF) }\end{array}$ \\
\hline & $\begin{array}{l}\text { mAb anti-endoglina } \\
\text { humana P4A4 }\end{array}$ & $\begin{array}{l}\text { Dr. Carmelo Bernabéu (CIB- } \\
\text { CSIC, Madrid) }\end{array}$ & $\begin{array}{c}\text { 1:5 (sobrenadante de } \\
\text { hibridoma) (WB) }\end{array}$ \\
\hline & $\begin{array}{l}\text { mAb anti-endoglina } \\
\text { humana TEA 1/58-1 }\end{array}$ & $\begin{array}{l}\text { Dr. Carmelo Bernabéu (CIB- } \\
\text { CSIC, Madrid) }\end{array}$ & $\begin{array}{l}\text { 1:10 (sobrenadante de } \\
\text { hibridoma) (WB) }\end{array}$ \\
\hline & mAb anti-tubulina & Calbiochem (CA, EE.UU) & $1: 5000$ (WB) \\
\hline & pAb anti-colágeno I & Chemicon (CA, EE.UU) & $1: 20000(\mathrm{WB})$ \\
\hline & pAb anti-fibronectina & Chemicon (CA, EE.UU) & $1: 40000(\mathrm{WB})$ \\
\hline \multirow{5}{*}{ 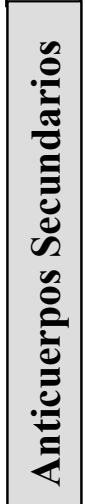 } & $\begin{array}{l}\text { AlexaFluor } 488 \text { cabra anti- } \\
\text { conejo IgG }\end{array}$ & $\begin{array}{l}\text { Molecular Probes (OR, } \\
\text { EE.UU) }\end{array}$ & $1: 400(\mathrm{IF}, \mathrm{CIT})$ \\
\hline & $\begin{array}{l}\text { AlexaFluor } 488 \text { cabra anti- } \\
\text { ratón IgG }\end{array}$ & $\begin{array}{l}\text { Molecular Probes (OR, } \\
\text { EE.UU) }\end{array}$ & $1: 400(\mathrm{IF}, \mathrm{CIT})$ \\
\hline & $\begin{array}{l}\text { AlexaFluor } 568 \text { cabra anti- } \\
\text { ratón IgG }\end{array}$ & $\begin{array}{l}\text { Molecular Probes (OR, } \\
\text { EE.UU) }\end{array}$ & $1: 400(\mathrm{IF})$ \\
\hline & Cabra anti-conejo IgG-HRP & Santa-Cruz (CA, EE.UU) & $1: 20000(\mathrm{WB})$ \\
\hline & Cabra anti-ratón IgG-HRP & Santa-Cruz (CA, EE.UU) & $1: 15000(\mathrm{WB})$ \\
\hline
\end{tabular}

mAb: Anticuerpo monoclonal; pAb: Anticuerpo policlonal; HRP: Peroxidasa de rábano; IF: Inmunofluorescencia; CIT: Citometría de flujo; WB: Western-blot

Todas las citadas líneas celulares se mantuvieron en DMEM-10\%FBS/PS, a $37^{\circ} \mathrm{C}$ en una atmósfera húmeda con $5 \%$ de $\mathrm{CO}_{2}$.

Además, en el presente trabajo se han utilizado cultivos primarios de células mesangiales humanas (CMH) y de células mesangiales de rata Wistar-Kyoto (WKY), ambos obtenidos y cedidos por el equipo del Dr. José Miguel López Novoa. Estas células se mantuvieron en RPMI 1640 (Cambrex BioScience, ME, E.E.U.U.) suplementado con insulina $5 \mu \mathrm{g} / \mathrm{ml}$, transferrina $5 \mu \mathrm{g} / \mathrm{ml}$, selenio $5 \mathrm{ng} / \mathrm{ml}$, L-glutamina $1 \mathrm{mM}$, anfotericina B $2,5 \mu \mathrm{g} / \mathrm{ml}$, penicilina $50 \mathrm{U} / \mathrm{ml}$ y estreptomicina $50 \mu \mathrm{g} / \mathrm{ml}$. También 
se trabajó con cultivos primarios de fibroblastos de embrión de pollo, tal y como se detalla a continuación.

\subsubsection{1- Fibroblastos de embrión de pollo (CEF). Obtención.}

Para obtener el cultivo primario de CEF empleado en este trabajo se partió de huevos de pollo libres de patógenos de 9 a 11 días. Todo el proceso de su obtención se llevó a cabo en condiciones de esterilidad. Cuidadosamente, se rompió la cáscara del huevo y se extrajo el embrión, depositándolo sobre una placa Petri de $100 \mathrm{~mm}$. Se le retiraron con unas pinzas las alas, patas y órganos internos. El tejido resultante se troceó con unas tijeras en pequeñas porciones y se lavó 2 veces con $20 \mathrm{ml}$ de PBS. Tras los lavados se añadieron $20 \mathrm{ml}$ de PBS con acetiltripsina (0,25\%), y el conjunto se pasó a un matraz tripsinizador con agitación magnética, donde se mantuvo $20 \mathrm{~min}$ a temperatura ambiente. Pasado este tiempo se bloqueó la acción de la tripsina con $1 \mathrm{ml}$ de FBS, y se pasó el contenido del tripsinizador a un tubo Falcon de $50 \mathrm{ml}$. Se dejó reposar $5 \mathrm{~min}$ y después se pasó el sobrenadante a un nuevo tubo de $50 \mathrm{ml}$, que se centrífugo $5 \mathrm{~min}$ a $1000 \mathrm{rpm}(200 \mathrm{~g})$. El sedimento se resuspendió en $20 \mathrm{ml}$ de PBS y se pasó por un embudo con malla filtradora estéril (la malla se cambió cada $5 \mathrm{ml}$ ), recogiendo todo el volumen en otro tubo de $50 \mathrm{ml}$, que se centrífugo $5 \mathrm{~min}$ a $1000 \mathrm{rpm}$. Finalmente, el sedimento se resuspendió en $20 \mathrm{ml}$ de medio EMEM-10\%FBS/PS, que se repartieron entre dos placas de $100 \mathrm{~mm}$, a partir de las cuales se mantuvo el cultivo primario en medio EMEM-10\%FBS/PS a $37^{\circ} \mathrm{C}$ en una atmósfera húmeda con $5 \%$ de $\mathrm{CO}_{2}$.

\subsection{4.- VIRUS.}

Durante el presente trabajo se utilizaron los siguientes virus, que fueron amablemente cedidos por el doctor Adolfo García Sastre del Departamento de Microbiología de la Mount Sinai School of Medicine, (Nueva York, E.E.U.U.).

- $\quad$ MVA-T7: virus vaccinia Ankara modificado con el gen de la RNA polimerasa del fago T7 (Wyatt et al., 1995) Originalmente cedido por el doctor Bernard Moss (NIH, Bethesda, E.E.U.U.).

- rNDV-F3aa-mRFP: virus de la enfermedad de Newcastle recombinante que expresa la proteína monomérica roja fluorescente (Campbell et al., 2002). Clonado y rescatado por los doctores Luis Martínez Sobrido y 
Jerome Cros, del Departamento de Microbiología de la Mount Sinai School of Medicine, (Nueva York, E.E.U.U.), a partir del pNDV-F3aa (Mibayashi et al., 2007; apartado 1.4.2).

\subsection{5.- ERITROCITOS.}

Los eritrocitos de pavo empleados en los ensayos de hemaglutinación para la detección de NDV se obtuvieron de Truslow Farms (Chesterton, MD, E.E.U.U.).

Los eritrocitos humanos empleados en los ensayos de transferencia de sonda se deben a la generosidad de donantes anónimos del Centro de Hemoterapia y Hemodonación de Castilla y León, y fueron recogidos y suministrados por el personal de dicho Centro en el Hospital Virgen de la Vega de Salamanca.

\subsection{6.- CEPAS BACTERIANAS.}

Escherichia coli DH5a, con competencia químicamente adquirida, de Invitrogen (Carlsbad, CA, E.E.U.U.). Esta cepa contiene mutaciones que impiden la recombinación, asegurando la estabilidad de los insertos y mejorando la calidad del DNA plasmídico obtenido de ellas. También permite el sistema de selección por color de las colonias por acción de la $\beta$-galactosidasa.

Epicurian coli XL1-Blue, suministrada por la casa comercial Stratagene con el kit "QuickChange Site-Directed Mutagenesis".

Los cultivos bacterianos se mantuvieron a $30^{\circ} \mathrm{C}$. En el caso de los cultivos en medio líquido, éstos se inocularon con una colonia individual o una réplica de la misma y se mantuvieron en agitación a $250 \mathrm{rpm}$ procurando no sobrepasar con el medio un tercio del volumen del recipiente.

\subsection{7.- PLÁSMIDOS.}

\subsubsection{1.- $p T M 1-N P, p T M 1-P$ y $p T M 1-L$.}

El vector pTM1 es un plásmido derivado del pUC con el promotor T7Ф10, la región no traducida (UTR) del virus de la encefalomiocarditis (EMCV), un sitio de 
clonación múltiple (MCS), el terminador transcripcional T7, la secuencia del gen de la timidina quinasa del virus vaccinia y un origen de replicación de DNA de cadena sencilla f1.

El vector pTM1 está diseñado para expresar genes bajo control del promotor T7/EMCV UTR, lo que significa que la expresión génica está controlada por la RNA polimerasa del fago T7, como la expresada por el virus MVA-T7 antes citado. Aunque las cantidades de RNA producido por esa polimerasa son extraordinariamente altas (aproximadamente un 30\% del total del RNA en el citoplasma), el análisis de los transcritos revela que sólo un 5\% se modifica con el cap o caperuza en 5', y dado que ello es necesario para una traducción eficiente en células eucariotas sólo se consiguen niveles moderados de síntesis proteica. Por esta razón se creó el pTM1, en el que se incluyó, justo detrás del promotor T7, la región no traducida (UTR) del virus de la encefalomiocarditis (EMCV). Este virus pertenece a la familia Picornaviridae, en la que los transcritos se generan sin cap pero disponen de esta región no codificante para facilitar la unión al ribosoma. De esta manera se consigue aumentar la expresión del gen deseado entre 5 y 10 veces.

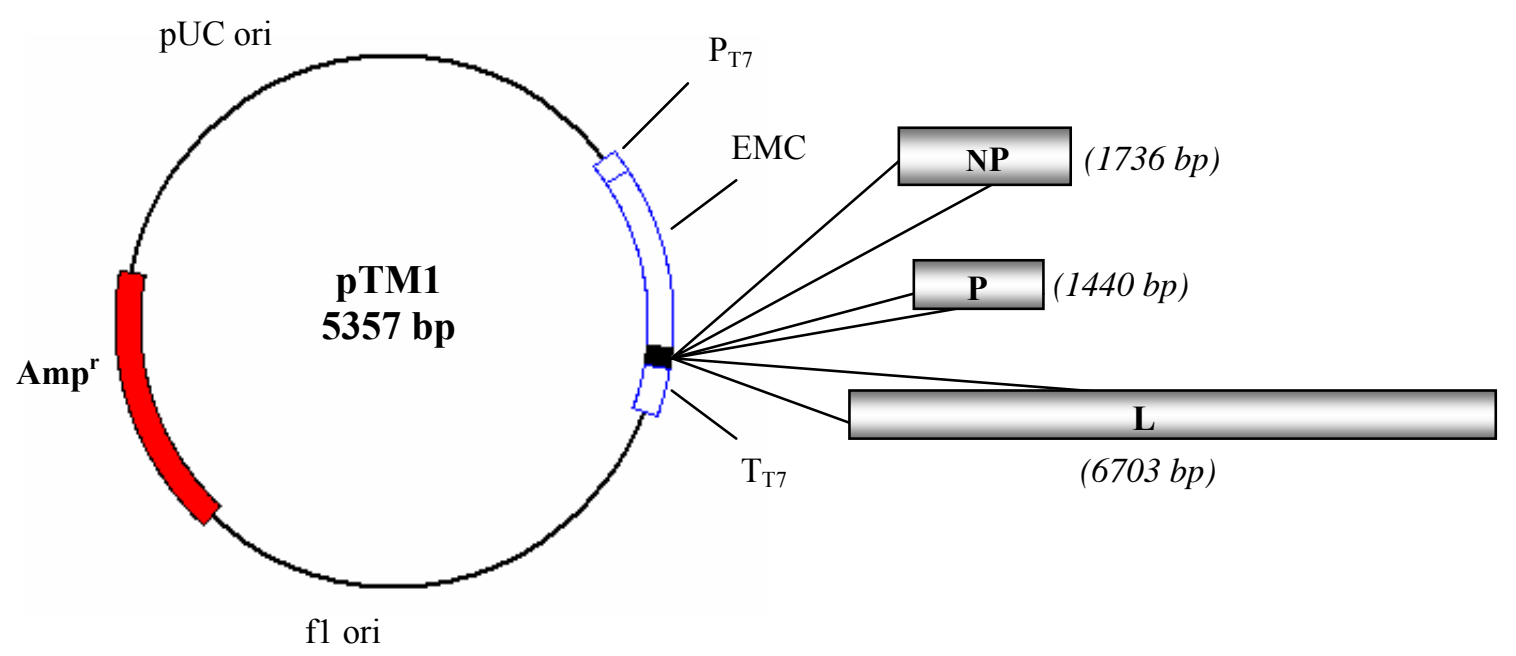

Figura3.1. Mapa del vector pTM1, mostrando dónde se encuentran clonados los genes NP, P o L, así como el tamaño de los mismos

El cDNA de los genes NP, P y L de la cepa Hitchner B1 del NDV, obtenido por RT-PCR a partir del RNA vírico, fue clonado en pTM1 por el doctor Hongyong Zheng, del Departamento de Microbiología de la Mount Sinai School of Medicine, (Nueva 
York, E.E.U.U.) para construir los vectores pTM1-NP, pTM1-P y pTM1-L (Nakaya et al., 2001). Un mapa de los mismos aparece en la Figura3.1. Los genes NP y P se clonaron entre los sitios de restricción PstI y NcoI; el gen L, de mucho mayor tamaño y que precisó tres pasos en su clonación, entre NcoI y SpeI.

\subsubsection{2.- $p G E M-T$.}

pGEM-T es un vector comercial que permite clonar directamente productos de PCR, en los que generalmente las polimerasas añaden un nucleótido A adicional en los extremos 3' de cada hebra. El vector se encuentra linealizado y en ambos extremos hay nucleótidos $\mathrm{T}$ desapareados. Esto proporciona una alta eficiencia de ligación con el producto de PCR, evitando los fenómenos de recircularización. Además la región de clonación está incluida dentro de la secuencia que codifica la $\beta$-galactosidasa (LaCZ), de modo que, en presencia del inductor IPTG y del sustrato X-Gal, es posible la selección de clones recombinantes basándose en el color de las colonias de las placas (las colonias azules, por acción de la $\beta$-galactosidasa, son negativas y las blancas, positivas). La Figura3.2 muestra el mapa suministrado por la casa comercial del vector pGEM-T.

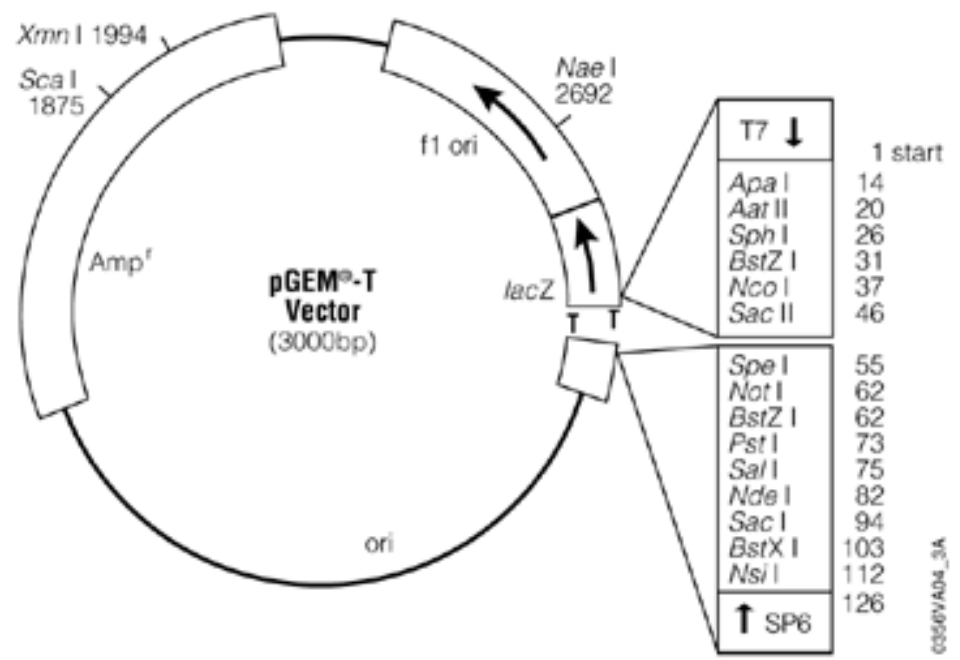

Figura3.2. Mapa del vector pGEM-T, tomado de la página web de la casa comercial Promega: http://www.promega.com. 


\subsubsection{3.- $p N D V-B 1$ y $p N D V-F 3 a a$.}

El plásmido pNDV-B1 (Nakaya et al., 2001), con el cDNA completo, full length, (15186 nucleótidos) del antigenoma del NDV de la cepa Hitchner B1, fue construido a partir de fragmentos de PCR ensamblados conjuntamente en el plásmido pSL1180 (Amersham Pharmacia Biotech). El cDNA del virus se puso bajo control del promotor y el terminador de la polimerasa de T7, y antes de este último, en el extremo $3^{\prime}$, se añadió la secuencia de la ribozima del virus de la hepatitis delta (HDV), que al procesar el transcrito primario permitiría que su extremo $3^{\prime}$ tuviera exactamente la longitud deseada y fuera igual que el extremo del antigenoma vírico. Durante el proceso de clonación, se añadieron al genoma del virus dos sitios únicos de restricción como marcadores genéticos y lugares para la introducción de genes foráneos: en la posición 1755, entre las ORF de los genes NP y P, se introdujo un sitio Sac II; en 3163, entre P y M, un sitio Xba I. En este último han sido clonados en sucesivos trabajos (apartado 1.4.2, Tabla 1.4) los genes codificantes de distintas proteínas: la cloranfenicol acetil transferasa (CAT), la hemaglutinina (HA) del virus de la gripe A/WSN/33 (Nakaya et al., 2001) y de la gripe aviar A/chicken/NY/13142-5/94 (Swayne et al., 2003), la proteína fluorescente verde (GFP) (Park et al., 2003a), la proteína NS1 del virus de la gripe (Park et al., 2003b), las proteínas gag de los virus de la inmunodeficiencia de simios (SIV) (Nakaya et al., 2004) y humana (VIH) (Carnero et al., 2008), la luciferasa de luciérnaga y distintas citocinas inmunoestimulantes (Vigil et al., 2007). A partir de estas construcciones se rescataron con éxito NDV recombinantes y se analizó su utilización como vectores de vacunación en modelos animales, herramientas para el estudio del NDV y agentes antitumorales. La secuencia del genoma vírico clonada en pNDV-B1 fue remitida a GenBank, donde se encuentra con el número de acceso AF375823.

El plásmido pNDV-F3aa es una modificación del anterior realizada por el mismo equipo (Park et al., 2006). Contiene tres sustituciones aminoacídicas en la proteína F, tal y como se muestra en la Figura 3.5, que la hacen accesible a proteasas celulares de la familia de las furinas. Estos cambios modifican la virulencia de los virus rescatados a partir del pNDV-F3aa, de forma que una cepa originalmente lentogénica pasa a ser mesogénica. El pNDV-F3aa fue originalmente diseñado para inducir una mejor inmunidad en pollos vacunados con rNDV expresando la HA de gripe aviar (Park 
et al., 2006). Trabajos posteriores(apartado 1.4.2, Tabla 1.4) demostraron que el rNDVF3aa también incrementaba la capacidad oncolítica del NDV-B1 (Vigil et al., 2007), capacidad que se ha visto aún más reforzada en rNDV-F3aa recombinantes que expresan citocinas inmunoestimulantes (Vigil et al., 2006) y antígenos asociados a tumores (Vigil et al., 2008). Además, el pNDV-F3aa facilita el proceso de rescate de virus recombinantes al poder realizarse en medio sin tripsina ni líquido alantoideo añadidos exógenamente, que de otra manera serían necesarios para la activación proteolítica de F.

$\sim 15,5 \mathrm{~Kb}$

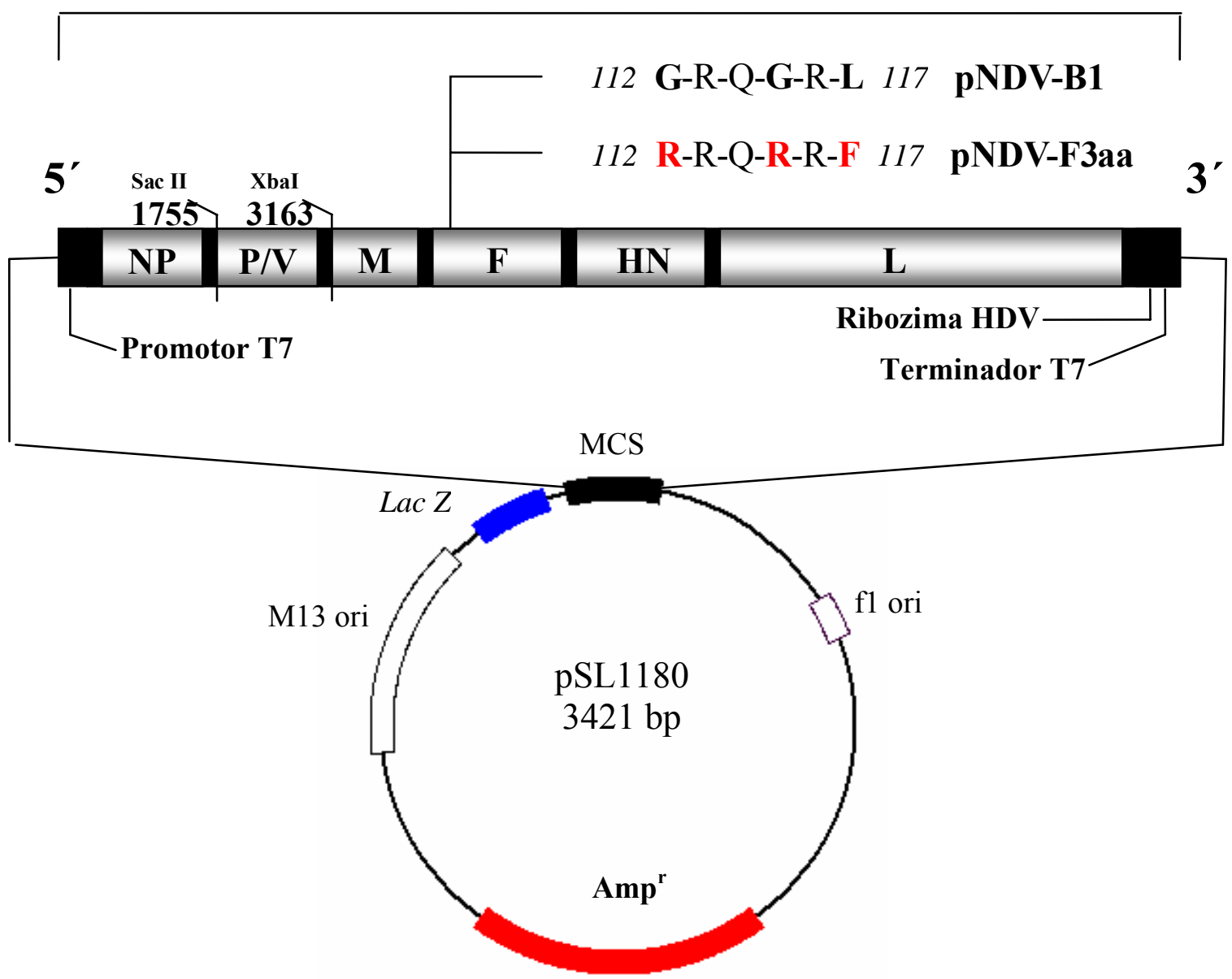

Figura3.3. Representación esquemática de pNDV-B1 y pNDV-F3aa, indicando las diferencias que hay entre ambos, los reguladores clonados aguas arriba y abajo del genoma y los marcadores genéticos introducidos artificialmente 


\subsubsection{4.- pGEM- NDV-F|TMCyt.}

pGEM- NDV-F\TMCyt es un vector lanzadera que permite clonar de manera muy sencilla el dominio extracelular de una proteína de membrana tipo I conjuntamente con los dominios transmembrana y citoplasmático de la proteína de fusión del NDV (F), originando quimeras de cDNA que pueden a su vez clonarse en un vector con el cDNA full length del virus. Fue originalmente diseñado por el doctor Man-Seong Park, del Departamento de Microbiología de la Mount Sinai School of Medicine, (Nueva York, E.E.U.U.), para clonar el dominio extracelular de la proteína hemaglutinina (HA) del virus de la gripe (Park et al, 2006).

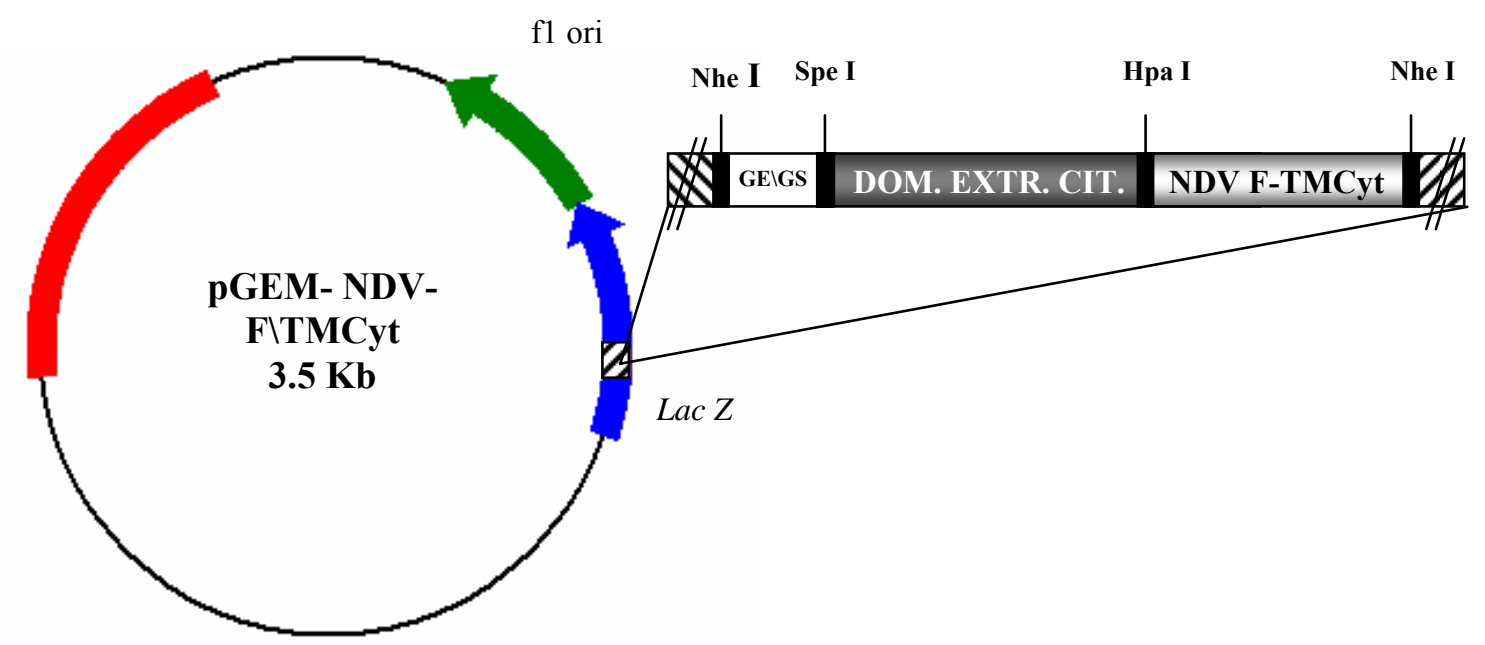

Figura3.4. Estructura del vector lanzadera pGEM-NDV-F\TMCyt.: el inserto deseado se clona entre los sitios Spe I y Hpa I, y posteriormente puede extraerse mediante digestión con Nhe I la construcción completa con las señales de final de gen y comienzo de gen (GE\GS), el dominio extracelular de la proteína deseada y los dominios transmembrana y citoplásmico de NDV F.

El vector lanzadera es una construcción realizada sobre el vector comercial pGEM-T. El inserto que contiene la fase de lectura del dominio extracelular de la proteína de membrana se clona direccionalmente entre dos sitios de restricción SpeI y HpaI. Aguas arriba del primero se encuentra la región reguladora que permitirá la correcta expresión de la quimera dentro del genoma vírico, GE, IS y GS; y aguas abajo del segundo se encuentran las secuencias de los dominios transmembrana y citoplasmático de la proteína $\mathrm{F}$. Una vez clonado el inserto en el vector lanzadera, todo el fragmento que a su vez será clonado en el cDNA full length se halla flanqueado por 
sitios de restricción NheI, con lo que resulta fácil de extraer. El lugar indicado para la clonación de un gen foráneo en el cDNA del $\mathrm{NDV}$, entre las proteínas $\mathrm{P}$ y $\mathrm{M}$, fue diseñado con un sitio de restricción XbaI, compatible con NheI, por lo que puede procederse directamente a la clonación en el mismo.

\subsubsection{5.- pCMV5-EndoL.}

El cDNA de la isoforma L-endoglina humana empleada en este trabajo fue suministrado por el doctor Carmelo Bernabéu (CIB-CSIC, Madrid), en la forma del vector de expresión pCMV5-EndoL (Letamendía et al., 1998a), construido por la inserción del fragmento digerido con EcoR1 de $2.3 \mathrm{kba}$ de cDNA de endoglina procedente de otro vector (pcEXV-EndoL, Bellón et al., 1993) en el plásmido pCMV5 (Invitrogen). En este vector la expresión de endoglina está bajo el control del promotor del citomegalovirus humano. La secuencia nucleotídica de L-endoglina fue asimismo suministrada por el doctor Bernabéu.

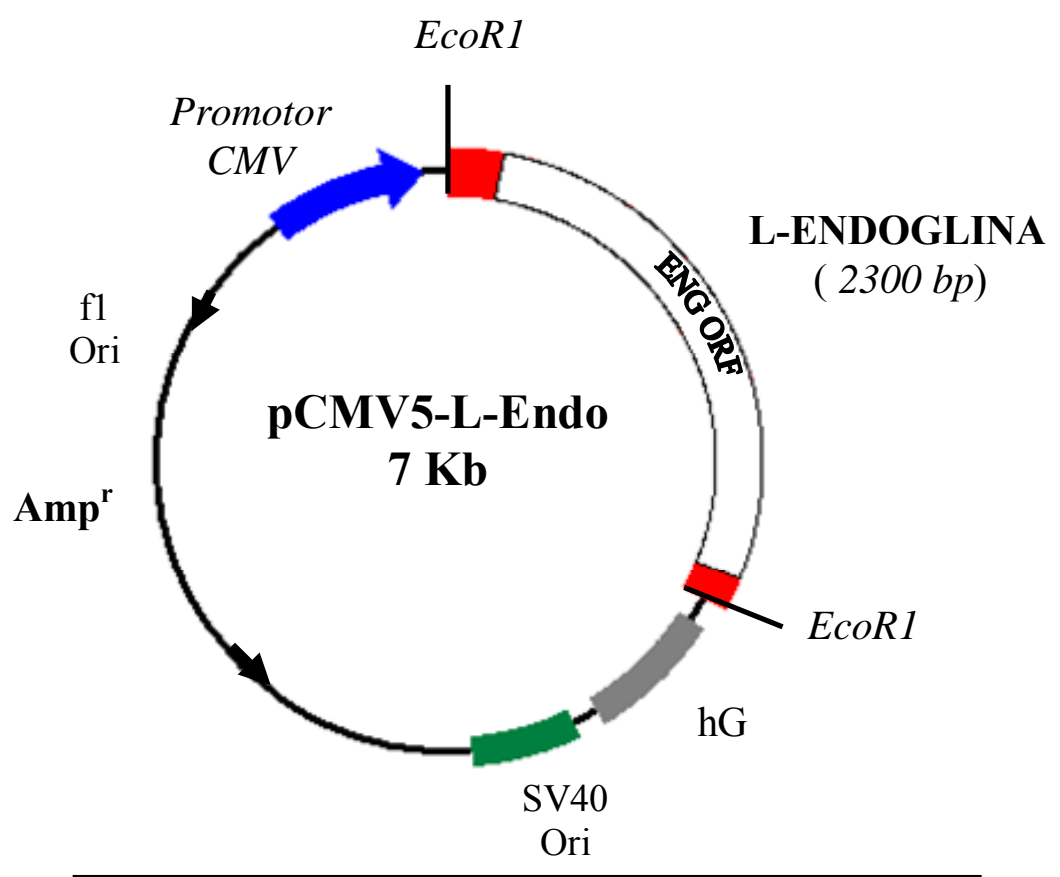

Figura3.5. Mapa del vector pCMV5-EndoL. 


\subsubsection{6. - pCAGGs.}

El plásmido pCAGGs, construido por Niwa et al., (1991) a partir de pUC13, es un potente vector de expresión en células eucariotas, gracias al fuerte promotor de la $\beta$ actina de pollo ayudado por el enhancer del promotor del citomegalovirus humano. Además, contiene el gen de la neomicina fosfotransferasa II bajo un promotor suave, lo que permite su utilización para la selección por resistencia a neomicina de clones que hayan sido transfectados únicamente con un elevado número de copias. Su capacidad de replicación autónoma viene dada por un fragmento que supone el 69\% del virus del papiloma bovino. La Figura 3.6 muestra el mapa y las principales características estructurales del pCAGGs.

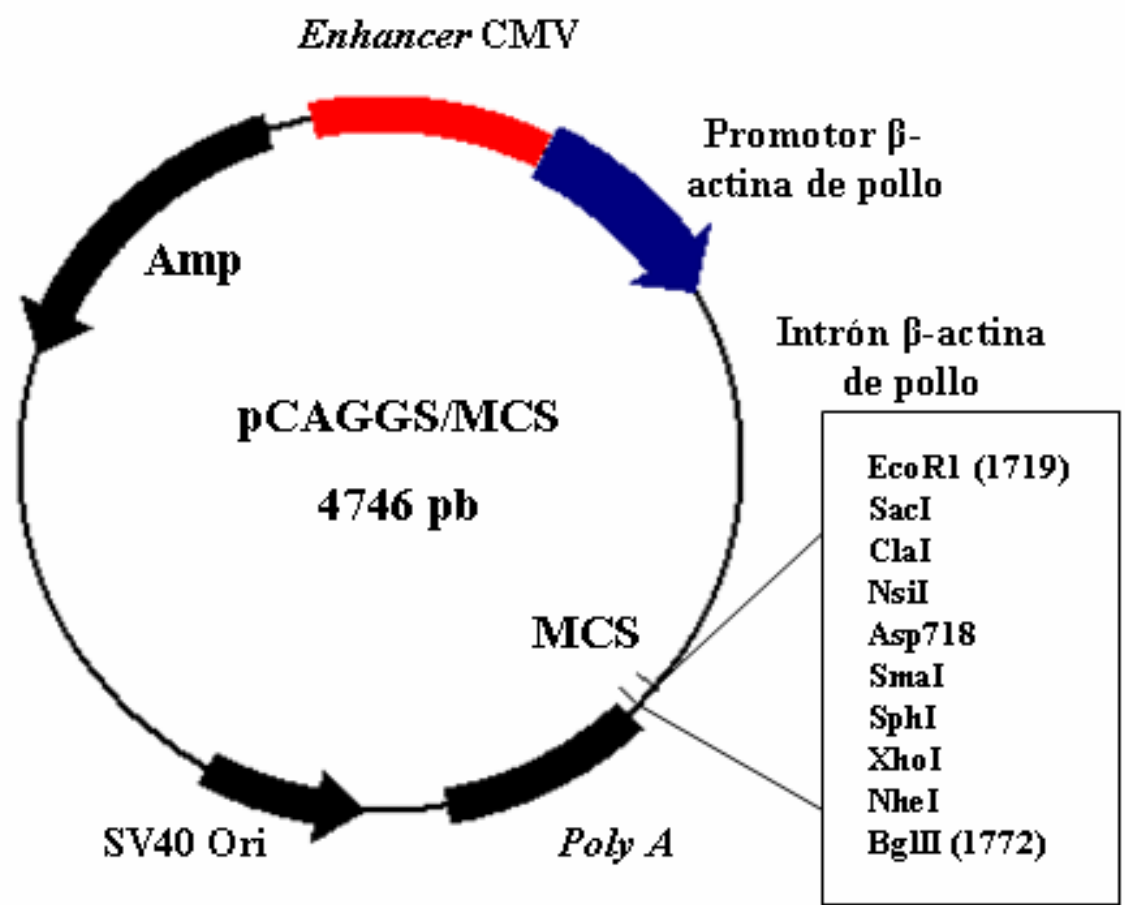

Figura3.6. Mapa del vector pCAGGs

En el presente trabajo, además de emplear el pCACCs como vector de expresión de las proteínas $\mathrm{HN}$ y $\mathrm{F}$ del NDV, se han utilizado otras dos construcciones bajo su mismo promotor: 
pCAGGS-mRFP: plásmido que contiene la ORF de la proteína monomérica roja fluorescente (Campbell et al., 2002). Suministrado por el doctor Adolfo García Sastre (Mount Sinai School of Medicine, NY, E.E.U.U.)

pCAGGS-SC/18 HA: plásmido que contiene la ORF del gen de la hemaglutinina de gripe A/South Carolina/1/18 HA (Glaser et al., 2005), originalmente obtenida a partir del RNA de muestras de un paciente fallecido a causa de la pandemia de gripe de 1918 (Reid et al., 1999) Suministrado por el doctor Adolfo García Sastre (Mount Sinai School of Medicine, NY, E.E.U.U.).

\section{6.- TÉCNICAS DE MANIPULACIÓN DEL DNA.}

\subsection{1.- AISLAMIENTO DEL DNA PLASMÍDICO DE E. coli.}

Para la purificación de DNA plasmídico a partir de cultivos de E.coli se siguió una modificación del procedimiento de lisis alcalina descrito por Birnboim y Doly (1979), seguido de la unión del DNA plasmídico a resinas de intercambio aniónico de QUIAGEN bajo condiciones controladas de $\mathrm{pH}$ y concentración de sales. Este método permite la obtención de DNA suficientemente puro para su posterior uso en la mayoría de las aplicaciones: subclonación, transformación, transfección o secuenciación.

La obtención de DNA plasmídico a pequeña escala se realizó utilizando el kit “QIAprep spin plasmid” siguiendo las especificaciones del fabricante. De 2 a $4 \mathrm{ml}$ de medio TB-ampicilina $(50 \mu \mathrm{g} / \mathrm{ml})$ con E.coli, crecido como se describe en el apartado 3.5.6, se centrifugaron $1 \mathrm{~min}$. Ésta y el resto de centrifugaciones en este método se realizan a máxima velocidad en una centrífuga de mesa (13000 rpm, aproximadamente $10000 \times \mathrm{g}$ ). El sedimento conteniendo las bacterias se resuspendió en $250 \mu 1$ de una solución amortiguadora comercial de dilución con RNAsa A $(100 \mu 1 / \mathrm{ml})$. El DNA se obtuvo por tratamiento con $250 \mu \mathrm{l}$ de una solución compuesta por $\mathrm{NaOH} 200 \mathrm{mM}$ y SDS al $1 \%$ que provoca la lisis bacteriana. Tras $5 \mathrm{~min}$ de incubación a temperatura ambiente, la reacción de lisis se detuvo con la adición de $350 \mu l$ de una solución neutralizante con acetato potásico $3 \mathrm{M}$. La muestra se centrifugó a continuación durante $10 \mathrm{~min}$ y el sobrenadante se pasó entonces a una columna del kit, sobre la que se centrifugó nuevamente $1 \mathrm{~min}$ de forma que el DNA plasmídico disuelto en alta fuerza iónica 
quedase adsorbido en la columna de silicagel. El volumen eluido se desechó y la columna fue lavada con $750 \mu$ de una solución con etanol al $15 \%$, centrifugando de nuevo $1 \mathrm{~min}$, con lo que se retiraron eficientemente las sales. Tras desechar el volumen lavado en este paso, la columna volvió a centrifugarse vacía otro min para eliminar cualquier resto de etanol que pudiera afectar negativamente al rendimiento de los procesos en los que posteriormente se emplease el DNA puro. Finalmente, el DNA se eluyó a baja fuerza iónica añadiendo $30 \mu 1$ de agua ultrapura autoclavada en el centro de la columna, incubando $1 \mathrm{~min}$ a temperatura ambiente y centrifugando $1 \mathrm{~min}$ colocando la columna sobre un vial autoclavado.

Con este procedimiento, se obtuvieron entre 5 y $15 \mu \mathrm{g}$ de DNA puro $\left(\mathrm{DO}_{260 / 280} \geq\right.$ $1,8)$, cantidad que variaba en función del tamaño del plásmido a purificar.

La obtención de DNA plasmídico a gran escala se realizó utilizando el kit “QIAGEN Plasmid Maxi”, siguiendo las indicaciones de la casa comercial, con algunas modificaciones. En esencia, el método es el mismo que se ha descrito anteriormente. Se partió de un cultivo de $400 \mathrm{ml}$ de E. coli en medio LB con ampicilina $(50 \mu \mathrm{g} / \mathrm{ml})$, crecido como se describe en el apartado 3.5.6, que se centrifugó a $5000 \mathrm{rpm}$ en un rotor angular tipo JA-14 o JLA-16.250, 30min a $4^{\circ} \mathrm{C}$. El sedimento se resuspendió en $20 \mathrm{ml}$ de solución comercial con RNAsa A. El volumen resuspendido total fue dividido en dos alícuotas que se pasaron a dos tubos Falcon de $50 \mathrm{ml}$, y a cada uno se añadió $15 \mathrm{ml}$ de solución de lisis. Se agitaron los tubos vigorosamente y se incubaron a temperatura ambiente $5 \mathrm{~min}$, tras los cuales se paró la reacción con $15 \mathrm{ml}$ de solución neutralizante y una nueva agitación. Los tubos se centrifugaron 15min a aproximadamente $3500 \mathrm{rpm}$ en una centrífuga con rotor para tubos Falcon de 50ml, y mientras este paso tenía lugar se equilibraron 2 columnas QIAGEN con $10 \mathrm{ml}$ de solución amortiguadora comercial QBT $(\mathrm{NaCl}$ 0,7M, MOPS 50mM, isopropanol 15\%, triton X-100 0,1\%, pH 7.0). Inmediatamente tras la centrifugación, el sobrenadante de cada tubo se depositó en cada una de las columnas y se dejó pasar a través de la resina por gravedad. Después se lavó la columna 2,5-3 veces con $30 \mathrm{ml}$ de la solución comercial QC ( $\mathrm{NaCl} 1 \mathrm{M}$, MOPS 50mM, isopropanol 15\%, pH 7.0). Finalmente se eluyó el DNA unido a la columna sobre un tubo de ultracentrífuga con $15 \mathrm{ml}$ de solución QF (Tris-HCl 50mM, $\mathrm{NaCl} 1,25 \mathrm{mM}$, isopropanol 15\%, $\mathrm{pH} 8.5$ ). Una vez eluido, se añadieron $12 \mathrm{ml}$ de isopropanol volteando suavemente para precipitar el DNA, e inmediatamente se centrifugó a $20000 \mathrm{rpm}$ y $4^{\circ} \mathrm{C}, 30-40 \mathrm{~min}$, en un rotor oscilante SW- 
28 (Beckman). El sobrenadante se decantó cuidadosamente y se retiraron los restos que pudiera haber con ayuda de una pipeta. Se dejó secar el precipitado al aire brevemente y se combinó el contenido de ambos tubos resuspendiéndolos conjuntamente en $400 \mu 1$ de agua ultrapura autoclavada.

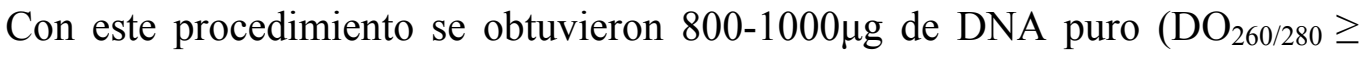
$1,8)$, incluso con los plásmidos de gran tamaño como los pNDV.

\subsection{2.- PURIFICACIÓN DE PLÁSMIDOS EN GRADIENTE CONTÍNUO DE CLORURO DE CESIO.}

La clonación de cualquier inserto en los plásmidos pNDV-B1 y pNDV-F3aa presenta una dificultad añadida debido al gran tamaño de los mismos. Por ello, las preparaciones de estos vectores fueron sometidas a un paso adicional de purificación en gradiente de $\mathrm{CsCl}$ tras haber sido obtenidas mediante el kit "QIAGEN Plasmid Maxi" como se ha descrito anteriormente. La purificación en gradiente de $\mathrm{CsCl}$ es un proceso engorroso y no resulta necesario para la mayoría de las aplicaciones de un plásmido, pero permite obtener un DNA extremadamente puro, lo que en este caso concreto significó un enorme incremento en la eficiencia de clonación.

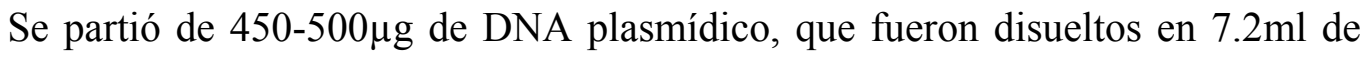
solución amortiguadora TE (Tris 10mM, EDTA 1mM, pH 8.0). Se añadieron 7,5g de $\mathrm{CsCl}$ al tubo y se agitó hasta su completa disolución. A continuación se añadieron $300 \mu 1$ de bromuro de etidio $(10 \mathrm{mg} / \mathrm{ml})$ y el volumen total se trasvasó a un tubo OptiSeal (Beckman Coulter). El resto del tubo se rellenó completamente con parafina y a continuación se selló térmicamente. Los tubos se centrifugaron, tras ser cuidadosamente equilibrados, durante $24 \mathrm{~h}$ a $60.000 \mathrm{rpm}$ y $20^{\circ} \mathrm{C}$ en un rotor de ángulo fijo Beckman 70.1 Ti. Tras la centrifugación aparecieronn claramente visibles dos bandas de color rojo intenso: una superior correspondiente al DNA mellado y una inferior conteniendo el DNA superenrrollado de interés. Esta última banda se extrajo mediante punción del tubo con una aguja hipodérmica, dejando gotear el contenido en un tubo eppendorff. El bromuro de etidio presente en la muestra se retiró mediante seis extracciones consecutivas con $n$-butanol saturado con agua. Finalmente, el DNA se precipitó con la adición de tres volúmenes de etanol al 70\% a uno de muestra, 15min de incubación en hielo y una centrifugación a $10.000 \mathrm{x} \mathrm{g}$ durante $15 \mathrm{~min}$ a $4^{\circ} \mathrm{C}$. El precipitado fue lavado 
con etanol al 70\% y secado al aire, para ser finalmente resuspendido en $200 \mu \mathrm{de} \mathrm{H}_{2} 0$ ultrapura. La pureza y concentración del DNA se analizaron mediante espectofotometría UV y electroforesis en gel de agarosa tal y como se describe a continuación.

\subsection{3.- DETERMINACIÓN DE LA CONCENTRACIÓN DE ÁCIDOS NUCLEICOS.}

La concentración de DNA y RNA fue determinada midiendo la absorbancia a 260nm en un espectrofotómetro GeneQuantpro RNA/DNA Calculator, calculando la relación de absorbancia 260/280 para estimar el grado de pureza de la preparación y considerándose óptima por encima de 1,8 .

Paralelamente, la cantidad y grado de pureza de los plásmidos se comprobó cualitativamente mediante electroforesis en gel de agarosa.

\subsection{4.- ELECTROFORESIS EN GEL DE AGAROSA.}

La separación de los fragmentos de DNA en función de su tamaño se llevó a cabo mediante electroforesis en geles de agarosa, preparados a la concentración adecuada en función de la longitud de los fragmentos a separar, entre 0,6 y 1,5\%. La cantidad precisa de agarosa se disolvió por calentamiento en un horno microondas, en un volumen adecuado de Tris-acetato 40mM, EDTA 1mM (TAE) según el tamaño de la cubeta a emplear. Una vez disuelta la agarosa se añadió bromuro de etidio $(0,5 \mathrm{mg} / \mathrm{ml})$, que al intercalarse en la doble hélice del DNA permite su visualización emitiendo fluorescencia anaranjada al ser excitado con luz ultravioleta. Las muestras se mezclaron con tampón de carga $10 \mathrm{X}(0,25 \%$ de azul de bromofenol, $33 \%$ de Tris $150 \mathrm{mM} \mathrm{pH} 7.6 \mathrm{y}$ $60 \%$ de glicerol), y se depositaron en los pocillos del gel una vez éste hubo solidificado. Los fragmentos migraron a voltaje constante $(50,100$ o $150 \mathrm{~V})$. La solución amortiguadora de carrera fue en todos los casos TAE.

Las imágenes de los geles se obtuvieron sobre un transiluminador de luz ultravioleta con cámaras Kodak DC120, Kodak GL-100 y Polaroid Electrophoresis Systems FB-PDC-34, y fueron procesadas mediante el programa "Kodak Digital Science "v 3.0 . 


\subsection{5.- DIGESTIÓN CON ENDONUCLEASAS DE RESTRICCIÓN.}

Para la clonación de los insertos en los correspondientes vectores se procedió a la digestión ambos con las enzimas de restricción adecuadas. En el caso de los productos de PCR se añadieron a $25 \mu$ l procedentes del paso de purificación con "QIAquick PCR purification kit" (ver apartado 3.6.10), 2,5 $\mu 1$ de cada una de las endonucleasas deseadas y $5 \mu 1$ de la solución amortiguadora $10 \mathrm{X}$ indicada por la casa comercial (Promega o New England Biolabs) como la más adecuada para esas enzimas .El volumen total a $50 \mu \mathrm{l}$ con $\mathrm{H}_{2} \mathrm{O}$ ultrapura. La reacción se incubó a $37^{\circ} \mathrm{C}$, la temperatura de digestión óptima para todas las enzimas empleadas en el presente trabajo, durante 2-4 horas, y posteriormente todo el volumen se sometió a una electroforesis en gel de agarosa de donde el fragmento deseado sería purificado como se describe en el apartado 3.6.7.

En el caso de los vectores, $4 \mu \mathrm{g}$ de vector obtenidos con el kit "QIAGEN Plasmid Maxi" como se menciona en el apartado 3.6.1, se digirieron en un volumen total de $50 \mu l$ con $5 \mu 1$ de solución amortiguadora $10 \mathrm{X}$ y $2,5 \mu \mathrm{l}$ de enzima, incubándose la muestra de reacción a $37^{\circ} \mathrm{C}$ durante $2-4$ horas. De ese volumen, $5 \mu 1$ se emplearon para comprobar si efectivamente se había producido la linealización del vector mediante electroforesis en gel de agarosa, tras lo cual el resto del volumen fue sometido a tratamiento con fosfatasa alcalina como se describe a continuación.

Este mismo procedimiento se empleó para el análisis de los patrones de digestión de los nuevos clones y mutantes obtenidos.

\subsection{6.- TRATAMIENTO CON FOSFATASA ALCALINA (CIP).}

Los fenómenos de recircularización de los vectores son una importante fuente de trasfondo no deseado en los procesos de clonación, especialmente si dichos vectores han sido digeridos con una única endonucleasa de restricción. La estrategia para minimizar ese problema implica la eliminación de los grupos fosfato de los extremos 5' de una cadena de DNA lineal por tratamiento con una fosfatasa, de forma que durante la ligación sólo se pueda restituir uno de los dos enlaces fosfodiéster rotos en la digestión, lo que produce hebras melladas y mucho más inestables.

En el presente trabajo se empleó la fosfatasa alcalina de intestino de cordero (CIP). Se partió de $45 \mu 1$ de vector digerido como se menciona en el apartado anterior, y 
directamente se les añadieron $5 \mu 1$ de CIP (NEB). La solución amortiguadora empleada con cualquiera de las enzimas de restricción permite también la desfosforilación con $\mathrm{CIP}$, por lo que no es precisa ninguna adición más. La reacción se incubó 1 hora a $37^{\circ} \mathrm{C}$, tras la cual se añadieron otros $2,5 \mu 1$ de CIP y se incubó 30min más. Finalmente se inactivó la mezcla de reacción incubándola a $65^{\circ} \mathrm{C}$ durante $10 \mathrm{~min}$. El vector así desfosforilado se sometió posteriormente a electroforesis en gel de agarosa y la banda de interés se purificó tal y como se describe en el apartado siguiente.

Cabe destacar que el tratamiento con CIP no elimina totalmente el trasfondo por vector recircularizado, ya que la mella que se produce tras una ligación incompleta a consecuencia de este tratamiento puede ser reparada por las bacterias competentes tras la transformación. Además, es frecuente que las soluciones comerciales de CIP contengan exonucleasas que degraden en parte los extremos de los vectores, llevando a un menor rendimiento de la clonación. Por todo ello, durante el presente trabajo también se probó a realizar ligaciones y transformaciones con vectores sin desfosforilar, pero se obtuvieron trasfondos tan grandes que hacían muy complicado encontrar las colonias correctas, por lo que finalmente se optó por la desfosforilación en todos los casos, incluso cuando los extremos a clonar no fueron compatibles.

\subsection{7.- EXTRACCIÓN Y PURIFICACIÓN DE DNA DESDE GELES DE AGAROSA.}

El aislamiento y la purificación de los fragmentos de DNA de interés desde geles de agarosa se realizó cortando la banda deseada con un escalpelo mientras se visualizaba con un transiluminador de luz ultravioleta. Esta porción de agarosa fue procesada con el kit “QIAquick Gel Extraction”, que consiste esencialmente en una cromatografía de intercambio iónico similar a las empleadas en los kits descritos en el apartado 3.6.1.

Se añadieron $600 \mu \mathrm{l}$ de solución QG a la banda cortada, y se incubó a $37^{\circ} \mathrm{C}$, agitando regularmente hasta que la agrosa fue totalmente digerida. Posteriormente, se pasó la muestra por una de las columnas del kit, centrifugando 1 minuto a $13000 \mathrm{rpm}$ en una centrífuga de mesa. Con este paso el DNA queda adsorbido a la silicagel. Después se lavó la columna con $750 \mu 1$ de solución PE, con etanol para retirar sales, centrifugando $1 \mathrm{~min}$ a $13000 \mathrm{rpm}$, centrifugación que fue seguida, tras retirar el volumen lavado, por otra igual que retiró cualquier resto de etanol. Finalmente, el DNA ya puro 
se eluyó a baja fuerza iónica depositando $30 \mu 1$ de agua ultrapura autoclavada en el centro de la columna, incubando durante $1 \mathrm{~min}$ a temperatura ambiente y centrifugando a $13000 \mathrm{rpm}, 1 \mathrm{~min}$.

Las soluciones empleadas (QG, PE) fueron suministradas con el kit comercial y se desconoce su composición exacta.

\subsection{8.- DISEÑO DE OLIGONUCLEÓTIDOS PARA LA REACCIÓN EN CADENA DE LA POLIMERASA (PCR).}

\subsubsection{1.- Clonación de la ORF de la endoglina en pNDV-B1 y pNDV-F3aa.}

Para el diseño de oligonucleótidos se utilizó la información suministrada por el Dr. Carmelo Bernabéu acerca de la secuencia de la endoglina en pCMV5-EndoL. Esta secuencia se analizó para comprobar la ausencia de sitios de restricción similares a los que iban a introducirse para la clonación con el programa Webcutter 2.0, (http://rna.lundberg.gu.se/cutter2/). Una vez confirmado este punto, se procedió al diseño de los cebadores, teniendo en cuenta los siguientes aspectos:

- La incorporación del gen al genoma viral no debía afectar a la lectura del mismo. Debían respetarse las señales que se sabe regulan ésta, y al tratarse sólo de unos pocos nucleótidos la manera más fácil de hacerlo es añadirlos a los cebadores que van a permitir la amplificación por PCR de forma que durante la misma las nuevas secuencias queden incorporadas a los fragmentos amplificados. Así pues se incluyeron, después de la secuencia de reconocimiento para la enzima de restricción correspondiente pero antes del codón de iniciación, las secuencias reguladoras correspondientes a la finalización de la lectura del gen anterior (GE) y al inicio de la del gen siguiente (GS), así como un nucleótido intercistrónico de separación entre ambas, lo que constituye una secuencia intergénica (IS) válida. Del mismo modo, se añadieron 7 nucleótidos inmediatamente aguas arriba del codón de iniciación que constituyeran una secuencia Kozak óptima, lo que estimula la traducción en células eucariotas.

- Al extremo 3' de la fase de lectura abierta (ORF) de endoglina se añadieron el número preciso de nucleótidos, tras el codón de terminación y antes del sitio de restricción, para que tras la inclusión del inserto la longitud del genoma vírico siguiera siendo múltiplo de 6. Este hecho, conocido como la "regla del 6", es básico para la eficiente replicación de los paramixovirus como se comentó en el apartado 1.2.3.2. Para 
calcular el número de nucleótidos que se estaban introduciendo, se tuvo en cuenta tanto el tamaño de la ORF de endoglina como las adiciones aguas arriba que se han mencionado anteriormente, y para clonar el dominio extracelular se contabilizó tanto éste como los dominios transmembrana y citoplasmático de la proteína F del NDV, que iban a ser clonados conjuntamente con él.
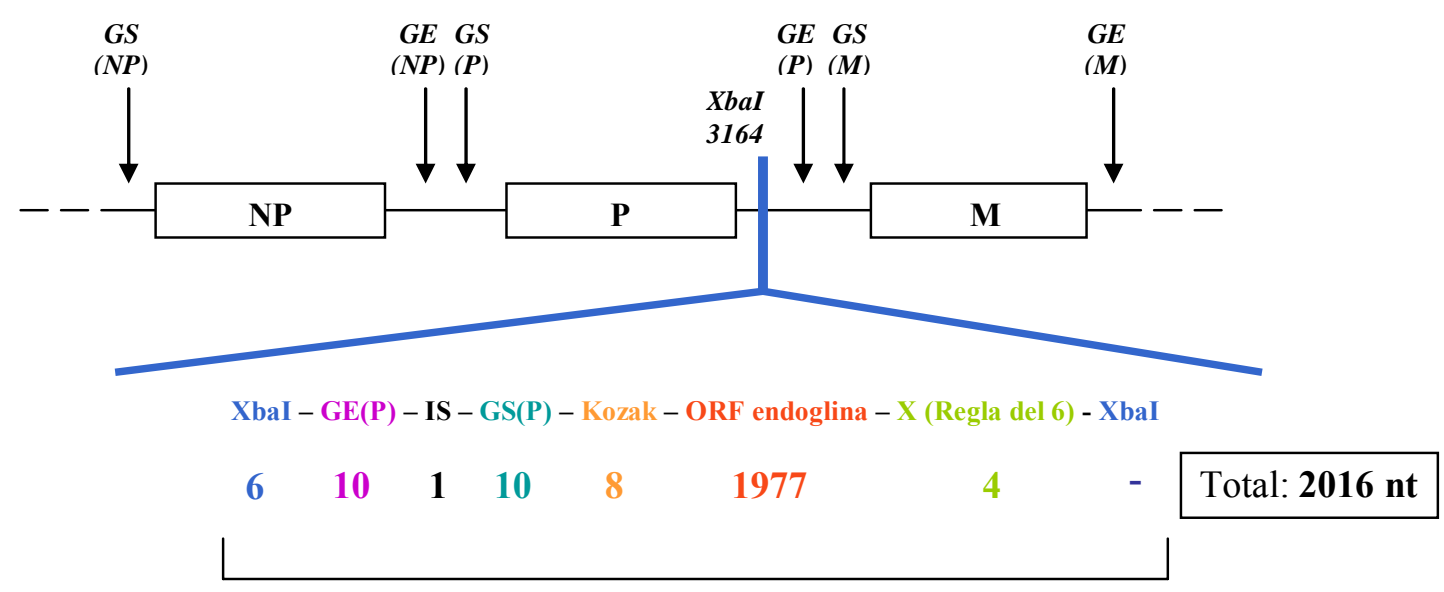

A

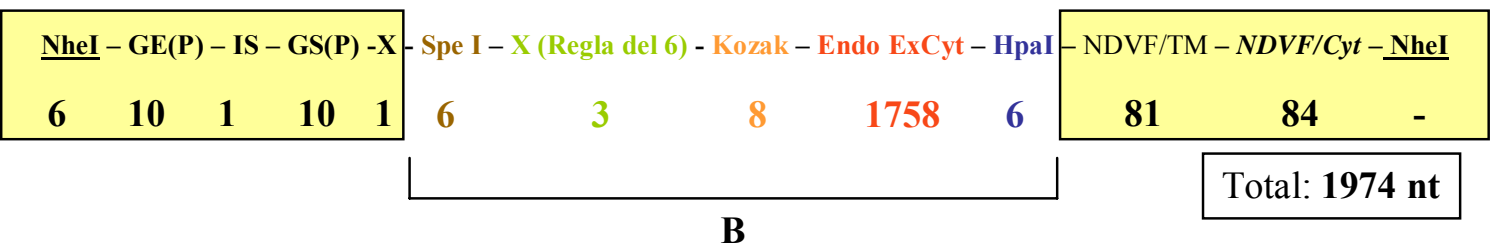

Figura3.7.- Estrategias de clonación en pNDV. (A).- Secuencias introducidas para clonar la ORF entera de endoglina, y longitud de cada una de ellas. (B).- Secuencias introducidas para clonar la quimera Endo/NDV-F/TMCyt. Las enmarcadas en amarillo no fueron amplificadas por PCR: se incorporarían en el vector lanzadera (ver apartado 3.5.7.4), pero su longitud se tuvo en cuenta para el cálculo del número total de nucleótidos: obsérvese que éste es en ambos casos múltiplo de 6, para lo que se añadieron al diseñar los cebadores 4 y 3 nucleótidos respectivamente

- Los fragmentos resultantes de la PCR iban a ser digeridos inmediatamente tras ésta. Puesto que los sitios de restricción estarían justo en los extremos de las cadenas amplificadas, era preciso añadir un pequeño número de nucleótidos para que la unión de las endonucleasas a su secuencia objetivo fuese posible. Dicho número se seleccionó siguiendo la información al respecto ofrecida por la casa comercial a la que se adquirieron las enzimas (Promega o New England Biolabs). Dado que estos nucleótidos se encontrarían en el extremo $5^{\prime}$ de las secuencias de restricción y por tanto no se 
incorporarían finalmente al genoma vírico, no fueron tenidos en cuenta para el cálculo de la regla del 6

Esta estrategia de clonación se resume en la Figura3.7. Los oligonucleótidos diseñados se muestran en la Tabla 3.2A.

Tabla 3.2.- Secuencias de los oligonucleótidos cebadores para PCR. (A) Oligonucleótidos para la amplificación de endoglina y su dominio extracelular. Se ha mantenido el código de colores de la Figura3.7. Los cebadores Endo/XbaI/frwrd y Endo/XbaI/rev se diseñaron para la amplificación de la ORF completa de endoglina; los cebadores EExC/SpeI/frwrd y EExC/HpaI/rev para la selectiva amplificación del dominio extracelular de la proteína y su posterior clonación en el vector lanzadera pGEM- NDV-F\TMCyt. (B) Oligonucleótidos para la amplificación de los genes HN y F del NDV Hitchner B1. La secuencia complementaria del cDNA del virus aparece en rojo; los sitios de restricción a añadir se muestran subrayados.

A

\begin{tabular}{|c|c|c|c|}
\hline Nombre & Oligonucleótido $\left(5^{\prime}-3^{\prime}\right)$ & $\begin{array}{l}\text { Nucleótidos } \\
\text { complementarios } \\
\text { en ORF de } \\
\text { endoglina }\end{array}$ & $\begin{array}{l}\text { Sitio de } \\
\text { reconocimiento }\end{array}$ \\
\hline Endo/XbaL/frwrd & $\begin{array}{l}\text { CGTCTAGATTAGAAAAAATACGGGTAGAACCGCCA } \\
\text { CCATGGACCGCGGCACGCTCCCTC }\end{array}$ & $1-22$ & XbaI \\
\hline Endo/XbaI/rev & CGTCTAGAGGGGCTATGCCATGCTGCTGGTGGAG & $1956-1977$ & XbaI \\
\hline EExC/SpeI/frwrd & $\begin{array}{l}\text { CCGGACTAGTCGACCGCCACCATGGACCGCGGCA } \\
\text { CGCTCCCTC }\end{array}$ & $1-22$ & SpeI \\
\hline EExC/HpaI/rev & CCCCGGGTTAACGCCTTTGCTTGGCAACCAGAC & $1737-1758$ & HpaI \\
\hline Nombre & Oligonucleótido $\left(5^{\prime}-3^{\prime}\right)$ & $\begin{array}{c}\text { Nucleótidos } \\
\text { complementarios } \\
\text { en ORF de F/HN }\end{array}$ & $\begin{array}{l}\text { Sitio de } \\
\text { reconocimiento }\end{array}$ \\
\hline F/ClaI/frwrd & GCGCATCGATATAATGGGCTCCAGACCTTCT & $1-18$ & ClaI \\
\hline F/BglIII/rev & CGGGAGATCTTCACATTTTTGTAGTGGC & $1645-1662$ & BglIII \\
\hline $\mathrm{HN} / \mathrm{ClaI} /$ frwrd & GCGCATCGATATAATGGACCGCGCAGTTAGC & $1-18$ & ClaI \\
\hline HN/BglIII/rev & CGAGAGATCTCTAGCCAGACCTGGCTTCTC & $1715-1734$ & BglIII \\
\hline
\end{tabular}




\subsubsection{2.- Clonación de las ORF de HN y F en pCAGGs}

Tras analizar el mapa de restricción de los genes de las proteínas $\mathrm{F}$ y HN del NDV de la cepa B1 se decidió clonarlos entre los sitios ClaI y BglIII de la región de clonación múltiple de pCAGGs (ver Figura3.6). Los oligonucleótidos se diseñaron a partir de la secuencia del pNDV-B1 (GenBank, AF375823) de forma que incluyeran los nuevos sitios de restricción. Sus secuencias se muestran en la Tabla 3.2.B. Todos los cebadores empleados para PCR en este trabajo se obtuvieron de la casa comercial Invitrogen.

\subsection{9.- REACCIÓN EN CADENA DE LA POLIMERASA (PCR)}

La reacción en cadena de la polimerasa permite la amplificación exponencial de moléculas de DNA a lo largo de una serie de pasos sucesivos (ciclos) en unas condiciones determinadas de tiempo y temperatura. En esencia, la técnica se basa en el proceso natural de replicación; la diferencia radica en el uso de polimerasas resistentes a esos incrementos sustanciales de temperatura. Gracias a este sistema pueden obtenerse en poco tiempo, y partiendo de una muy pequeña cantidad de molde, un gran número de moléculas. Puesto que se amplifican selectivamente las partes del molde comprendidas entre los oligonucleótidos cebadores, éstos pueden diseñarse específicamente para extraer genes enteros de los vectores en que se encuentren y modificarlos añadiendo secuencias en sus extremos, como se realizó en el presente trabajo. La PCR se trata, por tanto, de una herramienta de gran utilidad en la clonación.

La reacción se inicia con un paso de desnaturalización a alta temperatura que separa las dos hebras de la molécula molde de DNA; un segundo paso, a una temperatura menor, lleva al anillamiento de los oligonucleótidos cebadores con sus secuencias complementarias en el molde desnaturalizado, de forma que presentan un hidroxilo en posición 3' disponible para que la polimerasa vaya añadiendo nucleótidos y completando la hebra. Este paso es el de elongación, y su duración depende de la longitud del fragmento que se persigue amplificar $(\sim 1 \mathrm{~min}$ por $\mathrm{Kb})$. Estos tres pasos se van repitiendo sucesivamente a lo largo de un determinado número de ciclos, de forma que al final la población de moléculas de DNA de la muestra esté casi exclusivamente formada por el fragmento específicamente amplificado. 
Las reacciones de PCR en el presente trabajo se realizaron co el kit "Expand High Fidelity PCR System" (Roche), que suministra una mezcla enzimática de las polimerasas de DNA Taq y Pwo. En cada reacción, para un volumen total de 50 $\mu$, se emplearon 100ng de DNA molde, $2,5 \mu 1$ de cada uno de los cebadores $(50 \mathrm{ng} / \mu \mathrm{l}), 5 \mu \mathrm{l}$ de la solución mortiguadora de reacción 10X suministrada con el kit, $6 \mu 1$ de una solución de $\mathrm{MgCl}_{2} 25 \mathrm{mM}, 2 \mu \mathrm{l}$ de una mezcla de dNTPs $10 \mathrm{mM}$ y $0,25 \mu 1$ de mezcla enzimática.

La reacción tuvo lugar según el siguiente programa:

$1^{\circ}$ - Calentamiento inicial para desnaturalización parcial, a $94^{\circ} \mathrm{C}, 5 \mathrm{~min}$

$2^{\circ}$ - 30 ciclos sucesivos con desnaturalización a $94^{\circ} \mathrm{C}, 1 \mathrm{~min}$; anillamiento de los cebadores a $55^{\circ} \mathrm{C}, 1 \mathrm{~min}$, y elongación a $72^{\circ} \mathrm{C}, 2 \mathrm{~min}$

$3^{\circ}$ - Un último paso de elongación para completar definitivamente los dúplex de DNA, con calentamiento a $72^{\circ} \mathrm{C}, 10 \mathrm{~min}$

$4^{\circ}$ - Finalmente, enfriamiento para la conservación del DNA a $4^{\circ} \mathrm{C}$.

\subsubsection{0.- PURIFICACIÓN DEL PRODUCTO DE LA PCR.}

Los fragmentos de DNA resultantes de la PCR fueron purificados con el kit “QIAquick PCR Purification”, que emplea el mismo sistema que el descrito en el apartado 3.6.1. Este kit permite la retirada rápida y eficiente de los restos de dNTPs, oligonucleótidos cebadores y enzimas, permitiendo la recuperación de más del $80 \%$ del DNA puro y preparado para su subsiguiente manipulación.

Se añadieron 5 volúmenes de solución amortiguadora PB a 1 volumen de la mezcla de reacción de PCR, y el conjunto se centrifugó por una de las columnas del kit a $13000 \mathrm{rpm}, 1 \mathrm{~min}$, permitiendo la adsorción del DNA a la silicagel. El resto del protocolo fue como se describe en el apartado 3.6.6: un paso de lavado con una solución con etanol, la eliminación de todo residuo de ésta, y la elución con $50 \mu 1$ de agua ultrapura.

Se desconoce la composición exacta de la solución $\mathrm{PB}$, así como del resto de las empleadas. 


\subsubsection{1.- CONSTRUCCIÓN DE PLÁSMIDOS RECOMBINANTES.}

Las moléculas recombinantes se obtuvieron mediante la combinación de fragmentos de DNA purificados, uno de los cuales fue siempre un vector plasmídico. Tanto los insertos como los vectores habían sido previamente digeridos por las endonucleasas de restricción precisas de forma que compartieran extremos cohesivos. En todos los casos salvo en el mencionado en el apartado siguiente, los vectores se trataron con fosfatasa alcalina para impedir su religación.

En la reacción de ligación se utilizó el kit comercial "Rapid DNA Ligation Kit" (Roche), que permite una reacción eficiente con tan sólo 20min de incubación a temperatura ambiente. En primer lugar se diluyeron $2 \mu 1$ de vector y de 2 a $8 \mu l$ de inserto, para probar un intervalo variado de relaciones vector:inserto, en la solución amortiguadora de dilución del kit $5 \mathrm{X}$ y agua ultrapura hasta un volumen de $15 \mu \mathrm{l}$. Posteriormente se añadieron $15 \mu \mathrm{l}$ de solución amortiguadora de ligación $2 \mathrm{X}$ y $1 \mu \mathrm{l}$ de ligasa del fago T4. Se incubó la mezcla 20min a temperatura ambiente. Acto seguido se utilizó la totalidad de la reacción para transformar E.coli y recuperar de este modo los plásmidos recombinantes.

\subsubsection{2.- CLONACIÓN DE PRODUCTOS DE PCR EN EL VECTOR pGEM-T.}

El vector comercial pGEM-T (Promega) permite la clonación directa de los productos de PCR en los que se incorpore un resto solitario de desoxiadenosina en el extremo 3', lo que llevan a cabo la mayor parte de las polimerasas de uso corriente. El vector se vende ya linealizado y con desoxitimidinas terminales en $3^{\prime}$, de forma que no se puede recircularizar salvo incorporando el fragmento deseado. Además, la región de clonación está incluida dentro de la secuencia que codifica la enzima $\beta$-galactosidasa, de modo que es posible la selección de clones recombinantes basándose en el color de las colonias de la placa en presencia del inductor IPTG (isopropil- $\beta$-D-tiogalactopiranósido, Promega) y del sustrato X-Gal (5-bromo-4-cloro-3-indolil- $\beta$-D-galactopiranósido). Si un inserto se ha introducido e interrumpido la ORF de la $\beta$-galactosidasa, las colonias serán blancas; si el vector se ha recircularizado pero sin inserto se expresará la enzima en las bacterias transformadas y las colonias resultantes serán azules por la rotura de XGal. 
La clonación directa en el vector pGEM-T (ver apartado 3.5.7.2.), aun cuando no sea el vector definitivo en que se desea clonar un producto de PCR, presenta las ventajas de la rapidez y la eficiencia, permite una rápida selección de los clones positivos y facilita la secuenciación de los insertos y el corte por endonucleasas en sitios añadidos al extremo de los fragmentos amplificados, como en el caso de este trabajo. Además. es posible multiplicar en cultivo las bacterias transformadas con esta construcción para obtener grandes cantidades de inserto en caso necesario sin tener que recurrir a nuevas PCR. Por todo ello se decidió llevar a cabo esta clonación al mismo tiempo que se intentaba la que había de producir los plásmidos recombinantes definitivos, descrita en el apartado anterior.

Para la reacción de ligación se empleo la ligasa del fago T4, incluida en el kit de pGEM-T. Se añadieron $2 \mu 1$ de pGEM-T, $10 \mu 1$ de solución amortiguadora $10 \mathrm{X}, 1 \mu 1$ de ligasa y distintos volúmenes de producto de PCR purificada según describe el apartado anterior, para tener distintas relaciones vector:inserto y detectar la más eficiente. Se ajustó la reacción a un volumen total de $20 \mu$ con agua ultrapura autoclavada, y se incubó durante una noche a $4^{\circ} \mathrm{C}$, tras lo que se procedió a la transformación de bacterias competentes.

\subsubsection{3.- TRANSFORMACIÓN DE E. coli DH5a.}

Se descongelaron $200 \mu \mathrm{l}$ de Escherichia coli DH5 $\alpha$ competentes en hielo y se añadieron a la mezcla de ligación. Se incubaron 5 min en hielo e inmediatamente se sometió a las células a un choque térmico en un baño a $42^{\circ} \mathrm{C}$ durante 1 min seguido de 5 min de incubación en hielo. Posteriormente se añadieron $800 \mu$ de medio SOC y la mezcla se incubó a $30^{\circ} \mathrm{C}$ durante 1 hora y en agitación, para que las células que hubiesen adquirido el plásmido expresasen la resistencia a la ampicilina en él codificada y reconstituyeran sus membranas y paredes tras el choque térmico. Finalmente, las bacterias transformadas se sedimentaron por centrifugación 1min a $13000 \mathrm{rpm}$, fueron resuspendidas en $100 \mu \mathrm{l}$ de medio SOC y se sembraron en esterilidad en placas Petri de LB-agar en presencia de ampicilina $(50 \mu \mathrm{g} / \mu \mathrm{l})$. En el caso de que la transformación implicara al vector pGEM-T, las placas fueron suplementadas 30min antes de la siembra con $20 \mu \mathrm{l}$ de X-Gal $(50 \mathrm{mg} / \mathrm{ml})$ y $100 \mu \mathrm{l}$ de IPTG $(100 \mathrm{mM})$. Las placas se incubaron a $30^{\circ} \mathrm{C}$ entre 12 y 24 horas. 


\subsubsection{4.- SELECCIÓN DE CLONES POR PCR SOBRE COLONIAS.}

El fundamento de esta técnica radica en la posibilidad de añadir una colonia bacteriana de un tamaño adecuado directamente desde la placa de cultivo a una mezcla de reacción de PCR, y obtener amplificación de un fragmento de DNA deseado. Dada la gran sensibilidad de la PCR no es preciso multiplicar en cultivo las colonias, y se pueden analizar un gran número de ellas con poco tiempo y esfuerzo. El método permite también detectar, en un único paso, si el inserto ha sido clonado con la polaridad correcta. Para ello se requiere que del par de cebadores empleados uno anille dentro del inserto y otro en una región del vector, de forma que sólo se produzca amplificación si la entrada del inserto se ha producido de manera que los cebadores flanqueen la zona a amplificar.

Se usó el kit "Expand High Fidelity PCR System" tal y como se ha descrito en el apartado 3.6.9. Se preparó una mezcla de reacción para PCR, con un volumen final adecuado al número total de colonias que se pretendía analizar: por cada una de éstas se añadieron $2,5 \mu \mathrm{l}$ de cada uno de los cebadores $(50 \mathrm{ng} / \mu \mathrm{l}), 5 \mu \mathrm{l}$ de la solución amortiguadora de reacción $10 \mathrm{X}$ suministrada con el kit, $6 \mu \mathrm{l}$ de una solución de $\mathrm{MgCl}_{2}$ $25 \mathrm{mM}, 2 \mu \mathrm{l}$ de una mezcla de dNTPs $10 \mathrm{mM}, 0,25 \mu \mathrm{l}$ de mezcla enzimática y $32 \mu \mathrm{l}$ de agua ultrapura autoclavada. Las colonias, con un diámetro mínimo de $2 \mathrm{~mm}$, se picaron con una punta autoclavada de pipeta y se sumergieron en $50 \mu 1$ de la mezcla de reacción con una breve agitación. La misma punta de pipeta se empleó para hacer una réplica de cada colonia en placa, de forma que pudieran reutilizarse los clones que resultaran positivos. Las placas de réplica se incubaron durante toda la noche a $30^{\circ} \mathrm{C}$.

Los cebadores se seleccionaron según cada caso de entre los descritos en la Tabla 3.4. La reacción de PCR se llevo a cabo con el mismo programa del apartado 3.6.9, con la única diferencia de que en este caso, al ser menor el fragmento a amplificar, cada paso de elongación a $72^{\circ} \mathrm{C}$ sólo duraba $1 \mathrm{~min}$ Tras la finalización de la reacción, se cargaron las muestras en un gel de agarosa para comprobar los clones positivos por electroforesis.

\subsubsection{5.- MUTAGÉNESIS DIRIGIDA.}

Para introducir las mutaciones deseadas en el gen de la proteína $\mathrm{F}$ del NDV/Hitchner B1, se utilizó el kit comercial "QuickChange Site-Directed 
Mutagenesis II" (Stratagene), que contiene la DNA polimerasa "Pfu Turbo", capaz de replicar las dos hebras del DNA plasmídico con una alta eficiencia.

El proceso utiliza un vector de DNA con doble cadena con la ORF de interés que se quiere mutar y dos oligonucleótidos sintéticos que contienen la mutación deseada. Los oligonucleótidos se diseñan para la misma región, cada uno complementario de una de las dos hebras del vector. La acción de la DNA polimerasa expande los cebadores generándose plásmidos mutados. Después se trata el producto con la endonucleasa DpnI, que digiere exclusivamente el DNA metilado o semimetilado. Dado que los plásmidos empleados como molde proceden de cultivos de E. coli, éstos se encuentran metilados por acción de las metilasas dam y dcm y serán degradados por DpnI. Los plásmidos mutados, originados de novo por la PCR, quedarán intactos. El producto de la digestión es posteriormente empleado para transformar bacterias competentes Epicurian coli XL1-blue, amplificándose selectivamente sólo los plásmidos mutados.

En la reacción de mutagénesis se emplearon 50ng de DNA molde, 75ng de cada uno de los oligonucleótidos cebadores, $1 \mu 1$ de de la mezcla de dNTPs suministrada con el kit y $5 \mu 1$ de la solución amortiguadora de la reacción $10 \mathrm{X}$, todo ello ajustado a un volumen de $50 \mu 1$ con agua ultrapura. Finalmente se añadieron $2,5 \mu 1$ de la polimerasa "Pfu Turbo" y se procedió a realizar una PCR con las siguientes condiciones: desnaturalización a $95^{\circ} \mathrm{C}$ durante 5 min seguida por 20 ciclos de calentamiento a $95^{\circ} \mathrm{C}$ (1min), acoplamiento de los cebadores a $55^{\circ} \mathrm{C}(1 \mathrm{~min})$ y elongación a $68^{\circ} \mathrm{C}(10 \mathrm{~min})$, finalizando con un último paso de elongación a $68^{\circ} \mathrm{C}$ de $10 \mathrm{~min}$ para completar las hebras recién sintetizadas. Tras la reacción, $10 \mu 1$ del volumen de la misma se sometieron a electroforesis en gel de agarosa para comprobar la amplificación, hecho lo cual se añadieron $10 \mu 1$ de la enzima DpnI y se dejó digerir el DNA durante $1 \mathrm{~h}$ a $37^{\circ} \mathrm{C}$. Finalmente se empleó $1 \mu 1$ volumen de la reacción de digestión para transformar $50 \mu 1$ de bacterias Epicurian coli XL1-blue. Se analizaron los patrones de digestión de distintos clones, pudiéndose encontrar los mutantes gracias a nuevas marcas de restricción introducidas junto a las mutaciones deseadas. Finalmente, se comprobó la integridad de todas las nuevas ORF mutadas por secuenciación. Los oligonucleótidos empleados en esta serie de mutagénesis se muestran en la Tabla 3.3, junto con las nuevas marcas de restricción introducidas. 


\subsubsection{EXTRACCIÓN DE RNA.}

La extracción del RNA total procedente de células infectadas o viriones purificados se realizó empleando el reactivo TRIzol (Invitrogen), consistente en una solución monofásica de fenol e isocianato de guanidina. El procedimiento seguido, de acuerdo con las instrucciones del fabricante, es una modificación del descrito por Chomczynski y Sacchi (1987). Básicamente, consiste en un primer paso de lisis y homogeneización del material de partida, seguido de una extracción con cloroformo y finalmente la precipitación con isopropanol del RNA presente en la fase acuosa.

Para la extracción del RNA de células infectadas se partió de placas de $100 \mathrm{~mm}$ con células Vero confluentes, que fueron infectadas con los distintos virus a una m.o.i. de 1 (ver apartado 3.8.1.1 más adelante: en este caso el volumen del inóculo fue de $1 \mathrm{ml}$ de PBS/BA/PS). Pasadas 24h postinfección las placas se lavaron con PBS y las células se levantaron en $1 \mathrm{ml}$ de TRIzol con ayuda de un raspador y se pasaron a un vial. Tras agitar la mezcla vigorosamente se incubó $5 \mathrm{~min}$ a temperatura ambiente. Posteriormente se añadieron $200 \mu 1$ de cloroformo, se agitó al vórtex 15 segundos y se dejó reposar durante $3 \mathrm{~min}$. Las fases acuosa y orgánica se separaron mediante centrifugación $15 \mathrm{~min}$ a máxima velocidad en una centrífuga de mesa y la fase acuosa resultante, la superior, se trasvasó a un nuevo vial. Se le añadieron $500 \mu l$ de isopropanol y se incubó la muestra en reposo 10min. El RNA precipitado resultante se sedimentó por centrifugación 10min y se lavó con $75 \%$ etanol antes de ser finalmente resuspendido en $\mathrm{H}_{2} \mathrm{O}$ ultrapura autoclavada. La concentración y el grado de pureza del RNA obtenido se analizaron según se describe en el apartado 3.6.3.

Para la extracción del RNA procedente de los viriones se partió de $200 \mu \mathrm{l}$ de virus purificado como se describe más adelante en el apartado 3.7.6, a los que se añadió $1 \mathrm{ml}$ de TRIzol para su homogeneización. Los pasos subsiguientes fueron iguales a los descritos para la extracción de RNA celular.

\subsubsection{RT-PCR.}

La RT-PCR (del inglés "Reverse Transcription-Polymerase Chain Reaction": reacción de transcripción inversa seguida de una reacción en cadena de la polimerasa) es una técnica que permite amplificar una secuencia génica o parte de ésta a partir de la información contenida en el RNA. En un proceso que conlleva dos pasos consecutivos: 
primero, el RNA es sometido a una transcripción inversa de su secuencia produciéndose una copia de DNA complementario o cDNA, que es a su vez amplificado en el segundo paso mediante una PCR convencional.

Tabla 3.3.- Oligonucleótidos empleados en mutagénesis dirigida. Se indica cada sustitución aminoacídica, la región de la proteína $F$ en que se localiza (ver figs. 1.6 y 4.22), la marca de restricción empleada en la selección de los clones (bien introducida en la mutagénesis, bien quitada (K.O) por ella), y la secuencia del oligonucleótido de 5' a 3'. Cada cebador se empleó con su pareja complementaria. Los nucleótidos sustituidos aparecen en negrita, los sitios de restricción se muestran subrayados.

\begin{tabular}{|c|c|c|c|}
\hline REGIÓN & MUTACIÓN & $\begin{array}{l}\text { MARCA DE } \\
\text { RESTRICCIÓN }\end{array}$ & OLIGONUCLEÓTIDOS $\left(5^{\prime}-3^{\prime}\right)$ \\
\hline \multirow{2}{*}{ HRA (h4) } & Q204G & $\begin{array}{c}\text { NaeI } \\
\text { gcc/ggc }\end{array}$ & $\begin{array}{l}\text { GCA TCA AAA TTG Ceg gcC AAG TTG } \\
\text { GTG TAG }\end{array}$ \\
\hline & $\mathbf{N 2 1 1 A}$ & $\begin{array}{l}\text { SacI }(\mathrm{K} . \mathrm{O}) \\
\text { gagct } / \mathrm{c}\end{array}$ & $\begin{array}{l}\text { CAA GTT GGT GTA GAa CTC } \mathbf{g g C ~ C T G} \\
\text { TAC CTA ACC }\end{array}$ \\
\hline $\begin{array}{l}\text { Conector } \\
\text { HRB }\end{array}$ & Q454A & $\begin{array}{l}\text { SacII } \\
\mathrm{ccgc} / \mathrm{gg}\end{array}$ & $\begin{array}{l}\text { CAA TAC AAG ATT C cg } \mathbf{c g G} \text { TAA TAA } \\
\text { GAG GC }\end{array}$ \\
\hline \multirow{4}{*}{$\begin{array}{l}\text { N-terminal } \\
\text { HRB }\end{array}$} & L461A & \multirow{4}{*}{$\begin{array}{l}\operatorname{EcoRV}(\mathrm{K} . \mathrm{O}) \\
\text { gat/atc }\end{array}$} & $\begin{array}{l}\text { GTA ATA ATA ACA GGC AAT gcT GAc } \\
\text { ATC TCA ACT GAG C }\end{array}$ \\
\hline & L461F & & $\begin{array}{l}\text { GTA ATA ATA ACA GGC AAT tTT GAc } \\
\underline{\text { ATC TCA ACT GAG }}\end{array}$ \\
\hline & I463A & & $\begin{array}{l}\text { GGC AAT CTT GAT gcG TCA ACT GAG } \\
\text { CTT GGG }\end{array}$ \\
\hline & I463F & & $\begin{array}{l}\text { GGC AAT CTT GAT tTC TCA ACT GAG } \\
\text { CTT GGG }\end{array}$ \\
\hline
\end{tabular}

Durante el presente trabajo, la RT-PCR se utilizó para comprobar las nuevas unidades transcripcionales incorporadas en los genomas de los virus recombinantes rNDV-B1 y rNDV-F3aa. Por cada reacción de retrotranscripción se utilizaron $2 \mu \mathrm{g}$ del RNA total obtenido a partir de células infectadas o 200ng del RNA obtenido a partir de virus purificado según se indica en el apartado anterior, y 50ng del oligonucleótido cebador pNDV/3102+ (ver Tabla 3.4). Ambos se incubaron en un volumen total de $12 \mu 1$ 10 min a $72^{\circ} \mathrm{C}$ para permitir el anillamiento del cebador. A continuación se añadieron $1 \mu 1$ de inhibidor de RNA polimerasa, $4 \mu 1$ de buffer de retrotranscripción, $2 \mu 1$ de DTT $0,1 \mathrm{M}, 1 \mu \mathrm{l}$ de una mezcla de dNTPs $10 \mathrm{mM}$ y $1 \mu 1$ de retrotranscriptasa "Superscript 
II“(Invitrogen). La reacción se llevó a cabo a $42^{\circ} \mathrm{C}$ durante $50 \mathrm{~min}$ y la enzima se inactivó por incubación a $72^{\circ} \mathrm{C}, 10 \mathrm{~min}$

Una vez obtenido el cDNA, se emplearon $5 \mu 1$ de la reacción de retrotranscripción directamente como molde para su amplificación por PCR. El protocolo seguido fue el mismo descrito en el apartado 3.6.9. Como oligonucleótidos cebadores se emplearon pNDV/3102+ y pNDV/3231- (ver Tabla 3.4). La amplificación se comprobó por electroforesis en gel de agarosa y la banda de DNA deseada fue purificada a partir del gel para su secuenciación.

\subsubsection{8.- SECUENCIACIÓN DEL DNA.}

La secuenciación del DNA se llevó a cabo de forma automática utilizando un secuenciador ABI Prism $377^{\mathrm{TM}}$. En primer lugar se realizó una reacción de extensión del DNA que se deseaba secuenciar utilizando un marcaje con fluorescencia incorporada a los diferentes desoxinucleótidos. Cuatro colores diferentes de fluorescencia identificaron a cada uno de los nucleótidos (A, C, G o T). El secuenciador automático realizó la separación electroforética y la detección de los fragmentos de DNA marcados.

Debido al tamaño de los genes y a que sólo son fiables aproximadamente unos 500 pares de bases de lectura del secuenciador, la secuenciaciación de los mismos se hizo de manera fraccionada y solapando las distintas secuencias. Una vez obtenidas todas las secuencias parciales, se analizaron con el programa "Chromas 2.3" y se alinearon de manera apropiada con el programa "CodonCode Aligner".

Los oligonucleótidos se diseñaron, al igual que los que se comentan en el apartado 3.6.8, según las secuencias de la L-endoglina humana, pNDV-B1, pGEM-T y pCAGGS y fueron servidos por la empresa Invitrogen, salvo el denominado OligoRev, que fue amablemente cedido por el Dr. Carmelo Bernabéu del CIB, Madrid. Además de en la secuenciación, muchos de estos cebadores también se emplearon para la selección de clones sobre colonias (apartado 3.6.12) y RT-PCR (apartado 3.6.17). Sus secuencias se detallan en la TFigura 3.4 . 
Tabla 3.4.- Oligonucleótidos empleados en secuenciación, RT-PCR y selección de colonias por PCR

\begin{tabular}{|c|l|c|c|c|}
\hline Nombre & \multicolumn{1}{|c|}{ Oligonucleótido (5' ${\left.\text { - } 3{ }^{\prime}\right)}^{\prime}$} & $\begin{array}{c}\text { Nucleótidos } \\
\text { complementarios } \\
\text { en ORF de } \\
\text { endoglina }\end{array}$ & $\begin{array}{c}\text { Nucleótidos } \\
\text { complementarios } \\
\text { en pNDV }\end{array}$ & Sentido \\
\hline EndoSec/frwrd & CCTTGAGTGGGCAGCTGAG & $438-456$ & - & $5^{\prime}-3^{\prime}$ \\
\hline EndoSec/rev & GCAGCTGTCTAACTGGAGC & $1461-1479$ & - & $3^{\prime}-5^{\prime}$ \\
\hline Int01SecEndo & GTCTTCATGCGCTTGAACATC & $1702-1722$ & - & $5^{\prime}-3^{\prime}$ \\
\hline OligoRev & CAGCTCTGTGGTGTTGAC & $397-414$ & - & $3^{\prime}-5^{\prime}$ \\
\hline pNDV/3102+ & CTGTCCACTCGGCATCACAC & - & $3102-3121$ & $5^{\prime}-3^{\prime}$ \\
\hline pNDV/3231- & CTAGATTAATTACGGTTACGC & - & $3211-3231$ & $3^{\prime}-5^{\prime}$ \\
\hline
\end{tabular}

\begin{tabular}{|c|l|c|c|c|}
\hline Nombre & \multicolumn{1}{|c|}{ Oligonucleótido $\left(5^{\prime}-3^{\prime}\right)$} & $\begin{array}{c}\text { Nucleótidos } \\
\text { complementarios } \\
\text { en ORF de F }\end{array}$ & $\begin{array}{c}\text { Nucleótidos } \\
\text { complementarios } \\
\text { en ORF de HN }\end{array}$ & Sentido \\
\hline F/Sec/frwrd1 & GCATTGCCGCAACCAATG & $470-487$ & - & $5^{\prime}-3^{\prime}$ \\
\hline F/Sec/frwrd2 & CAGGTAACTCTACCTTC & $856-872$ & - & $5^{\prime}-3^{\prime}$ \\
\hline F/Sec/rev & CTCCAGATGTAGTCAC & $316-331$ & - & $3^{\prime}-5^{\prime}$ \\
\hline HN/Sec/frwrd1 & CATTTCAAGAACATC & - & $464-478$ & $5^{\prime}-3^{\prime}$ \\
\hline HN/Sec/frwrd2 & CAACATTATTCGGGGAC & - & $866-882$ & $5^{\prime}-3^{\prime}$ \\
\hline HN/Sec/rev & CTATATAATCTGGGTC & - & $381-396$ & $3^{\prime}-5^{\prime}$ \\
\hline
\end{tabular}

\begin{tabular}{|c|l|c|c|c|}
\hline Nombre & \multicolumn{1}{|c|}{ Oligonucleótido $\left(5^{\prime}-3^{\prime}\right)$} & $\begin{array}{c}\text { Nucleótidos } \\
\text { complementarios } \\
\text { pGEM-T }\end{array}$ & $\begin{array}{c}\text { Nucleótidos } \\
\text { complementarios } \\
\text { en pGAGGs }\end{array}$ & Sentido \\
\hline T7 & TAATACGACTCACTATAGGGGCGA & $2999-6$ & - & $5^{\prime}-3^{\prime}$ \\
\hline SP6 & ATTTAGGTGACACTATAGAATAC & $136-158$ & - & $3^{\prime}-5^{\prime}$ \\
\hline pCAGGs 5 & CCTTCTTCTTTTTCCTACAGC & - & $1651-1671$ & $5^{\prime}-3^{\prime}$ \\
\hline pCAGGs $3^{\prime}$ & CCTTTATTAGCCAGAAGTCAGATGC & - & $1818-1842$ & $3^{\prime}-5^{\prime}$ \\
\hline
\end{tabular}




\section{7.-TÉCNICAS DE RESCATE DEL NDV.}

\subsection{1.- INFECCIÓN CON MVA-T7 DE CÉLULAS EN CULTIVO.}

Los genes codificados en los plásmidos que iban a utilizarse en el rescate se encontraban bajo el control del promotor de la polimerasa del fago T7, de forma que un primer paso debía consistir en la expresión de dicha polimerasa en las células a transfectar. Para ello, placas de $35 \mathrm{~mm}$ con células A549 con una confluencia aproximada del 90\% fueron infectadas con el virus vaccinia Ankara modificado que expresa la polimerasa T7 en células de mamíferos (MVA-T7). Las placas fueron lavadas 2 veces con PBS/BA/PS y tratadas con una solución de infección con MVA-T7 a 1 moi en $100 \mu 1$ de PBS/BA/PS. Se incubaron 1 hora a temperatura ambiente o $30 \mathrm{~min}$ a $37^{\circ} \mathrm{C}$ y posteriormente se retiró la solución y se procedió a la transfección tal y como se describe en el siguiente apartado.

\subsection{2.- TRANSFECCIÓN CON LIPOFECTAMINA.}

Mientras se llevaba a cabo la incubación de la infección con MVA-T7 se preparó el material para la transfección. Por un lado, 1,5 $\mu 1$ de lipofectamina 2000 se incubaron en $250 \mu \mathrm{l}$ de OptiMEM I (por placa) durante 5 minutos. Por otro lado se preparó el DNA, que contenía el plásmido con el genoma recombinante de los virus y también los plásmidos de expresión pTM1-NP, pTM1-P y pTM1-L. Éstos llevan los genes de las proteínas P, NP y L del NDV, también bajo el promotor de T7, y forman el complejo necesario para la replicación del genoma viral. Se añadieron $0,4 \mu \mathrm{g}$ de pTM1-NP, $0,2 \mu \mathrm{g}$ de pTM1-P, $0,2 \mu \mathrm{g}$ de pTM1-L y $1 \mu \mathrm{g}$ del pNDV recombinante en un volumen de $50 \mu 1$ de Optimem I por cada placa. Finalmente, el volumen incubado con lipofectamina se vertió sobre la solución con DNA, y tras una leve agitación se incubó 20min a temperatura ambiente, pasados los cuales se añadieron $300 \mu \mathrm{l}$ de la mezcla a cada una de las placas previamente infectadas con MVA-T7. Además, se añadió 1ml de DMEM$10 \% \mathrm{FBS}$, sin antibióticos, a cada placa, y éstas se incubaron de 6 a 8 horas a $37^{\circ} \mathrm{C}, 5 \%$ $\mathrm{CO}_{2}$, tras las cuales el medio de transfección se sustituyó por 1,5ml de DMEM$10 \% \mathrm{FBS} / \mathrm{PS}$ y se prosiguió con la incubación. 


\subsection{3.- COCULTIVO CON FIBROBLASTOS DE EMBRIONES DE POLLO.}

La linea celular A549 permite la infección con MVA-T7 y la eficiente expresión de los plasmidos transfectantes, pero no facilita la multiplicación de los NDVs originados por éstos. Es por tanto esencial para el rescate de un número adecuado de NDVs un procedimiento que permita su amplificación en células más favorables para su ciclo biológico, como lo son las de su hospedador natural, el pollo. El proceso de cocultivo es el paso más importante de todo el rescate, y debe hacerse de manera que la proporción de fibroblastos embrionarios de pollo (CEF) con respecto a las A549 sea tal que el pequeño número de viriones que salgan de las segundas puedan infectar las primeras. En el caso de los rescates de rNDV-B1, el medio en que se realiza el cocultivo debe disponer de fluido alantoideo procedente de huevos embrionados para que el precursor $\mathrm{F}_{0}$ se active y los viriones sean infectivos. Este requisito no es determinante en el caso del F3aa como se ha explicado previamente (apartado 3.5.7.3). El procedimiento exacto del cocultivo se describe a continuación:

Las células A549, transfectadas según se ha descrito en el apartado anterior y tras 1-2 días de incubación, se cocultivaron con fibroblastos de embriones de pollo, los cuales habían sido obtenidos y crecidos como se describe en el apartado 3.5.3. Se empleó una placa de $100 \mathrm{~mm}$ con CEF totalmente confluentes por cada dos placas de $35 \mathrm{~mm}$ de células transfectadas. A éstas se les aspiró el medio y se lavaron dos veces con PBS; después se añadieron $200 \mu \mathrm{l}$ de tripsina y se incubaron a $37^{\circ} \mathrm{C}$ hasta que las células se desprendieron de la placa. El mismo proceso se llevó a cabo con las placas de CEF, empleando $1 \mathrm{ml}$ de tripsina. En el momento en que las A549 se hubieron despegado, se suspendieron en $1 \mathrm{ml}$ de medio EMEM-10\% FBS/PS con $\mathrm{MgCl}_{2}$ a una concentración final de $30 \mathrm{mM}$ y con $5-10 \%$ de fluido alantoideo. Se pasaron a una placa de $100 \mathrm{ml}$ junto con $3 \mathrm{ml}$ del mismo medio. Por su parte, las CEF, tras haber sido tripsinizadas, se suspendieron en $7 \mathrm{ml}$ del medio antes citado, y $4 \mathrm{ml}$ de la suspensión se pasaron a las placas de $100 \mathrm{~mm}$ con las A549. Éstas se agitaron suavemente para distribuir uniformemente su contenido celular, y se incubaron a $37^{\circ} \mathrm{C}, 5 \% \mathrm{CO}_{2}$ durante 3 a 5 días. 


\subsection{4.- INFECCIÓN DE HUEVOS EMBRIONADOS.}

Entre 3 y 5 días tras el cocultivo, se recogieron $800 \mu l$ del sobrenadante de las placas. Se centrífugaron 30 s para sedimentar las células muertas, y se procedió a infectar huevos embrionados de 8 a 12 días libres de patógenos. Para ello se detectó por transiluminación la cavidad alantoidea del huevo, marcando su posición, sobre la que se realizó una pequeña incisión en la cáscara por la que se procedió a inyectar $500 \mu 1$ del sobrenadante con una jeringuilla estéril (ver Figura 3.8). El orificio se selló con cera fundida o parafina y los huevos se incubaron a $37^{\circ} \mathrm{C}$ durante $2-3$ días, tras los que se extrajo el líquido alantoideo que contenía el virus. Todo el proceso de infección de huevos se llevó a cabo en condiciones estériles.

Figura3.8.- Anatomía de un huevo de pollo de 10 días y procedimiento de infección. El volumen con el virus debe inyectarse en la cavidad alantoidea, cuidando de no dañar al embrión ni a los principales vasos en la zona.

Imagen tomada del documento de la FAO "A basic laboratory manual for the small scale production and testing of I-2 Newcastle Desease Vaccine", disponible en la web http://www.fao.org/documents/ (accedido 03/2009)

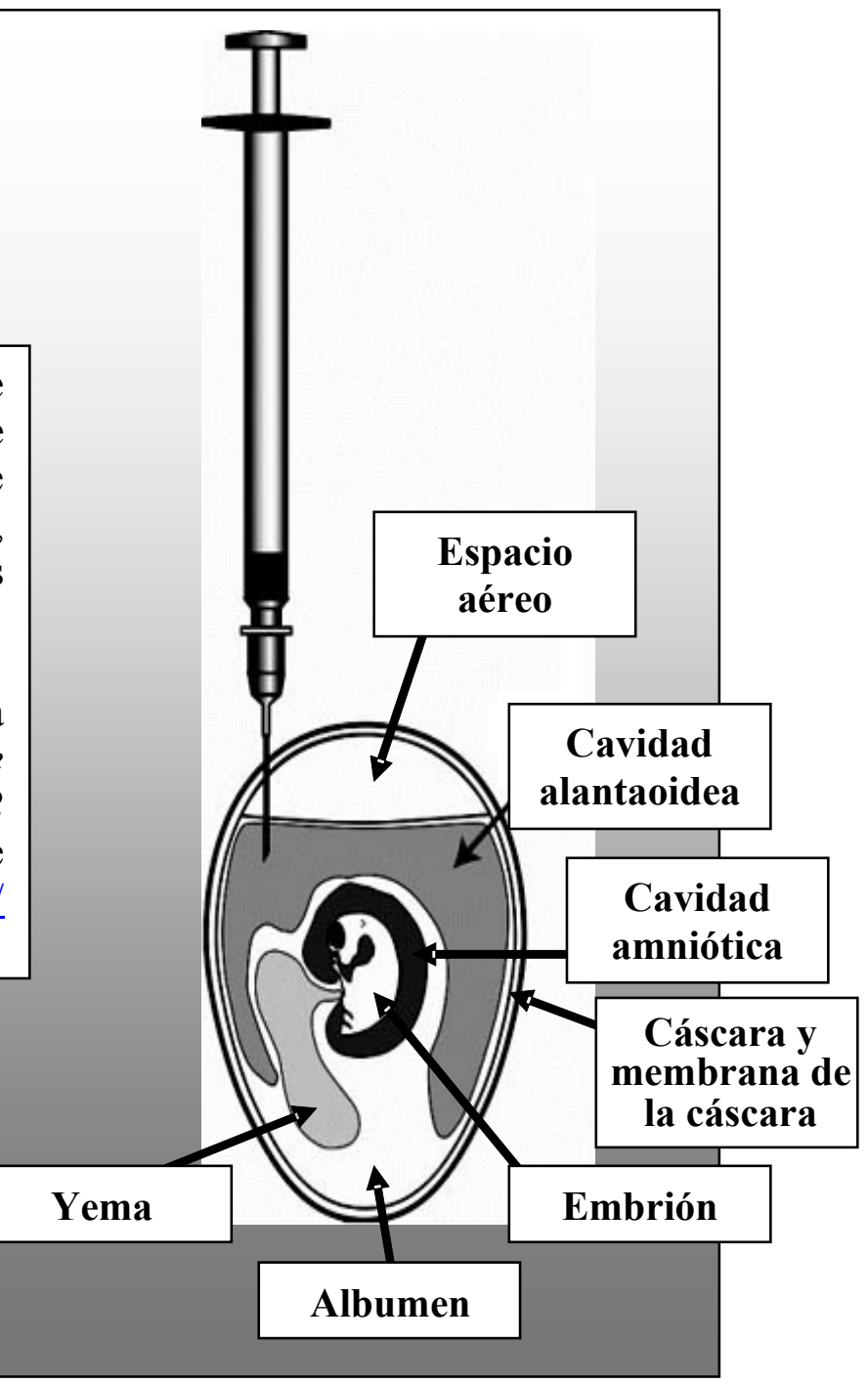




\subsection{5.- EXTRACCIÓN DEL LÍQUIDO ALANTOIDEO.}

Para la extracción del líquido alantoideo de huevos previamente infectados, en primer lugar éstos se incubaron al menos 1-2 horas a $4^{\circ} \mathrm{C}$, para matar al embrión y coagular su sangre. Posteriormente se rompió la cáscara por la región del saco aéreo y se retiraron los fragmentos con unas pinzas, dejando al descubierto la membrana alantoidea. Ésta se rasgó por el lado opuesto al que se podía ver que ocupaba el embrión, para no dañar la yema. Se presionó el embrión suavemente con una espátula hacia la parte inferior del huevo, de forma que el líquido alantoideo ascendió a la parte superior y pudo ser recogido con una pipeta. Todo el proceso se llevó a cabo en condiciones estériles y tras haber rociado los huevos con etanol al 70\%. De cada huevo se recogieron entre $8-12 \mathrm{ml}$ de líquido alantoideo, que fue analizado por medio de un ensayo de hemaglutinación para detectar NDV (apartado 3.9.1). El título del virus presente en el líquido alantoideo se determinó por inmunofluorescencia (apartado 3.8.1).

\subsection{6.- PURIFICACIÓN DE NDV RECOMBINANTE (rNDV).}

Se infectaron 4 huevos embrionados de 8 a 12 días con cada uno de los rNDV que se pretendía purificar según el procedimiento descrito en el apartado 3.7.4. Tras 48 horas de incubación a $37^{\circ} \mathrm{C}$, se extrajo el líquido alantoideo como se ha descrito en el apartado anterior, de forma que se obtuvieron entre 30 y $40 \mathrm{ml}$ de líquido alantoideo de cada virus. Este volumen se centrifugóo $5 \mathrm{~min}$ a $1000 \mathrm{rpm}$ para sedimentar los eritrocitos que pudieran haberse recogido. El sobrenadante se centrífugo $30 \mathrm{~min}$ a $10000 \mathrm{rpm} \mathrm{y} 4^{\circ} \mathrm{C}$ en una ultracentrífuga en el rotor Beckman SW-28. El sobrenadante de esta centrifugación se depositó cuidadosamente sobre solución amortiguadora NTE $(0,5 \mathrm{M}$ $\mathrm{NaCl}, 10 \mathrm{mM}$ Tris-HCl, 1mM EDTA, pH 8.0) con sacarosa al 30\%, en tubos del rotor $\mathrm{SW}-28$. Éstos se centrifugaron $90 \mathrm{~min}$ a $25000 \mathrm{rpm} \mathrm{y} 4^{\circ} \mathrm{C}$. El resultado de este proceso fue un sedimento claro que, tras aspirar el sobrenadante, se resuspendió en $100 \mu 1$ de PBS. Los virus así purificados se guardaron a $-80^{\circ} \mathrm{C}$ hasta su posterior utilización. 


\section{8.- TÉCNICAS DE DETECCIÓN DE PROTEÍNAS.}

\subsection{1.- INMUNOFLUORESCENCIA (IF).}

\subsubsection{1.- Infección de células en cultivo con rNDV para IF.}

Células de distintas líneas se sembraron en placas de 24 pocillos 24 horas antes de la infección para conseguir una monocapa confluente. Pasado ese tiempo se retiró el medio y tras lavar 2 veces con PBS se añadió el medio de infección. Para detectar y titular rNDV mediante IF, tras los rescates se emplearon $200 \mu 1$ de de líquido alantoideo obtenido de los huevos infectados. Con virus ya caracterizados y titulados, la infección se realizó a una m.o.i. de 1 en $200 \mu 1$ de PBS/BA/PS. Como control positivo de infección se empleó NDV recombinante que expresa la proteína roja fluorescente (rNDV-mRFP). Se mantuvieron las células 1 hora a temperatura ambiente con el medio de infección, agitando suavemente las placas cada 20min, y después aquél se sustituyó por $400 \mu 1$ de DMEM-10\%FBS/PS. Las células se incubaron a $37^{\circ} \mathrm{C}$ durante 24 horas hasta que fueron fijadas para la inmunofluorescencia.

\subsubsection{2.- Transfección de células HeLa para IF.}

Células HeLa en placas de 24 pocillos, a un 80-90\% de confluencia, fueron transfectadas empleando Lipofectamina (Invitrogen). La transfección se llevó a cabo según el protocolo mencionado anteriormente (3.7.2), usando $2 \mu \mathrm{g}$ de DNA y $2 \mu \mathrm{l}$ de Lipofectamina por pocillo. El medio de transfección sin antibióticos fue sustituido por medio completo a las 6 h postransfeccción. El plásmido pCAGGs-mRFP, que expresa la proteína monomérica roja fluorescente, fue empleado como control de la eficiencia del proceso. Transcurridas $24 \mathrm{~h}$ postransfección las células fueron fijadas y marcadas como se indica a continuación.

\subsubsection{3.- Fijación de las células e incubación con anticuerpos.}

Se aspiró el medio de los pocillos y éstos fueron lavados 3 veces con PBS. Se fijaron con paraformaldehído al 2,5\% en PBS durante 30min a temperatura ambiente y, 
tras 3 lavados con PBS, se bloqueó con BSA al 1\% en PBS durante 30min. A continuación, se incubaron las células con la dilución adecuada de anticuerpo primario (Tabla 3.1) en PBS/1\%BSA durante 45min a temperatura ambiente, se lavaron 3 veces con PBS y se les añadió el correspondiente anticuerpo secundario marcado con fluoróforo, a una concentración final de $5 \mathrm{mg} / \mathrm{ml}$ (dilución 1:400 de las soluciones comerciales) en PBS/1\%BSA. Se incubaron las células durante $30 \mathrm{~min}$ a temperatura ambiente y en oscuridad. Finalmente, se lavaron los pocillos 5 veces con PBS y se dejaron en agua ultrapura para ser observados al microscopio de fluorescencia Olimpus IX51. Las imágenes se obtuvieron con la cámara digital Olympus DP170, y se procesaron con el programa “Adobe Photoshop".

\subsubsection{4: Titulación del NDV.}

El título de los NDV empleados en este trabajo se determinó mediante inmunofluorescencia sobre células en monocapa confluente sembradas en placas de 24 pocillos. Las células fueron infectadas con diluciones crecientes de la muestra de título desconocido y procesadas para inmunofluorescencia. El número total de células por pocillo se calculó contando las células de pocillos replicados. Se asignó una m.o.i. de 1 a la concentración de virus más baja que determinaba la infección de todas las células del pocillo (todas las células marcadas por IF).

\subsection{2.- OBTENCIÓN DE EXTRACTOS PROTEICOS DE CÉLULAS INFECTADAS.}

Células en monocapa confluente en placas de $100 \mathrm{~mm}$ o de 6 pocillos se infectaron con NDV como se describe en el apartado 3.8.1.1. El virus previamente fue titulado por inmunofluorescencia y la infección se llevó a cabo a una m.o.i. determinada según el experimento. Las células infectadas se mantuvieron en medio completo durante un periodo de tiempo variable dependiendo de lo que se quisiera analizar. Posteriormente se aspiró el medio y las células se recogieron en $1 \mathrm{ml}$ de PBS con ayuda de un rascador. Las células se sedimentaron centrifugando 10min a $2000 \mathrm{rpm}$, y el sedimento se resuspendió en $100 \mu \mathrm{l}$ de solución de lisis (Tris- $\mathrm{HCl} 10 \mathrm{mM} \mathrm{pH} \mathrm{7.6,} \mathrm{NaCl}$ 140mM, EDTA 5mM, Triton X100 1\% y desoxicolato 1\%: suplementado con una combinación de inhibidores de proteasas: pepstatina $1 \mu \mathrm{g} / \mathrm{ml}$, leupeptina $1 \mu \mathrm{g} / \mathrm{ml}$, 
aprotinina $1 \mu \mathrm{g} / \mathrm{ml}$ y PMSF $1 \mathrm{mM}$ ). Tras 10 minutos en hielo, se centrifugó el lisado resultante en una centrífuga de mesa a $13000 \mathrm{rpm}$ 5min para eliminar los restos celulares. El sobrenadante que contenía el extracto proteico se guardó a $-20^{\circ} \mathrm{C}$ hasta su posterior utilización.

En los casos en los que se quiso analizar el sobrenadante del cultivo celular se recogieron $500 \mu 1$ del mismo, a los que se añadió el mismo cóctel de inhibidores de proteasas mencionado anteriormente. Se centrifugó el volumen obtenido en una microcentrífuga a máxima velocidad durante $10 \mathrm{~min}$ y el sobrenadante se guardó a $-20^{\circ} \mathrm{C}$ hasta su utilización.

\subsection{3.- VALORACIÓN DE PROTEÍNAS TOTALES.}

Para determinar la cantidad de proteínas totales que contenían las distintas muestras se empleó el método descrito por Markwell et al. (1978), que es una modificación del desarrollado anteriormente por Lowry et al. (1951) para la cuantificación de proteínas de membrana y lipoproteínas.

Este método colorimétrico se basa en la capacidad de las proteínas para formar complejos de coordinación con el cobre, de forma que el compuesto formado por las proteínas, el sulfato de cobre y el reactivo de Folin-Cicalteu tiene un color azul que tiñe la solución con una intensidad proporcional a la cantidad de proteínas existente en la muestra.

Para el ensayo se utilizaron como patrón concentraciones conocidas de BSA. Se leyó la absorbancia en un espectrofotómetro a una longitud de onda de 660nm.

\subsection{4.- ELECTROFORESIS EN GEL DE POLIACRILAMIDA EN PRESENCIA DE SDS (SDS-PAGE).}

El volumen de muestra que contenía la cantidad deseada de proteínas se diluyó en la misma solución amortiguadora en que se encontraba, y se añadió el volumen preciso de solución amortiguadora de carga (4X Tris-HCl $125 \mathrm{mM}$, SDS 2\%, glicerol $10 \%, \beta$-mercaptoetanol $2 \%$ y azul de bromofenol en cantidad suficiente para obtener una solución coloreada; cuando el objetivo fue la detección de la endoglina en su forma dimérica, no reducida, de $180 \mathrm{KDa}$ no se añadió el agente reductor $\beta$-mercaptoetanol). Las muestras fueron incubadas a $100^{\circ} \mathrm{C}$ durante 3 min antes de ser cargadas en los 
pocillos del gel. La electroforesis se realizó según el procedimiento SDS-PAGE (de Sodium Dodecyl Sulphate-PolyAcrilamide Gel Electrophoresis), basado en la presencia del detergente SDS, con carga negativa, el cual se une a las regiones hidrofóbicas de las proteínas, desplegando las cadenas polipeptídicas, liberándolas de otros componentes y aportándolas una carga neta negativa que permite que migren hacia el ánodo al aplicar un voltaje. Como matriz inerte sobre la que desarrollar la electroforesis se emplearon geles de poliacrilamida con dos secciones, una superior o gel de carga al $4 \%$ y una inferior o gel separador al 8\%. Estos porcentajes, determinantes del tamaño de poro de la matriz y por consiguiente de su capacidad de resolución, fueron adecuados para la separación de las proteínas en todos los geles del presente trabajo excepto en las electroforesis de viriones del NDV purificados, en las que se utilizaron geles en gradiente 5\%-20\%. Para la polimerización de los geles se añadió TEMED $\left(N, N, N^{\prime}, N^{\prime},-\right.$ tetrametil-etilendiamina) y APS (persulfato amónico). Las electroforesis se realizaron aplicando un voltaje constante de $130 \mathrm{~V}$ en solución amortiguadora Tris $25 \mathrm{mM}$, glicina $192 \mathrm{mM}$, SDS 0,1\%

\subsection{5.- TINCIÓN DE GELES DE POLIACRILAMIDA CON AZUL DE COOMASSIE}

En aquellos casos en los que se quiso visualizar las bandas de proteínas tras la electroforesis, se tiñeron los geles con azul brillante de Coomassie R250, originalmente un colorante textil. La solución de tinción se preparó con $0,25 \mathrm{~g}$ de azul de Coomassie en $90 \mathrm{ml}$ de metanol: $\mathrm{H}_{2} 0(1: 1 \mathrm{v} / \mathrm{v})$ y $10 \mathrm{ml}$ de ácido acético glacial, y fue filtrada previa su utilización. Para la tinción, los geles se incubaron en placas Petri de cristal con un volumen adecuado de solución de tinción durante al menos $4 \mathrm{~h}$, en agitación suave y a temperatura ambiente. Transcurrido ese tiempo se destiñeron en la misma solución metanol: $\mathrm{H}_{2} 0$ :ácido acético en la que se había preparado la tinción. Este proceso se llevó a cabo con cambios regulares de solución durante varias horas hasta que las bandas proteicas, teñidas de azul oscuro, contrastaron con el fondo decolorado del gel. 


\subsection{6.- TRANSFERENCIA ELECTROFORÉTICA DE PROTEÍNAS (WESTERN BLOT)}

Desde el gel de poliacrilamida, las proteínas se transfirieron electroforéticamente a una membrana de PVDF (difluoruro de polivinilideno) empleando una solución de transferencia de Tris $20 \mathrm{mM}$, glicina $190 \mathrm{mM}, \mathrm{pH}$ 8.3. La electroforesis se desarrolló a una intensidad constante de $400 \mathrm{~mA}, 1$ hora a $4^{\circ} \mathrm{C}$, tras lo cual la membrana se lavó en una solución de Tris 20mM, TWEEN-20 0,1\%, NaCl 150mM, pH 7.5, con agitación durante unos minutos para retirar los restos de sales. A continuación, se incubó la membrana con una solución de bloqueo igual a la de lavado pero con un 3\% de BSA, en agitación y durante 1 hora a temperatura ambiente o durante toda la noche a $4^{\circ} \mathrm{C}$.

Tras el bloqueo, se procedió a la incubación con los anticuerpos diluidos en la misma solución de bloqueo (ver Tabla 3.1). Esta incubación tuvo lugar en agitación 90 min a temperatura ambiente o bien toda la noche a $4^{\circ} \mathrm{C}$. Tras el tratamiento con el anticuerpo primario, se lavó la membrana $7 \mathrm{~min}$ con la solución de lavado antes descrita, 3 veces, y a continuación se incubó 30min con la dilución correspondiente de anticuerpo secundario marcado con peroxidasa de rábano (HRP), en agitación y a temperatura ambiente. Posteriormente se volvió a lavar 3 veces la membrana, 7 min en solución de lavado, y se procedió a su revelado.

Para la detección de las proteínas inmovilizadas en la membrana y marcadas con el complejo anticuerpo primario-anticuerpo secundario-HRP se utilizó la quimioluminiscencia provocada por la oxidación del luminol (5-amino-2,3-dihidro-1,4ftalatozinediona) por la HRP en presencia de peróxido de hidrógeno. Para ello se prepararon dos soluciones:

Solución 1: 500ml Tris-HCl 0,1M pH 9.3.

Solución 2: 500ml Tris-HCl 0.1M pH 9.3; 390mg de luminol; 475mg de 4iodofenol

Se prepararon $10 \mathrm{ml}$ por membrana de una mezcla 1:1 de ambas soluciones, y se añadieron $0,5 \mu \mathrm{l}$ de $\mathrm{H}_{2} \mathrm{O}_{2}$ al $30 \%$ por cada $10 \mathrm{ml}$ de mezcla. Con ella se incubaron las membranas $1 \mathrm{~min}$ a temperatura ambiente, tras lo cual se retiró totalmente la solución de revelado. La membrana se incluyó en película transparente y se introdujo en la cassette de revelado, donde se produciría la exposición de una película fotográfica a determinados periodos de tiempo. El revelado se llevó a cabo en una máquina de revelado convencional. 


\subsection{7.- CUANTIFICACIÓN DE LA EXPRESIÓN DE LA PROTEÍNA F EN LA SUPERFICIE CELULAR MEDIANTE CITOMETRÍA DE FLUJO.}

Se partió de células HeLa procedentes de dos placas de $35 \mathrm{~mm}$ transfectadas con $2 \mu \mathrm{g}$ de plásmido de la proteína $\mathrm{F} 24 \mathrm{~h}$ antes del experimento. Las células fueron recogidas con ayuda de un rascador, lavadas con PBS y sedimentadas por centrifugación a $2000 \mathrm{rpm}$ durante $5 \mathrm{~min}$. Una vez resuspendidas en $200 \mu 1$ de PBS se les añadió el anticuerpo primario, bien el anticuerpo monoclonal 2A6 anti-F o el suero policlonal anti-NDV, y se incubaron durante $15 \mathrm{~min}$ a temperatura ambiente. Tras eliminar el exceso de anticuerpo por centrifugación (5min, $2000 \mathrm{rpm}$ ), las células fueron incubadas con los anticuerpos secundarios correspondientes, anti-ratón o anti conejo, conjugados con el fluoróforo Alexa Fluor 488 durante $15 \mathrm{~min}$ a temperatura ambiente y

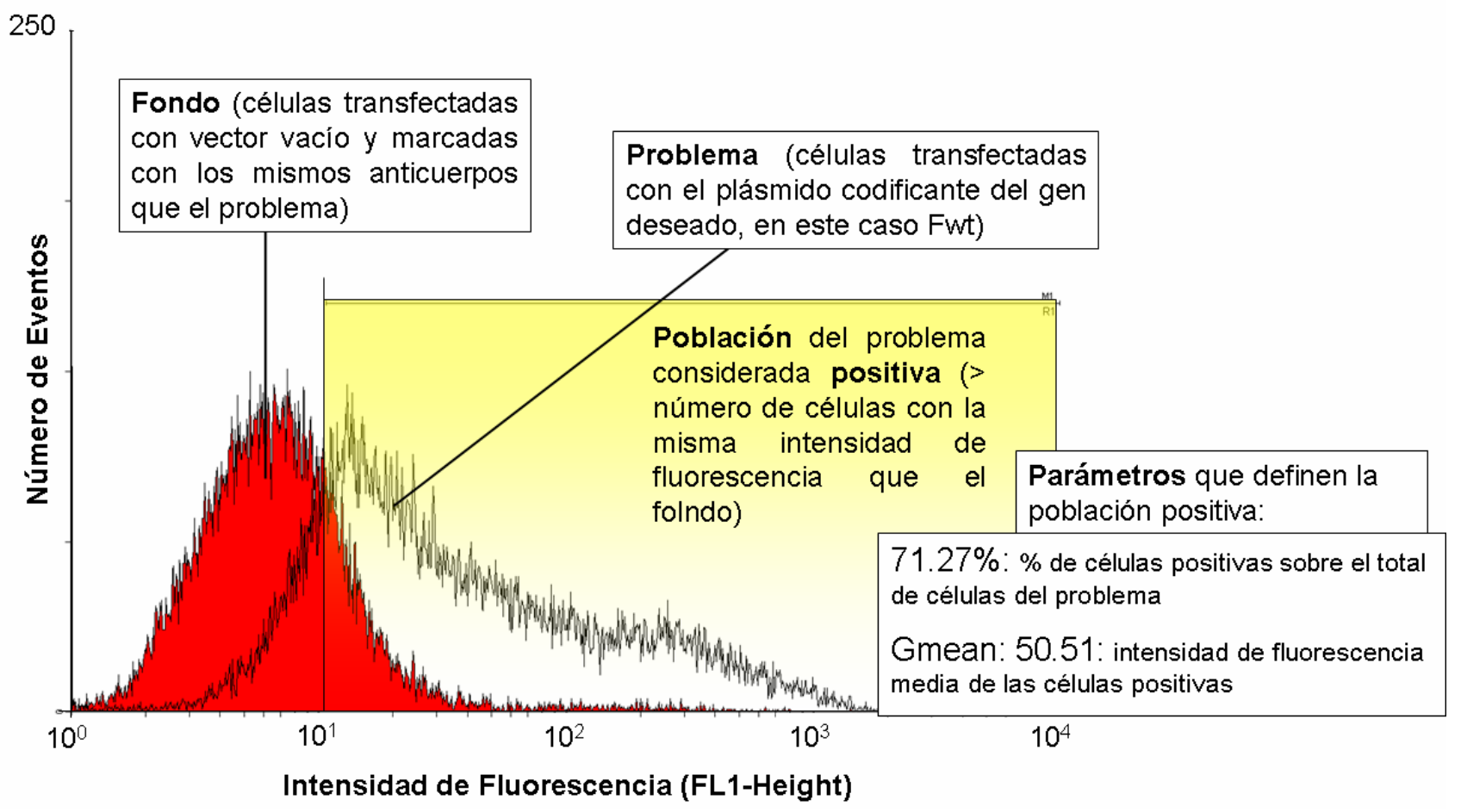

Figura3.9.- Interpretación de los resultados de un estudio de citometría de flujo. En cada experimento se compararon los histogramas obtenidos con el control de células no transfectadas con los histogramas de las distintas formas de la proteína $\mathrm{F}$. El porcentaje y la intensidad media de fluorescencia media (Gmean) se obtuvieron tal y como se indica en la Figura. Los datos finales de expresión se obtuvieron como (\%xGmean)/100 y se refirieron al valor obtenido con Fwt, considerado el 100\%. 
en oscuridad. A continuación se añadió la solución fijadora "FACS lysing solution" durante 10 minutos, transcurridos los cuales se centrifugó durante 5 min a $2000 \mathrm{rpm}$ para eliminar el sobrenadante, se lavó con PBS y finalmente se resuspendió la muestra en $200 \mu 1$ de PBS para su posterior análisis en el citómetro FACScalibur. Por cada experimento se adquirieron 300000 células. Los resultados se analizaron con el programa WinMDI 2.9. Los parámetros que se tuvieron en consideración para interpretar los resultados fueron el $\%$ de células positivas y la intensidad de fluorescencia media (Gmean) de las mismas, y en cada cada exprimento se refirieron a los resultados con Fwt, considerados el 100\%. La Figura3.9 indica la manera en que se calcularon dichos parámetros.

\section{9.- OTRAS TÉCNICAS}

\subsection{1.- ENSAYO DE HEMAGLUTINACIÓN.}

La hemaglutinación de eritrocitos por partículas víricas es visible macroscópicamente y puede emplearse para la detección de éstas en el líquido alantoideo recogido en el apartado anterior. En el caso del NDV, este ensayo permite la detección de un mínimo de $10^{6}$ unidades formadoras de placa (pfu), pero no discrimina entre viriones infectivos y partículas víricas parcialmente degradadas.

Se partió de $10 \mathrm{ml}$ de eritrocitos de pavo en solución de Alsever $(75 \mathrm{mM} \mathrm{NaCl}$, $25 \mathrm{mM}$ citrato sódico, $110 \mathrm{mM}$ glucosa, $\mathrm{pH}$ 6.1). Un volumen de $5 \mathrm{ml}$ de esta suspensión se lavó con $45 \mathrm{ml}$ de PBS y los eritrocitos se recogieron por centrifugación $5 \mathrm{~min}$ 1000rpm a temperatura ambiente. A partir del sedimento se hizo una dilución 1:100 con PBS, que fue la que se empleó para el ensayo de hemaglutinación.

El ensayo se llevó a cabo en placas de 96 pocillos de fondo cónico de la siguiente manera: Se añadieron $50 \mu \mathrm{l}$ de PBS en todos los pocillos menos en los primeros de cada serie; en éstos se depositaron $80 \mu$ de cada una de las muestras de líquido alantoideo extraídas, y a partir del mismo se realizaron diluciones seriadas en base 2 , de forma que se desecharon $50 \mu 1$ de los últimos pocillos de cada serie. Después se añadieron $50 \mu 1$ de eritrocitos de pavo en PBS a cada pocillo, y tras mezclar la placa se incubó 30-45min en hielo para dejar que las células se asentasen, tras lo que se 
procedió a su lectura. En los pocillos donde no se produjo hemaglutinación, los eritrocitos sedimentan en el fondo del pocillo, y se pueden desplazar fácilmente poniendo la placa en posición vertical. En los pocillos donde partículas víricas producen hemaglutinación, ésta bien impidió la sedimentación o bien el sedimento quedó inamovible en el fondo del pocillo. La Figura3.8 esquematiza cómo interpretar los resultados del ensayo de hemaglutinación.
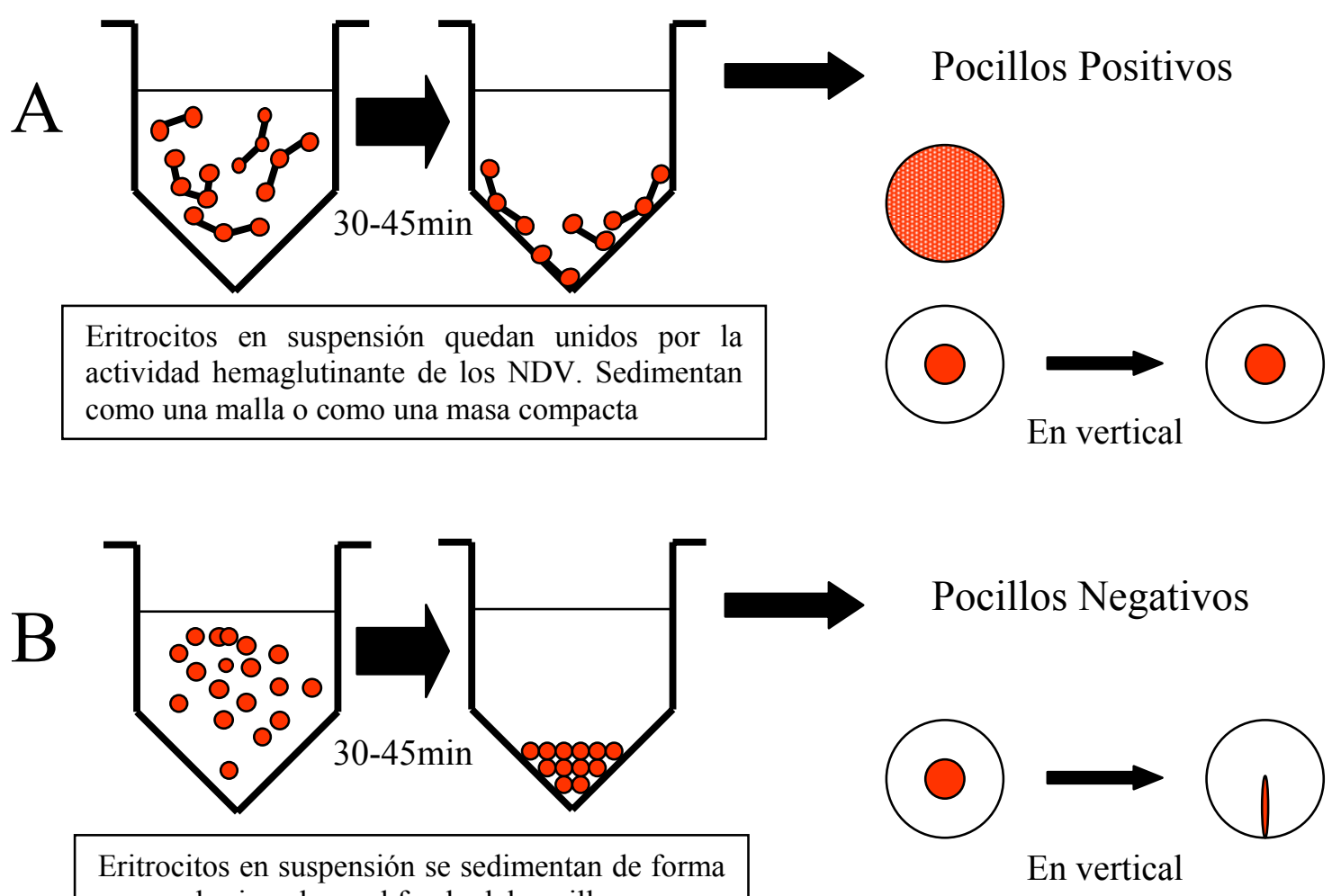

Eritrocitos en suspensión se sedimentan de forma poco cohesionada en el fondo del pocillo

En vertical

Figura3.10.- Fundamento e interpretación de un ensayo de hemaglutinación. A.- Ensayo positivo. B.- Ensayo negativo.

\subsection{2.- VALORACIÓN DE LA ACTIVIDAD FUSOGÉNICA MEDIANTE EL MÉTODO DE LOS SINCITIOS.}

Este método se basa en la capacidad de las glicoproteínas de ciertos virus para promover la fusión célula-célula al ser expresadas en la superficie de las mismas. De esta forma se generan células gigantes multinucleadas denominadas sincitios, de fácil identificación. La visualización de estos sincitios se utilizó como valoración cualitativa de la distinta capacidad fusogénica de los mutantes de la proteína $\mathrm{F}$. 
Los experimenos se llevaron a cabo sobre monocapas de células HeLa o BHK21 sembradas en placas de 12 pocillos. Las células se cotransfectaron con los plásmidos expresando las distintos genes de F así como con HN, HA o el vector pCAGGs vacío, usándose un total de $2 \mu \mathrm{g}$ de DNA por pocillo. La transfección se realizó con Lipofectamina y en las mismas condiciones descritas en el apartado 3.7.2. Pasadas 24 horas postransfección la proteína $\mathrm{F}$ fue activada mediante la adición de $\mathrm{N}$-acetiltripsina $(5 \mu \mathrm{g} / \mathrm{ml})$ durante $10 \mathrm{~min}$, permitiendo la conversión proteolítica del precursor $F_{0}$ en sus subunidades activas $F_{1}$ y $F_{2}$. Posteriormente se lavaron las células con inhibidor de acetiltripsina $(7,5 \mu \mathrm{g} / \mathrm{ml})$, se añadió medio fresco y se incubaron las células de nuevo durante tiempos variables en función del experimento. Finalmente, las células se fijaron con formaldehido al 10\% y se tiñeron con el colorante cristal violeta al 0,1\% en metanol al $20 \%$ para su visualización y posterior fotografía en un microscopio invertido.

\subsection{3.- ENSAYOS DE FUSIÓN POR TRANSFERENCIA DE SONDA}

Esta técnica se desarrolló para la cuantificación de los niveles de fusión inducidos por los distintos mutantes, así como para analizar su dependencia de la temperatura y de la presencia de HN. Para ello, se marcaron eritrocitos humanos con dos tipos de sonda: el cloruro de octadecil rodamina (R18), una molécula lipofílica de color rojo brillante que se inserta en las membranas biológicas, y la calceína, una sonda soluble de color verde. Los eritrocitos así marcados pueden unirse a células que expresen una proteína con actividad hemaglutinante, como HN del NDV o HA del virus de la gripe. Si además esas células también expresan la proteína de fusión $\mathrm{F}$, las membranas marcadas de los eritrocitos se fusionan con las de la célula, marcándolas de rojo. Si la fusión es completa y el contenido de los eritrocitos se libera al citosol celular éste también aparecerá marcado de verde. Sin embargo, si sólo se produce hemifusión las células estarán marcadas en rojo en la membrana pero no en verde en el citosol. De esta manera, empleando el tipo silvestre de proteína F sólo aparecerán células marcadas si éstas expresan también su HN homotípica, necesaria para la promoción como se ha comentado anteriormente (apartado 1.3.4). La Figura3.11 esquematiza los posibles resultados del ensayo. 


\subsubsection{1.- Marcaje de eritrocitos humanos con calceína y R18.}

La sangre empleada para la obtención de los eritrocitos durante todos los ensayos del presente trabajo fue amablemente suministrada por donantes voluntarios del Centro de Hemoterapia y Hemodonación de Castilla y León a través de su sede del Hospital Virgen de la Vega de Salamanca. Para el marcaje de los eritrocitos se partió de $4 \mathrm{ml}$ de sangre con heparina, que se añadieron a 30ml de PBS y se centrifugaron a $200 \mathrm{x}$ $g$ durante $15 \mathrm{~min}$ a $4^{\circ} \mathrm{C}$. Este paso de lavado se repitió una vez más y posteriormente los eritrocitos se sedimentaron centrifugando a $700 \mathrm{x} g$ durante $15 \mathrm{~min}$. Partiendo de que en la sangre humana los eritrocitos están en torno al 50\% de hematocrito y asumiendo una cierta pérdida en cada paso de lavado, el sedimento resultante se resuspendió en $14 \mathrm{ml}$ de PBS para aproximadamente obtener un $10 \%$ de hematocrito final.

Para marcar los eritrocitos con la sonda soluble calceína, $2 \mathrm{ml}$ de eritrocitos al $10 \%$ de hematocrito se incubaron con $200 \mu \mathrm{g}$ de calceína disueltos primero en $20 \mu 1$ de DMSO y posteriormente en $80 \mu 1$ de PBS. Dicha incubación se llevó a cabo durante $1 \mathrm{~h}$ a $37^{\circ} \mathrm{C}$, en oscuridad y con agitaciones periódicas. Después los eritrocitos marcados se lavaron 2 veces con $1 \mathrm{ml}$ de PBS para eliminar el exceso de sonda y se resuspendieron en $4 \mathrm{ml}$ de PBS ( $5 \%$ de hematocrito final), tras lo que se procedió a su marcaje con la sonda lipofílica R18, añadiendo $50 \mu 1$ de la misma $(2 \mathrm{mg} / \mathrm{ml}$ en etanol). La mezcla se incubó 30min en oscuridad a temperatura ambiente con agitaciones periódicas. Después, los eritrocitos se lavaron y sedimentaron en 50ml de PBS y se resuspendieron en $50 \mathrm{ml}$ de medio DMEM completo para que la sonda no incorporada se fuera adsorbida por el suero. Tras una incubación de $30 \mathrm{~min}$ en oscuridad, los eritrocitos ya doblemente marcados se lavaron 5 veces con $50 \mathrm{ml}$ de PBS y finalmente se resuspendieron en $2 \mathrm{ml}$ de PBS (10\% hematocrito final) y la preparación se guardó a $4^{\circ} \mathrm{C}$ durante periodos de tiempo no superiores a una semana. La eficacia del marcaje se comprobó observando una muestra al microscopio de fluorescencia.

\subsubsection{2.- Procedimiento experimental y cuantificación de los resultados.}

Los experimentos se llevaron a cabo sobre monocapas de células HeLa (células efectoras) en placas de 12 pocillos, que fueron cotransfectadas con los plásmidos expresando las distintos genes de F así como con HN, HA o el vector pCAGGs vacío, usándose un total de $2 \mu \mathrm{g}$ de DNA por pocillo. El plásmido pCAGGs-mRFP fue 
empleado como control de la eficiencia de transfección. Pasadas 24 horas postransfección se activó el precursor $\mathrm{F}_{0}$ mediante la adición de acetil tripsina como se ha descrito anteriormente en el apartado 3.9.2 e inmediatamente se añadieron a cada pocillo $250 \mu 1$ de DMEM completo con los eritrocitos marcados $(0,2 \%$ de hematocrito) y Hoetsch a $10 \mu \mathrm{g} / \mathrm{ml}$ para el marcaje de los núcleos. Esta mezcla de células efectoras/dianas se incubó durante distintos tiempos y a distintas temperaturas en función del experimento. Finalmente, las monocapas se lavaron varias veces con PBS para eliminar los eritrocitos no unidos y se visualizaron al microscopio invertido de fluorescencia. Para la cuantificación de la fusión producida, se fotografiaron aleatoriamente tres campos de cada pocillo en un microsccopio de fluorescencia Olympus X187 (objetivo 10X). El porcentaje de eventos positivos (células marcadas con calceína y/o R18) se calculó en relación al número total de núcleos, considerando como el $100 \%$ en cada experimento el valor obtenido para $\mathrm{Fwt}+\mathrm{HN}$ a $37^{\circ} \mathrm{C}$.

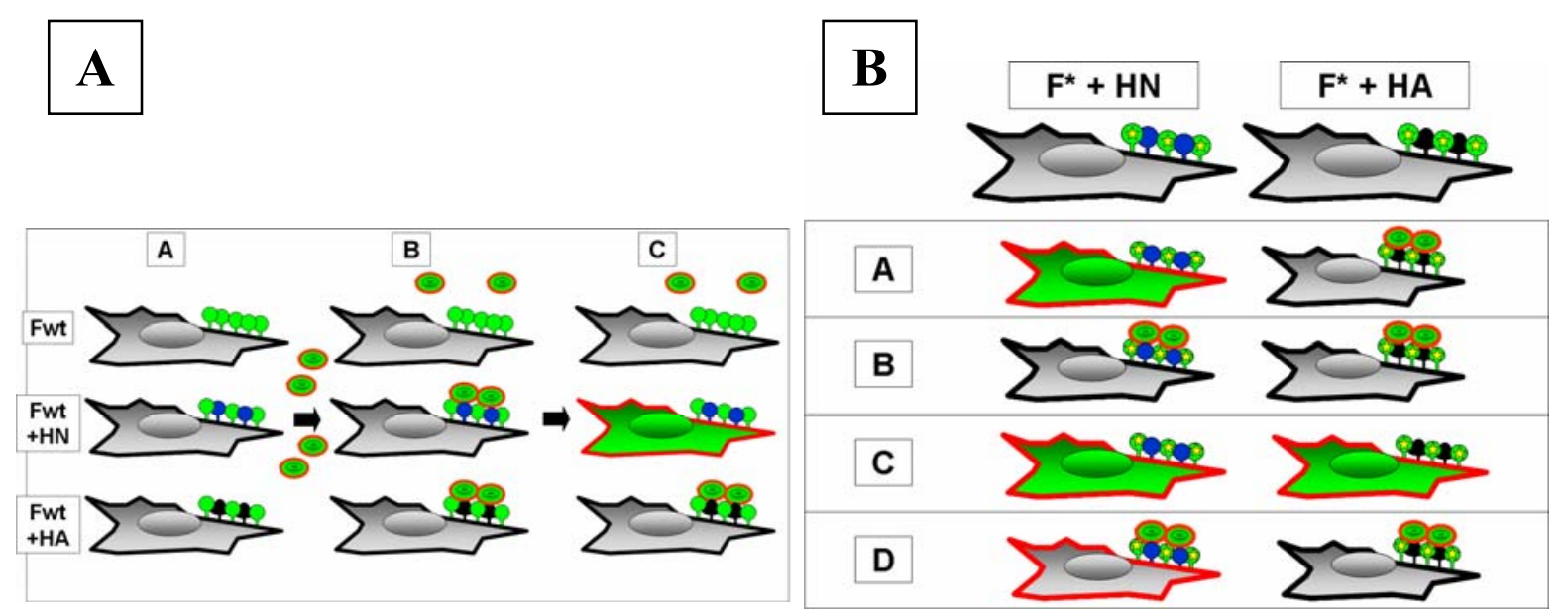

Figura3.11.- Fundamento e interpretación de un ensayo de fusión mediante transferencia de sonda. (A).- Distintas posibilidades en células que expresan el tipo silvestre $\mathrm{F}$ (Fwt). (A): Las células se transfectan con el plásmido codificante para Fwt sólo o junto a HN o HA. (B): Se añaden los eritrocitos marcados con calceína (verde, soluble) y R18 (roja, lipofílica). Sólo en aquellas células que expresen proteínas con actividad hemaglutinante (HN o HA) se adsorberán los eritrocitos. (C): Dado que Fwt precisa de HN para ser funcional, sólo en las células en que ambas se coexpresen se produce la transferencia de sonda desde los eritrocitos fusionados, quedando marcadas las membranas con R18 y el interior celular con calceína. (B).- Posibles resultados de un ensayo de transferencia de sonda con un mutante de $\mathrm{F}$ al coexpresarse con HN o HA. (A) Fenotipo similar a Fwt. Fusión y dependencia de HN. (B) Fenotipo no fusogénico. (C) Fenotipo fusogénico independiente de HN. (D) Fenotipo hemifusogénico: la fusión queda bloqueada en un estadio intermedio y únicamente se produce la mezcla de los componentes lipídicos de las membranas. 



\section{1.- Estudio del NDV como vector de expresión} de L-endoglina humana 


\subsection{1.- CONSTRUCCIÓN DE LOS PLÁSMIDOS pNDV-Endo y pNDV-EExC/F-TMCyt.}

Para la clonación de las secuencias de endoglina y de la quimera endoglinaNDV $\mathrm{F}$ en los plásmidos con el cDNA completo del NDV, tanto pNDV-B1 como pNDV-F3aa, se siguió la siguiente estrategia, cada uno de cuyos pasos será revisado en los siguientes apartados:

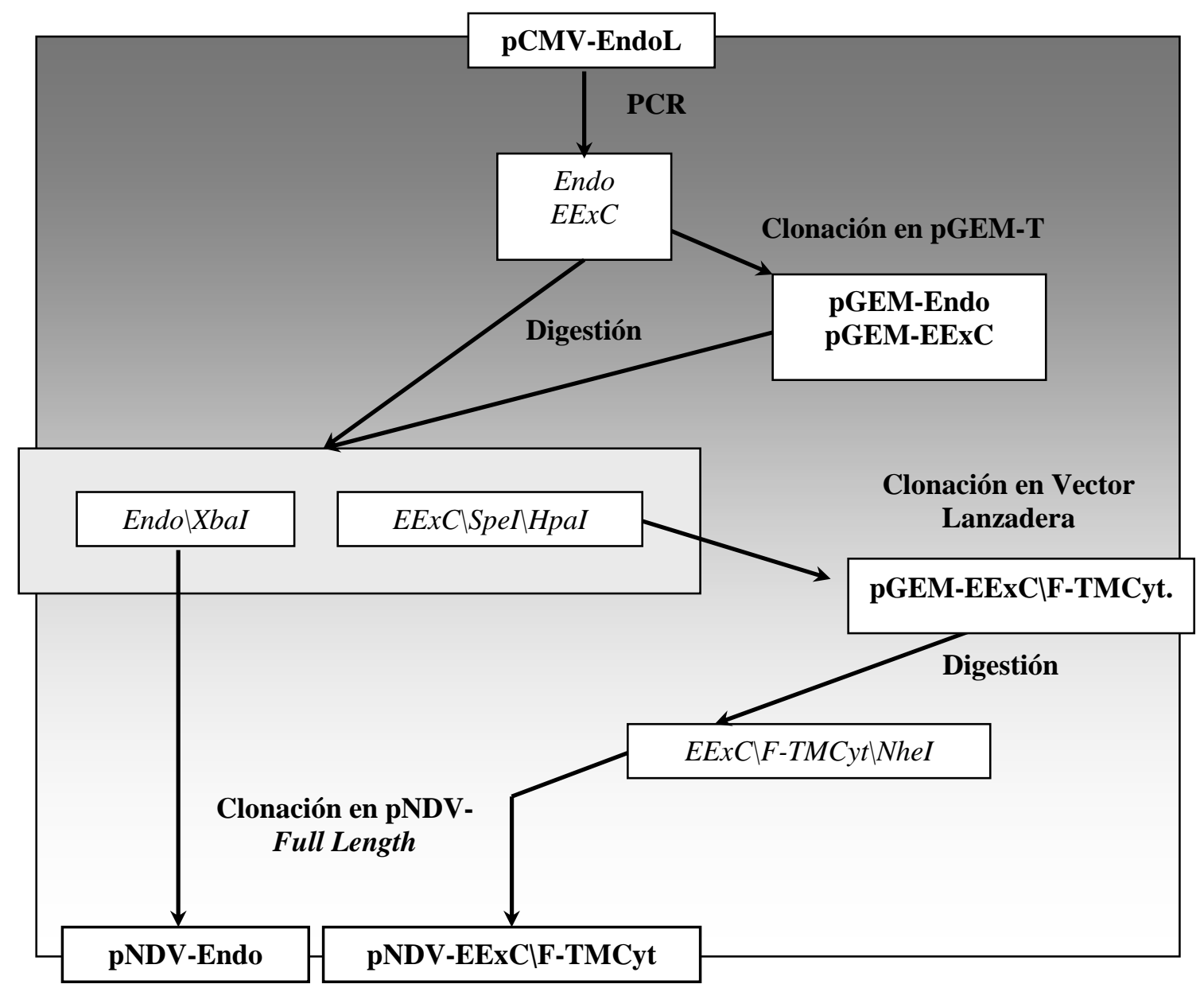

Figura 4.1.- Proceso de construcción de pNDV-Endo y pNDVEExC/F-TMCyt. En cursiva aparecen los nombres de fragmentos lineales de DNA obtenidos por PCR o digestión; en negrita, los plasmidos. 


\subsubsection{1.- Amplificación de las secuencias Endo y EExC por PCR.}

Para la obtención de los insertos que posteriormente serían clonados en los distintos vectores, se partió del plásmido pCMV5-EndoL con la ORF completa de la isoforma L de endoglina humana. Para la amplificación de la ORF completa (fragmento Endo) se emplearon los oligonucleótidos Endo/XbaI/frwrd y Endo/XbaI/rev, y para la amplificación selectiva del dominio extracelular de la proteína (fragmento $E E x C$ ) los oligonucleótidos EExC/SpeI/frwrd y EExC/HpaI/rev (ver apartado 3.6.8.1 y Tabla 3.2). La reacción en cadena de la polimerasa (PCR) se llevó a cabo en ambos casos según el procedimiento descrito en el apartado 3.6.9. Una vez concluida, se comprobó en un gel de agarosa si la amplificación se había producido adecuadamente, visualizando bandas de aproximadamente $2 \mathrm{~Kb}$ en el caso del fragmento Endo y de $1.8 \mathrm{~Kb}$ en el caso de EExC. Tras la comprobación, todo el volumen resultante de las PCR se limpió empleando el kit “QIAquick PCR Purification” como se describe en el apartado 3.6.10.

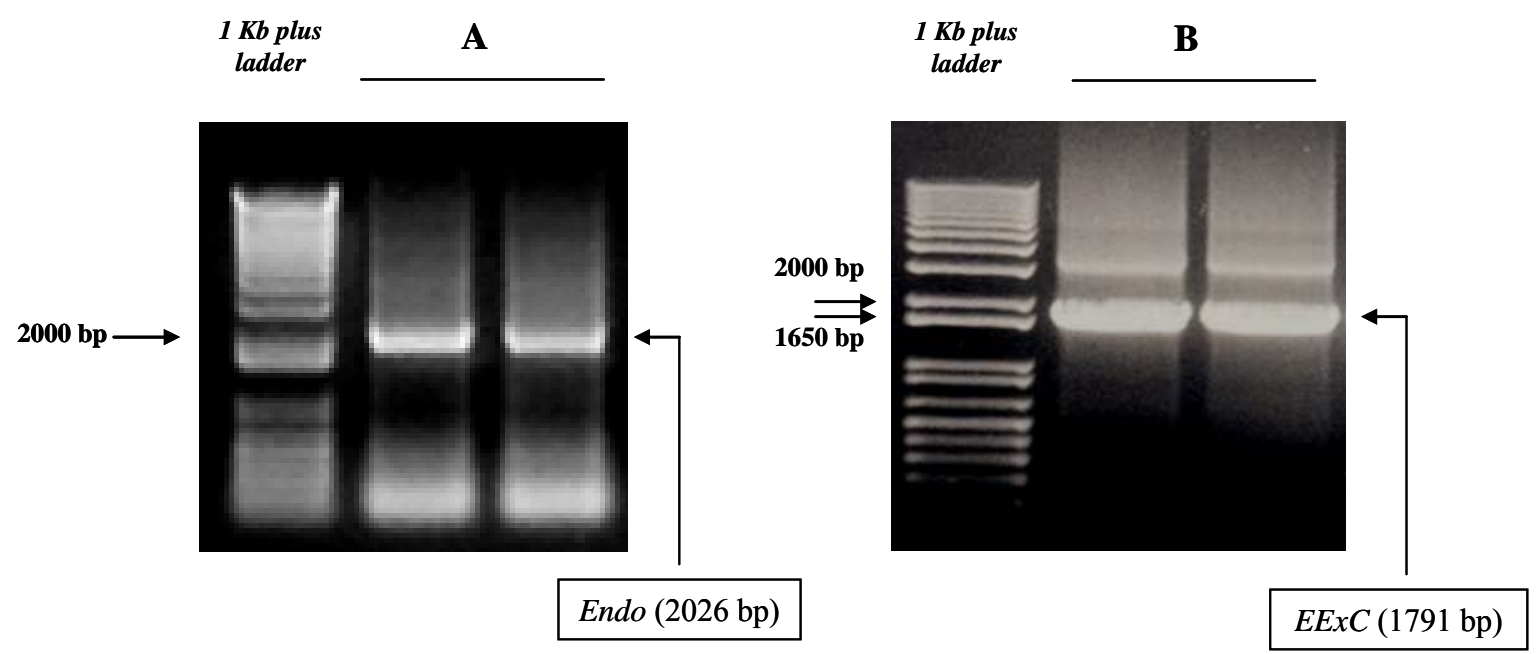

Figura 4.2.- PCR sobre pCMV5-EndoL Electroforesis en geles de agarosa al $0.8 \%$. (A): Fragmento con la ORF completa de endoglina (Endo). (B): Fragmento con la secuencia de su dominio extracelular $(E E x C)$. Apréciese que los tamaños citados son mayores que los que aparecen en la Figura 3.7 de Material y Métodos, ya que en aquel caso se consideró sólo la longitud que iba a incorporarse finalmente a los pNDV; en este caso se considera la extensión de todo el fragmento amplificado. 


\subsubsection{2.- Clonación de Endo Y EExC en pGEM-T.}

Del volumen total de reacción de PCR limpia, la mitad se destinó a ser clonado en el vector pGEM-T (ver apartado 3.5.7.2). Aunque no era el vector definitivo en el que se querían incluir los insertos, la clonación en el mismo tiene varias ventajas; no precisa de digestiones previas, tiene una alta eficiencia, suministra un soporte más adecuado para una posterior digestión de los insertos o para su secuenciación, y permite una masiva amplificación de los fragmentos ya clonados sin tener que recurrir de nuevo a la PCR. La clonación se llevó a cabo como se describe en el apartado 3.6.12, tras lo que se procedió a transformar bacterias competentes con la mezcla de ligación. Se realizó una primera selección según el color de las colonias obtenidas, gracias al sistema de la $\beta$-galactosidasa que posee pGEM, y a continuación se comprobó que las colonias habían sido transformadas con la construcción deseada mediante un análisis por PCR. Se emplearon como cebadores EndoSec/rev y un oligonucleótido para la región del promotor de T7 presente en pGEM (T7, ver Tabla 3.3), produciéndose una banda de aproximadamente 1550 pares de bases en los clones en que Endo o EExC se habían introducido bajo control de dicho promotor (ver Figura 4.3).
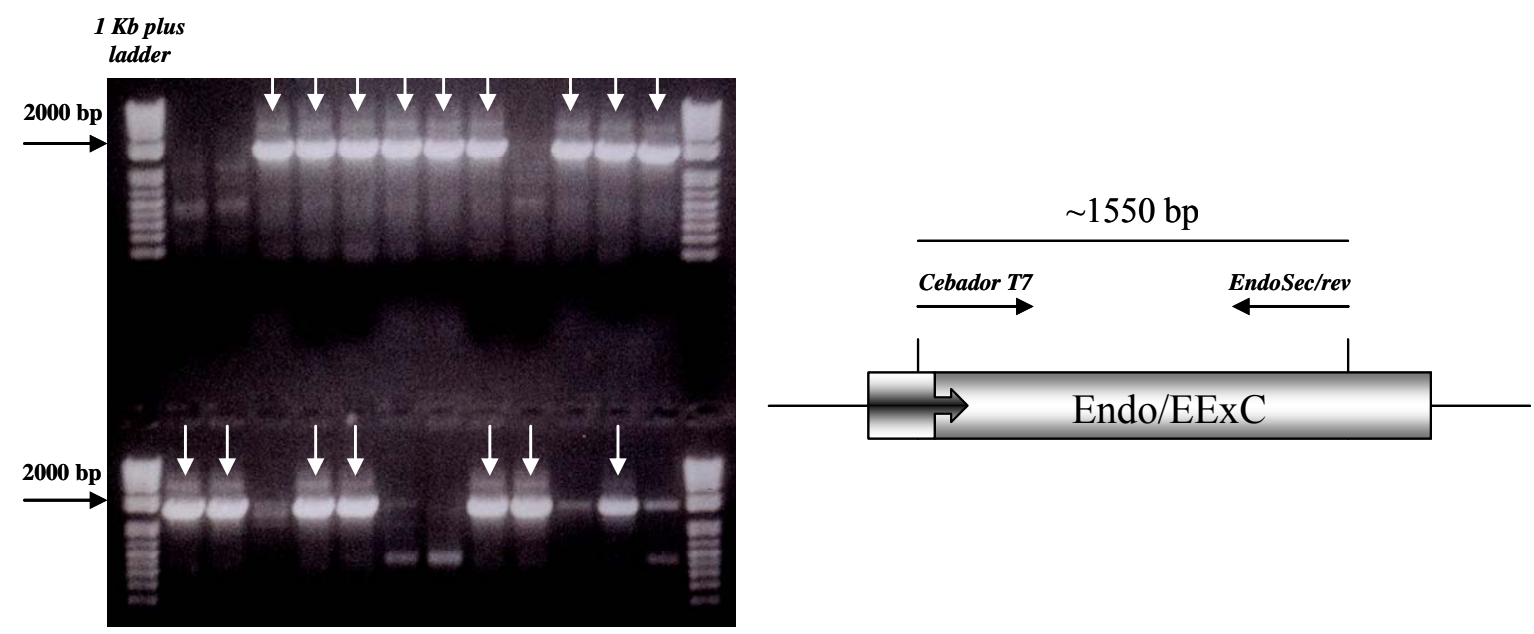

Figura 4.3.- Análisis por PCR sobre colonias con pGEM-EExC. Electroforesis en gel de agarosa al $0.8 \%$ de los productos de PCR Con flechas se indican los clones positivos, en los que se ha producido amplificación según se muestra en la Figura de la dararho 


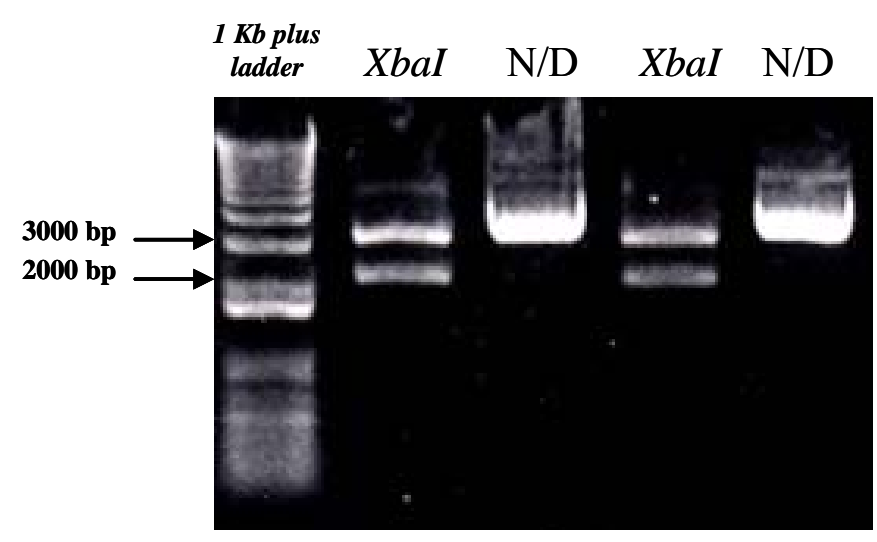

Figura 4.4.- Digestión de pGEM-Endo con XbaI. Electroforesis en gel de agarosa al $0.8 \%$. Se comprueba que el inserto introducido es del tamaño adecuado (aprox. $2 \mathrm{~Kb}$ ) (N/D: no digerido)

Los clones que resultaron positivos en el análisis anterior se amplificaron en cultivo bacteriano (apartado 3.6.1) y se analizaron mediante digestión con la enzima $X b a I$ en el caso de Endo y con SpeI/HpaI en el de EExC, verificándose en cada caso que el fragmento clonado era el indicado (Figura 4.4). Finalmente, de entre todos los positivos se seleccionaron aleatoriamente dos para cada construcción, de los que se obtuvieron grandes cantidades de DNA plasmídico según el procedimiento descrito en el apartado 3.6.1.

\subsubsection{3.- Clonación de EExC en pGEM-NDV-F/TMCyt.}

Tanto el volumen de la PCR para EExC que no se había empleado en el apartado 4.1.1.2 como el vector recién construido pGEM-EExC fueron digeridos con las enzimas SpeI/HpaI. Todo el volumen de la reacción se cargó en un gel de agarosa al $0.8 \%$ del que se purificó la banda de interés de aproximadamente $1.8 \mathrm{~Kb}$. Por otro lado, el vector lanzadera pGEM-NDV-F/TMCyt fue también digerido con SpeI/HpaI para liberar el inserto de HA de gripe para el que originariamente se había diseñado. El vector fue aislado por purificación desde el gel, y después fue convenientemente desfosforilado con fosfatasa alcalina (CIP) (apartado 3.6.6). Una vez se dispuso del vector y el inserto en las condiciones adecuadas, se procedió a la clonación tal y como se describe en el apartado 3.6.11. Las colonias resultantes se emplearon para inocular cultivos bacterianos de los que se extrajo el DNA plasmídico, sobre el que posteriormente se 
llevó a cabo una reacción de digestión con la enzima NheI. Los clones positivos fueron aquellos que poseían el fragmento de unas $2 \mathrm{~Kb}$, correspondiente a la quimera deseada con el dominio extracelular de endoglina y los transmembrana y citoplasmáticos de la proteína F de NDV (Figura 4.5). Cabe destacar que la clonación tuvo aproximadamente el mismo rendimiento partiendo del producto de PCR directamente digerido que del inserto procedente del vector pGEM.

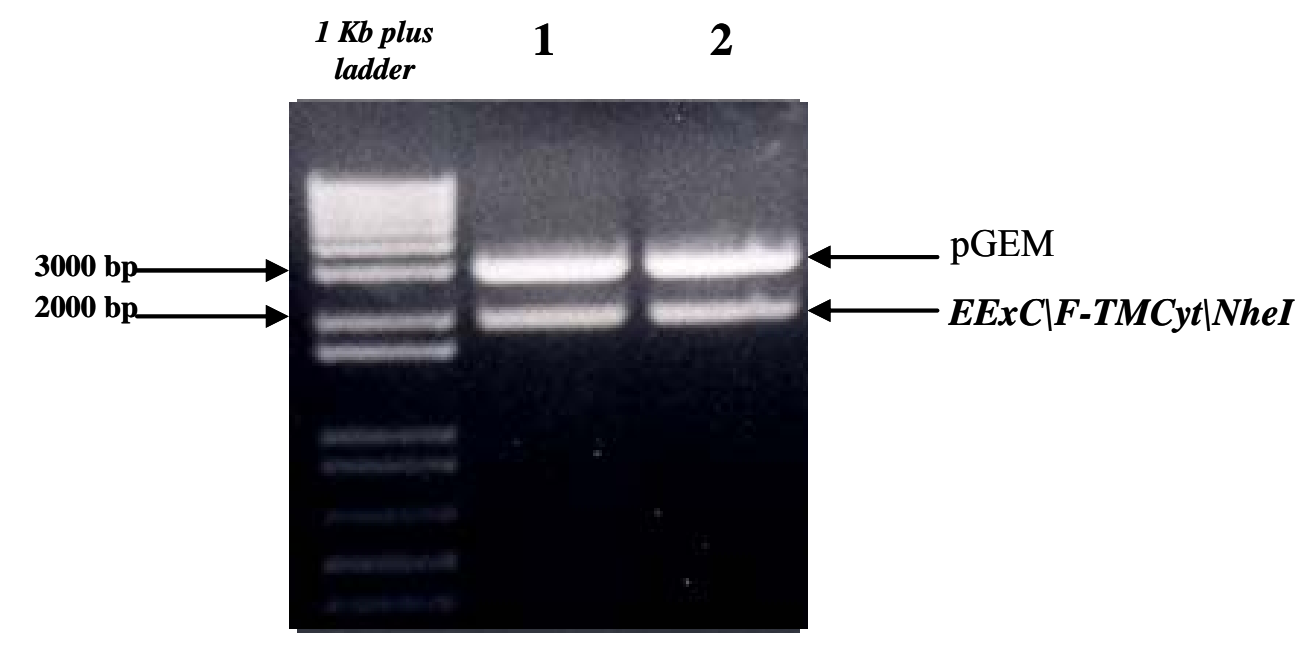

Figura 4.5.- Digestión con NheI de pGEM-EExClF-TMCyt. Electroforesis en gel de agarosa al $0.8 \%$. Se analizan dos clones positivos obtenidos como se ha comentado en el apartado anterior

\subsubsection{4.- Clonación de Endo y EExC|F-TMCyt en pNDV-B1 y pNDV-F3aa.}

Para la clonación de la ORF completa de endoglina (Endo) en los vectores con el cDNA completo del NDV, pNDV-B1 y pNDV-F3aa, tanto el producto purificado de PCR para Endo, obtenido en el apartado 4.1.1.1, como el vector pGEM-Endo construido en el apartado 4.1.1.2 se digirieron con la enzima XbaI y el fragmento de interés fue purificado desde un gel de agarosa al $0.8 \%$, tal y como se ha descrito anteriormente. Los vectores se amplificaron en cultivo bacteriano, purificaron en gradiente de cloruro de cesio según los procedimientos del apartado 3.6.2 y posteriormente digirieron con $\mathrm{XbaI}$ y desfosforilaron con CIP. Tras ello también se purificaron desde gel las formas linealizadas, para evitar el trasfondo que posteriormente pudiera provocar el bajo porcentaje no digerido de vector. Una vez se dispuso de insertos y vectores, se procedió 
a la clonación según el procedimiento descrito en el apartado 3.6.11. Las colonias resultantes se analizaron por PCR (apartado 3.6.14), empleando como cebadores Int01SecEndo y pNDV/3231- (ver Tabla 3.4), que hibrida junto al sitio XbaI en los pNDV. Las colonias con los plásmidos recombinantes en que el inserto se había introducido en el sentido correcto produjeron una amplificación de unas 600 bp, tal y como se muestra en la Figura 4.6.

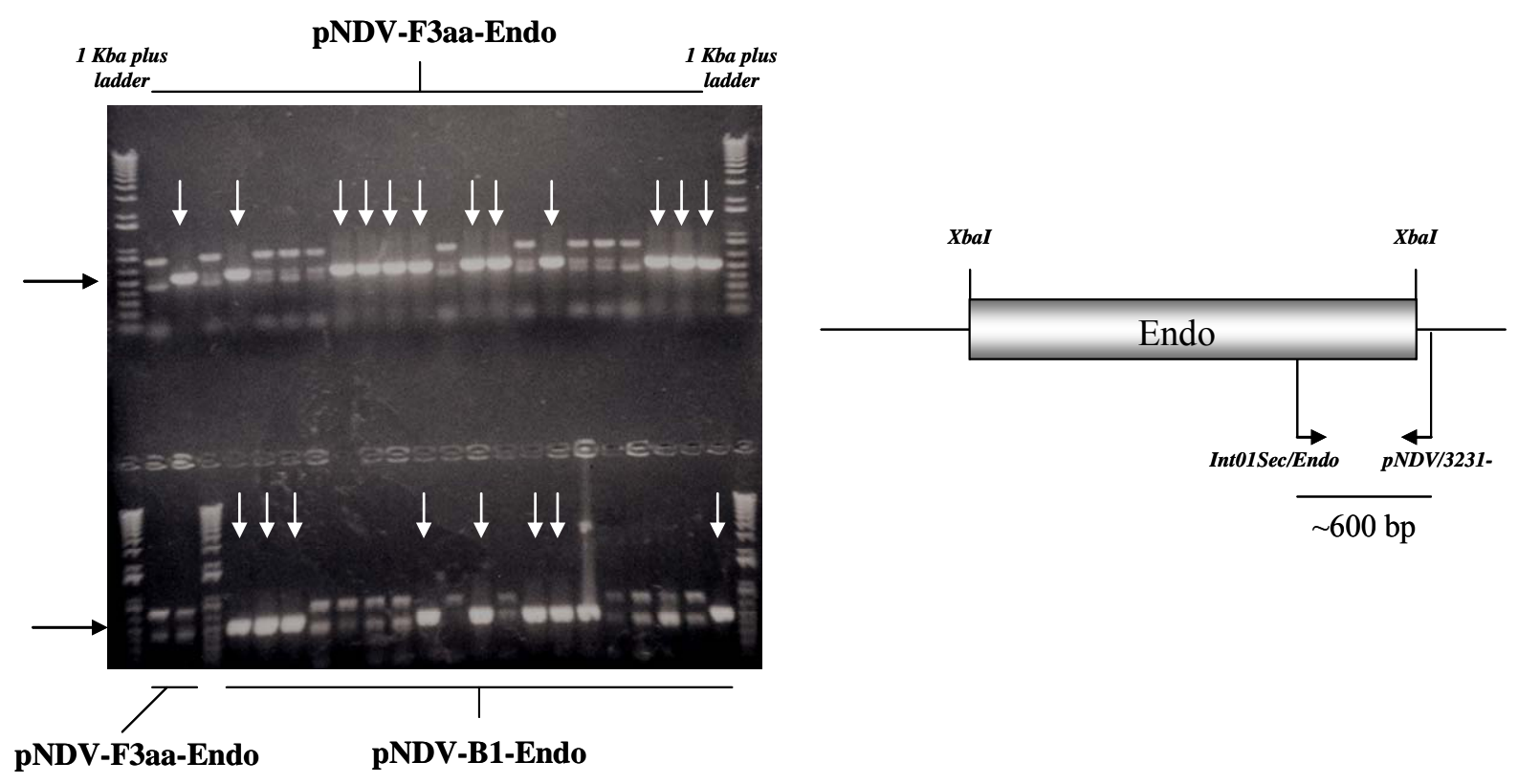

Figura 4.6.- Análisis por PCR sobre colonias con pNDV-B1-Endo y pNDVF3aa-Endo. Electroforesis en gel de agarosa al $0.8 \%$ de los productos de PCR Se indican con flechas los clones positivos, en los que se ha producido amplificación según se muestra en la Figura de la derecha

Los clones que resultaron positivos por PCR fueron analizados mediante digestión con las enzimas XbaI y SacII, para confirmar la inclusión del inserto entero y su orientación respectivamente, tal como se muestra en la Figura 4.9. Durante esta clonación se obtuvo una eficiencia mucho mayor extrayendo el inserto Endo de pGEM que digiriéndolo directamente tras la PCR.

Para la clonación de la secuencia de la quimera EExC/F-TMCyt en los vectores pNDV-B1 y pNDV-F3aa, en primer lugar se extrajo el fragmento que la contenía en el vector pGEM-EExC/F-TMCyt digiriéndolo con la endonucleasa NheI. Los productos de la reacción de digestión fueron sometidos a electroforesis en gel de agarosa al $0.8 \%$ y se purificó la banda correspondiente al fragmento de interés. La clonación se llevó a cabo 

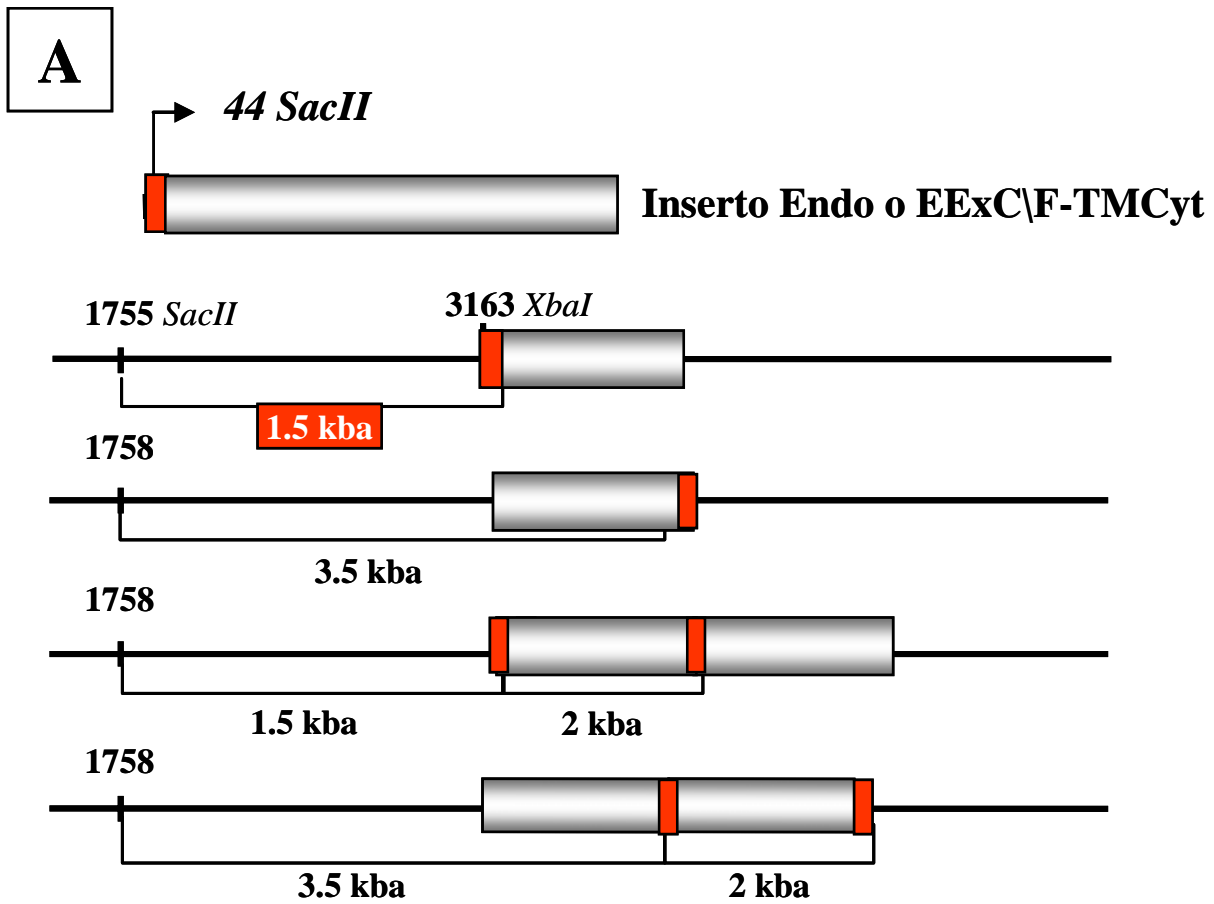

\section{B}
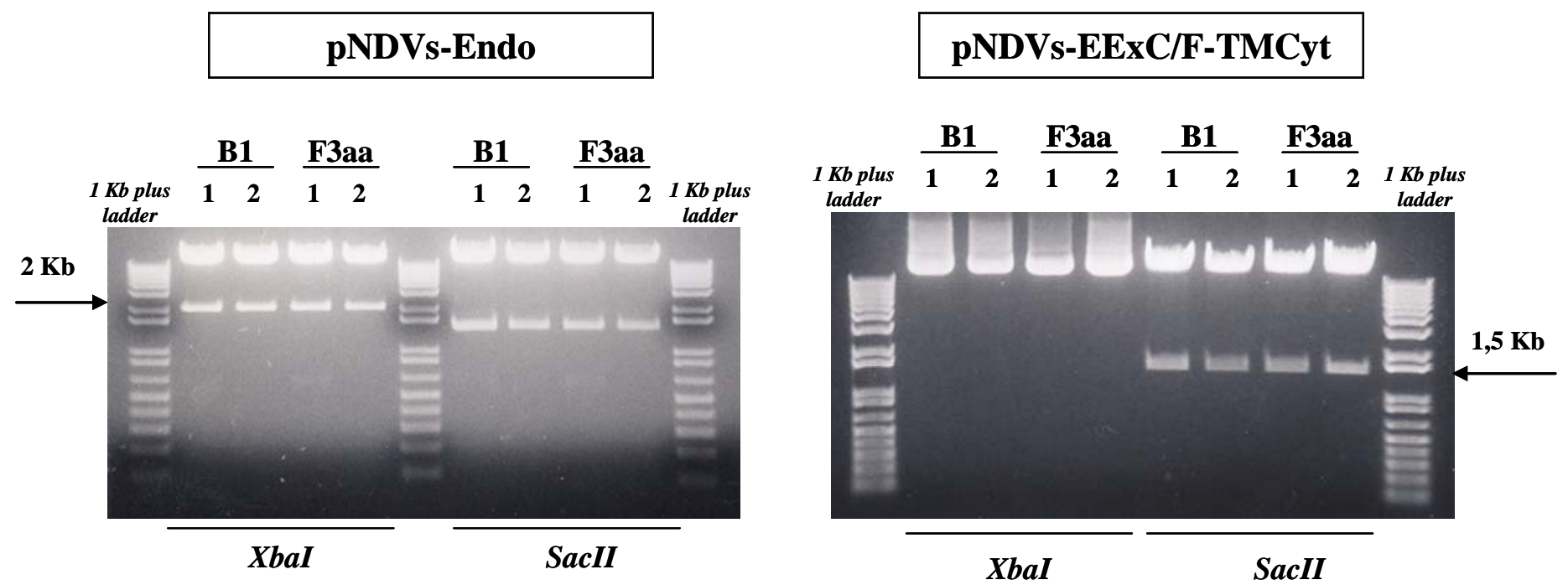

Figura 4.9.- Análisis de restricción de pNDVs-Endo y pNDVs-EExC/F-TMCyt.

(A).- Esquema que muestra las distintas posibilidades de corte con SacII en función del número y orientación de los insertos en pNDV; pNDV-B1 y F3aa tiene un único sitio SacII en la posición 1755 (ver apartado 3.5.6.4), y endoglina en posición 9 de su ORF (posición 44 del inserto creado por PCR). (B).- Electroforesis en gel de agarosa al $0.8 \%$ de las reacciones de digestión. Los clones pNDV-Endo muestran tener un inserto XbaI de $2 \mathrm{~Kb}$ y uno SacII de 1.5 $\mathrm{Kb}$, lo que se corresponde con la ORF de endoglina entera y clonada en sentido adecuado. Los clones pNDV- EExC/F-TMCyt han perdido el sitio XbaI por inclusión del inserto NheI, y presentan un correcto patrón de digestión SacII. 
Una vez seleccionados los clones con pNDV-B1-Endo, pNDV-F3aa-Endo, pNDV-B1-EExC/F-TMCyt y pNDV-F3aa-EExC/F-TMCyt, se tomaron aleatoriamente dos de cada uno de ellos, se obtuvo una gran cantidad de su DNA plasmídico con el procedimiento descrito en 3.6.1 y se procedió a su secuenciación.

\subsubsection{5.- Secuenciación de pNDV-Endo y pNDV-EExC/F-TMCyt.}

Los plásmidos seleccionados se secuenciaron siguiendo el procedimiento descrito en el apartado 3.6.18 para asegurar que el inserto deseado se había introducido correctamente y sin ninguna mutación. La estrategia de secuenciación de los mismos se muestra en la Figura 4.10, y las secuencias obtenidas para los insertos en las Figuras 4.11 y 4.12. Los oligonucleótidos empleados pueden consultarse en la Tabla 3.4.
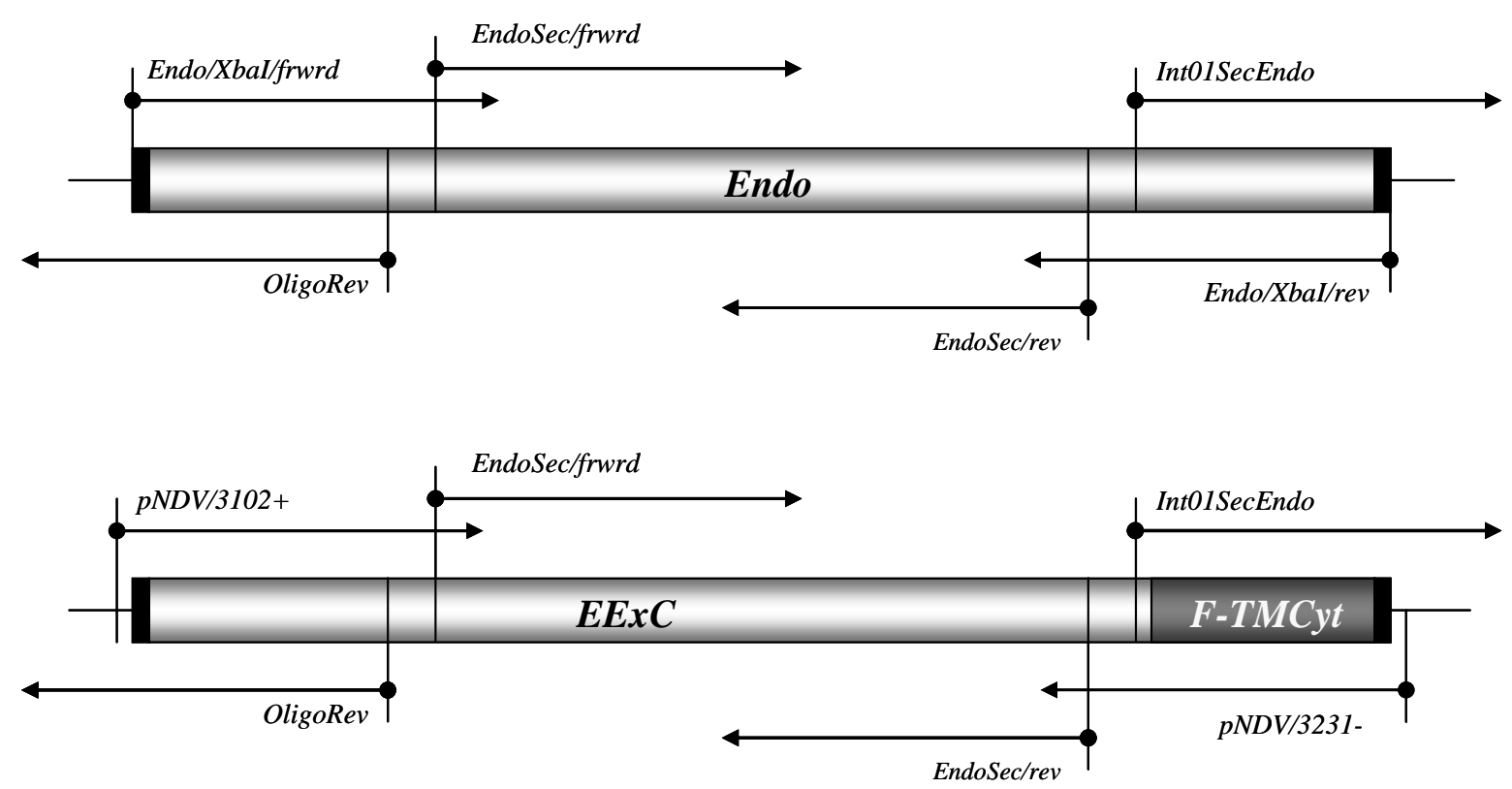

Figura 4.10.- Estrategia de secuenciación de los insertos Endo y EExC/F-TMCyt, presentes en los plásmidos pNDV-B1-Endo, pNDVF3aa-Endo, pNDV-B1-EExC/F-TMCyt y pNDV-F3aa-EExC/F-TMCyt 
1 TCTAGATTAGAAAAAATACGgGTAGAACCGCCACCATGGACCGCGGCACGCTCCCTCTGG $6 \odot$

$$
\begin{array}{llllllll}
M & D & R & G & T & L &
\end{array}
$$

61 CTGTTGCCCTGCTGCTGGCCAGCTGCAGCCTCAGCCCCACAAGTCTTGCAGAAACAGTCC 120

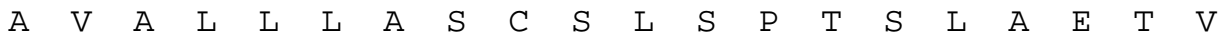

121 ATTGTGACCTTCAGCCTGTGGGCCCCGAGAGGGGCGGGTGACATATACCACTAGCCAGG 180

$\begin{array}{llllllllllllllllllll}H & C & D & L & Q & P & V & G & P & E & R & G & E & V & T & Y & T & T & S & Q\end{array}$

181 TCTCGAAGGGCTGCGTGGCTCAGGCCCCCAATGCCATCCTTGAAGTCCATGTCCTCTTCC 240

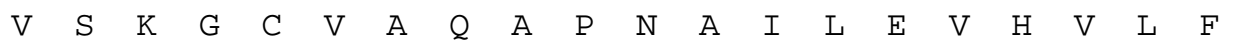

241 TGGAGTTCCCAACGGGCCCGTCACAGCTGGAGCTGACTCTCCAGGCATCCAAGCAAAATG 300 L

301 GCACCTGGCCCCGAGAGGTGCTTCTGGTCCTCAGTGTAAACAGCAGTGTCTTCCTGCATC 360 $\begin{array}{llllllllllllllllllll}G & T & W & P & R & E & V & L & L & V & L & S & V & N & S & S & V & F & L & H\end{array}$

361 TCCAGGCCCTGGGAATCCCACTGCACTTGGCCTACAATTCCAGCCTGGTCACCTTCCAAG 420 $\begin{array}{llllllllllllllllllll}L & Q & A & L & G & I & P & L & H & L & A & Y & N & S & S & L & V & T & F & Q\end{array}$

421 AGCCCCCGGGGGTCAACACCACAGAGCTGCCATCCTTCCCCAAGACCCAGATCCTTGAGT 480 $\begin{array}{llllllllllllllllllll}E & P & P & G & V & N & T & T & E & L & P & S & F & P & K & T & Q & I & L & E\end{array}$

481 GGGCAGCTGAGAGGGGCCCCATCACCTCTGCTGCTGAGCTGAATGACCCCCAGAGCATCC 540 W

541 TCCTCCGACTGGGCCAAGCCAGGGGTCACTGTCCTTCTGCATGCTGGAGCCAGCCAGG 600 $\begin{array}{lllllllllllllllllllll}L & L & R & L & G & Q & A & Q & G & S & L & S & F & C & M & L & E & A & S & Q\end{array}$

601 ACATGGGCCGCACGCTCGAGTGGCGGCCGCGTACTCCAGCCTTGGTCCGGGGCTGCCACT $66 \odot$ $\begin{array}{lllllllllllllllllllll}D & M & G & R & T & L & E & W & R & P & R & T & P & A & L & V & R & G & C & H\end{array}$

661 TGGAAGGCGTGGCCGGCCACAAGGAGGCGCACATCCTGAGGGTCCTGCCGGGCCACTCGG 720 $\begin{array}{llllllllllllllllllll}L & E & G & V & A & G & H & K & E & A & H & I & L & R & V & L & P & G & H & S\end{array}$

721 CCGGGCCCCGGACGGTGACGGTGAAGGTGGAACTGAGCTGCGCACCCGGGGATCTCGATG 780 $\begin{array}{llllllllllllllllllll}A & G & P & R & T & V & T & V & K & V & E & L & S & C & A & P & G & D & L & D\end{array}$

781 CCGTCCTCATCCTGCAGGGTCCCCCCTACGTGTCCTGGCTCATCGACGCCAACCACAACA 840

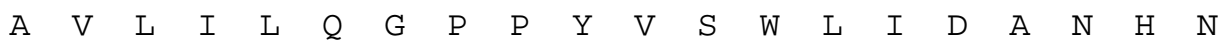

841 TGCAGATCTGGACCACTGGAGAATACTCCTTCAAGATCTTTCCAGAGAAAACATTCGTG 900 $\begin{array}{lllllllllllllllllllll}M & Q & I & W & T & T & G & E & Y & S & F & K & I & F & P & E & K & N & I & R\end{array}$

901 GCTTCAAGCTCCCAGACACACCTCAAGGCCTCCTGGGGGAGGCCGGATGCTCAATGCCA 960 $\begin{array}{lllllllllllllllllllllllll}G & F & K & L & P & D & T & P & Q & G & L & L & G & E & A & R & M & L & N & A\end{array}$

961 GCATTGTGGCATCCTTCGTGGAGCTACCGCTGGCCAGCATTGTCTCACTTCATGCCTCCA 1020 $\begin{array}{llllllllllllllllllllll}S & I & V & A & S & F & V & E & L & P & L & A & S & I & V & S & L & H & A & S\end{array}$

1021 GCTGCGGTGGTAGGCTGCAGACCTCACCCGCACCGATCCAGACCACTCCTCCCAAGGACA 1080 $\begin{array}{llllllllllllllllllll}S & C & G & G & R & L & Q & T & S & P & A & P & I & Q & T & T & P & P & K & D\end{array}$

1081 CTTGTAGCCCGGAGCTGCTCATGTCCTTGATCCAGACAAAGTGTGCCGACGACGCCATGA 1140 $\begin{array}{llllllllllllllllllllllllll}T & C & S & P & E & L & L & M & S & L & I & Q & T & K & C & A & D & D & A & M\end{array}$

1141 CCCTGGTACTAAAGAAAGAGCTTGTTGCGCATTTGAAGTGCACCATCACGGGCCTGACCT 1200 $\begin{array}{llllllllllllllllllllll}T & L & V & L & K & K & E & L & V & A & H & L & K & C & T & I & T & G & L & T\end{array}$ 
1201 TCTGGGACCCCAGCTGTGAGGCAGAGGACAGGGGTGACAAGTTTGTCTTGCGCAGTGCTT 1260

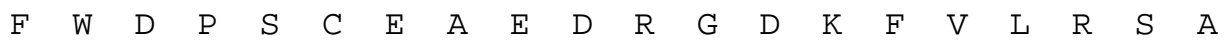

1261 ACTCCAGCTGTGGCATGCAGGTGTCAGCAAGTATGATCAGCAATGAGGCGGTGGTCAATA 1320

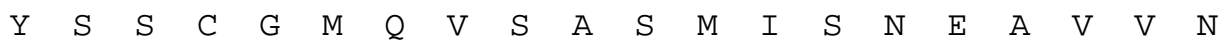

1321 TCCTGTCGAGCTCATCACCACAGCGGAAAAAGGTGCACTGCCTCAACATGGACAGCCTCT 1380 $\begin{array}{llllllllllllllllllllllllll} & I & L & S & S & S & S & P & Q & R & K & K & V & H & C & L & N & M & D & S & L\end{array}$

1381 CTTTCCAGCTGGGCCTCTACCTCAGCCCACACTTCCTCCAGGCCTCCAACACCATCGAGC 1440 $\begin{array}{lllllllllllllllllllllllll}S & F & Q & L & G & L & Y & L & S & P & H & F & L & Q & A & S & N & T & I & E\end{array}$

1441 CGGGGCAGCAGAGCTTTGTGCAGGTCAGAGTGTCCCCATCCGTCTCCGAGTTCCTGCTCC 1500 $\begin{array}{llllllllllllllllllllllllllll}P & G & Q & Q & S & F & V & Q & V & R & V & S & P & S & V & S & E & F & L & L\end{array}$

1501 AGTTAGACAGCTGCCACCTGGACTTGGGGCCTGAGGGAGGCACCGTGGAACTCATCCAGG 1560

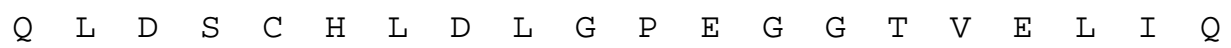

1561 GCCGGGCGGCCAAGGGCAACTGTGTGAGCCTGCTGTCCCCAAGCCCCGAGGGTGACCCGC 1620 $\begin{array}{llllllllllllllllllllll}G & R & A & A & K & G & N & C & V & S & L & L & S & P & S & P & E & G & D & P\end{array}$

1621 GCTTCAGCTTCCTCCTCCACTTCTACACAGTACCCATACCCAAAACCGGCACCCTCAGCT 1680 $\begin{array}{llllllllllllllllllll}R & F & S & F & L & L & H & F & Y & T & V & P & I & P & K & T & G & T & L & S\end{array}$

1681 GCACGGTAGCCCTGCGTCCCAAGACCGGGTCTCAAGACCAGGAAGTCCATAGGACTGTCT 1740 $\begin{array}{lllllllllllllllllllllllllll}C & T & V & A & L & R & P & K & T & G & S & Q & D & Q & E & V & H & R & T & V\end{array}$

1741 TCATGCGCTTGAACATCATCAGCCCTGACCTGTCTGGTTGCACAAGCAAAGGCCTCGTCC 1800

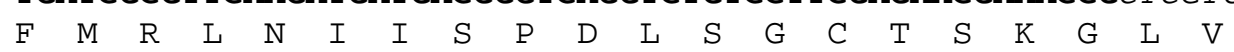

1801 TGCCCGCCGTGCTGGGCATCACCTTTGGTGCCTTCCTCATCGGGGCCCTGCTCACTGCTG 1860 $\begin{array}{lllllllllllllllllllll}L & P & A & V & L & G & I & T & F & G & A & F & L & I & G & A & L & L & T & A\end{array}$

1861 CACTCTGGTACATCTACTCGCACACGCGTTCCCCCAGCAAGCGGGAGCCCGTGGTGGCGG 1920

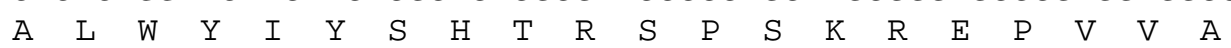

1921 TGGCTGCCCCGGCCTCCTCGGAGAGCAGCAGCACCAACCACAGCATCGGGAGCACCCAGA 1980 $\begin{array}{lllllllllllllllllllll}V & A & A & P & A & S & S & E & S & S & S & T & N & H & S & I & G & S & T & Q\end{array}$

1981 GCACCCCCTGCTCCACCAGCAGCATGGCATAGCCCCTCTAGA 2022

S $\quad \mathrm{T}$ P

Figura 4.11.- Secuencia de L-endoglina humana en pNDV-B1-Endo y pNDV-F3aa-Endo. Se incluyen en color las secuencias añadidas (ver apartado 3.6.8). Los codones de inicio y terminación se muestran en rojo subrayado, el dominio transmembrana en cursiva y el dominio citoplasmático en negrita y cursiva. 
TCTAGCTTAGAAAAATACGgGTAGAACACTAgTCGACCGCCACCATGGACCGCGGCACG 60 $\begin{array}{lllll}M & D & R & G & T\end{array}$

61 CTCCCTCTGGCTGTTGCCCTGCTGCTGGCCAGCTGCAGCCTCAGCCCCACAAGTCTTGCA 120 $\begin{array}{llllllllllllllllllll}L & P & L & A & V & A & L & L & L & A & S & C & S & L & S & P & T & S & L & A\end{array}$

121 GAAACAGTCCATTGTGACCTTCAGCCTGTGGGCCCGAGAGGGGCGAGGTGACATATACC 180

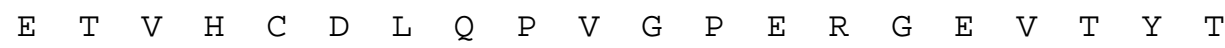

181 ACTAGCCAGgTCTCGAAGGGCTGCGTGGCTCAGGCCCCCAATGCCATCCTTGAAGTCCAT 240 $\begin{array}{lllllllllllllllllllllllllllllllll}T & S & Q & V & S & K & G & C & V & A & Q & A & P & N & A & I & L & E & V & H\end{array}$

241 GTCCTCTTCCTGGAGTTCCCAACGGGCCGTCACAGCTGGAGCTGACTCTCCAGGCATCC $30 \odot$ $\begin{array}{llllllllllllllllllll}V & L & F & L & E & F & P & T & G & P & S & Q & L & E & L & T & L & Q & A & S\end{array}$

301 AAGCAAAATGGCACCTGGCCCGAGAGGTGCTTCTGGTCCTCAGTGTAAACAGCAGTGTC 360 $\begin{array}{llllllllllllllllllll}K & Q & N & G & T & W & P & R & E & V & L & L & V & L & S & V & N & S & S & V\end{array}$

361 TTCCTGCATCTCCAGGCCCTGGGAATCCCACTGCACTTGGCCTACAATTCCAGCCTGGTC 420 $\begin{array}{lllllllllllllllllllll} & \text { L } & L & H & L & Q & A & L & G & I & P & L & H & L & A & Y & N & S & S & L & V\end{array}$

421 ACCTTCCAAGAGCCCCCGGGGTCAACACCACAGAGCTGCCATCCTTCCCCAAGACCCAG 480 $\begin{array}{llllllllllllllllllll}T & F & Q & E & P & P & G & V & N & T & T & E & L & P & S & F & P & K & T & Q\end{array}$

481 ATCCTTGAGTGGGAGCTGAGAGgGGCCCATCACCTCTGCTGCTGAGCTGAATGACCCC 540 $\begin{array}{llllllllllllllllllll}I & L & E & W & A & A & E & R & G & P & I & T & S & A & A & E & L & N & D & P\end{array}$

541 CAGAGCATCCTCCTCCGACTGGGCCAAGCCAGGGGTCACTGTCCTTCTGCATGCTGGAA 600 $\begin{array}{llllllllllllllllllll}Q & S & I & L & L & R & L & G & Q & A & Q & G & S & L & S & F & C & M & L & E\end{array}$

601 GCCAGCCAGGACATGGGCCGCACGCTCGAGTGGCGGCCGCGTACTCCAGCCTTGGTCCGG 660 $\begin{array}{lllllllllllllllllllll}A & S & Q & D & M & G & R & T & L & E & W & R & P & R & T & P & A & L & V & R\end{array}$

661 GGCTGCCACTTGGAAGGCGTGGCCGGCCACAAGGAGGCGCACATCCTGAGGGTCCTGCCG 720

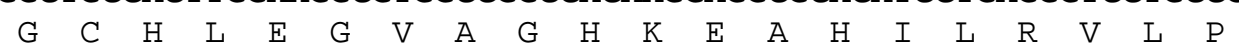

721 GGCCACTCGGCCGGGCCCGGACGGTGACGGTGAAGGTGGACTGAGCTGCGCACCCGGG 780 $\begin{array}{lllllllllllllllllllll}G & H & S & A & G & P & R & T & V & T & V & K & V & E & L & S & C & A & P & G\end{array}$

781 GATCTCGATGCCGTCCTCATCCTGCAGGGTCCCCCCTACGTGTCCTGGCTCATCGACGCC 840 $\begin{array}{llllllllllllllllllll}D & L & D & A & V & L & I & L & Q & G & P & P & Y & V & S & W & L & I & D & A\end{array}$

841 AACCACAACATGCAGATCTGGACCACTGGAGAATACTCCTTCAAGATCTTTCCAGAGAAA 900 $\begin{array}{llllllllllllllllllll}N & H & N & M & Q & I & W & T & T & G & E & Y & S & F & K & I & F & P & E & K\end{array}$

901 AACATTCGTGGCTTCAAGCTCCCAGACACACCTCAAGGCCTCCTGGGGGAGGCCCGGATG 960 $\begin{array}{llllllllllllllllllll}N & I & R & G & F & K & L & P & D & T & P & Q & G & L & L & G & E & A & R & M\end{array}$

961 CTCAATGCCAGCATTGTGGCATCCTTCGTGGAGCTACCGCTGGCCAGCATTGTCTCACTT 1020 $\begin{array}{llllllllllllllllllll}L & N & A & S & I & V & A & S & F & V & E & L & P & L & A & S & I & V & S & L\end{array}$

1021 CATGCCTCCAGCTGCGGTGGTAGGCTGCAGACCTCACCCGCACCGATCCAGACCACTCCT 1080 $\begin{array}{llllllllllllllllllll}H & A & S & S & C & G & G & R & L & Q & T & S & P & A & P & I & Q & T & T & P\end{array}$

1081 CCCAAGGACACTTGTAGCCCGGAGCTGCTCATGTCCTTGATCCAGACAAAGTGTGCCGAC 1140 $\begin{array}{llllllllllllllllllll}P & K & D & T & C & S & P & E & L & L & M & S & L & I & Q & T & K & C & A & D\end{array}$

1141 GACGCCATGACCCTGGTACTAAAGAAAGAGCTTGTTGCGCATTTGAAGTGCACCATCACG 1200 $\begin{array}{llllllllllllllllllll}D & A & M & T & L & V & L & K & K & E & L & V & A & H & L & K & C & T & I & T\end{array}$ 
1201 GGCCTGACCTTCTGGGACCCCAGCTGTGAGGCAGAGGACAGGGGTGACAAGTTTGTCTTG 1260 $\begin{array}{llllllllllllllllllllll}G & L & T & F & W & D & P & S & C & E & A & E & D & R & G & D & K & F & V & L\end{array}$

1261 CGCAGTGCTTACTCCAGCTGTGGCATGCAGGTGTCAGCAAGTATGATCAGCAATGAGGCG 1320 $\begin{array}{lllllllllllllllllllllllllll}R & S & A & Y & S & S & C & G & M & Q & V & S & A & S & M & I & S & N & E & A\end{array}$

1321 GTGGTCAATATCCTGTCGAGCTCATCACCACAGCGGAAAAGGTGCACTGCCTCAACATG 1380 $\begin{array}{lllllllllllllllllllllll}V & V & N & I & L & S & S & S & S & P & Q & R & K & K & V & H & C & L & N & M\end{array}$

1381 GACAGCCTCTCTTTCCAGCTGGGCCTCTACCTCAGCCCACACTTCCTCCAGGCCTCCAAC 1440 $\begin{array}{lllllllllllllllllllllllll}D & S & L & S & F & Q & L & G & L & Y & L & S & P & H & F & L & Q & A & S & N\end{array}$

1441 ACCATCGAGCCGGGGCAGCAGAGCTTTGTGCAGGTCAGAGTGTCCCCATCCGTCTCCGAG 1500 $\begin{array}{llllllllllllllllllll}T & I & E & P & G & Q & Q & S & F & V & Q & V & R & V & S & P & S & V & S & E\end{array}$

1501 TTCCTGCTCCAGTTAGACAGCTGCCACCTGGACTTGGGGCCTGAGGGAGGCACCGTGGAA 1560 $\begin{array}{lllllllllllllllllllllll} & \text { L } & L & L & Q & L & D & S & C & H & L & D & L & G & P & E & G & G & T & V & E\end{array}$

1561 CTCATCCAGGGCCGGGCGGCCAAGGGCACTGTGTGAGCCTGCTGTCCCCAAGCCCCGAG 1620 $\begin{array}{llllllllllllllllllllll}L & I & Q & G & R & A & A & K & G & N & C & V & S & L & L & S & P & S & P & E\end{array}$

1621 GGTGACCCGCGCTTCAGCTTCCTCCTCCACTTCTACACAGTACCCATACCCAAAACCGGC 1680 $\begin{array}{lllllllllllllllllllllll}G & D & P & R & F & S & F & L & L & H & F & Y & T & V & P & I & P & K & T & G\end{array}$

1681 ACCCTCAGCTGCACGGTAGCCCTGCGTCCCAAGACCGGGTCTCAAGACCAGGAAGTCCAT 1740

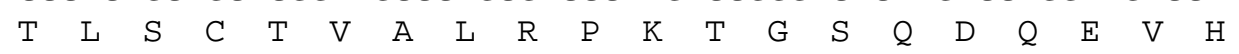

1741 AGGACTGTCTTCATGCGCTTGAACATCATCAGCCCTGACCTGTCTGGTTGCACAAGCAAA 1800 $\begin{array}{llllllllllllllllllll}R & T & V & F & M & R & L & N & I & I & S & P & D & L & S & G & C & T & S & K\end{array}$

1801 GGCGTTAACCTCATTACCTATATCGTTTTGACTATCATATCTCTTGTTTTTGGTATACTT 1860 1861 AGCCTGATTCTAGCATGCTACCTAATGTACAAGCAAAAGGCGCAACAAAAGACCTTATTA 1920 $\begin{array}{llllllllllllllllllll}G & V & N & L & I & T & Y & I & V & L & T & I & I & S & L & V & F & G & I & L\end{array}$ $\begin{array}{lllllllllllllllllllllll}S & L & I & L & A & C & Y & L & M & Y & K & Q & K & A & Q & Q & K & T & L & L\end{array}$

1921 TGGCTTGGGAATAATACCCTAGATCAGATGAGAGCCACTACAAAAATGTGATAAGCTAGA 1980 \begin{tabular}{llllllllllllllllllll}
$W$ & $\mathrm{~L}$ & $\mathrm{G}$ & $\mathrm{N}$ & $\mathrm{N}$ & $\mathrm{T}$ & $\mathrm{L}$ & $\mathrm{D}$ & $\mathrm{Q}$ & $\mathrm{M}$ & $\mathrm{R}$ & $\mathrm{A}$ & $\mathrm{T}$ & $\mathrm{T}$ & $\mathrm{K}$ & $\mathrm{M}$ & * & \\
\hline
\end{tabular}

Figura 4.12.- Secuencia de la quimera con el dominio extracelular de Lendoglina y los dominios transmembrana y citoplasmático de NDV F en pNDV-B1-EExC/F-TMCyt y pNDV-F3aa-EExC/F-TMCyt. Se incluyen en color las secuencias añadidas (ver apartado 3.6.8). Los codones de inicio y terminación se muestran en rojo subrayado; las secuencias procedentes de pGEM-NDV-F/TMCyt se muestran sobre fondo amarillo y entre ellas el dominio transmembrana de $\mathrm{F}$ aparece en cursiva y el dominio citoplasmático en negrita y cursiva. La secuencia híbrida XbaI/NheI aparece subrayada en los extremos de la secuencia 


\subsection{2.- RESCATE DE LOS VIRUS RECOMBINANTES rNDV-Endo y rNDV-EExC/F-TMCyt.}

El rescate de los virus recombinantes con el genoma codificado en los plásmidos antes construidos se llevó a cabo empleando la metodología descrita en el apartado 3.7. La Figura 4.13 muestra un esquema general del proceso.

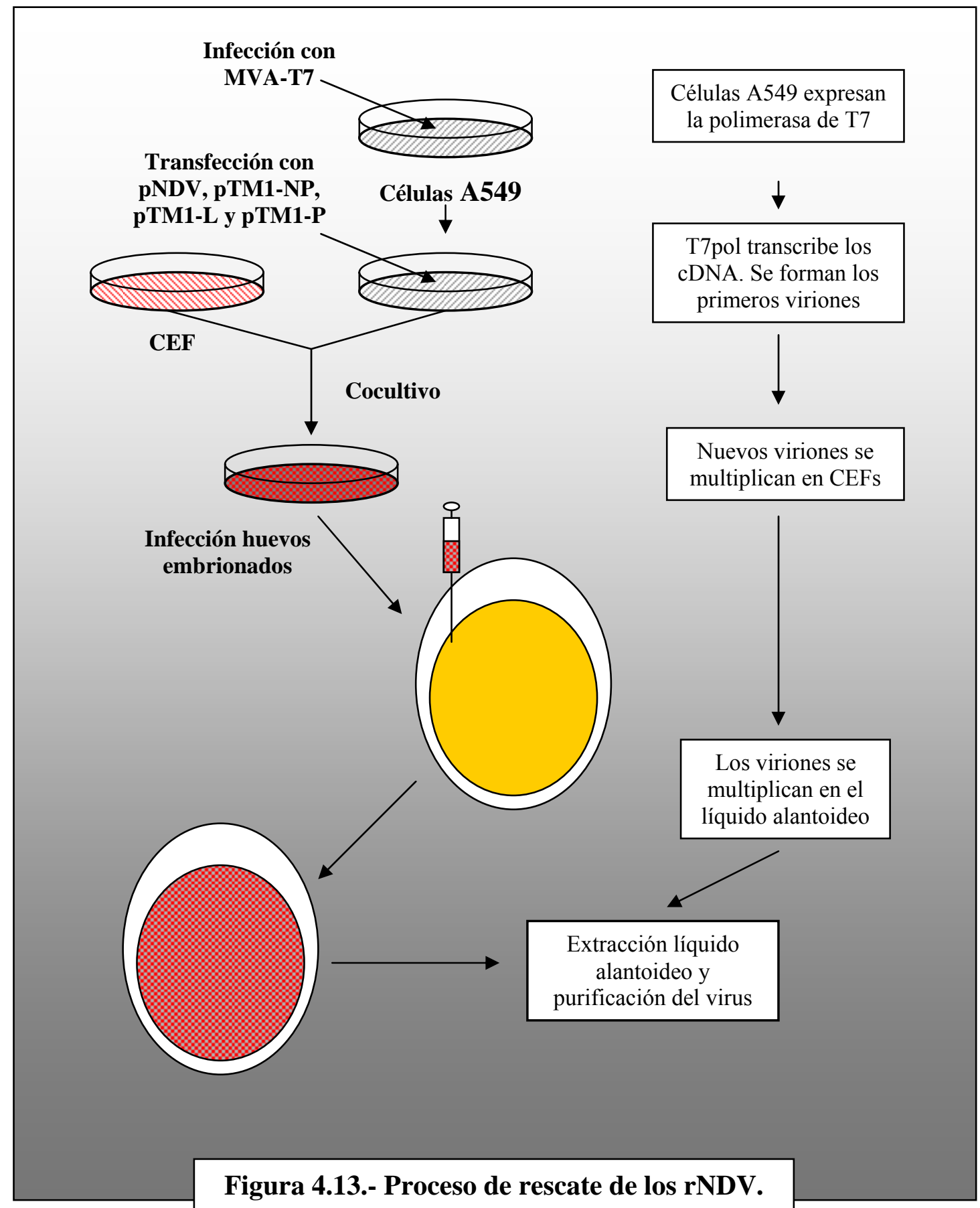


El proceso se llevó a cabo por triplicado para cada uno de los clones seleccionados según se ha descrito en el apartado anterior. Células A549 a un 90\% de confluencia en placas de $35 \mathrm{~mm}$ se infectaron con virus vaccinia MVA-T7 a una multiplicidad de infección (m.o.i.) de 1, y posteriormente se transfectaron con los distintos plásmidos recombinantes junto con pTM1-NP, pTM1-L y pTM1-P, empleando el sistema Lipofectamina-OptiMEM. El medio de transfección se retiró a las 8 horas y a las 24 horas postransfección las células A549 se cocultivaron con fibroblastos embrionarios de pollo en placas de $100 \mathrm{ml}$. Las placas se observaron diariamente para seguir el nivel de daño celular, principalmente causado por MVA-T7. Entre 3 y 5 días tras el cocultivo, según el grado de citopaticidad, el sobrenadante de las placas se empleó para inocular huevos embrionados libres de patógenos de 9-11 días. Entre 2 y 3 días después de la inoculación, se recogió el líquido alantoideo y se sometió a un ensayo de hemaglutinación (apartado 3.9.1). En los casos en que el título de virus no fue muy alto (menos de 10 pocillos positivos en la placa de hemaglutinación), se efectuó un nuevo pase en huevos, de la misma manera que el primero, para obtener una mayor amplificación. El líquido alantoideo con un título hemaglutinante suficiente se empleó para inocular nuevos huevos embrionados, de donde se purificaron definitivamente los virus recombinantes rNDV-B1-Endo, rNDV-F3aa-Endo, rNDV-B1-EExC/F-TMCyt y rNDV-F3aa-EExC/F-TMCyt.

\subsection{3.- DETERMINACIÓN DE LA EXPRESIÓN DE ENDOGLINA EN CÉLULAS INFECTADAS}

La expresión de endoglina o la de su quimera por virus recombinantes fue comprobada mediante inmunofluorescencia en células Vero infectadas, tal y como se describe en el apartado 3.8.1. Las células se infectaron directamente con el líquido alantoideo que había resultado positivo en el ensayo de hemaglutinación y se realizó un doble marcaje con el anticuerpo monoclonal P3D1 anti-endoglina humana, procedente de hibridoma de ratón, y un suero policlonal de conejo anti-NDV. Como control positivo se infectaron las células con el virus rNDV-F3aa-mRFP, que expresa la proteína fluorescente monomérica roja. La Figura 4.14 muestra los resultados de la inmunofluorescencia: en todos los casos se apreció un alto nivel de expresión de endoglina, así como una ausencia de reactividad cruzada del anticuerpo $\alpha$-endoglina con 


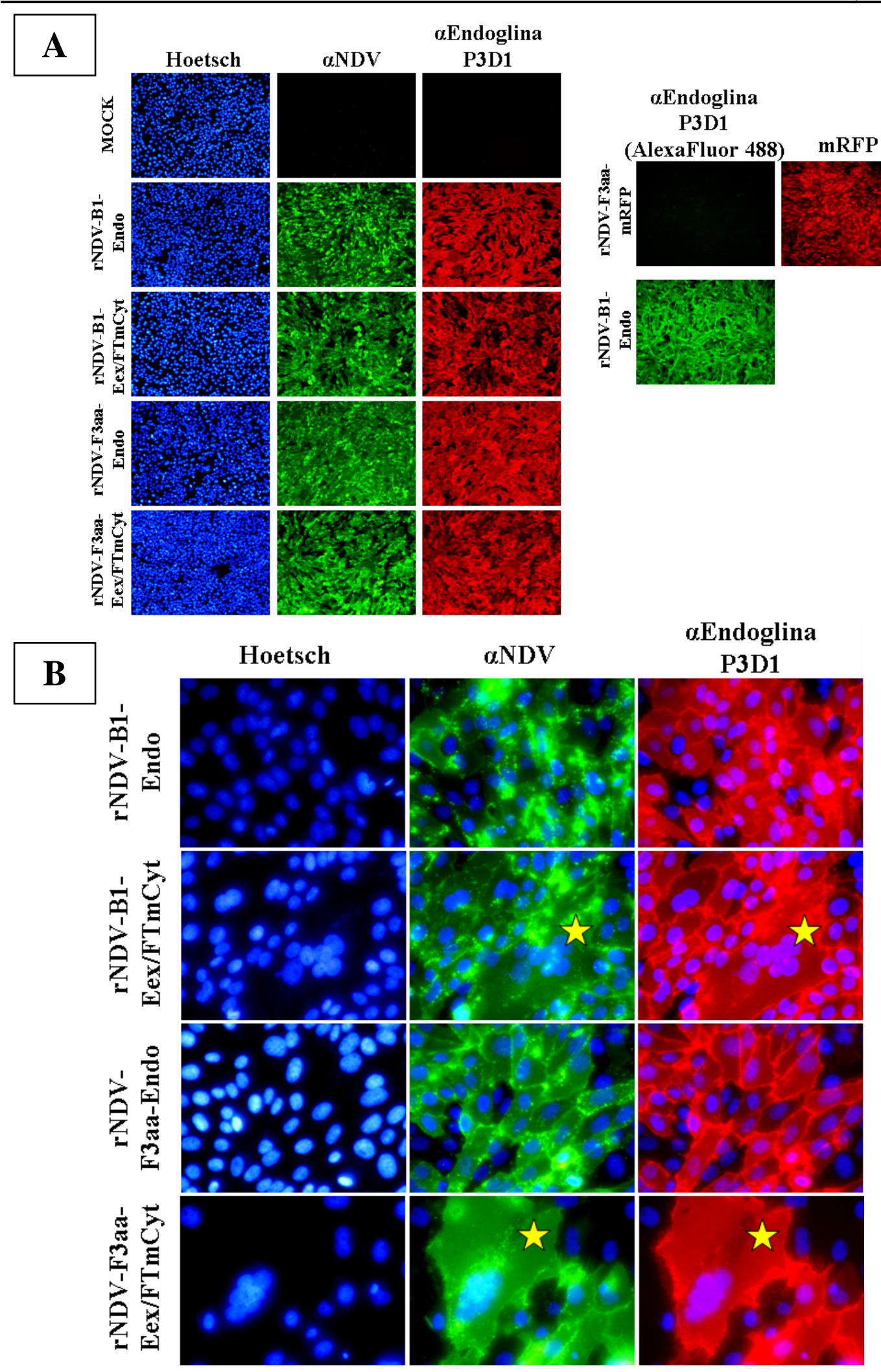

Figura 4.14.- Inmunofluorescencia sobre células infectadas con los rNDV-Endo y rNDV-EExC/F-TMCyt. (A).- Micrografías de campos representativos (10X) de células Vero infectadas con los distintos virus y marcadas con anticuerpos antiendoglina (rojo) y anti-NDV (verde), así como controles de infección (dcha). (B).Micrografías (40X) de células Vero infectadas con los distintos recombinantes. Se indican con estrellas los sincitios formados por los rNDV-F3aa 
cualquiera de las proteínas víricas (Figura 4.14A, dcha). Las únicas diferencias observables se debieron al título infectivo de virus rescatados. Las células no fueron permeabilizadas, por lo que las proteínas detectadas se encuentran en la superficie de las mismas. También pueden apreciarse los sincitios formados por los rNDV-F3aa, que no aparecen en los rNDV-B1 pues en ningún caso se activó exógenamente el precursor $\mathrm{F}_{0}$.

La expresión de endoglina en las células infectadas también fue analizada por Western Blot tal y como se describe en los apartados 3.8.4 y 3.8.6. Previamente, el título de virus presente en el líquido alantoideo recuperado de los distintos huevos se determinó por inmunofluorescencia, y con cada uno de los distintos tipos se infectaron células Vero a una multiplicidad de infección (m.o.i.) de aproximadamente uno. Transcurridas 48 horas postinfección, se obtuvieron los extractos de las células infectadas como se ha descrito en el apartado 3.8.2, y de ellos se determinó la concentración de proteínas totales según una modificación del método de Lowry (apartado 3.8.3). Los extractos se emplearon para hacer una electroforesis SDS-PAGE y posteriormente un Western Blot con el anticuerpo monoclonal anti-endoglina humana P4A4, que permite el reconocimiento de la forma reducida de endoglina. Como control positivo se emplearon extractos de mioblastos de rata $\mathrm{L}_{6} \mathrm{E}_{9}$, transfectados establemente por el laboratorio del Dr. Carmelo Bernabéu con el mismo clon de endoglina que se ha empleado en el presente trabajo (Letamendía et al., 1998a). Como controles negativos se emplearon células sin infectar y células infectadas con rNDV-mRFP. Los resultados obtenidos se muestran en la Figura 4.15A. La endoglina expresada por los virus muestra tener el tamaño adecuado. En comparación con los miooblastos establemente transfectados, el nivel de proteína detectada es mucho mayor.

La fidelidad del transgén expresado por los virus recombinantes se determinó por RT-PCR sobre extractos de células vero infectadas (apartados 3.6.16 y 3.6.17). El RNA del virus fue amplificado como cDNA empleando los oligonucleótidos pNDV/3102+ y 3231-, que flanquean el sitio XbaI del genoma del rNDV. El producto obtenido de la RT-PCR (Figura 4.15B) fue sometido a electroforesis en gel de agarosa: la banda deseada se purificó y se secuenció. La estrategia de secuenciación fue la misma que se ha detallado previamente (Figura 4.10) y los resultados indicaron que no había ninguna modificación en el inserto presente en los virus con respecto al cDNA a partir del cual se rescataron (secuencias en Figuras 4.11 y 4.12). Los mismos resultados se 
obtuvieron al amplificar el RNA presente en una solución de viriones purificados de los distintos rNDV (apartados 3.6.16 y 3.6.17).

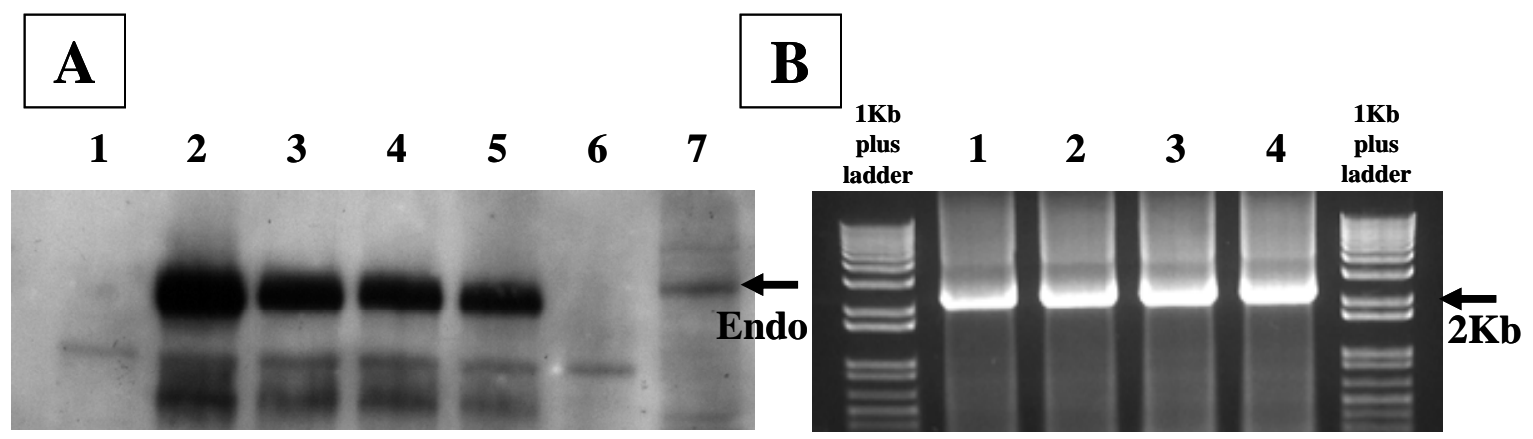

Figura 4.15.- Expresión de endoglina en células infectadas (Western Blot y RT-PCR). (A).- Western blot de extractos de células infectadas con rNDV-Endo y rNDV-EExC/F-TMCyt, realizado sobre SDS-PAGE (8\%) 1.- Células Vero sin infectar. 2-5.- Células Vero infectadas con rNDV-B1-Endo (2), rNDV-F3aa-Endo (3), rNDV-B1-EExC/F-TMCyt (4) y rNDV-F3aa-EExC/F-TMCyt (5). 6.- Células Vero infectadas con rNDV-mRFP. 7.- Mioblastos $\mathrm{L}_{6} \mathrm{E}_{9}$. En todos los casos se

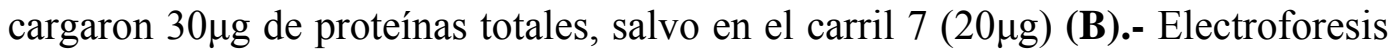
en gel de agarosa $(0.8 \%)$ de los productos de RT-PCR sobre extractos de células Vero infectadas, previa purificación para secuenciación. 1.- rNDV-B1-Endo; 2.rNDV-B1-EExC/F-TMCyt; 3.- rNDV-F3aa-Endo; 4.- rNDV-F3aa-EExC/FTMCyt. La banda amplificada se corresponde por su tamaño $(\sim 2 \mathrm{~Kb})$ a los insertos en los virus recombinantes más la región flanqueante del sitio XbaI amplificada por los cebadores empleados.

\subsection{4.- DETERMINACIÓN DE LA INCORPORACIÓN DE ENDOGLINA A LA ENVOLTURA DE LOS VIRIONES RECOMBINANTES.}

Para determinar si los viriones recombinantes estaban incorporando la endoglina o su quimera en sus envolturas, se realizó un nuevo Western-blot. Los viriones se purificaron a partir del líquido alantoideo por medio de una serie de centrifugaciones diferenciales y el uso de un colchón de sacarosa (apartado 3.7.6) y se resuspendieron en PBS. La concentración de proteínas en esta solución fue determinada mediante el método de Lowry. Las muestras se separaron mediante electroforesis en gel de poliacrilamida (8\%) en presencia de SDS (SDS-PAGE, apartado 3.8.4) y la endoglina se inmunodetectó mediante el anticuerpo monoclonal P4A4. De nuevo se utilizaron como control positivo extractos de mioblastos de rata $\mathrm{L}_{6} \mathrm{E}_{9}$, con transfección estable de endoglina humana, y como control negativo rNDV-mRFP purificado. Los resultados se muestran en la Figura 4.16. Todos los viriones recombinantes muestran incorporar la 
proteína foránea en su envoltura, si bien los que llevan la forma quimérica EExC/FTMCyt, con el dominio citoplasmático de la proteína $\mathrm{F}$, lo hacen en una proporción mucho mayor. También se aprecia una cierta diferencia de tamaño entre las formas nativa y quimérica. Si bien es cierto que esta última es 14 aminoácidos menor por ser el dominio citoplasmático de la proteína $\mathrm{F}$ algo menor que el de endoglina, es probable que dicha diferencia de tamaño se deba más a un patrón de glicosilación distinto.
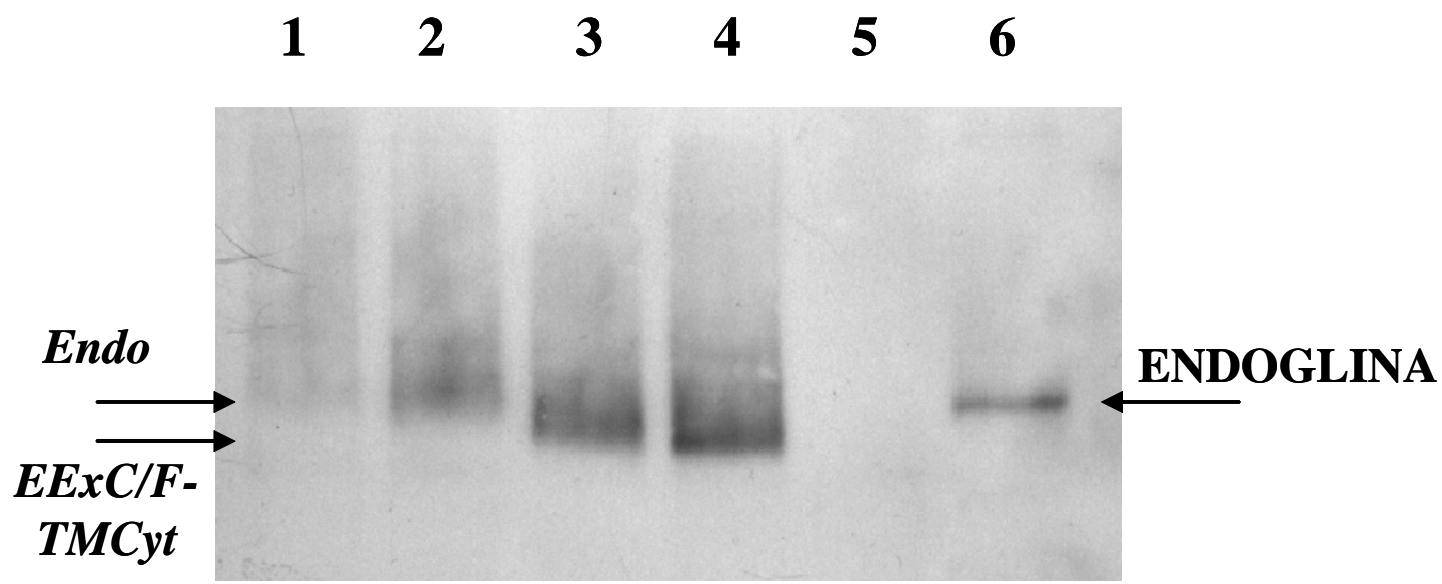

Figura 4.16.- Western Blot sobre virus rNDV-Endo y rNDV-EExC/F-TMCyt, realizado sobre SDS-PAGE (8\%) 1.- rNDV-B1-Endo. 2.- rNDV-F3aa-Endo. 3.rNDV-B1-EExC/F-TMCyt. 4.- rNDV-F3aa-EExC/F-TMCyt. 5.- Extracto celular de mioblastos $\mathrm{L}_{6} \mathrm{E}_{9}$. En los carriles de los virus se cargó $1 \mu \mathrm{g}$ de proteínas víricas totales; en el control, $20 \mu \mathrm{g}$ de proteínas procedentes del extracto celular.

La composición proteica general de los viriones recombinantes rescatados también fue analizada mediante SDS-PAGE, partiendo de la misma muestra mencionada antes. En este caso, se utilizaron geles con un gradiente del 5-20\% de poliacrilamida, y se cargaron $2,5 \mu \mathrm{g}$ de proteínas totales por carril. Tras la electroforesis, el gel fue teñido con azul de Coomassie (apartado 3.8.5). El resultado se muestra en la Figura 4.17; en ella se aprecia que la composición proteica de los viriones recombinantes detectable por este método de tinción es idéntica a la del rNDV-F3aamRFP. No se aprecia ninguna proteína adicional, ni la endoglina ni la quimera EExC/FTMCyt, al tratarse de una técnica de detección menos sensible que el Western-blot. 


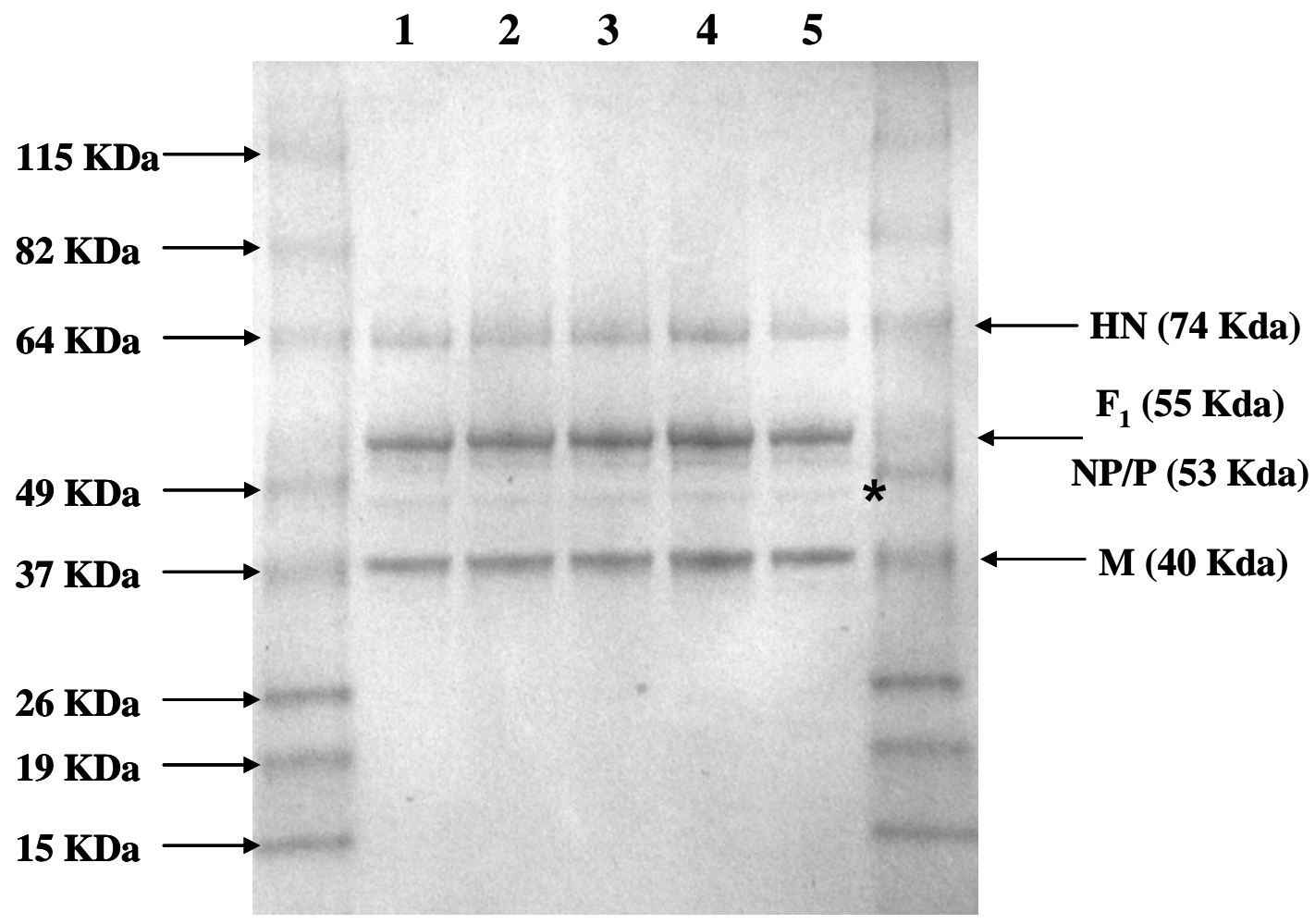

Figura 4.17.- SDS-PAGE de viriones purificados $(2,5 \mu \mathrm{g}$ por carril, gel en gradiente $5-20 \%$ de poliacrilamida) 1.- rNDV-F3aa-mRFP. 2.- rNDV-B1-Endo. 3.- rNDV-F3aa-Endo. 4.- rNDV-B1-EExC/F-TMCyt. 5.- rNDV-F3aa-EExC/FTMCyt. Se indican los pesos moleculares del marcador y las proteínas que corresponden a cada banda. La banda marcada con un asterisco no se corresponde con ninguna proteína estructural del NDV y ha sido identificada como un producto de la degradación de NP (Jain et al., 2009).

\subsection{5.- INFECCIÓN DE CÉLULAS MESANGIALES CON rNDV-F3aa-Endo.}

La posibilidad de utilización de los rNDV recombinantes como vectores de expresión rescatados fue analizada en células mesangiales humanas y de rata. Las células mesangiales del glomérulo de riñón expresan la endoglina de forma natural y su actividad, vinculada al sistema del TGF- $\beta$, interviene en la producción y secreción de matriz extracelular (apartado 1.5.2). La sobreexpresión de endoglina modifica este proceso y fue el indicador que se utilizó para determinar la funcionalidad de la endoglina expresada por rNDV. 


\subsubsection{1.- Infectividad del NDV en células mesangiales y niveles de expresión de endoglina.}

Para determinar si el NDV es capaz de infectar y replicarse en células mesangiales se infectaron tres tipos celulares distintos con rNDV-F3aa-mRFP y rNDVF3aa-Endo. Las células utilizadas fueron la línea celular K18, de células mesangiales humanas inmortalizadas, y cultivos primarios de células mesangiales humanas (CMH) y de rata de raza Wistar-Kyoto (WKY). Las células se sembraron en placas de 12 pocillos y fueron infectadas con los virus a una m.o.i. de 0,2. Transcurridas 24 horas postinfección, se fijaron para inmunofluorescencia (apartado 3.8.1) y se marcaron con el anticuerpo monoclonal anti-endoglina humana P3D1, tal y como se ha descrito anteriormente. Los resultados se muestran en la Figura 4.18: todos los tipos celulares analizados se infectaron tanto con rNDV-F3aa-mRFP como con rNDV-F3aa-Endo, produciendo éste último una sobreexpresión de endoglina humana en las membranas. En ninguno de estos tipos celulares se apreció formación de sincitios originada habitualmente por el rNDV-F3aa en otras líneas celulares.

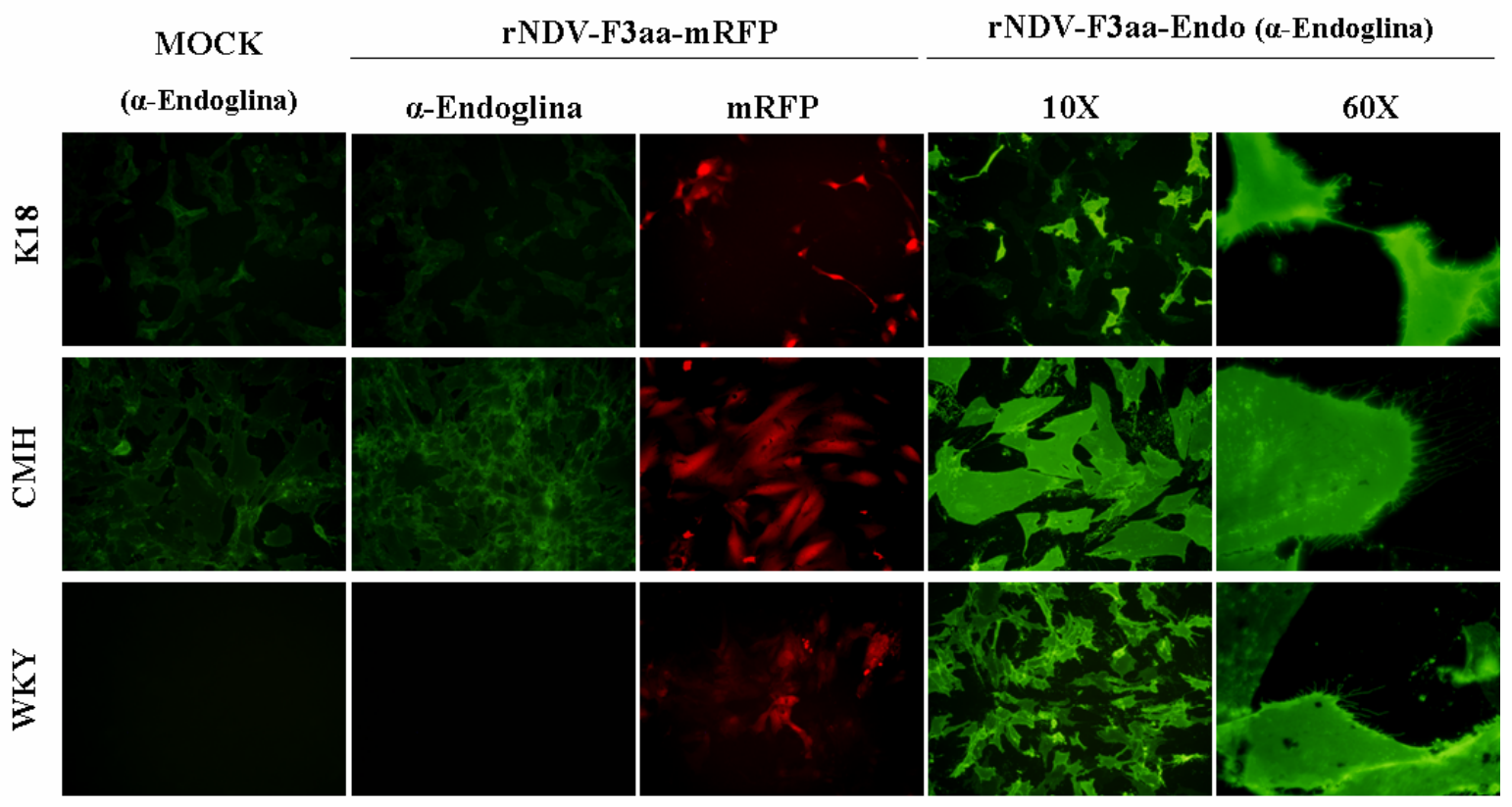

Figura 4.18.- Inmunofluorescencia sobre células mesangiales infectadas con rNDVF3aa-mRFP y rNDV-F3aa-Endo. Células K18, CMH y WKY infectadas a 0,2 m.o.i. con rNDV-F3aa-Endo y rNDV-F3aa-mRFP como control. Las células fueron fijadas a las $24 \mathrm{~h}$ p.i. y marcadas con el anticuerpo P3D1 anti-endoglina para su observación al microscopio de fluorescencia. Las células $\mathrm{K} 18$ y $\mathrm{CMH}$, ambas humanas, mostraron unos niveles basales de expresión de endoglina, si bien muy inferiores a los obtenidos en las células infectadas por rNDV-Endo. Las células de rata WKY expresan constitutivamente endoglina de rata frente a la cual no reacciona el P3D1, por lo que en ellas no se obtuvo ningún fondo 


\subsubsection{2.- Evaluación temporal de la expresión de endoglina en cultivos primarios de células mesangiales.}

Para determinar la evolución temporal de la síntesis de endoglina por las células mesangiales infectadas se llevaron a cabo inmunodetecciones de la misma a distintos tiempos, bien mediante inmunofluorescencia, bien mediante Western-blot. Se emplearon para ello las células mesangiales en cultivo primario, $\mathrm{CMH}$ y WKY, sembradas en placas de 24 o 6 pocillos. Las células se infectaron a una m.o.i. de 1 con rNDV-F3aa-Endo o con rNDV-F3aa-mRFP y transcurridos distintos tiempos fueron procesadas para inmunofluorescencia (apartados anteriores y 3.8.1) o western blot (3.8.2-3.8.4). La detección de endoglina por inmunofluorescencia se llevó a cabo en células sin permeabilizar y utilizando el anticuerpo monoclonal anti-endoglina P3D1 (sobrenadante de hibridoma, dilución 1:2). El western-blot se llevó a cabo en condiciones no reductoras y se utilizó el anticuerpo monoclonal anti-endoglina TEA 1/58-1 (sobrenadante de hibridoma, dilución 1:10), que puede detectar la forma dimérica, no reducida, de la proteína. Los resultados obtenidos con las células WKY y $\mathrm{CMH}$ se muestran en las Figuras 4.19A y 4.19B respectivamente. La expresión de endoglina comienza a ser patente a las $8 \mathrm{~h}$ p.i. en las dos técnicas empleadas, bien aparente a las $12 \mathrm{~h}$ y a las $17 \mathrm{~h}$ ya se obtiene la máxima señal (Fig. 4.19A), que se mantiene hasta las 36 horas sin modificaciones apreciables. A partir de las $36 \mathrm{~h}$ p.i. las células comienzan a mostrar claros efectos citopáticos a consecuencia de la infección (Fig 4.20B): hasta ese momento siempre mostraron un fenotipo normal.

\subsubsection{3.- Síntesis y acumulación de proteínas de la matriz extracelular por células infectadas con rNDV-Endo.}

La funcionalidad de la endoglina expresada por el rNDV-Endo se comprobó atendiendo a una de sus funciones en las células mesangiales: la regulación de la síntesis y acumulación de matriz extracelular, una respuesta a TGF- $\beta$ modulada por la endoglina (Rodríguez-Barbero et al., 2001; Rodríguez-Peña et al., 2001; Díez-Marques et al., 2002). En concreto, analizamos el efecto de la sobreexpresión de la proteína sobre los niveles de fibronectina y colágeno I tanto en las células en cultivo como en su sobrenadante. 


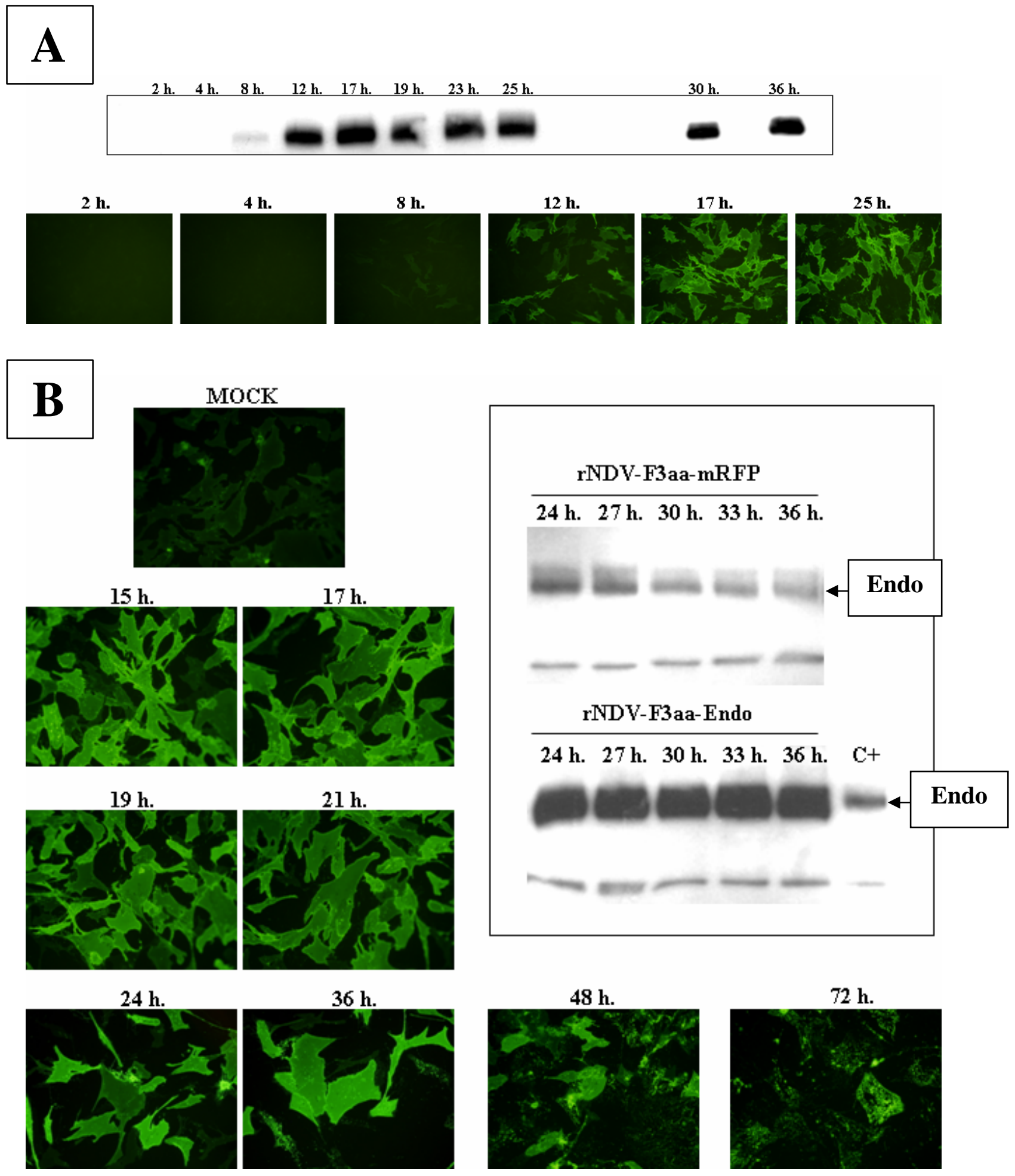

Figura 4.19.- Expresión de endoglina a distintos tiempos en células infectadas. Células en placas de 6 pocillos (para Western-blot) o 24 pocillos (para inmunofluorescencia) fueron infectadas a una m.o.i. de 1 con rNDV-F3aa-Endo o rNDV-F3aa-mRFP y procesadas a distintos tiempos para la detección de endoglina. (A).- Western-blot $(20 \mu \mathrm{g}$ prot. por pocillo) e inmunofluorescencia sobre células WKY. La expresión de endoglina se hace perceptible a las $8 \mathrm{~h}$ y alcanza su máximo en torno a las $17 \mathrm{~h}$. (B).- Western-blot ( $20 \mu \mathrm{g}$ prot. por pocillo) e inmunofluorescencia sobre $\mathrm{CMH}$. Se aprecia la diferencia sobre los niveles de expresión basales propios de las $\mathrm{CMH}$, que se mantiene hasta las 36h. A partir de ese momento las células comienzan a mostrar daños aparentes, visibles en los paneles de $48 \mathrm{~h}$ y $72 \mathrm{~h} .(\mathrm{C}+$ : control positivo, extracto de mioblastos L6E9 con transfección estable de L-endoglina humana) 
Células WKY en placas de $100 \mathrm{~mm}$ en torno a un $90 \%$ de confluencia se infectaron con rNDV-F3aa-Endo o rNDV-F3aa-mRFP a una m.o.i. de 1 como se describe en el apartado 3.8.1. Transcurridas 30h postinfección los extractos celulares fueron recogidos y procesados como se describe en el apartado 3.8.2. A continuación se calculó la concentración de proteínas totales y se llevaron a cabo electroforesis y transferencias Western para la detección de colágeno tipo I, fibronectina y tubulina. Los anticuerpos empleados y sus diluciones se describen en el apartado 3.5.1. El momento de recogida de las muestras se escogió a las 30h p.i. a la vista de los datos de expresión temporal obtenidos anteriormente: a este tiempo las células se encuentran fenotípicamente intactas y han estado expresando altos niveles de endoglina durante al menos $12 \mathrm{~h}$. Las bandas observables en Western-blot fueron cuantificadas mediante el programa Scion Image. Los resultados del experimento se muestran en la Figura 4.20. Tanto para colágeno I como fibronectina la sobreexpresión de endoglina no afectó a la tasa de síntesis y acumulación celular de estos componentes de la matriz de forma significativa; sin embargo, sí se ve incrementada su secreción al medio. También se observa un incremento en la acumulación extracelular de colágeno y fibronectina tras la infección del rNDV-F3aa-mRFP, si bien inferior al producido con rNDV-F3aa-Endo, lo que parece indicar una acción propia del vector bien por su citotoxicidad bien por una posible influencia sobre las redes celulares de señalización que regulan el proceso. 


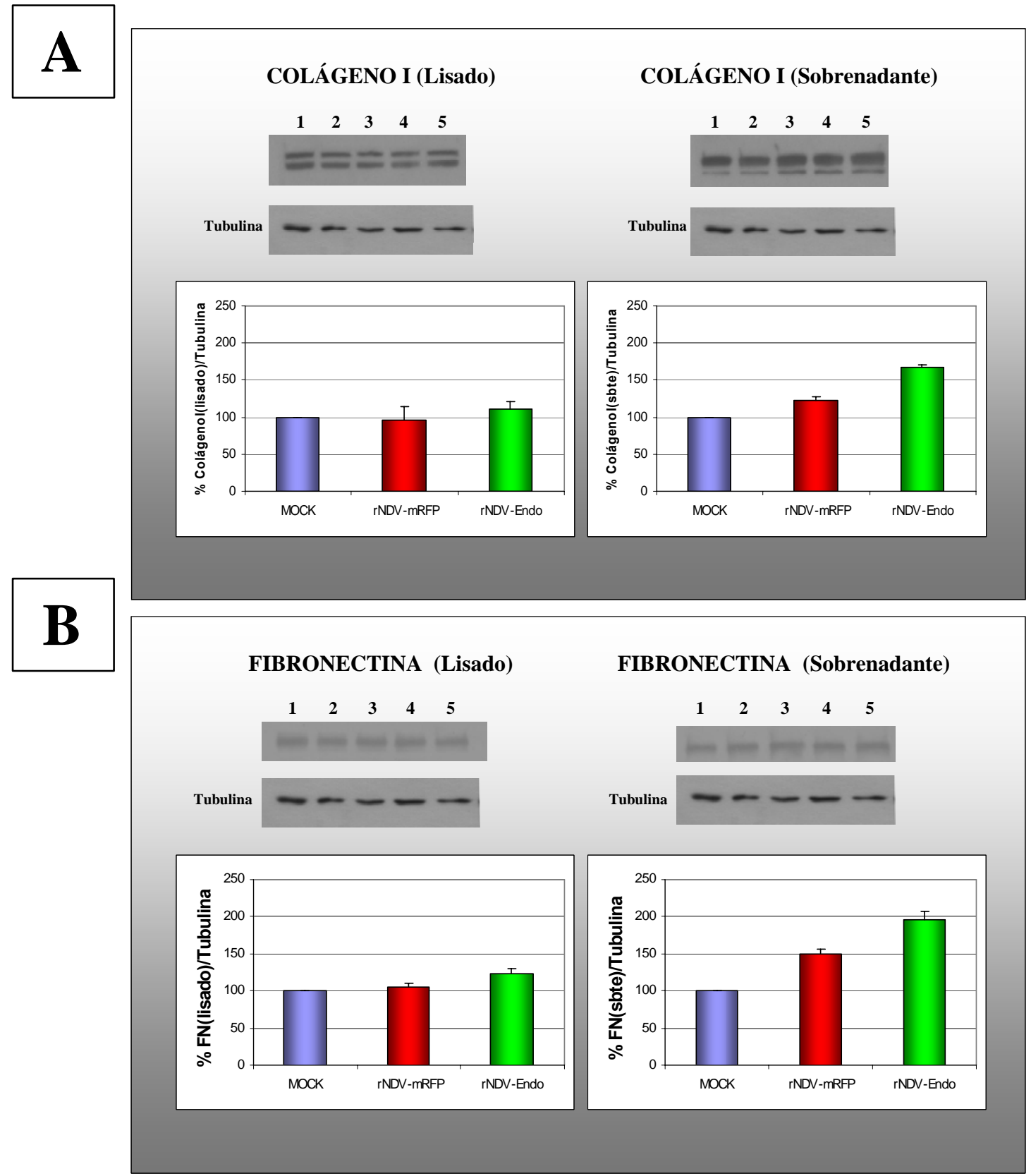

Figura 4.20.- Expresión y acumulación de proteínas de la matriz extracelular tras la sobreexpresión de endoglina llevada a cabo por rNDV. Western-blot realizados a partir de extractos de células WKY obtenidos a las $30 \mathrm{~h}$ p.i. $(20 \mu \mathrm{g}$ de proteínas totales por pocillo). Los carriles numerados indican: 1.- MOCK, 2, 3.- rNDV-F3aa-mRFP; 4,5.- rNDV-F3aa-Endo. (A).- Expresión detectada en el lisado celular y acumulación en el sobrenadante de colágeno I. (B).- Expresión detectada en el lisado celular y acumulación en el sobrenadante de fibronectina. Los resultados indican media y error típico de experimentos roslizodno nor dunlisodo 


\subsection{5.- RELEVANCIA DE LOS RESULTADOS OBTENIDOS.}

Desde que la adaptación de las técnicas de genética inversa a los Mononegavirales permitió el primer rescate de virus de la enfermedad de Newcastle recombinantes (Peeters et al., 1999; Römer-Oberdorfer et al., 1999), se han venido publicando numerosos estudios en los que este virus ha sido modificado con distintos fines. Los aspectos más estudiados han sido los factores que afectan a la virulencia del virus, su posible aplicación como vector de vacunación $y$, más recientemente, su optimización como agente antitumoral (apartado 1.4.2). Este despliegue de actividad investigadora en torno a un virus que, pese a que puede implicar graves pérdidas económicas, no es una amenaza para la salud humana deja de manifiesto la flexibilidad del NDV como herramienta y las múltiples posibilidades que derivan de ella. En el presente trabajo proponemos una nueva opción no considerada hasta este momento: la utilización del NDV como vector de expresión de proteínas no víricas para su estudio funcional y estructural.

Los virus son entidades biológicas especializadas en la multiplicación de su propio genoma en el interior de una célula hospedadora. Son, por tanto, excelentes herramientas naturales para la introducción de genes en un entorno determinado, un aspecto que ha sido determinante en el gran avance que ha tenido la biología moderna. Por otro lado, la capacidad de manipular los genomas, los rangos de hospedador y los factores de virulencia de los virus ha permitido moldearlos como tales herramientas para multitud de usos. El actual catálogo de técnicas de transfección químicas o mecánicas se ve así complementado por otras biológicas que pueden sustituir a las primeras en los casos en que aquellas no sean adecuadas o suficientes. La mayoría de las familias de virus han sido estudiada como vector para la distribución de genes, y la utilización de varios de estos sistemas está plenamente aceptada por la comunidad científica, como son los de adenovirus, herpesvirus, retrovirus, poxvirus o alfavirus (revisado por Lamb y Parks, 2007). La utilización de los paramixovirus como vectores de expresión ha sido, no obstante, más limitada (Kawana-Tachikawa et al., 2002). Sin embargo, por su biología estos virus pueden presentar ventajas como vectores, ventajas que se acentúan en el caso del NDV por el cuerpo de conocimiento acumulado sobre él ya que se lleva 
estudiando como agente antitumoral desde hace más de 40 años. Las ventajas a las que hacemos referencia, básicamente las mismas que convierten al NDV en un buen vector de vacunación (Bukreyev et al., 2006; Huang et al., 2003a, apartado 1.4.2.2) y por las que proponemos este virus como un buen vector de expresión para su uso en un laboratorio son:

(i) Seguridad: como ya se ha dicho, las infecciones por NDV de seres humanos son asintomáticas o leves; carece de fase DNA en su ciclo replicativo, por lo que no tiene capacidad transformante; $y$, pese a cierta controversia reciente ya comentada (apartado1.4.2.2), su nivel natural de recombinación es prácticamente despreciable.

(ii) Simplicidad y versatilidad en su modificación: el genoma modular del NDV y el conocimiento de las secuencias que lo regulan en cis permite la introducción relativamente sencilla del gen foráneo en distintas posiciones; de la misma manera también pueden modificarse el grado de expresión del transgén o la virulencia del propio vector.

(iii) Capacidad y estabilidad: si bien el tamaño de los insertos que pueden introducirse funcionalmente en el NDV es limitado (el máximo son aproximadamente 3.5 Kb, Di Napoli et al., 2007a), únicamente proteínas excepcionalmente grandes quedan excluidas del rango. Los insertos recombinantes han demostrado ser estables durante numerosos pases.

(iv) Propagación y manejo: una vez generados los rNDV su crecimiento hasta títulos muy altos en huevos de gallina es sencillo, al igual que lo son las téncicas precisas para trabajar con el virus. Esta cualidad se complementa con la de seguridad, antes mencionada, para permitir el fácil manejo del NDV en un laboratorio.

(v) Amplio espectro de hospedadores: el NDV infecta la gran mayoría de las células de vertebrados gracias a la ubicuidad de los ácidos siálicos que reconoce como receptores, si bien su nivel de replicación puede variar en función del tipo celular.

(vi) Independencia del ciclo celular para la infección y replicación del virus. Al contrario que otros vectores víricos, como los retrovirus, el NDV es independiente del ciclo celular en las células en las que puede replicarse.

Tomadas en conjunto, estas cualidades permiten que sea fácil y seguro generar, crecer y trabajar con rNDV para expresar una amplia gama de productos en prácticamente cualquier célula de elección. Como inconvenientes, cabe destacar que, al igual que cualquier otro agente transfectante, el NDV produce efectos citotóxicos en la célula infectada, cuyo momento de aparición y severidad varían en función del tipo 
celular. Asimismo, recientemente se ha comenzado a explorar la interacción de proteínas de los paramixovirus con rutas de señalización celulares (Gainey et al., 2008; Sun et al., 2008), lo que podría interferir o enmascarar los estudios del producto recombinante, haciendo más necesaria la cuidada selección de los controles.

Nuestro trabajo ha consistido en la generación de rNDV con el inserto de la Lendoglina humana, una glicoproteína transmembrana a la que se ha relacionado con numerosos fenómenos físiológicos y patológicos (apartado 1.5). Todos los virus que se han rescatado pertenecen a la cepa Hitchner-B1, si bien, además del parental avirulento, se ha usado también el mutante B1/F3aa, que porta una sustitución del sitio de corte proteolítico de la proteína $\mathrm{F}$. Esta modificación le confiere una virulencia mesogénica y le da la capacidad de multiplicarse sin necesidad de proteasas exógenas. Además de la secuencia que codifica la endoglina completa, también hemos construido virus recombinantes con una quimera con el dominio extracelular de endoglina y los transmembrana y citoplasmáticos de la proteína $\mathrm{F}$, ya que ambas son proteínas transmembrana de tipo I. El objeto de estas construcciones es múltiple: (i) disponer de un control negativo adecuado para subsiguientes estudios con endoglina, dado que la ausencia del dominio citoplasmático evitaría su funcionamiento; (ii) forzar una mayor incorporación de la proteína a la membrana de los viriones; y (iii) disponer de un soporte para posibles estudios de la endoglina soluble (sEng), de reciente descripción y que consiste únicamente en la forma extracelular de la proteína.

Los virus rescatados $\mathrm{B} 1$ y F3aa, tanto con las formas nativas como quiméricas de endoglina, han mostrado expresarlas en células en cultivo (Figuras 4.14 y 4.15) y sin modificación alguna en su secuencia. Los altos niveles de expresión detectados permiten postular la utilización de estos virus para la producción de la proteína con vistas a su purificación. Cabe plantearse a partir de este momento la incorporación de una señal a las proteínas recombinantes para facilitar su purificación, y nuestro grupo de investigación ya ha comenzado el trabajo para añadir una cola de histidinas a la secuencia de endoglina. Otra posibilidad para la purificación de la proteína es hacerlo desde los viriones de los virus recombinantes, si éstos incorporan una suficiente cantidad de aquella a sus membranas. En este caso, el sistema de purificación sólo habría de tratar con las seis proteínas estructurales del NDV, facilitando mucho el proceso. Dentro del orden Mononegavirales hay virus que han demostrado una gran 
capacidad de incorporación de los insertos recombinantes que portan (especialmente el VSV, revisado por Bukreyev et al., 2006), y con el NDV nuestro grupo de investigación demostró la incorporación de la proteína HA del virus de la gripe (Nakaya et al., 2001), que podía ser incrementada con la adición del dominio citoplasmático de la $\mathrm{F}$ del propio virus (Park et al., 2006). En el caso de la endoglina codificada por los rNDV, hemos demostrado mediante Western-blot que se incorpora en ciertos niveles a las envolturas y que, como era previsible, las quimeras lo hacen con mayor eficiencia (Figura 4.17). Nuevos estudios serán necesarios para evaluar la viabilidad de la purificación de la endoglina a partir de los viriones.

Otra posibilidad de los rNDV recombinantes rescatados es su utilización como vectores de expresión de L-endoglina para estudios funcionales de la misma. En el presente trabajo hemos demostrado que el NDV puede infectar cultivos primarios de células mesangiales humanas y de rata, que no pueden ser transfectados por medios tradicionales, y hemos realizados un seguimiento temporal de la expresión de endoglina en los mismos (Figuras 4.18 y 4.19). En estas células la endoglina se expresa de forma natural (Quackenbush et al., 1986; Rodríguez-Barbero et al., 2001) y se encuentra sobreexpresada en situaciones de fibrosis y daño renal (Roy-Chaudhury et al., 1997). La endoglina forma parte del sistema de receptores del TGF- $\beta$, y su papel en la regulación de los procesos de síntesis y degradación de matriz extracelular que sucede tanto fisiológica como patológicamente en el glomérulo renal queda por determinar. En el presente trabajo hemos realizado estudios preliminares empleando únicamente uno de los virus rescatados (rNDV-F3aa-Endo) que demuestran que la sobreexpresión de endoglina en células mesangiales causada por la infección produce un incremento en la acumulación extracelular de colágeno y fibronectina. Este resultado está en aparente contradicción con lo hallado en otros tipos celulares (Obreo et al., 2004; RodriguezBarbero et al., 2006); sin embargo se corresponde con lo observado en la linea K18 de células mesangiales tras ser transfectadas (Álvarez-Muñoz, 2008; Lopez-Novoa, comunicación personal). Se desconoce si la sobreexpresión de endoglina en las patologías fibróticas renales es causante de la acumulación patológica de matriz o un mecanismo de retroalimentación que busca corregirla, si bien nuestros datos parecen sugerir lo primero. En cualquier caso, no es objetivo de este trabajo el realizar estudios sobre la endoglina, sino proponer una nueva herramienta para su utilización por aquellos grupos que los realizan. A falta de un análisis sobre el efecto citotóxico del 
NDV en células mesangiales y de su influencia sobre el ciclo celular de las mismas, en este punto hemos mostrado un nuevo vector que puede infectarlas efectivamente, expresando altos niveles de L-endoglina y modificando efectivamente su comportamiento fisiológico. Proponemos este sistema para poder disponer en cultivo celular de un modelo que reproduzca los fenómenos asociados a la sobreexpresión de endoglina, empleando las células en las que naturalmente ocurren esas alteraciones y que no pueden transfectarse con efectividad por otros medios. 
4.2.- Estudio mutacional de la proteína de fusión del NDV 


\subsection{1.- CLONACIÓN DE LAS ORF DE LAS PROTEÍNAS HN Y F DEL NDV/HITCHNER B1. MUTAGÉNESIS DE $F$.}

\subsubsection{1.- Amplificación de las secuencias $\mathrm{HN}$ y F por PCR.}

El plásmido pNDV-B1 fue utilizado como molde para la amplificación por la reacción en cadena de la polimerasa (PCR) de los genes de las proteínas F y HN. El objetivo final era introducirlos en el vector de expresión pCAGGs, por lo que en el diseño de los cebadores se introdujeron dos nuevos sitios de restricción ClaI (en 5') y BglIII (en 3', ver Tabla 3.1.B). La PCR se realizó según las condiciones descritas previamente, y tras comprobar la presencia de los fragmentos deseados en un gel de agarosa (Figura 4.21.A), éstos fueron purificados directamente del mismo.

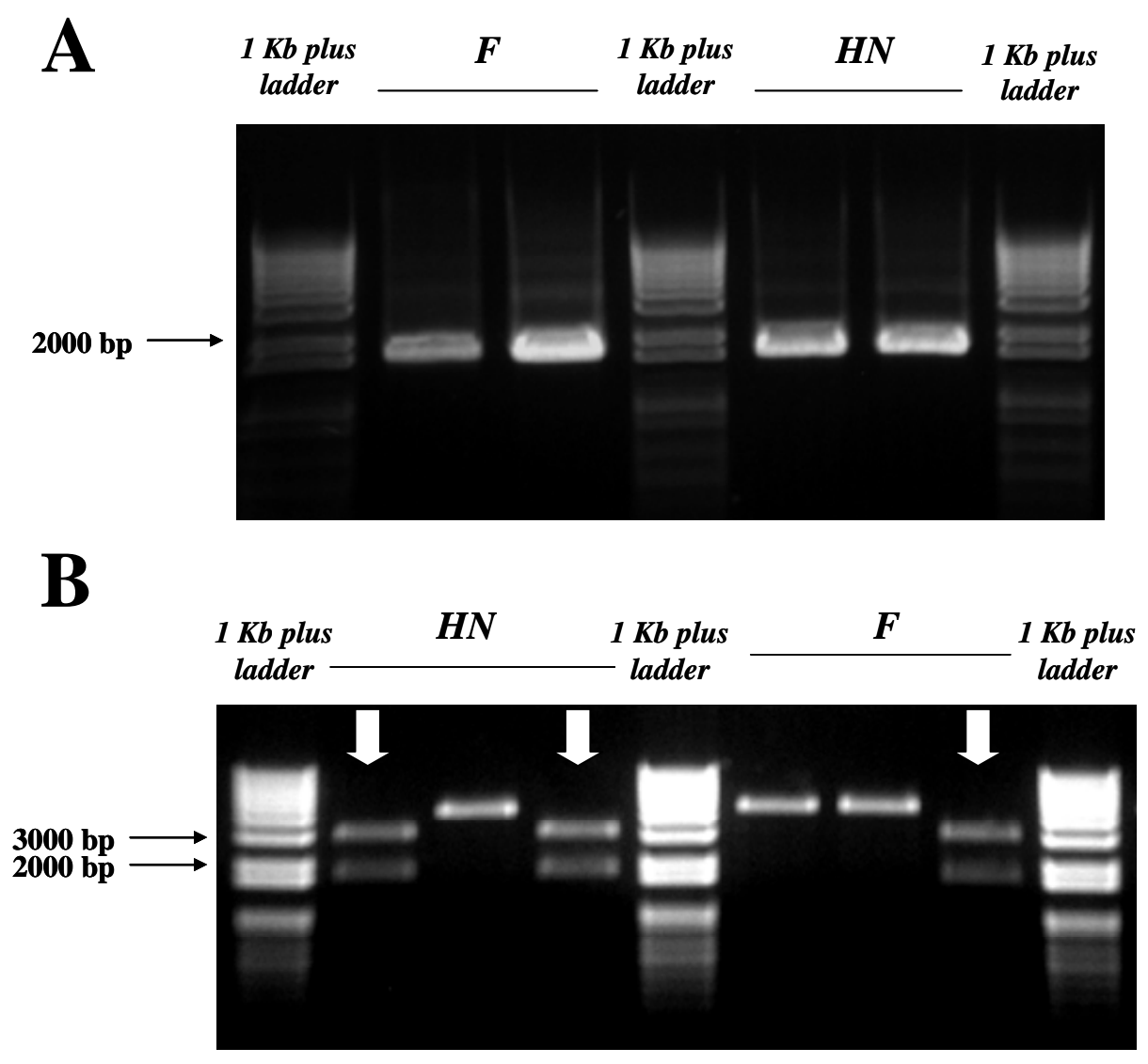

Figura 4.21.- Clonación de $\boldsymbol{F}$ y $\boldsymbol{H}$ en pGEM-T. Electroforesis en geles de agarosa al 0.8\%. (A).- PCR sobre pNDV-B1 para la amplificación de los fragmentos $F$ (1685 pares de bases) y $H N$ (1758). (B).- Digestión con ClaI/BglIII de clones obtenidos de pGEM-HN y pGEM-F. Las flechas marcan los patrones de digestión correctos. 


\subsubsection{2.- Clonación de F y HN en pGEM-T.}

Los fragmentos $F$ y $H N$ amplificados por PCR fueron clonados en pGEM-T dado que la posterior subclonación en pCAGGs resulta más fácil a partir de este intermediario. Además, la construcción final pCAGGs-F iba a ser demasiado grande para poder hacer eficientemente mutagénesis sobre ella, mientras que pGEM-F sí sería un soporte adecuado. La clonación se llevó a cabo como se describe en el apartado 3.6.12. Las colonias se seleccionaron en primera instancia por su color, gracias al sistema $X$-Gal, y posteriormente fueron crecidas y analizadas por digestión con las endonucleasas ClaI y BglIII para comprobar la presencia del inserto (Fig. 4.21B). Varios clones positivos se secuenciaron para comprobar la fidelidad del proceso. El único cambio descubierto con respecto a la secuencia de pNDV-B1 remitida a GenBank fue una sustitución en la posición 81 de la ORF de $\mathrm{F}$ ( $t$ por $c$ ), que no afecta a la secuencia de aminoácidos.

\subsubsection{3.- Mutagénesis dirigida de la proteína $F$.}

Decidimos mutar varios residuos de la proteína F del NDV basándonos en la información cristalográfica publicada sobre la misma (Chen et al., 2001) y sobre la proteína F del virus parainfluenza 5 (PIV5), un paramixovirus muy similar al NDV (Yin et al., 2006). Los residuos a mutar se encuentran en regiones del tallo y la cabeza de la proteína, como se esquematiza en la Figura 4.22.

En la conformación prefusogénica de la proteína de fusión de los paramixovirus la región HRA aparece empaquetada en la cabeza de la proteína, formando parte del dominio DIII (Yin et al., 2006, apartado 1.3.2.). HRA aparece subdividida en 11 segmentos, constituyendo en su conjunto el resorte que al activarse la fusión "dispara" el péptido de fusión hasta la membrana diana. Por todo ello, los cambios conformacionales de HRA durante la fusión son profundos y su estructura en la forma posfusogénica de la proteína es radicalmente distinta a la de la forma prefusogénica (Chen et al., 2001; Yin et al., 2005). El dominio más C-terminal de HRA, llamado h4 por Yin y colaboradores, permanece como una $\alpha$-hélice tanto en la estructura prefusogénica como posfusogénica, y en ambas permanece en la proximidad de la heptada repetida $\mathrm{HRC}$ de la subunidad $\mathrm{F}_{2}$. En la estructura posfusogénica de la proteína F del NDV, las cadenas laterales de los residuos Q204, V211 y N211 de h4 forman una 
1 F2

A

DI $\quad$ DIII

DIII

DI

DII \begin{tabular}{l|l|l|} 
HRB & TM & \\
\hline
\end{tabular}

CONECTOR HRB

B

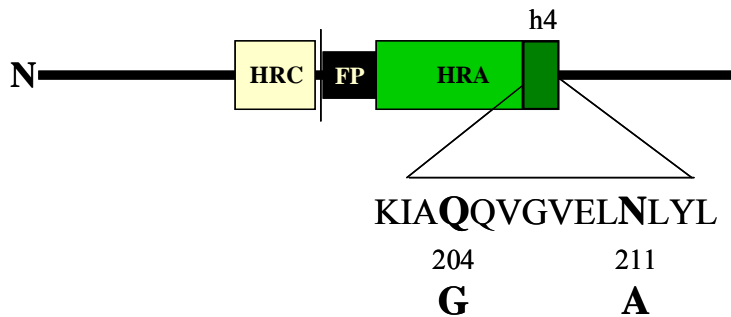

HRB

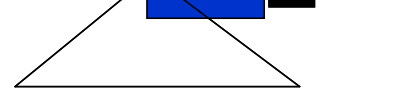

QDSQVIITGNLDISTEL

$454 \quad 461 \quad 463$

A $\quad \mathbf{A} / \mathbf{F ~} \mathbf{A} / \mathbf{F}$

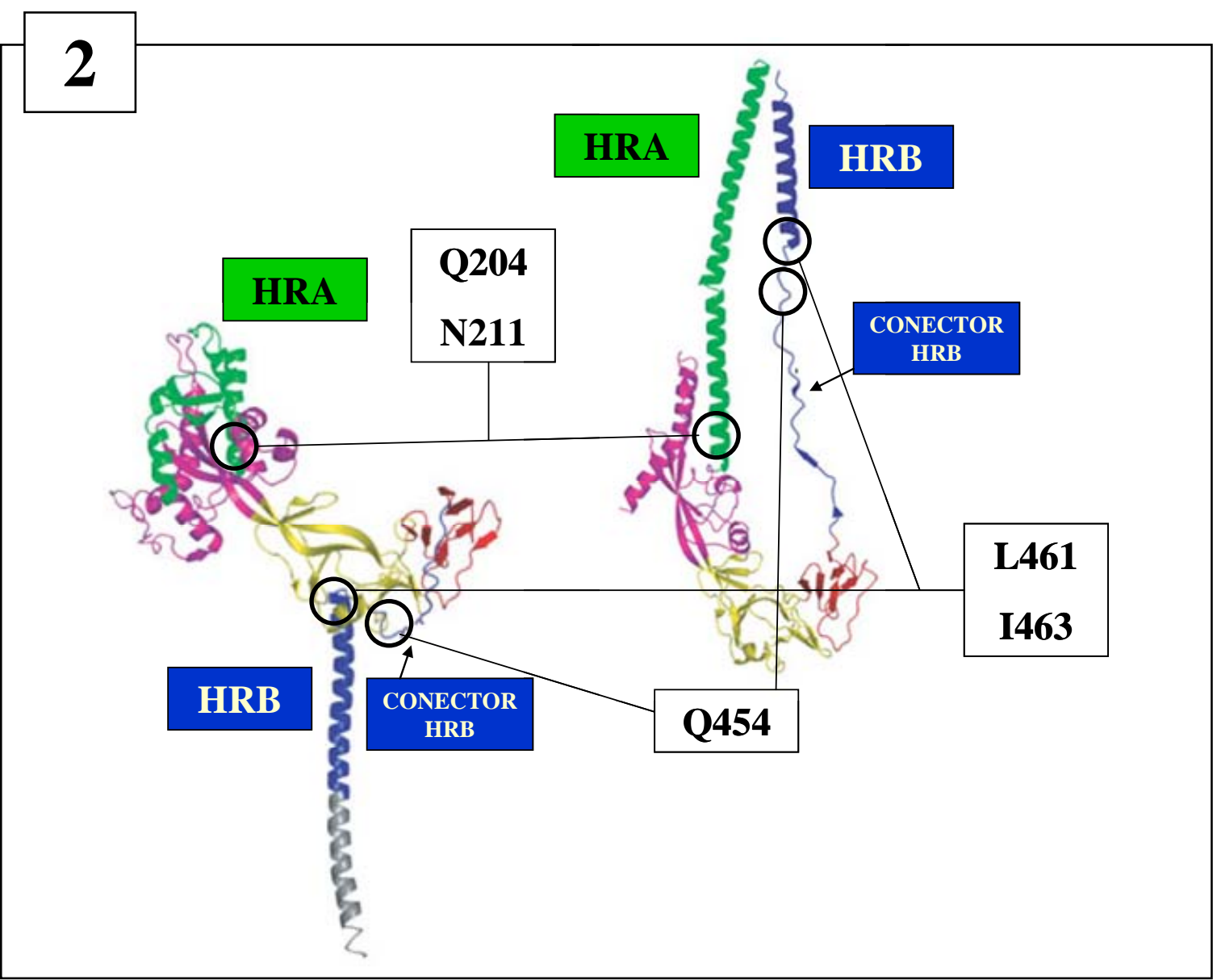

Figura 4.22.- Localización de las mutaciones en la proteína F. 1.-(A): Dominios en la estructura primaria de la proteína F (Yin et al., 2006 y apartado 1.3). (B): Localización de las regiones heptad repeat, el péptido de fusión y las secuencias objeto del presente estudio. Los residuos sustituidos por mutagénesis se muestran en negrita, con sus sustitutos bajo ellos. 2.- Localización de los residuos mutados en la estructura terciaria de la proteína $\mathrm{F}$, en su conformación prefusogénica (izquierda) y postfusogénica (derecha). Se han conservado los patrones de color de 1. (Adaptado de Yin et al., 2006) 
cavidad en el cristal de función desconocida (Chen et al., 2001). Además, los residuos A190 y N197 del PIV5, correspondientes a Q204 y N211 del NDV, se encuentran en posiciones $d$ de la heptada repetida HRA. Para analizar la importancia de estos residuos decidimos sustituirlos por G y A, respectivamente. Estos cambios modifican el tamaño y la polaridad de los residuos, alterando patrón de la heptada.

Otra región de interés descrita en la estructura prefusogénica del virus PIV5 es el conector que une el dominio DII con el tallo de la proteína formado por la región HRB, el llamado conector HRB. En la conformación posfusogénica de la proteína F de NDV los residuos Q445-Q454 de dicho conector emergen de la región del cuello y se insertan en el surco formado por HRA bajo el extremo N-terminal de HRC (Chen et al., 2001). El residuo Q454 fue sustituido por A para analizar la función de esta región.

En el extremo N-terminal de HRB, en la intersección cabeza-tallo de la forma prefusogénica de la proteína, se han descrito dos aminoácidos de gran importancia para la funcionalidad de F en el PIV5 (Russell et al., 2003). Estos residuos, L447 e I449, mostraron jugar un papel relevante tanto en la activación de la fusión como en la estabilidad de la forma posfusogénica. Decidimos mutar los aminoácidos correspondientes en la proteína de fusión del NDV, L461 e I463, a alanina (A) y fenilalanina $(\mathrm{F})$ para comprobar la importancia de dicha región en otros paramixovirus.

La mutagénesis en la secuencia de la proteína F del NDV/Hitchner B1 se realizó como se describe en el apartado 3.6.15. Los oligonucleótidos se diseñaron de forma que introdujeran una marca de restricción que caracterizara el mutante recién generado al mismo tiempo que la sustitución aminoacídica (Tabla 3.2). La mutagénesis se llevó a cabo en el plásmido pGEM-F. Los clones obtenidos para cada mutante fueron comprobados en primer lugar por digestión con endonucleasas (Figura 4.23) y a continuación se secuenciaron para asegurar la presencia de la mutación deseada.

(Página siguiente) Figura 4.23.- Análisis de restricción de los plásmidos mutados. Se indican los nuevos sitios de reconocimiento para enzimas de restricción introducidos para cada mutante (con un asterisco, si el sitio se ha añadido, o con K.O. si se ha quitado), los sitios de corte para la misma enzima ya presentes en pGEM-F y el patrón de digestión esperable. A la derecha se muestran geles de agarosa al $0.8 \%$ con las digestiones realizadas durante el análisis. Los clones con un patrón de digestión positivo se indican con una flecha blanca. 

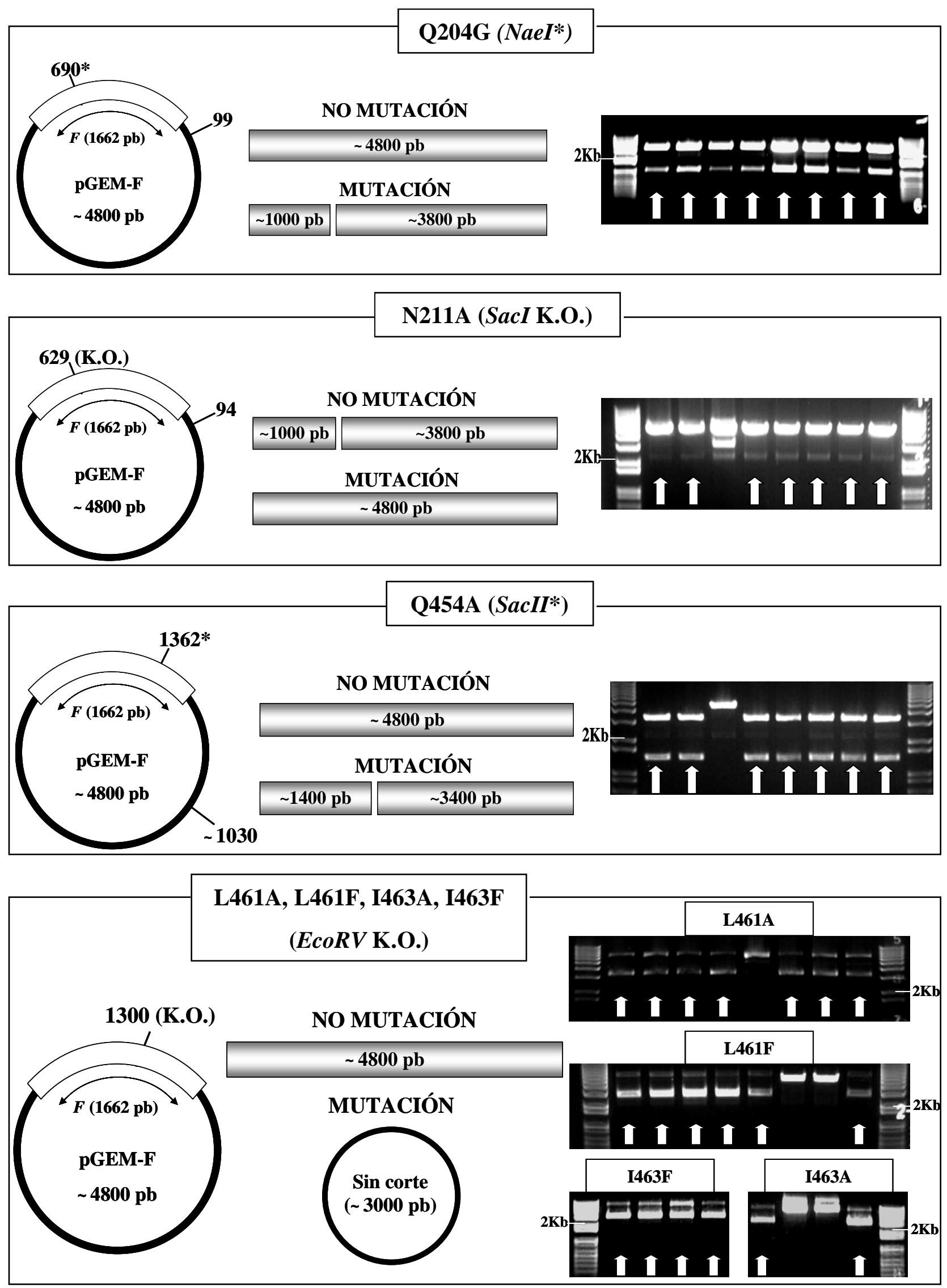


\subsubsection{4.- Clonación de F y HN en pCAGGs.}

Una vez comprobada la presencia de las mutaciones deseadas en pGEM-F, tanto los plásmidos mutados como pGEM-Fwt y pGEM-HN fueron digeridos con las enzimas ClaI y BglIII para subclonar los fragmentos codificantes de las proteínas en el vector pCAGGs. El vector empleado como receptor fue pCAGGs-mRFP, que a su vez también fue digerido con ClaI/BglIII para extraer el inserto mRFP preexistente. La banda correspondiente al vector linealizado se aisló por purificación desde un gel de agarosa, se desfosforiló por acción de la fosfatasa alcalina (CIP) y se empleó para las clonaciones de F y HN como se describe en el apartado 3.6.11. Los clones obtenidos fueron seleccionados por PCR con los cebadores pCAGGs-5'-F/Sec/rev (para F) y pCAGGs5'-HN/Sec/rev (para HN, ver Tabla 3.3), y comprobados por digestión con ClaI/BglIII (Figura 4.24). Finalmente, tras ser convenientemente amplificados en E.coli, los clones elegidos se secuenciaron para asegurar la integridad del inserto.

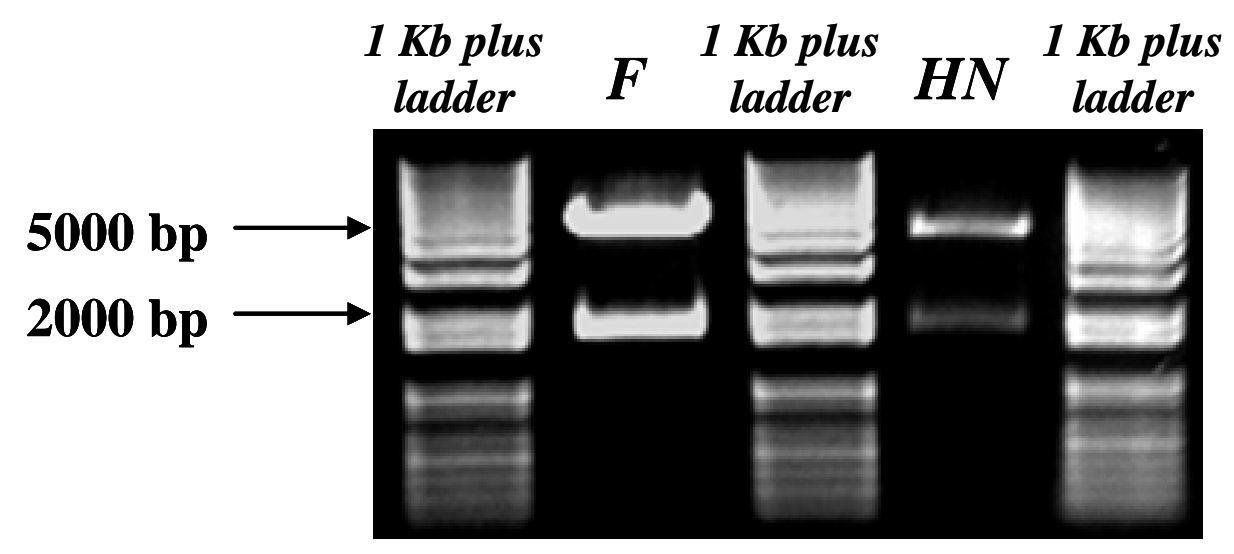

Figura 4.24.- Digestión de pCAGGs-Fwt y pCAGGs-HN con ClaI/BglIII. Los tamaños de los fragmentos, considerando las adiciones realizadas en la PCR, son los siguientes: F, $1670 \mathrm{pb} ; \mathrm{HN}, 1743 \mathrm{pb}$; pCAGGs, 4696 pb. 


\subsection{2.- ANÁLISIS DE LOS MUTANTES DE LA PROTEÍNA F DEL NDV.}

\subsubsection{1.- Determinación de la expresión de las proteínas mutantes en la superficie celular.}

La cuantificación de la expresión de los distintos mutantes de la proteína $\mathrm{F}$ del NDV se llevó a cabo mediante citometría de flujo. Se transfectaron a tal efecto células HeLa con los distintos pCAGGs construidos, y transcurridas 24 horas las células se trataron para su estudio en el citómetro tal y como se describe en el apartado 3.8.6. Los resultados se obtuvieron como densitogramas y se analizaron con el programa WinMDI para obtener los parámetros que definieran los distintos mutantes: la intensidad media de fluorescencia de las células transfectadas (Gmean) y el \% de células consideradas positivas (ver Figura 3.9).

En el análisis se emplearon los dos anticuerpos que nuestro grupo de investigación dispone para reconocer la proteína F del NDV: un suero policlonal contra todas las proteínas del NDV y un anticuerpo monoclonal específico contra $\mathrm{F}$, denominado 2A6. Los resultados obtenidos a partir de experimentos realizados por triplicado para cada mutante se muestran en la Tabla 4.1 y la Figura 4.25.

TABLA 4.1. Expresión en superficie de los distintos mutantes y reactividad con mAb $2 A 6$

\begin{tabular}{lcc}
\multicolumn{2}{c}{ \% respecto al tipo silvestre * } \\
\hline Q204G & pAb & mAb 2A6 \\
N211A & $102,603 \pm 34,5$ & $96,738 \pm 20,2$ \\
Q454A & $186,559 \pm 41,1$ & $65,152 \pm 19,7$ \\
L461A & $97,364 \pm 29,6$ & $83,899 \pm 20,7$ \\
L461F & $126,213 \pm 21,0$ & $93,409 \pm 12,2$ \\
I463A & $101,261 \pm 28,1$ & $98,869 \pm 23,6$ \\
1463F & $167,048 \pm 8,6$ & $42,111 \pm 10,1$ \\
\end{tabular}

* Los valores se obtuvieron considerando como positivos los eventos con mayor señal que el fondo (ver Figura 3.9). El porcentaje de los mismos y la intensidad media de esa población (Gmean) se multiplicaron para obtener un único valor representativo y se refirió al valor obtenido con el tipo silvestre, considerado el $100 \%$. 

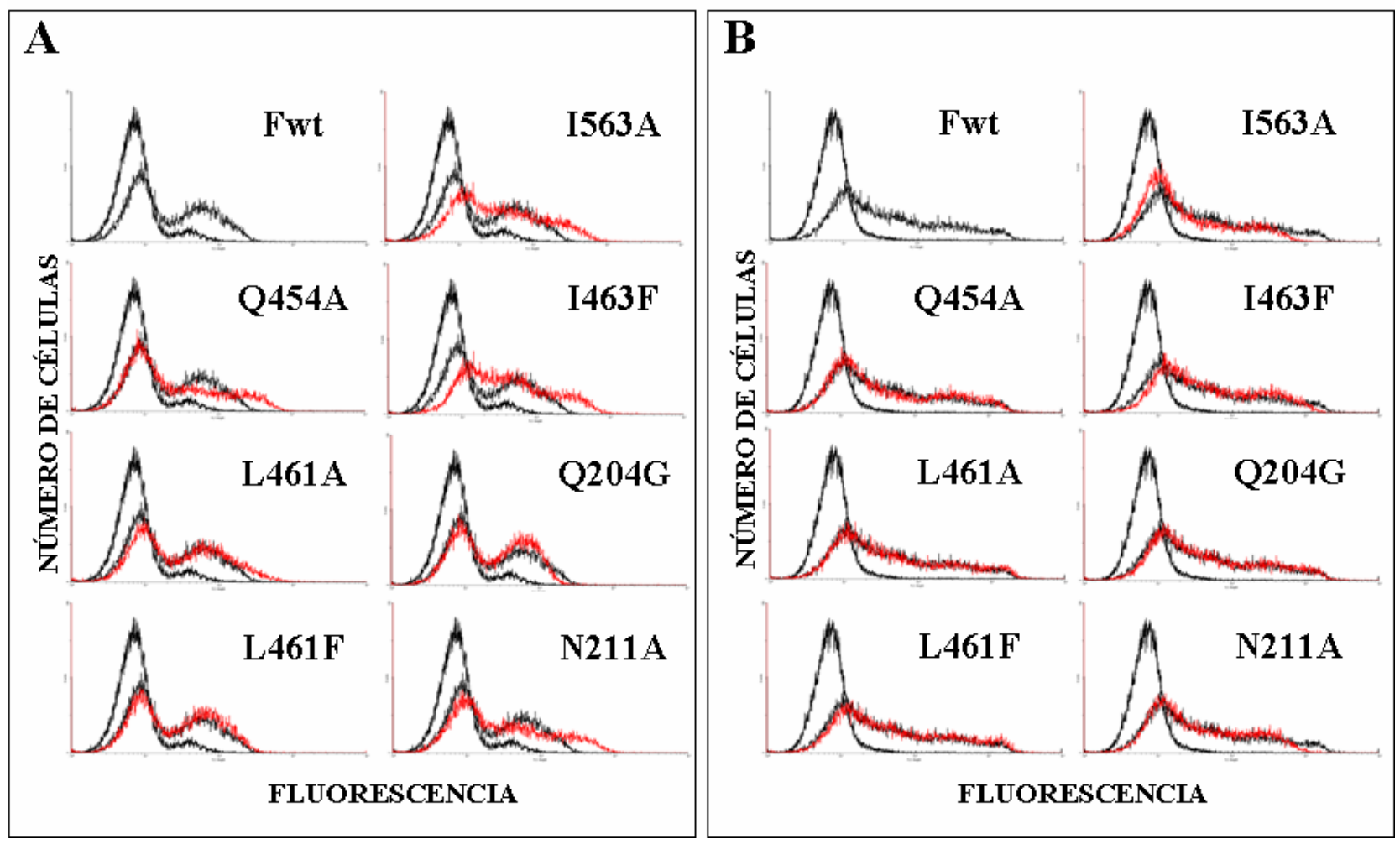

Figura 4.25. Análisis de la expresión en la superficie celular de las proteínas $\mathbf{F}$ mutantes mediante citometría de flujo. Se muestran histogramas representativos del análisis por citometría de flujo de la expresión de los mutantes de F, usando como anticuerpo primario el suero policlonal $\alpha$-NDV (panel A) o el anticuerpo monoclonal 2A6 (panel B). En cada panel se muestran el fondo de cada experimento, los resultados obtenidos con Fwt (línea negra) y con cada uno de los mutantes (línea roja).

Paralelamente a los estudios de citometría de flujo se analizó de forma cualitativa la expresión de los mutantes mediante inmunofluorescencia (Figura 4.26). En ambos casos los resultados obtenidos están en consonancia, si bien difirieron entre las distintas proteínas en función del anticuerpo empleado. Los mutantes Q454A, L461A, L461F y Q204G mostraron niveles de expresión similares a los del tipo silvestre Fwt con ambos anticuerpos, dando mayor señal con el anticuerpo monoclonal que con el policlonal. Los otros tres mutantes estudiados (I463A, I463F y N211A) reaccionaron preferentemente con el anticuerpo policlonal, lo que en apariencia indicaría una expresión en superficie significativamente mayor que la de Fwt. Sin embargo, los resultados con estas mismas proteínas fueron los opuestos al detectarse con el anticuerpo monoclonal: su reactividad con el 2A6 fue menor que en el caso del tipo silvestre. A la vista de estos resultados, el anticuerpo monoclonal 2A6 podría estar 
detectando una conformación específica propia del tipo silvestre: si ello fuera así Q454A, L461A, L461F y Q204G se estarían expresando a los mismos niveles que Fwt mientras que I463A, I463F y N211A lo harían en mayor cantidad (un 42\%, 78\% y 65\%, respectivamente), si bien adoptando una conformación distinta. El anticuerpo 2A6 podría detectar un epítopo en el tipo silvestre que en la conformación de los otros tres mutantes no apareciera tan expuesto o que hubiera cambiado lo suficiente como para alterar su reactividad con el anticuerpo. Otro dato que apoya la hipótesis de que el anticuerpo $2 \mathrm{~A} 6$ es dependiente de la conformación exacta de un epítopo concreto es el hecho de que no pueda unirse a Fwt ni en western-blot ni en inmunoprecipitación (datos no mostrados). Por otra parte, el mismo cambio que en I463A, I463F y N211A dificulta el reconocimiento por el anticuerpo monoclonal podría facilitar su reconocimiento por parte del cóctel de anticuerpos presente en el suero policlonal, sesgando los resultados de su expresión. En cualquier caso, tanto los estudios de citometría de flujo como los de inmunofluorescencia indican que todas las proteínas mutantes se expresan en la superficie de células transfectadas. Al carecer de un anticuerpo adecuado para inmunoprecipitación, no se pudo analizar si en los mutantes el precursor $\mathrm{F}_{0}$ era correctamente procesado. 


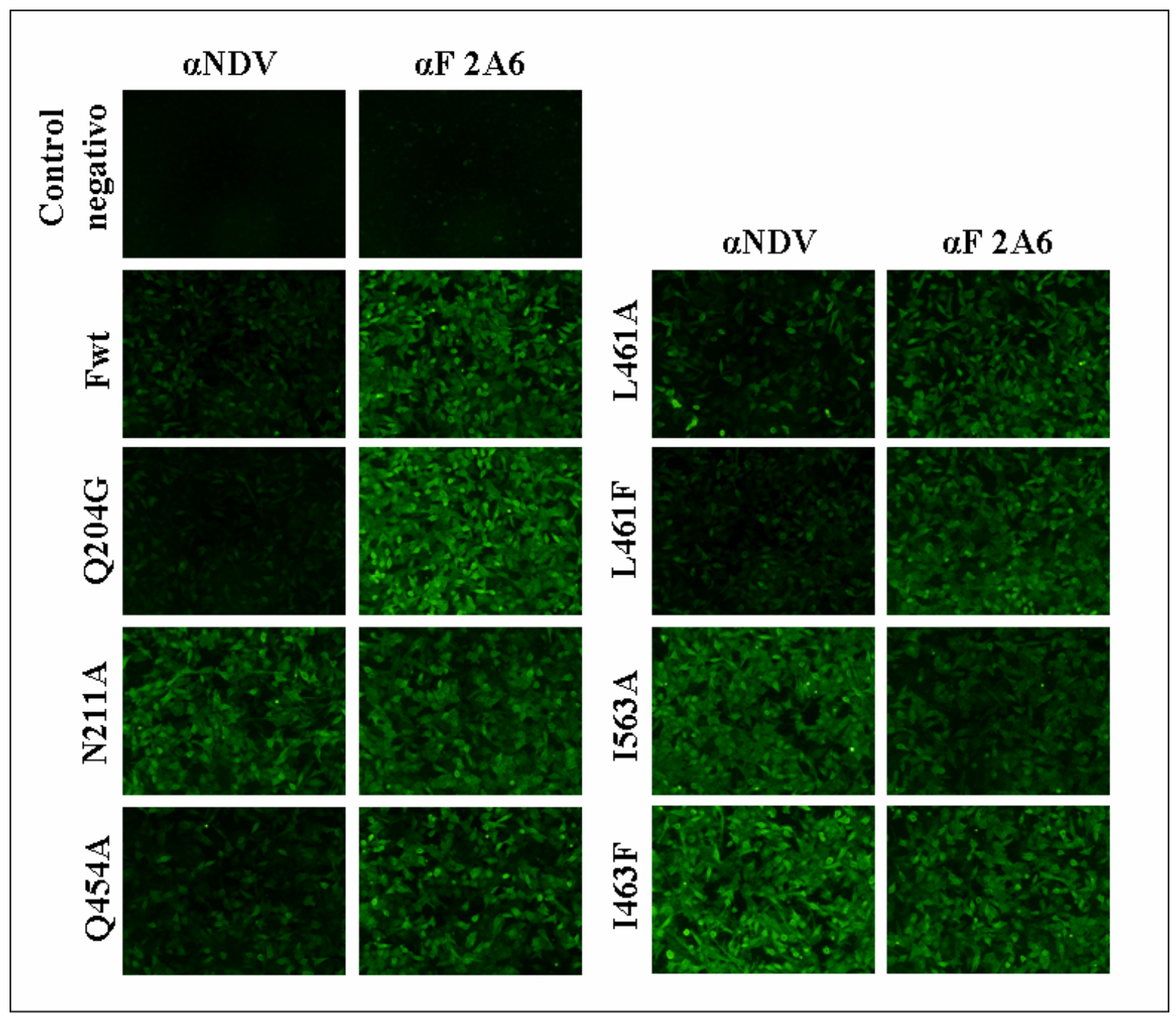

Figura 4.26. Expresión de las proteínas mutantes detectada por inmunofluorescencia. La inmunofluorescencia se realizó en células HeLa transfectadas con los plásmidos codificando las distintas proteínas $\mathrm{F}$ mutantes. Al igual que en los análisis por citometría de flujo se emplearon tanto el suero policlonal $\alpha$ NDV como el anticuerpo monoclonal $\alpha \mathrm{F} 2 \mathrm{~A} 6$. Las células que aquí se muestran no fueron permeabilizadas y por tanto se aprecia la expresión en la membrana plasmática. En células permeabilizadas los resultados fueron similares (datos no mostrados). Todas las micrografías se tomaron bajo la misma exposición con un objetivo 10X. 


\subsubsection{2.- Efecto de las mutaciones de la proteína $F$ en la fusión célula-célula.}

La proteína de fusión del NDV, al coexpresarse en la membrana de células eucariotas junto a su proteína HN homotípica, puede promover la fusión de membranas entre la célula que la expresa (célula efectora) y otra con la que entre en contacto (célula diana). Esta propiedad se utilizó para el estudio del efecto de las mutaciones en la proteína $\mathrm{F}$, empleando dos tipos de ensayo para ello: uno cualitativo, basado en la formación de sincitios, y otro cuantitativo basado en la transferencia de sonda entre células efectoras y dianas.

Analizamos la capacidad de los distintos mutantes para promover la fusión célula-célula de forma cualitativa siguiendo la aparición de sincitios en células transfectadas. Estos ensayos se llevaron a cabo tal y como se describe en el apartado 3.9.2 de Material y Métodos. Se usaron dos líneas celulares diferentes: HeLa, por tratarse de la línea celular usada en el resto de los experimentos del presente trabajo; y BHK-21, por haber sido utilizada en un gran número de publicaciones referentes a la proteína de fusión en paramixovirus y porque se han descrito casos en los que el mismo mutante ha mostrado distinto funcionamiento en distintas líneas celulares (Sergel et al., 2000; Li et al., 2005).

Todos los mutantes analizados, excepto Q454A, promovieron la formación de sincitios al ser coexpresados con la proteína HN en ambas líneas celulares (Figura 4.27). Cinco de las mutaciones, N211A, L461A, L461F, I463A e I463F, incrementaron sustancialmente la formación de sincitios con respecto al tipo silvestre Fwt. El mutante Q204G produjo un fenotipo similar al del tipo silvestre. Al analizar la formación de sincitios en ausencia de $\mathrm{HN}$ se apreció que los mutantes hiperfusogénicos N211A, I463A e I463F también eran capaces de promover la fusión célula-célula sin necesidad de $\mathrm{HN}$, y a unos niveles aún mayores que Fwt+HN (Figura 4.27). Este mismo resultado se obtuvo al coexpresar los mutantes con la proteína HA del virus de la gripe (datos no motrados). En ningún caso se observaron sincitios cuando el precursor $F_{0}$ no fue activado proteolíticamente mediante la adición al medio de cultivo de acetiltripsina (datos no mostrados), lo que era esperable, pues ninguna mutación afectaba a la secuencia de corte de la proteína. 


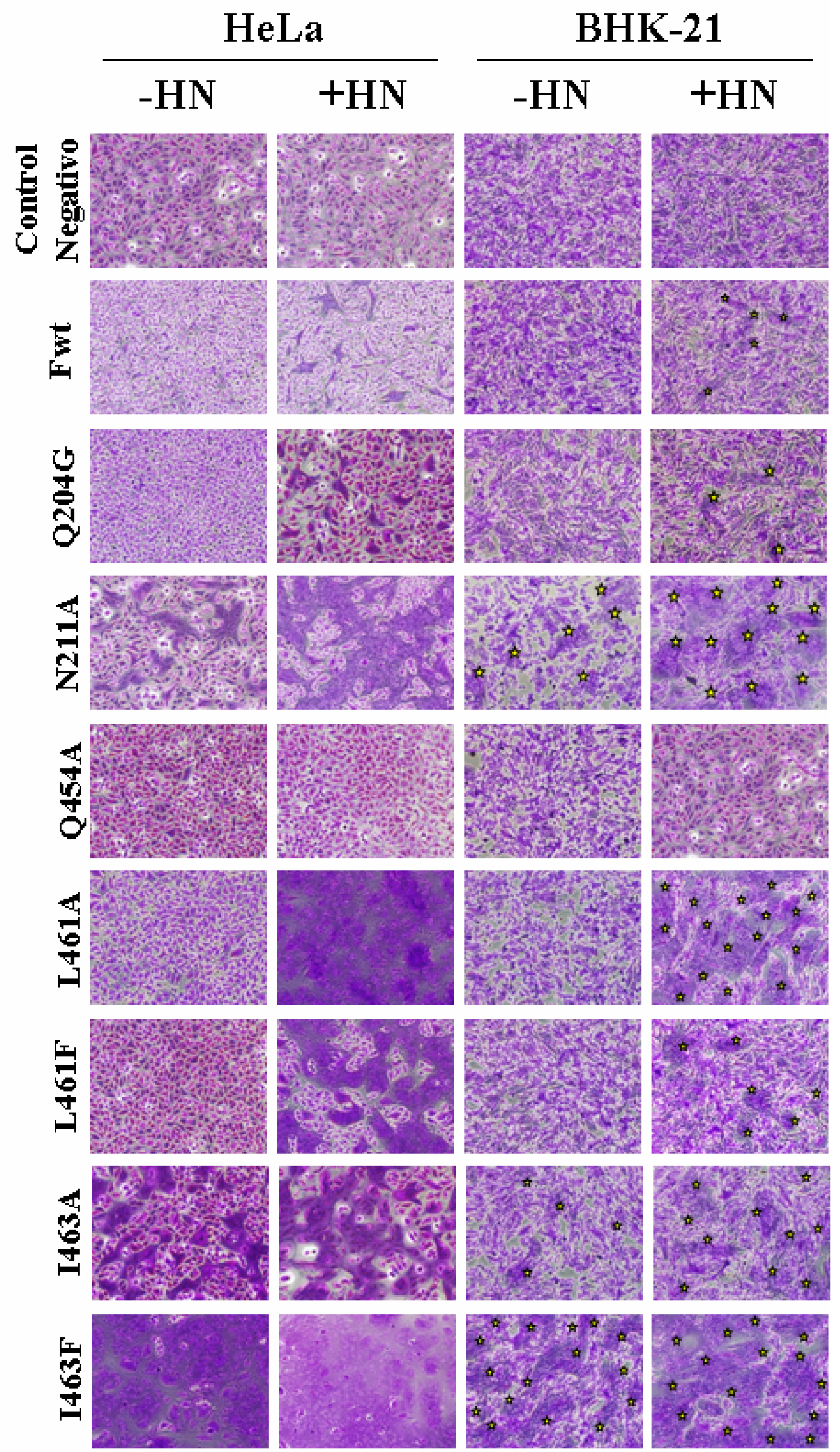


(Página anterior) Figura 4.27. Ensayo de formación de sincitios para el análisis de la fusión célula-célula. Células HeLa y BHK expresando el tipo silvestre o los mutantes de $\mathrm{F}$, en presencia o ausencia de $\mathrm{HN}$, fueron tratadas con acetiltripsina para la activación del precursor $\mathrm{F}_{0}$. Tres horas después, las células se fijaron y tiñeron con cristal violeta. Se muestran micrografías de campos representativos (10X). Los sincitios menos aparentes en las BHK-21 se señalan con estrellas para facilitar su identificación.

La cuantificación de la fusión célula-célula se llevó a cabo por medio de ensayos de transferencia de sonda (apartado 3.9.3), coexpresando los mutantes con la proteína $\mathrm{HN}$ y añadiendo posteriormente sobre las células transfectadas eritrocitos doblemente marcados con dos sondas fluorescentes. Estos ensayos confirmaron los datos obtenidos mediante el método de los sincitios, como se observa en la Figura 4.28. El mutante Q454A no produjo ninguna fusión apreciable: no pudo promover la transferencia ni de la sonda lipofílica R18 (indicadora de la mezcla de lípidos de la membrana) ni de la sonda hidrosoluble calceína (indicadora de mezcla de contenidos). El mutante Q204G, cuyos datos de expresión eran similares a los del tipo silvestre, promovió niveles de fusión algo inferiores a los de éste. N211A y los mutantes en L461 e I463 resultaron ser más fusogénicos que Fwt, sin diferencias entre mezcla de lípidos y de contenidos. El incremento en la fusión fue mayor cuando L461 fue sustituido por el aminoácido alifático alanina (L461A) en comparación con la sustitución por el aromático fenilalanina (L461F). Por el contrario, I463F fue más fusogénico que I463A; de hecho, I463F se mostró como el mutante más fusogénico de todos los analizados.

Atendiendo a los resultados obtenidos mediante citometría de flujo con el suero policlonal anti-NDV, los mutantes N211A, I463A e I463F tenían mayores valores de expresión en la superficie celular. Otros estudios han descrito que la fusión célula-célula es directamente dependiente de la cantidad de proteína de fusión expresada en la superficie celular (Dutch et al., 1998), por lo que quisimos comprobar si los niveles de fusión mostrados por estos mutantes eran debidos a mayores niveles de expresión. Para ello, se realizaron nuevos ensayos de transferencia de sonda disminuyendo la cantidad de DNA transfectado para disminuir la expresión de la proteína F. Como control se cuantificó tanto la expresión de mRFP como la transferencia de sonda inducida por Fwt a las mismas cantidades decrecientes de DNA. Los resultados de estos experimentos se muestran en la Figura 4.29: los niveles de transferencia de sondas para los mutantes 
siguieron siendo mayores que en el tipo silvestre con las distintas concentraciones de DNA empleadas.
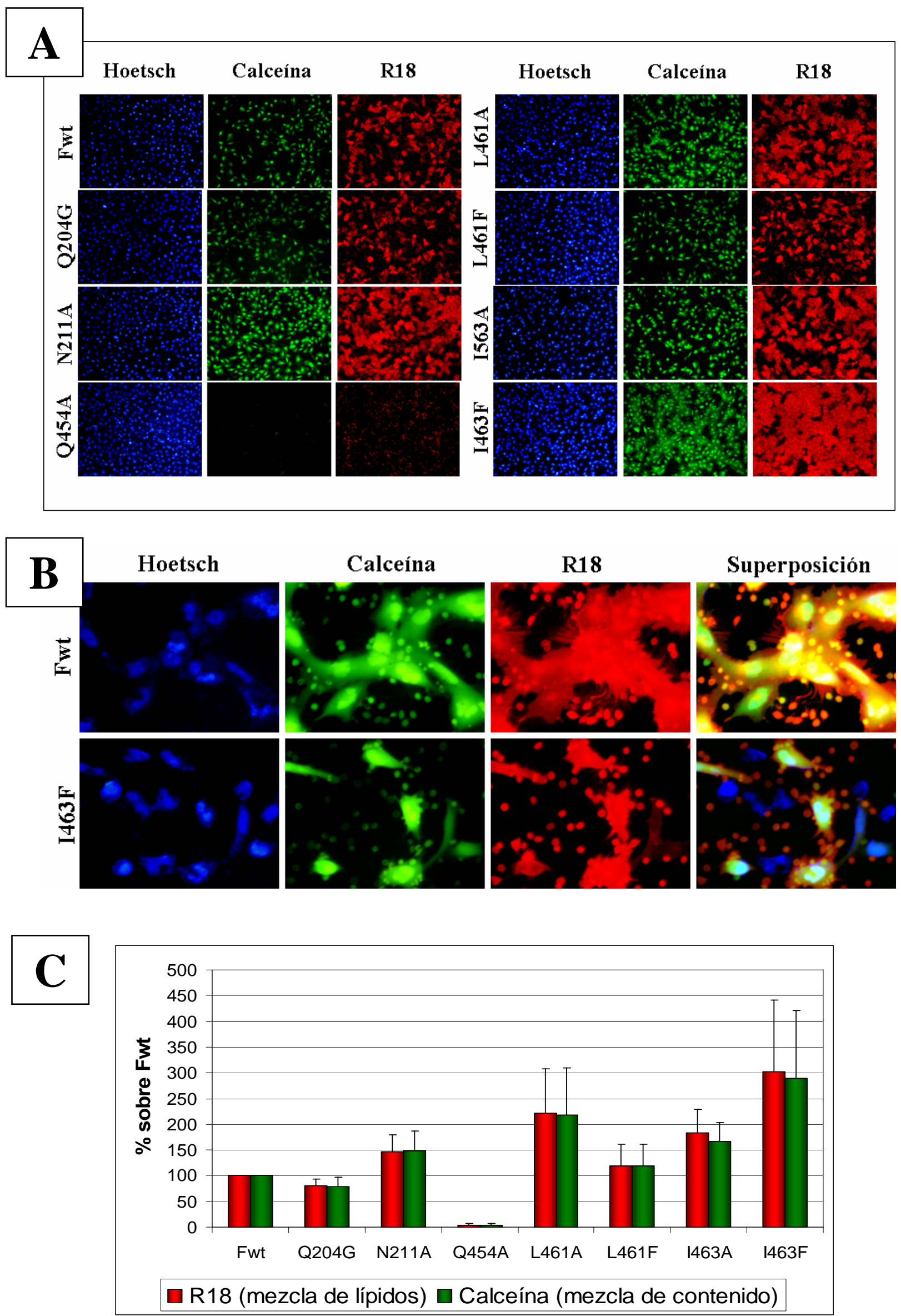
(Página anterior) Figura 4.28. Ensayos de transferencia de sonda para cuantificar la fusión célula-célula. Células HeLa coexpresando el tipo silvestre o los mutantes de $\mathrm{F}$ y la proteína $\mathrm{HN}$ fueron incubadas con eritrocitos marcados con las sondas R18 (roja) y calceína (verde) durante 30 min a $37^{\circ} \mathrm{C}$ tras haber sido tratadas con acetiltripsina para procesar $F_{0}$. (A).Micrografías de un experimento representativo (10X). (B).- Micrografías a 40X mostrando la transferencia de sonda con el mutante más fusogénico (I463F) y el tipo silvestre de F (Fwt). Puede observarse cómo 1463F produce sincitios aún a tiempos tan cortos como $30 \mathrm{~min}$. (C).- Cuantificación de la transferencia de lípidos y contenido. Se muestran la media y la desviación estándar de experimentos realizados por triplicado: el \% de células marcadas con calceína o R18 fue calculado en tres campos aleatorios por cada experimento y los resultados se refirieron a los valores obtenidos con Fwt.
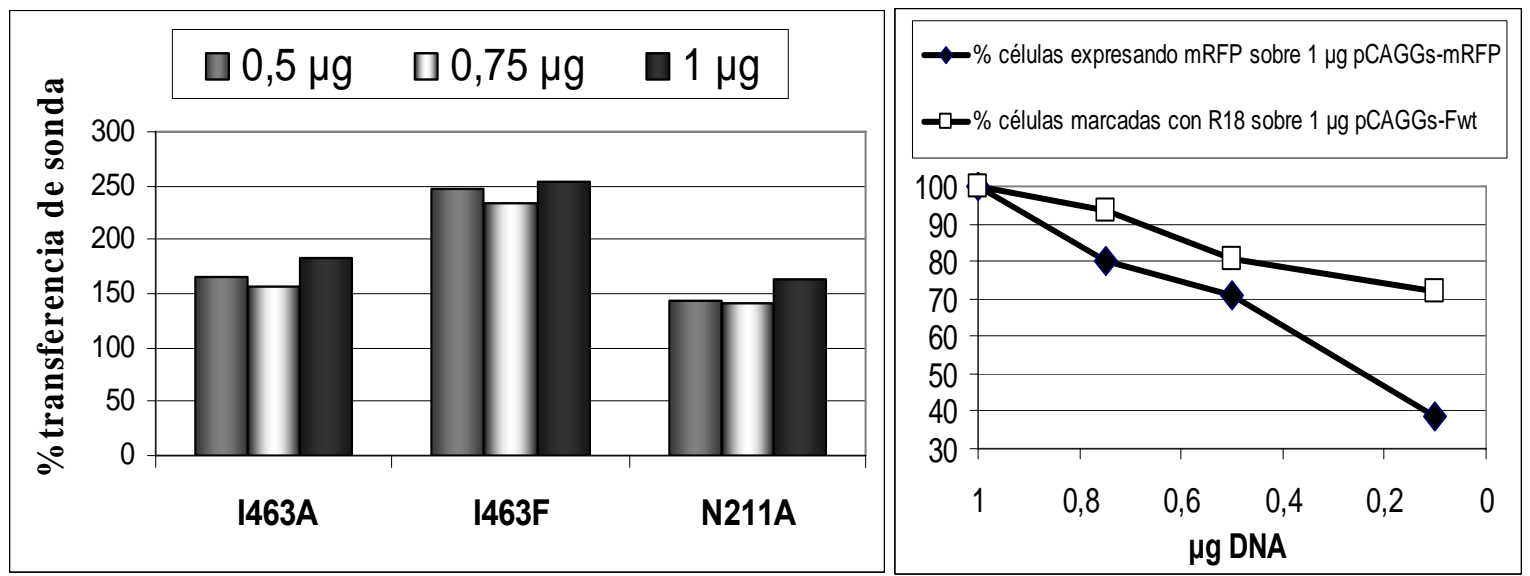

Figura 4.29. Transferencia de sonda de los mutantes N211A, I463A e I463F con distintas cantidades de DNA transfectado. (A).- Media de experimentos duplicados de transferencia de R18. Los resultados se refirieron a los obtenidos con $1 \mu \mathrm{g}$ de pCAGGsFwt $+1 \mu \mathrm{g}$ de pCAGGs-HN. (B).- Disminución en la expresión de mRFP y en la transferencia de R18 promovida por Fwt con cantidades decrecientes de DNA transfectado. Se muestran las medias de experimentos duplicados 


\subsubsection{3.- Actividad fusogénica de los mutantes N211A, I463A e I463F en ausencia de la proteína $\mathrm{HN}$.}

En los ensayos de formación de sincitios las células transfectadas con los mutantes N211A, I463A e I463F habían formado sincitios incluso sin ser cotransfectadas con la proteína HN homotípica. Para analizar este fenómeno se realizaron nuevos experimentos de transferencia de sonda, cotransfectando en este caso Fwt o los mutantes hiperfusogénicos junto con la proteína HA del virus de la gripe como proteína de unión al receptor. HA tiene en sí misma capacidad fusogénica, pero ésta sólo se activa a $\mathrm{pH}$ ácido por lo que en nuestras condiciones experimentales no generó fondo alguno (no mostrado). La Figura 4.30 muestra los resultados de estos estudios: los tres mutantes N211A, I463A e I463F indujeron la transferencia de las sondas R18 y calceína al coexpresarse con HA. Ambas sondas se transfirieron con igual eficiencia para cada mutante.

Al observarse en estudios preliminares un retardo en la fusión promovida por los mutantes con respecto a la que tenía lugar en presencia de HN (datos no mostrados), se analizó la transferencia de sonda en ausencia de $\mathrm{HN}$ a distintos tiempos (Figura 4.30B). Cuando los eritrocitos se incubaron con las células efectoras durante $210 \mathrm{~min}$, el periodo más largo de los que se probaron, los tres mutantes indujeron la fusión célulacélula en ausencia de HN. Estos resultados están en consonancia con los obtenidos en el ensayo de formación de sincitios a las tres horas (Figura 4.27, paneles -HN). Sin embargo, no pudo observarse transferencia de sonda después de incubar 30min, a diferencia de los datos de coexpresión con HN. El mutante I463A resultó ser el más dependiente de la proteína $\mathrm{HN}$ : a los 210min el valor de transferencia de sonda fue el $50 \%$ del de $\mathrm{Fwt}+\mathrm{HN}$ a los $30 \mathrm{~min}$, mientras que al coexpresarse con $\mathrm{HN}$ este valor alcanzó el 200\%. A los mayores periodos de tiempo estudiados el mutante N211A indujo la fusión célula-célula a niveles sólo ligeramente inferiores que los obtenidos al coexpresarse con $\mathrm{HN}$. El mutante I463F, el más fusogénico en presencia de HN, tuvo en ausencia de ésta un comportamiento similar al de N211A. 


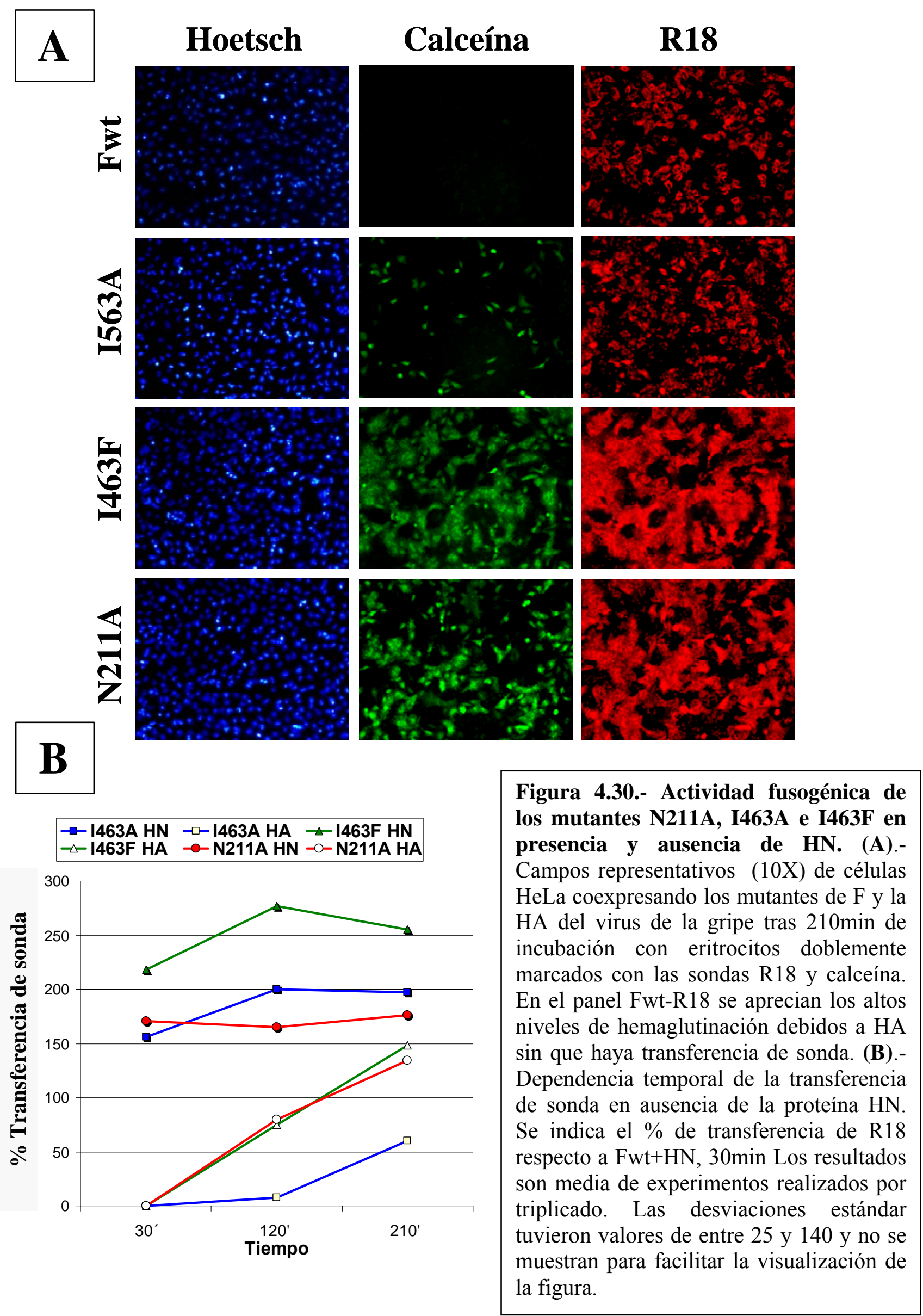




\subsubsection{4.- Efecto de la temperatura en la actividad fusogénica de los mutantes.}

Estudios anteriormente publicados han propuesto que ciertas mutaciones en la proteína $\mathrm{F}$ implican un descenso de la barrera energética que debe superarse para que pueda llevarse a cabo la fusión (Paterson et al., 2000). Por ello, quisimos analizar si el fenotipo hiperfusogénico que mostraban varios de los mutantes estudiados se debía a una alteración de sus requisitos energéticos. Se realizaron nuevos ensayos de transferencia de sonda en función de la temperatura como se han descrito anteriormente, incubando células HeLa expresando $\mathrm{HN}$ y las proteínas $\mathrm{F}$ con eritrocitos doblemente marcados con calceína y R18. En este caso la incubación se llevó a cabo durante 30 min a distintas temperaturas: $25^{\circ} \mathrm{C}, 29^{\circ} \mathrm{C}, 31,5^{\circ} \mathrm{C}$ y $37^{\circ} \mathrm{C}$. La Figura 4.31 muestra los resultados de transferencia de contenidos (calceína), si bien los datos de transferencia de lípidos (R18) fueron similares (no mostrado). Los resultados fueron referidos en todos los casos a los de $\mathrm{Fwt}+\mathrm{HN}$ a $37^{\circ} \mathrm{C}$.

Todas las proteínas, excepto Q454A, determinaron la transferencia de sonda por encima de $25^{\circ} \mathrm{C}$. A esa temperatura y por debajo de ella no pudo apreciarse transferencia en ningún mutante ni en el tipo silvestre. La actividad fusogénica de Fwt se redujo a un $50 \%$ a $31,5^{\circ} \mathrm{C}$ y a un $30 \%$ a $29^{\circ} \mathrm{C}$, resultados similares a los obtenidos con Q204G. El resto de los mutantes (N211A, L461A, L461F, I463A e I463F) mantuvieron su fenotipo más fusogénico que el de Fwt a las tres temperaturas permisivas analizadas. A $29^{\circ} \mathrm{C}$ los mutantes N211A y L461A indujeron transferencia de sonda a niveles similares a los de Fwt a $37^{\circ} \mathrm{C}$, mientras que la construcción I463F alcanzó valores significativamente mayores. Esta mutación hiperactiva provocó la formación de sincitios incluso a $29^{\circ} \mathrm{C}$ (Figura 4.31B). El mutante Q454A no provocó transferencia de sonda en ninguna de las condiciones citadas, ni tampoco al aumentar la temperatura de incubación hasta los $45^{\circ} \mathrm{C}$ (datos no mostrados). 

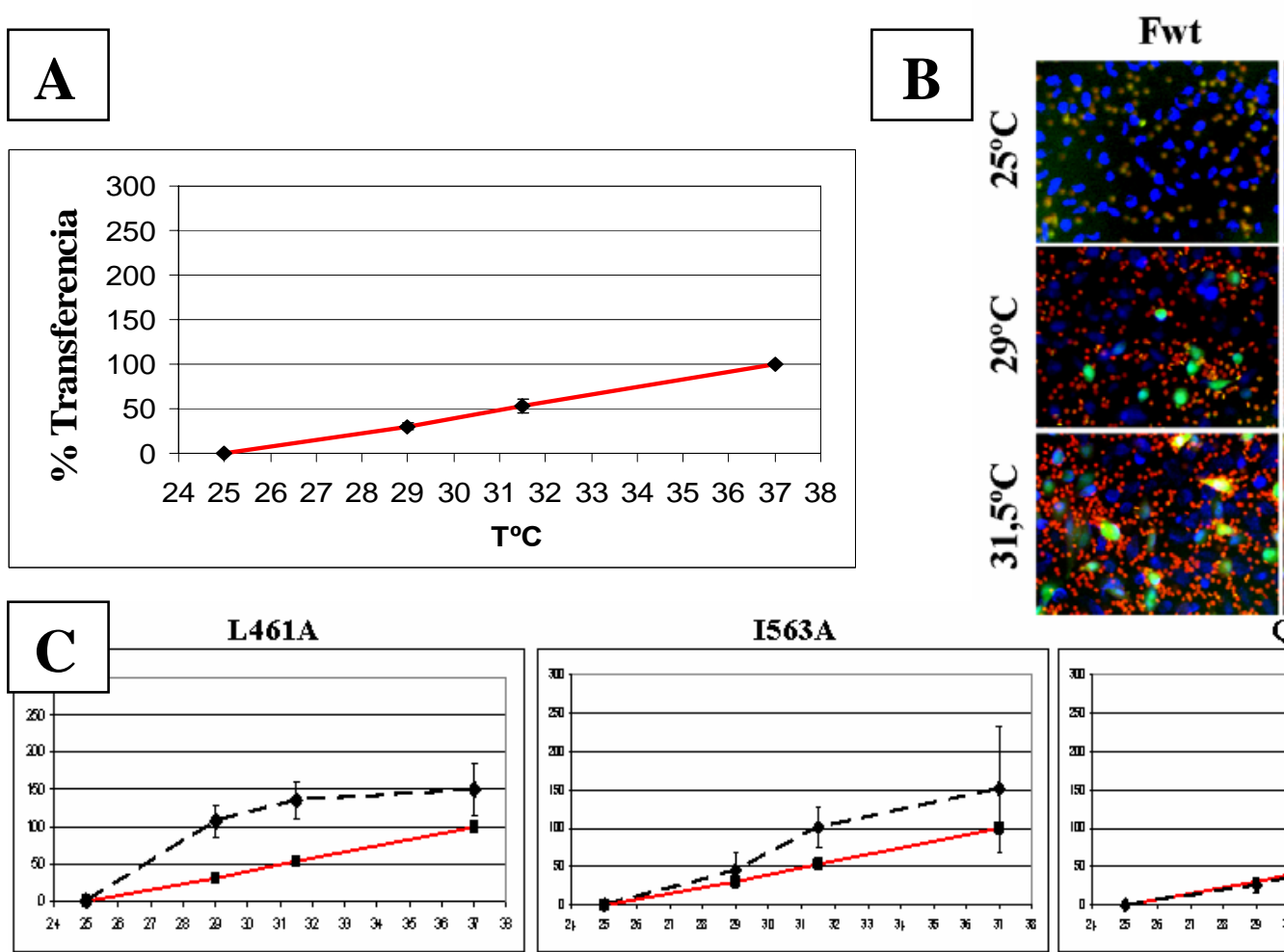

I463F
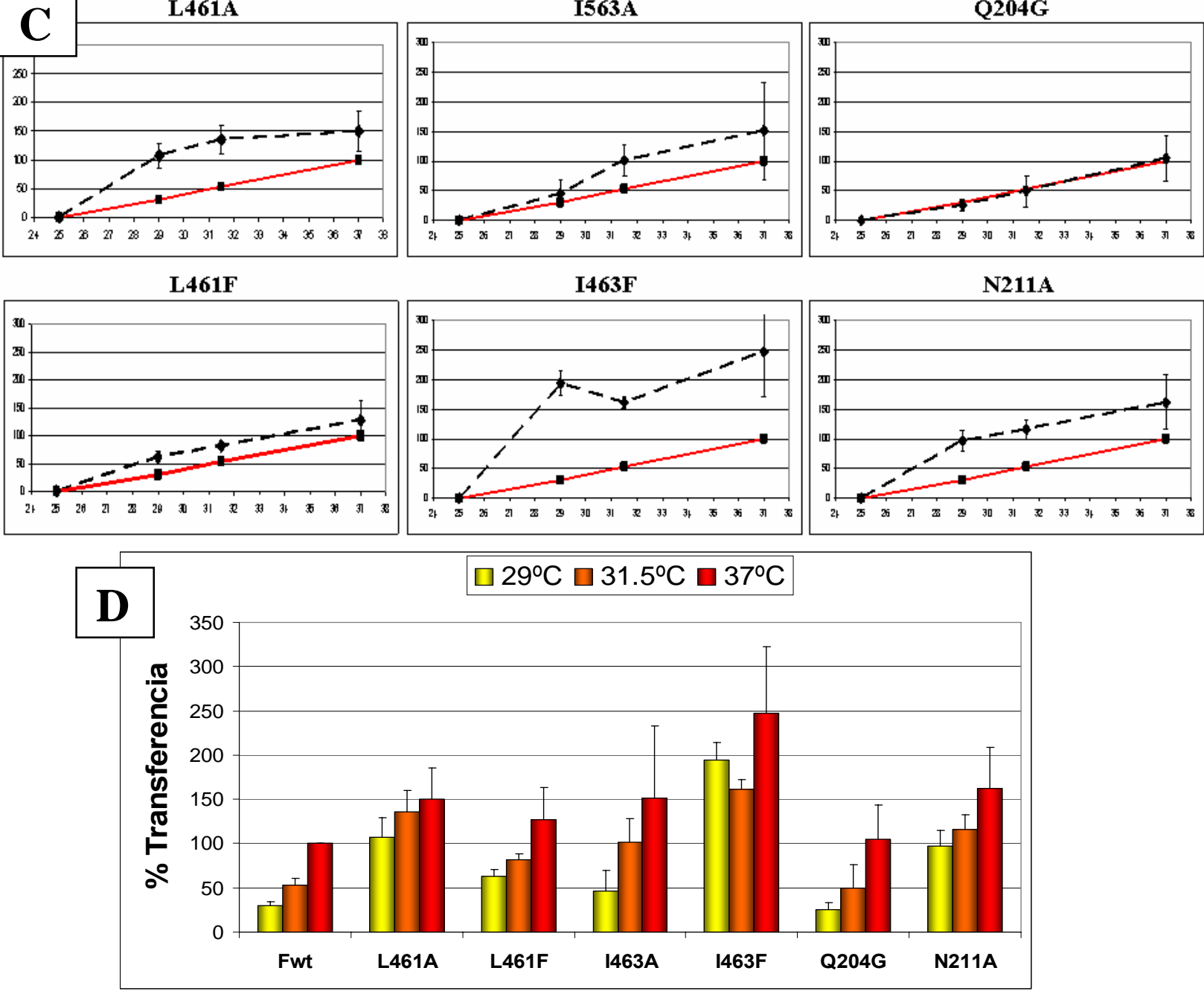

Figura 4.31.- Efecto de la temperatura sobre la fusión promovida por los mutantes de la proteína F. Células HeLa expresando $\mathrm{HN}$ y los mutantes de $\mathrm{F}$ se incubaron durante $30 \mathrm{~min}$ con eritrocitos al $2 \%$ marcados con R18 y calceína a distintas temperaturas. Tras lavar los eritrocitos no adsorbidos a las células se calculó el \% de transferencia de sonda y se refirió al de Fwt a $37^{\circ} \mathrm{C}$. Se indican la media y desviación estandar de los datos obtenidos por triplicado con calceína, siendo similares los de R18. (A).- Resultados de Fwt. (B).- Micrografías representativas comparando los fenotipos de Fwt e I463F a distintas temperaturas. (C).- Resultados de los distintos mutantes (línea negra discontinua) sobre el de Fwt (línea roia). (D).- Histograma de los resultados a $29^{\circ} \mathrm{C}, 31,5^{\circ} \mathrm{C}$ y $37^{\circ} \mathrm{C}$. 


\subsection{3.- RELEVANCIA DE LOS RESULTADOS OBTENIDOS.}

La proteína $\mathrm{F}$ en los paramixovirus tiene la función de promover la fusión de las membranas vírica y celular, permitiendo el acceso de la información genética del virus al citoplasma y el inicio del ciclo infectivo. Este paso es necesario para todos los virus con envoltura, si bien evolutivamente se han desarrollado distintas estrategias para llevarlo a cabo. En el caso de la proteína $\mathrm{F}$ de paramixovirus, está establecido que la fusión tiene lugar a $\mathrm{pH}$ neutro y en la misma membrana plasmática, y sigue un mecanismo común para las proteínas de fusión víricas denominadas de clase I (apartado 1.3). Este mecanismo supone una serie de cambios conformacionales tras la activación de la forma nativa, inestable, de la proteína que conducen a la formación de una estructura en forma de horquilla con un núcleo compuesto por seis $\alpha$-hélices (6HB). Los datos bioquímicos $\mathrm{y}$ estructurales publicados acerca de la proteína $\mathrm{F}$ de los paramixovirus indican que en el proceso de la fusión se suceden distintos estadios (Figura 1.9): (i) apertura del tallo formado por tres hélices HRB superenrrolladas (estadio de tallo abierto); (ii) formación de tres hélices HRA que disparan el péptido de fusión hacia la membrana diana, donde queda embebido gracias a su carácter hidrofóbico (estadio de prehorquilla), y (iii) formación de la horquilla final, con el núcleo central del $6 \mathrm{HB}$ formado por las tres hélices HRA y las tres hélices HRB asociadas de forma antiparalela (Figura 1.7). La disminución de energía libre asociada a la consecución de esta última forma, altamente estable, se postula como suficiente para permitir la yuxtaposición y mezcla de las dos membranas, puestas en contacto por la estructura de horquilla (Russell et al., 2001; West et al., 2005; Russell y Luque, 2006; Yin et al., 2005; Yin et al., 2006). A lo largo del proceso de fusión, distintas regiones del ectodominio de F sufren reestructuraciones conformacionales: numerosos estudios han revelado la importancia de ciertos residuos en HRA y HRB en el plegamiento y funcionalidad de la proteína en paramixovirus (Sergel et al., 1994; Sergel et al., 2001; McGinnes et al., 2001; Russell et al., 2003; Luque y Russell; 2007). En el presente trabajo nos planteamos explorar la importancia que otros residuos del ectodominio de $\mathrm{F}$ pudieran tener en la estabilización estructural de la proteína, su replegamiento y su funcionalidad. Para ello, realizamos sustituciones dirigidas de determinados aminoácidos y analizamos el comportamiento de los mutantes tras ser expresados en sistemas celulares. 
En la forma nativa, inestable de la proteína $\mathrm{F}$, la región HRA se encuentra dividida en once segmentos: cuatro $\alpha$-hélices (h1-h4), dos hebras $\beta$ (b1, b2) y los giros que las unen (Figura 4.32; Yin et al., 2006). Hemos analizado los residuos Q204 y N211, situados en posiciones $d$ de la heptada repetida en el extremo carboxilo terminal de HRA, correspondiente a la hélice h4. Ambos residuos fueron sustituidos por aminoácidos alifáticos apolares (G y A, respectivamente): el mutante Q204G mostró la misma reactividad con los anticuerpos empleados y la misma necesidad de la HN homotípica para inducir fusión que Fwt, y produjo niveles de transferencia de sonda iguales o ligeramente inferiores a los del tipo silvestre, por lo que se puede deducir que tal sustitución no afectó significativamente a la estructura y función de la proteína. Sin embargo, N211A mostró una reactividad distinta con los anticuerpos, que puede indicar una disposición espacial distinta en el dominio DIII, y dio lugar a un fenotipo hiperfusogénico a todas las temperaturas ensayadas. Es más: N211A demostró actividad fusogénica independiente de $\mathrm{HN}$ al expresarse sola (en ensayos de formación de sincitios) o coexpresarse con la proteína HA (en ensayos de transferencia de sonda). La coexpresión con la proteína $\mathrm{HN}$ aceleró la fusión en los ensayos de transferencia de sonda, pero sin ella N211A mostró los mismos niveles de fusión que Fwt $+\mathrm{HN}$, si bien a tiempos mayores. En conjunto, estos datos sugieren un gran efecto en la funcionalidad de la proteína F producido por la sustitución de N211, que rebajaría sustancialmente la barrera energética precisa para el cambio conformacional asociado al mecanismo de fusión incluso en ausencia de HN. Hay distintas posibilidades para explicar este efecto, sin que sean excluyentes entre ellas: (i) N211 es un residuo clave en la estabilización de la conformación prefusogénica de la proteína F, (ii) N211 es un un residuo clave en el reensamblaje de HRA que conduce a la formación de la prehorquilla (Figura 1.9), y (iii) N211 es un residuo clave en la interacción con la proteína HN. La comparación de las estructuras cristalográficas pre y posfusogénicas de distintos paramixovirus sugiere que los residuos polares de h4 (Figura 4.32) pueden estar implicados en la regulación del empaquetamiento del resorte molecular que es HRA (Yin et al., 2006). Nuestros datos apoyan esta teoría y parecen indicar que la sustitución de N211 por una alanina, pequeña y apolar, perturba interacciones importantes establecidas por $\mathrm{h} 4$, desestabilizando el dominio DIII y favoreciendo el repliegue de la proteína a una forma más estable, incluso sin la participación de la proteína HN. Según los datos cristalográficos (Chen et al., 2001; Yin et al., 2006), h4 se encuentra muy próxima a la hélice formada por HRC, tanto en las conformaciones pre como posfusogénicas (Figura 

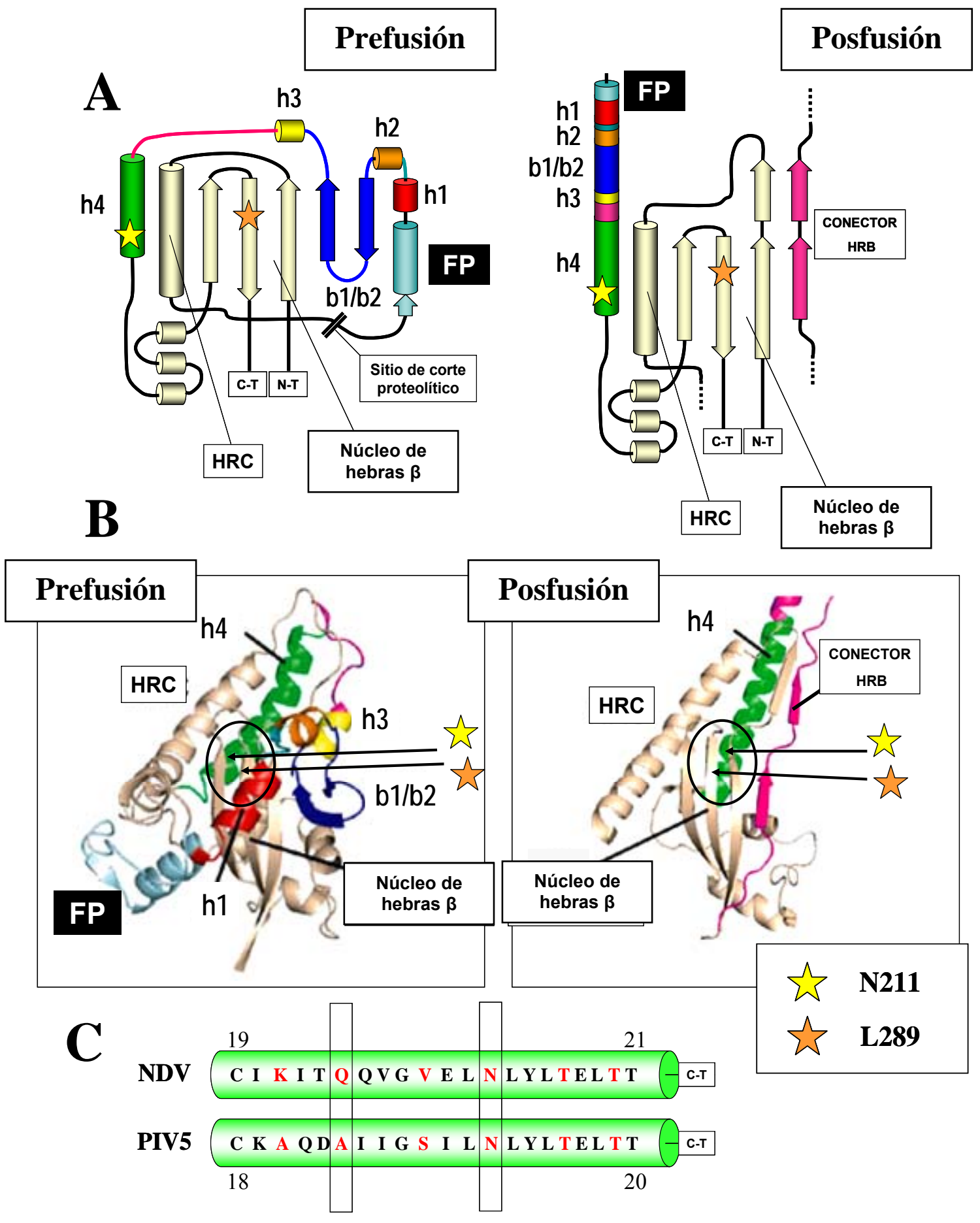

Figura 4.32.- La mutación N211A, el dominio DIII y HRA. (A).- Diagrama del dominio DIII, mostrando la reorganización de los distintos segmentos de HRA durante el proceso de activación de la proteína $\mathrm{F}$. Se indica también la posición del péptido de fusión (FP), el sitio de corte proteolítico, la hélice HRC y el núcleo de hebras $\beta$. (B).Modelo tridimensional de $\mathrm{h} 4 \mathrm{y}$ su entorno en las formas pre y posfusogénicas de la proteína $\mathrm{F}$ de paramixovirus (Yin et al., 2006). H4, HRC y el núcleo de láminas $\beta$ permanecen espacialmente próximas y alteran relativamente poco su estructura en las dos conformaciones, en comparación con la drástica reorganización del resto de los segmentos de HRA. El patrón de colores es el mismo que en (A). En (A) y en (B) se indican con estrellas las localizaciones de los residuos desestabilizantes N211 y L289 (Li et al., 2005). (C).- Comparación de h4 en el NDV y PIV5. Se resaltan los residuos $\mathrm{Q}$ y $\mathrm{N}$ mutados en el presente trabajo. En rojo aparecen los aminoácidos en posiciones a y d de la HR. 
4.32); N211A podría estar alterando las interacciones entre ambas hélices, desestabilizando la zona. Diversos estudios de HRC en distintos paramixovirus han demostrado su importancia para el funcionamiento de la proteína F. La mutación de determinados residuos puede conducir bien a hipefusogenicidad, bien a defectos en el procesamiento o a alterar la actividad de la proteína (Plemper y Compans, 2003, en MeV; Gardner y Dutch, 2007, en PIV5 y HeV). La mutación de distintos residuos en la región HRC del NDV da lugar a proteínas no funcionales (datos no mostrados), lo que permite suponer que también en este virus juega una importancia crítica. Los estudios de mutagénesis de HRA se han centrado hasta la fecha en otras regiones distintas de h4, situadas más hacia el extremo N-terminal (Sergel et al., 1994; Sergel et al., 2001; West et al., 2005; Luque y Russell, 2007), y los fenotipos resultantes de las mutaciones realizadas han mostrado en general ser defectivos en fusión, si bien también hay casos de hiperfusogenicidad. Puesto que la región N-terminal de HRA sufre los cambios conformacionales más drásticos, los mutantes no fusogénicos estarían impidiendo dicha reorganización y el consiguiente lanzamiento del péptido de fusión, mientras que los mutantes hiperfusogénicos desestabilizarían, como N211A, la forma inestable del DIII. Sin embargo, ninguna de las mutaciones en HRA o HRC descritas hasta la fecha supera el requerimiento de la proteína $\mathrm{HN}$ como hace N211A. No obstante, la mutación en la proteína $\mathrm{F}$ del NDV de un residuo del núcleo de hebras $\beta$ contiguo a HRC y HRA (L289A, descrita por Segel et al., 2000, ver Figura 4.32) si que confiere independencia de la proteína $\mathrm{HN}$, al menos en ciertos tipos celulares. Originalmente descrito en células COS-7, posteriormente se publicó que el mutante L289A, si bien mantenía el fenotipo hiperfusogénico, no era independiente de HN en células BHK (Li et al., 2005). De especial relevancia es el hecho de que en este último trabajo se menciona que L289A, al igual que N211A, puede ser reconocido diferencialmente por distintos anticuerpos, lo que sugiere que ambos están induciendo un cambio conformacional en el ectodominio de la proteína F. El núcleo de hebras $\beta$ forma, junto a las hélices HRC y h4, un conjunto cuya disposición permanece prácticamente intacta a través de los sucesivos estadios conformacionales que atraviesa la proteína F. Por todo ello, en definitiva, proponemos que $\mathrm{HRC}$, el núcleo de láminas $\beta \mathrm{y}$ h4 proporcionan la plataforma precisa para el reensamblaje de HRA y la reordenación de DIII tras la activación de la proteína F. La desestabilización de tal plataforma provocada por mutantes como N211A (del presente trabajo) y L289A (Segel et al., 2000) dispararía el mecanismo que, de forma natural, viene mediado por la actividad promotora de fusión de la proteína HN. 
En el cristal de la forma posfusogénica de la proteína F del NDV (Chen et al., 2001), el segmento Q445-Q454 emerge del dominio DII para entrar en el surco formado por la triple hélice de las HRA, justo por encima del núcleo de DIII representado en la Figura 4.32. Este segmento pertenece al conector HRB (residuos 422-425 en PIV5, que se corresponden con 435-459 en el NDV), una region posiblemente flexible (Baker et al., 1999) que se postula crucial en la apertura del tallo formado por HRB y su posterior reubicación junto a HRA formando el 6HB posfusogénico (Yin et al., 2006, Figura 4.33). El residuo Q454 del NDV, que se corresponde con Q440 de

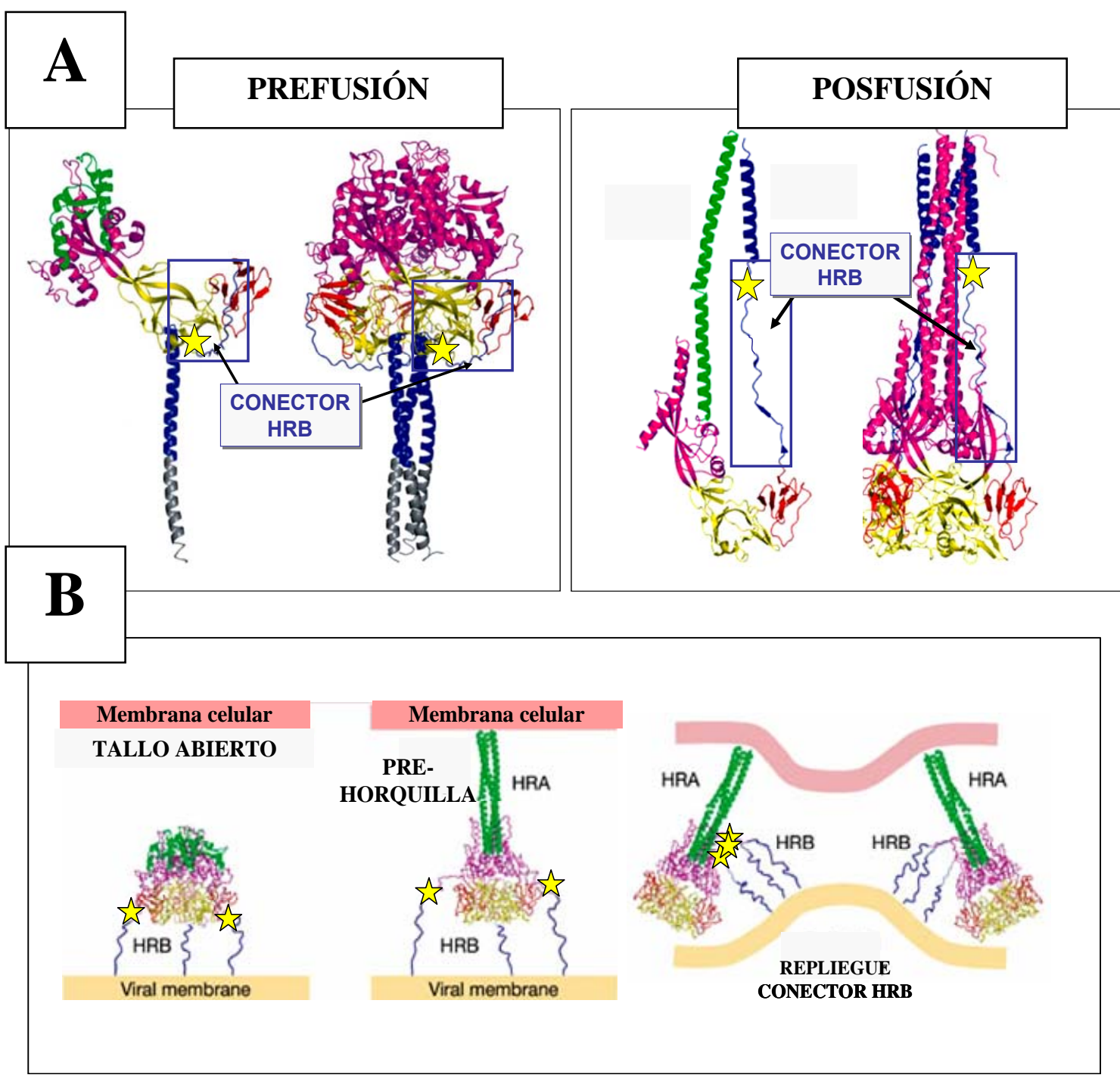

Figura 4.33.- La mutación Q454A y el conector HRB. (A).- Localización del conector $\mathrm{HRB}$ en las formas pre y posfusogénicas de la proteína $\mathrm{F}$ (monómero y trímero). La posición aproximada del residuo Q454 se muestra con una estrella. (B).Papel del conector HRB en el mecanismo propuesto para la fusión: por su flexibilidad y su posición como nexo entre HRB y la cabeza de la proteína se postula que debe reposicionarse para abrir el tallo y conducir el repliegue de HRB hasta la formación de la horquilla (adaptado de Yin et al., 2006) 
PIV5 fue mutado por alanina en el presente trabajo. La proteína mutante Q454A se expresó en la superfice celular y fue reconocida por anticuerpos de manera similar a la del tipo silvestre; sin embargo, no fue capaz de promover ni fusión ni hemifusión de membranas en ninguno de los supuestos ensayados, ni siquiera cuando la temperatura se elevó hasta $45^{\circ} \mathrm{C}$ (datos no mostrados). Es probable que la sustitución de una glutamina por una alanina, apolar y más pequeña, produzca importantes alteraciones bien en las interacciones que tienen lugar en la forma nativa de la proteína, bien durante el proceso de repliegue en el que el conector HRB juega un papel tan importante. En el PIV5, el cambio de S443 (a tres residuos de distancia de Q440, que se corresponde con el Q454 del NDV) por prolina dio lugar a un fenotipo hiperfusogénico, funcional incluso en ausencia de HN (Paterson et al., 2000). En la estructura cristalográfica de PIV5, S443 forma puentes de hidrógeno con el cercano D445 (Yin et al., 2006), y se ha descrito como un importante estabilizador de la forma prefusogénica de la proteína. La ausencia de fusión promovida por el mutante Q454A puede implicar una modificación del conector HRB por la cual éste pierda su flexibilidad y se impida la apertura inicial del tallo o bien la transición del estado de prehorquilla al de 6HB (Figura 4.33B). Otra posibilidad es que el conector actúe habitualmente como un estabilizante de la forma inestable: si ello fuera así la mutación Q454A podría estar afectando ese papel y provocando un cambio conformacional inespecífico de esa zona de la proteína hacia la forma estable en ausencia de la membrana diana, inactivándola de esa manera para llevar a cabo posteriormente la fusión. Una tercera hipótesis es que la mutación actúe a la inversa, i.e. estabilizando la forma prefusogénica y aumentando la energía de activación precisa para desencadenar la fusión, si bien esta opción no parece probable puesto que el aumento de la temperatura a la que se realizaron los ensayos no revirtió el fenotipo no fusogénico. Un estudio más detallado de este mutante, por ejemplo con el uso de péptidos y anticuerpos específicos para los distintos estadios del mecanismo de fusión, sería interesante para detectar en qué momento de los cambios conformacionales propuestos afecta al funcionamiento de la proteína $\mathrm{y}$, en última instancia, perfilar el papel de conector HRB.

Por último, nuestros datos sobre las mutaciones en los aminoácidos L461 e I463 confirman su papel clave en la funcionalidad de la proteína $\mathrm{F}$ de los paramixovirus, propuesto con anterioridad (Russell et al., 2003). Estos residuos se localizan en el extremo N-terminal de HRB, en la intersección entre cabeza y cuello (Figura 4.34), y 


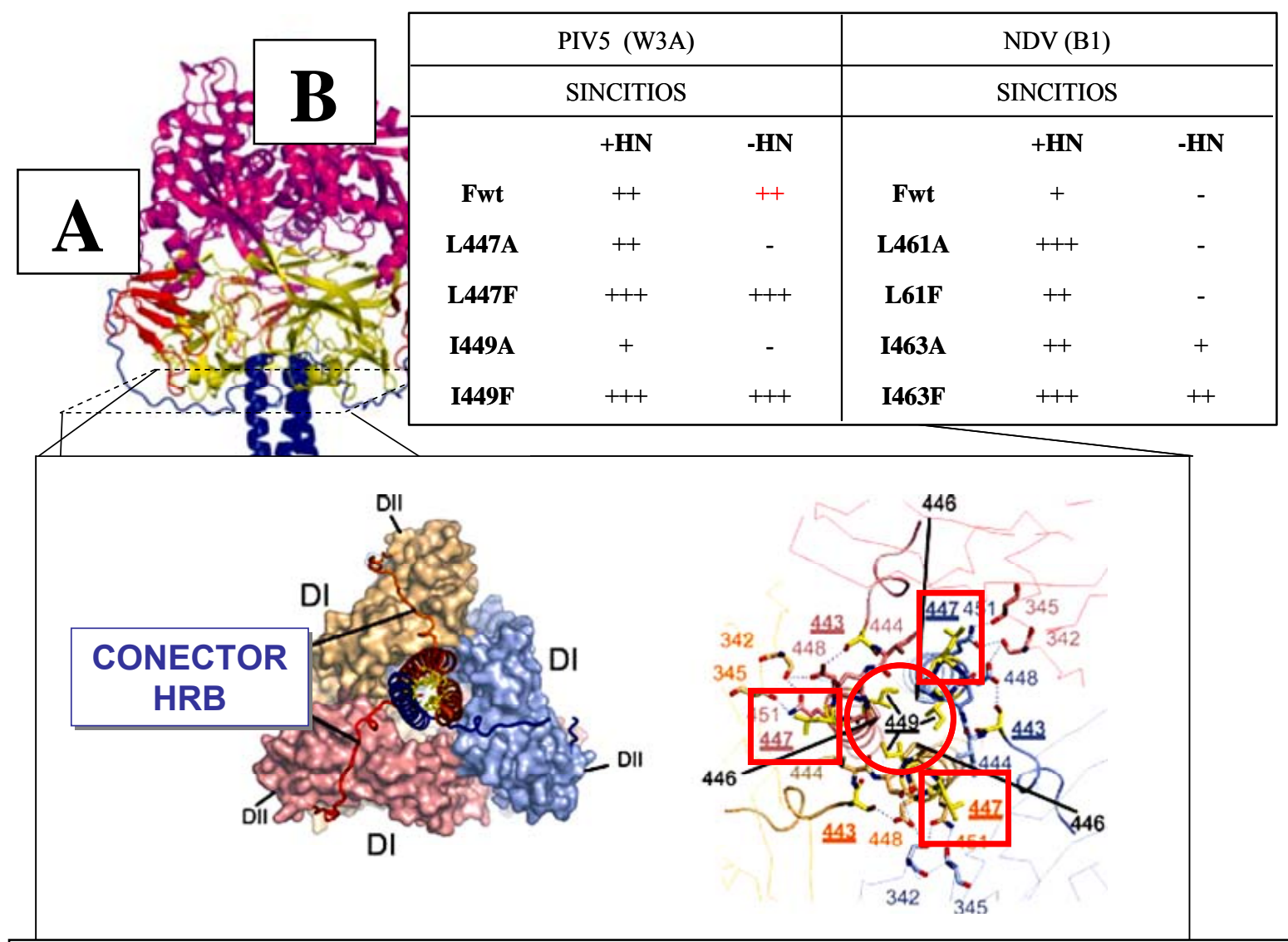

Figura 4.34.- Los aminoácidos L461 e I463. (A).- Modelo molecular de la base de la cabeza y el extremo del tallo con las tres hélices HRB (PIV5, Yin et al., 2006). Se muestra la posición central de los residuos L447 e I449, que se corresponden con L461 e I463 en el NDV. (B).- Vista conjunta de los efectos de las mutaciones en L447/I449 (PIV5) y L461/I463 (NDV) sobre la formación de sincitios. Se aprecia la importancia de los residuos en ambos vírus, pero la comparación es dificilmente interpretable por la diferencia en los fenotipos de los tipos silvestres (resaltada en rojo)

contribuyen a las numerosas interacciones entre subunidades que tienen lugar en esa región estabilizando la conformación inestable de la forma prefusogénica. En el PIV5, la sustitución de los correspondientes residuos L447 e I449 por aminoácidos aromáticos desestabiliza la proteína, no así cuando la sustitución es por restos alifáticos (Russell et al., 2003). Sin embargo, en nuestro trabajo con la proteína F del NDV ambos tipos de sustituciones produjeron formas hiperfusogénicas. Los mutantes promovieron la fusión célula-célula a temperaturas más bajas que Fwt, lo que indica menores requerimientos energéticos para la fusión que en éste. Nuestros datos muestran una mayor actividad fusogénica de los mutantes cuando L461 se sustituye por alanina, al contrario que lo descrito por Russell et al. (2003). Sin embargo, la estricta comparación entre ambos trabajos resulta complicada, puesto que la cepa de PIV5 utilizada por Russell et al. (W3A) tiene una proteína $\mathrm{F}$ mutante con una barrera energética menor, que ya de por sí es capaz de promover fusión en ausencia de la proteína HN. Esto supone que la 
interpretación de la acumulación de mutaciones en la proteína F de PIV5(W3A) y su comparación con otras proteínas $\mathrm{F}$ de paramixovirus sea díficil. En cualquier caso, como se muestra en la Figura 4.34B, tanto en el estudio de Russell y colaboradores como en el nuestro la sustitución por un resto alifático de L447/L461 resulta en un fenotipo más alejado del tipo silvestre que la sustitución por uno aromático. Según nuestros datos, sólo las dos mutaciones en I463 confieren independencia de HN para la fusión, aun cuando los niveles de fusión de L461A sean mayores que los de I463A. Esto parece indicar que la hiperfusogenicidad no está necesariamente vinculada a la presencia de la proteína $\mathrm{HN}$, y que puede existir un mecanismo distinto en la activación de $\mathrm{F}$ que el de rebajar la barrera energética. Existe consenso respecto a que el tallo de la proteína $\mathrm{F}$ juega un papel fundamental en la interacción con $\mathrm{HN}$ (apartado 1.3.3): nuestros datos permiten suponer que el extremo N-terminal de HRB participa en esa interacción, que podría localizarse en el residuo I463 dado el drástico efecto que ejerce su sustitución para el papel promotor de fusión de la proteína HN. Esta hipótesis se ve fortalecida por el distinto reconocimiento por anticuerpos que presentan los mutantes independientes de $\mathrm{HN}$ con respecto a Fwt, ya comentada antes al referirnos al mutante N211A. La distinta reactividad a los anticuerpos compartida por estos mutantes podría significar un estadio intermedio, tras la actuación de HN y previo el desencadenamiento del resto de los cambios conformacionales en la proteína F.

En resumen, en el presente trabajo se muesta que varios residuos situados en distintos segmentos de la proteína $\mathrm{F}$ pueden ser críticos en el mecanismo de fusión promovido por ésta. Futuros estudios podrían permitir discriminar más claramente cada uno de sus papeles, como los que juegan las sustituciones N211 o I463 en la interacción con $\mathrm{HN}$, o el momento en que actúa la inhibición por Q454A. También resultaría interesante el análisis de la combinación de distintas mutaciones en la misma proteína, para elucidar, por ejemplo, si una de las mutaciones hiperfusogénicas puede revertir la inhibitoria Q454. Por último, y combinando las dos partes de la presente tesis doctoral, el rescate de virus recombinantes portando las mutaciones descritas podría permitir, de ser viable, no sólo el estudio de los mutantes en el contexto real de una infección, sino también ahondar en las capacidades del NDV como vector antitumoral, ya que su capacidad oncolítica se ha relacionado directamente con la capacidad de la proteína $\mathrm{F}$ para producir sincitios (Bateman et al., 2002; Vigil et al., 2007; apartado 1.4.2.3). 

5.- CONCLUSIONES 
1. Se han construido y rescatado virus de la enfermedad de Newcastle recombinantes, de las cepas Hitchner-B1 y Hitchner-B1/F3aa, con las fase de lectura abiertas de la L-endoglina humana $y$ de una quimera endoglina/proteína F del NDV.

2. Esas proteínas foráneas se expresan en células en cultivo y se incorporan a las envolturas de los viriones que geman de la célula infectada.

3. Los niveles de endoglina expresados son superiores a los obtenidos hasta la fecha por otros métodos, lo que permite el uso de estos NDV recombinantes como vectores de expresión para la obtención de la proteína.

4. Los NDV recombinantes con el gen de la endoglina pueden infectar cultivos primarios de células mesangiales humanas y murinas, produciéndose altos niveles de expresión de endoglina. Estos recombinantes suponen una novedad metodológica, ya que e cultivos primarios de este tipo de células no pueden ser transfectados por otros procedimientos.

5. La sobreexpresión de endoglina causada por la infección modifica la acumulación de matriz extracelular, situación que se produce en ciertas patologías fibróticas. Nuestros NDV recombinantes podrían entonces ser útiles para el desarrollo de modelos celulares que reproduzcan sus efectos.

6. La sustitución de la glutamina 204 por una glicina en la región HRA de la proteína F del NDV produce el mismo fenotipo que el tipo silvestre. No se ven alteradas ni la expresión ni la actividad fusogénica de la proteína.

7. La sustitución de la asparragina 211 por una alanina en la región HRA genera una proteína F que induce mayores niveles de fusión al coexpresarse con la proteína HN homotípica, y que puede producir fusión incluso en ausencia de ésta. La mutación rebaja el umbral de activación de la proteína F. La región h4 de la HRA del NDV, a la que pertenece el residuo asparragina 211, se revela entonces como clave en la activación de la proteína F. 
8. La sustitución de la glutamina 454 por alanina en el conector HRB de la proteína $\mathrm{F}$ se expresa igual que el tipo silvestre pero es una proteína no funcional, indicando que este conector es importante en el mecanismo de fusión del NDV.

9. En el tallo HRB de la proteína F del NDV, la sustitución de la leucina 461 por alanina o fenilalanina genera proteínas que se expresan al mismo nivel que el tipo silvestre pero inducen mayores niveles de fusión que éste. Ambas rebajan el umbral de activación de la proteína..

10. En el tallo HRB de la proteína F, la sustitución de la isoleucina 463 por alanina o fenilalanina genera proteínas que inducen mayores niveles de fusión al coexpresarse con la proteína HN homotípica, y que pueden producir fusión incluso en ausencia de ésta. Ambas mutaciones rebajan su umbral de activación. En la región HRB del NDV, la leucina 461 y sobre todo la isoleucina 463 son cruciales para la funcionalidad de la proteína F. 


- Abell, B. A. y Brown, D. T. (1993). Sindbis virus membrane fusion is mediated by reduction of glycoprotein disulfide bridges at the cell surface. J. Virol. 67:5496-5501.

- Adam, P. J., Clesham, G. J. y Weissberg, P. L. (1998). Expression of endoglin mRNA and protein in human vascular smooth muscle cells. Biochem. Biophys. Res. Commun. 247:33-37.

- Afonso, C. L. (2008). Not so fast on recombination analysis of Newcastle disease virus. J. Virol. 82:9303.

- Al Garib, S. O., Gielkens, A. L., Gruys, E., Peeters, B. P. y Koch, G. (2003). Tissue tropism in the chicken embryo of non-virulent and virulent Newcastle diseases strains that express green fluorescence protein. Avian Pathol. 32:591-596.

- Alexander, D. J.(1997). Newcastle desease and other avian paramyxoviridae infections, pp. 541-570. En Diseases of Poultry, 10 a ed., B. W. Calnek, H. J. Barnes, C. W. Beard, L. R. McDougald, y Y. M. Saif (eds.) Iowa State University Press, Iowa.

- Aloia, R. C., Tian, H. y Jensen, F. C. (1993). Lipid composition and fluidity of the human immunodeficiency virus envelope and host cell plasma membranes. Proc. Natl. Acad. Sci. U. S. A 90:5181-5185.

- Altomonte, M., Montagner, R., Fonsatti, E., Colizzi, F., Cattarossi, I., Brasoveanu, L. I., Nicotra, M. R., Cattelan, A., Natali, P. G. y Maio, M. (1996). Expression and structural features of endoglin (CD105), a transforming growth factor beta1 and beta3 binding protein, in human melanoma. Br. J. Cancer 74:1586-1591.

- Álvarez-Muñoz, P. (2008). Papel de la endoglina en la proliferación celular y síntesis de matriz extracelular. Tesis Doctoral. Departamento de Fisiología y Farmacología. Universidad de Salamanca.

- Andrewes, C. H., Bang, F. B. y Burnet, F. M. (1955). A short description of the Myxovirus group (influenza and related viruses). Virology 1:176-184.

- Arthur, H. M., Ure, J., Smith, A. J., Renforth, G., Wilson, D. I., Torsney, E., Charlton, R., Parums, D. V., Jowett, T., Marchuk, D. A., Burn, J. y Diamond, A. G. (2000). Endoglin, an ancillary TGFbeta receptor, is required for extraembryonic angiogenesis and plays a key role in heart development. Dev. Biol. 217:42-53.

- Baker, K. A., Dutch, R. E., Lamb, R. A. y Jardetzky, T. S. (1999). Structural basis for paramyxovirus-mediated membrane fusion. Mol. Cell 3:309-319.

- Barbara, N. P., Wrana, J. L. y Letarte, M. (1999). Endoglin is an accessory protein that interacts with the signaling receptor complex of multiple members of the transforming growth factor-beta superfamily. J. Biol. Chem. 274:584-594.

- Basler, C. F. y García-Sastre, A. (2002). Viruses and the type I interferon antiviral system: induction and evasion. Int. Rev. Immunol. 21:305-337.

- Baudin, F., Bach, C., Cusack, S. y Ruigrok, R. W. (1994). Structure of influenza virus RNP. I. Influenza virus nucleoprotein melts secondary structure in panhandle RNA and exposes the bases to the solvent. EMBO J. 13:3158-3165.

- Bellon, T., Corbi, A., Lastres, P., Cales, C., Cebrian, M., Vera, S., Cheifetz, S., Massagué, J., Letarte, M. y Bernabeu, C. (1993). Identification and expression of two forms of the human transforming growth factor-beta-binding protein endoglin with distinct cytoplasmic regions. Eur. J. Immunol. 23:2340-2345. 
- Bian, H., Fournier, P., Moormann, R., Peeters, B. y Schirrmacher, V. (2005). Selective gene transfer to tumor cells by recombinant Newcastle Disease Virus via a bispecific fusion protein. Int. J. Oncol. 26:431-439.

- Birnboim, H. C. y Doly, J. (1979). A rapid alkaline extraction procedure for screening recombinant plasmid DNA. Nucleic Acids Res. 7:1513-1523.

- Bissonnette, M. L., Donald, J. E., DeGrado, W. F., Jardetzky, T. S. y Lamb, R. A. (2009). Functional analysis of the transmembrane domain in paramyxovirus $F$ protein-mediated membrane fusion. J. Mol. Biol. 386:14-36.

- Blann, A. D., Wang, J. M., Wilson, P. B. y Kumar, S. (1996). Serum levels of the TGF-beta receptor are increased in atherosclerosis. Atherosclerosis 120:221-226.

- Blumberg, B., Giorgi, C., Roux, L., Raju, R., Dowling, P., Chollet, A. y Kolakofsky, D. (1985). Sequence determination of the Sendai virus HN gene and its comparison to the influenza virus glycoproteins. Cell 41:269-278.

- Blumberg, B., Giorgi, C., Rose, K. y Kolakofsky, D.(1991). The molecular biology of the Paramyxovirus genus En The Paramyxoviruses, $8^{\mathrm{a}}$ ed., D. W. Kingsbury (ed.) Plenum Press, New York.

- Bourdeau, A., Dumont, D. J. y Letarte, M. (1999). A murine model of hereditary hemorrhagic telangiectasia. J. Clin. Invest 104:1343-1351.

- Bourdeau, A., Faughnan, M. E., McDonald, M. L., Paterson, A. D., Wanless, I. R. y Letarte, M. (2001). Potential role of modifier genes influencing transforming growth factorbeta1 levels in the development of vascular defects in endoglin heterozygous mice with hereditary hemorrhagic telangiectasia. Am. J. Pathol. 158:2011-2020.

- Bousse, T. L., Taylor, G., Krishnamurthy, S., Portner, A., Samal, S. K. y Takimoto, T. (2004). Biological significance of the second receptor binding site of Newcastle disease virus hemagglutinin-neuraminidase protein. J. Virol. 78:13351-13355.

- Bratt, M. A. y Robinson, W. S. (1967). Ribonucleic acid synthesis in cells infected with Newcastle desease virus. J. Mol. Biol. 23:1-21.

- Braverman, I. M., Keh, A. y Jacobson, B. S. (1990). Ultrastructure and three-dimensional organization of the telangiectases of hereditary hemorrhagic telangiectasia. J. Invest Dermatol. 95:422-427.

- Bridgen, A. y Elliott, R. M. (1996). Rescue of a segmented negative-strand RNA virus entirely from cloned complementary DNAs. Proc. Natl. Acad. Sci. U. S. A 93:15400-15404.

- Bukreyev, A., Huang, Z., Yang, L., Elankumaran, S., St Claire, M., Murphy, B. R., Samal, S. K. y Collins, P. L. (2005). Recombinant Newcastle disease virus expressing a foreign viral antigen is attenuated and highly immunogenic in primates. J. Virol. 79:13275-13284.

- Bukreyev, A., Skiadopoulos, M. H., Murphy, B. R. y Collins, P. L. (2006). Nonsegmented negative-strand viruses as vaccine vectors. J. Virol. 80:10293-10306.

- Burrows, F. J., Derbyshire, E. J., Tazzari, P. L., Amlot, P., Gazdar, A. F., King, S. W., Letarte, M., Vitetta, E. S. y Thorpe, P. E. (1995). Up-regulation of endoglin on vascular endothelial cells in human solid tumors: implications for diagnosis and therapy. Clin. Cancer Res. 1:1623-1634.

- Calabro, L., Fonsatti, E., Bellomo, G., Alonci, A., Colizzi, F., Sigalotti, L., Altomonte, M., Musolino, C. y Maio, M. (2003). Differential levels of soluble endoglin (CD105) in myeloid malignancies. J. Cell Physiol 194:171-175. 
- Calain, P., Curran, J., Kolakofsky, D. y Roux, L. (1992). Molecular cloning of natural paramyxovirus copy-back defective interfering RNAs and their expression from DNA. Virology 191:62-71.

- Calain, P. y Roux, L. (1993). The rule of six, a basic feature for efficient replication of Sendai virus defective interfering RNA. J. Virol. 67:4822-4830.

- Campbell, R. E., Tour, O., Palmer, A. E., Steinbach, P. A., Baird, G. S., Zacharias, D. A. y Tsien, R. Y. (2002). A monomeric red fluorescent protein. Proc. Natl. Acad. Sci. U. S. A 99:7877-7882.

- Cantin, C., Holguera, J., Ferreira, L., Villar, E. y Muñoz-Barroso, I. (2007). Newcastle disease virus may enter cells by caveolae-mediated endocytosis. J. Gen. Virol. 88:559-569.

- Carnero, E., Li, W., Borderia, A. V., Moltedo, B., Moran, T. y García-Sastre, A. (2009). Optimization of human immunodeficiency virus gag expression by Newcastle disease virus vectors for the induction of potent immune responses. J. Virol. 83:584-597.

- Cassel, W. A. y Garrett, R. E. (1965). Newcastle disease virus as an antineoplastic agent. Cancer 18:863-868.

- Chang, P.(1975). Newcastle Desease En CRC Handbook Series in Zoonoses: Viral Zoonoses, CRC Press, Boca Raton.

- Cheifetz, S., Bellon, T., Cales, C., Vera, S., Bernabeu, C., Massagué, J. y Letarte, M. (1992). Endoglin is a component of the transforming growth factor-beta receptor system in human endothelial cells. J. Biol. Chem. 267:19027-19030.

- Chen, L., Gorman, J. J., McKimm-Breschkin, J., Lawrence, L. J., Tulloch, P. A., Smith, B. J., Colman, P. M. y Lawrence, M. C. (2001). The structure of the fusion glycoprotein of Newcastle disease virus suggests a novel paradigm for the molecular mechanism of membrane fusion. Structure. 9:255-266.

- Chomczynski, P. y Sacchi, N. (1987). Single-step method of RNA isolation by acid guanidinium thiocyanate-phenol-chloroform extraction. Anal. Biochem. 162:156-159.

- Choppin, P. W. y Compans, R. W.(1975). Reproduction of paramyxoviruses, pp. 95-178. En Comprehensive Virology, $4^{\mathrm{a}}$ ed., H. Fraenkel-Konrat y R. R. Wagner (eds.) Plenum Press, New York.

- Chua, K. B., Bellini, W. J., Rota, P. A., Harcourt, B. H., Tamin, A., Lam, S. K., Ksiazek, T. G., Rollin, P. E., Zaki, S. R., Shieh, W., Goldsmith, C. S., Gubler, D. J., Roehrig, J. T., Eaton, B., Gould, A. R., Olson, J., Field, H., Daniels, P., Ling, A. E., Peters, C. J., Anderson, L. J. y Mahy, B. W. (2000). Nipah virus: a recently emergent deadly paramyxovirus. Science 288:1432-1435.

- Collins, P. L., Mink, M. A. y Stec, D. S. (1991). Rescue of synthetic analogs of respiratory syncytial virus genomic RNA and effect of truncations and mutations on the expression of a foreign reporter gene. Proc. Natl. Acad. Sci. U. S. A 88:9663-9667.

- Collins, P. L., Bukreyev, A. y Murphy, B. R. (2008). What are the risks--hypothetical and observed--of recombination involving live vaccines and vaccine vectors based on nonsegmented negative-strain RNA viruses? J. Virol. 82:9805-9806.

- Conzelmann, K. K., Cox, J. H. y Thiel, H. J. (1991). An L (polymerase)-deficient rabies virus defective interfering particle RNA is replicated and transcribed by heterologous helper virus L proteins. Virology 184:655-663. 
- Conzelmann, K. K. (2004). Reverse genetics of mononegavirales. Curr. Top. Microbiol. Immunol. 283:1-41.

- Crennell, S., Takimoto, T., Portner, A. y Taylor, G. (2000). Crystal structure of the multifunctional paramyxovirus hemagglutinin-neuraminidase. Nat. Struct. Biol. 7:1068-1074.

- Cruz-Gonzalez, I., Pabon, P., Rodríguez-Barbero, A., Martin-Moreiras, J., Pericacho, M., Sanchez, P. L., Ramirez, V., Sanchez-Ledesma, M., Martin-Herrero, F., Jimenez-Candil, J., Maree, A. O., Sanchez-Rodríguez, A., Martin-Luengo, C. y López-Novoa, J. M. (2008). Identification of serum endoglin as a novel prognostic marker after acute myocardial infarction. J. Cell Mol. Med. 12:955-961.

- Csatary, L. K., Eckhardt, S., Bukosza, I., Czegledi, F., Fenyvesi, C., Gergely, P., Bodey, B. y Csatary, C. M. (1993). Attenuated veterinary virus vaccine for the treatment of cancer. Cancer Detect. Prev. 17:619-627.

- Csatary, L. K., Gosztonyi, G., Szeberenyi, J., Fabian, Z., Liszka, V., Bodey, B. y Csatary, C. M. (2004). MTH-68/H oncolytic viral treatment in human high-grade gliomas. J. Neurooncol. 67:83-93.

- de Leeuw, O. y Peeters, B. (1999). Complete nucleotide sequence of Newcastle disease virus: evidence for the existence of a new genus within the subfamily Paramyxovirinae. J. Gen. Virol. 80 ( Pt 1):131-136.

- de Leeuw, O. S., Hartog, L., Koch, G. y Peeters, B. P. (2003). Effect of fusion protein cleavage site mutations on virulence of Newcastle disease virus: non-virulent cleavage site mutants revert to virulence after one passage in chicken brain. J. Gen. Virol. 84:475-484.

- de Leeuw, O. S., Koch, G., Hartog, L., Ravenshorst, N. y Peeters, B. P. (2005). Virulence of Newcastle disease virus is determined by the cleavage site of the fusion protein and by both the stem region and globular head of the haemagglutinin-neuraminidase protein. J. Gen. Virol. 86:1759-1769.

- de Wit, E., Spronken, M. I., Vervaet, G., Rimmelzwaan, G. F., Osterhaus, A. D. y Fouchier, R. A. (2007). A reverse-genetics system for Influenza A virus using T7 RNA polymerase. J. Gen. Virol. 88:1281-1287.

- De, B. P. y Banerjee, A. K. (1993). Rescue of synthetic analogs of genome RNA of human parainfluenza virus type 3. Virology 196:344-348.

- Deng, R., Wang, Z., Glickman, R. L. y Iorio, R. M. (1994). Glycosylation within an antigenic site on the HN glycoprotein of Newcastle disease virus interferes with its role in the promotion of membrane fusion. Virology 204:17-26.

- Deng, R., Wang, Z., Mirza, A. M. y Iorio, R. M. (1995). Localization of a domain on the paramyxovirus attachment protein required for the promotion of cellular fusion by its homologous fusion protein spike. Virology 209:457-469.

- Diez-Marques, L., Ortega-Velazquez, R., Langa, C., Rodríguez-Barbero, A., López-Novoa, J. M., Lamas, S. y Bernabeu, C. (2002). Expression of endoglin in human mesangial cells: modulation of extracellular matrix synthesis. Biochim. Biophys. Acta 1587:36-44.

- Dimock, K. y Collins, P. L. (1993). Rescue of synthetic analogs of genomic RNA and replicative-intermediate RNA of human parainfluenza virus type 3. J. Virol. 67:2772-2778.

- Di Napoli, J. M., Yang, L., Suguitan, A., Jr., Elankumaran, S., Dorward, D. W., Murphy, B. R., Samal, S. K., Collins, P. L. y Bukreyev, A. (2007). Immunization of primates with a Newcastle disease virus-vectored vaccine via the respiratory tract induces a high titer of serum 
neutralizing antibodies against highly pathogenic avian influenza virus. J. Virol. 81:1156011568.

- Di Napoli, J. M., Kotelkin, A., Yang, L., Elankumaran, S., Murphy, B. R., Samal, S. K., Collins, P. L. y Bukreyev, A. (2007). Newcastle disease virus, a host range-restricted virus, as a vaccine vector for intranasal immunization against emerging pathogens. Proc. Natl. Acad. Sci. U. S. A 104:9788-9793.

- Doyle, T. M. (1927). A hiherto unrecorded disease of fowls due to a filter-passing virus. $J$. comp. Pathol. Therap. 40:144-169.

- Dunn, E. F., Pritlove, D. C., Jin, H. y Elliott, R. M. (1995). Transcription of a recombinant bunyavirus RNA template by transiently expressed bunyavirus proteins. Virology 211:133-143.

- Durbin, A. P., Hall, S. L., Siew, J. W., Whitehead, S. S., Collins, P. L. y Murphy, B. R. (1997). Recovery of infectious human parainfluenza virus type 3 from cDNA. Virology 235:323332.

- Dutch, R. E., Joshi, S. B. y Lamb, R. A. (1998). Membrane fusion promoted by increasing surface densities of the paramyxovirus $\mathrm{F}$ and $\mathrm{HN}$ proteins: comparison of fusion reactions mediated by simian virus $5 \mathrm{~F}$, human parainfluenza virus type $3 \mathrm{~F}$, and influenza virus HA. $J$. Virol. 72:7745-7753.

- Duwel, A., Eleno, N., Jerkic, M., Arevalo, M., Bolanos, J. P., Bernabeu, C. y López-Novoa, J. M. (2007). Reduced tumor growth and angiogenesis in endoglin-haploinsufficient mice. Tumour. Biol. 28:1-8.

- Egelman, E. H., Wu, S. S., Amrein, M., Portner, A. y Murti, G. (1989). The Sendai virus nucleocapsid exists in at least four different helical states. J. Virol. 63:2233-2243.

- Elankumaran, S., Rockemann, D. y Samal, S. K. (2006). Newcastle disease virus exerts oncolysis by both intrinsic and extrinsic caspase-dependent pathways of cell death. J. Virol. 80:7522-7534.

- Enami, M., Luytjes, W., Krystal, M. y Palese, P. (1990). Introduction of site-specific mutations into the genome of influenza virus. Proc. Natl. Acad. Sci. U. S. A 87:3802-3805.

- Engel-Herbert, I., Werner, O., Teifke, J. P., Mebatsion, T., Mettenleiter, T. C. y RomerOberdorfer, A. (2003) . Characterization of a recombinant Newcastle disease virus expressing the green fluorescent protein. J. Virol. Methods 108:19-28.

- Estevez, C., King, D., Seal, B. y Yu, Q. (2007). Evaluation of Newcastle disease virus chimeras expressing the Hemagglutinin-Neuraminidase protein of velogenic strains in the context of a mesogenic recombinant virus backbone. Virus Res. 129:182-190.

- Fernández-Ruiz, E., St Jacques, S., Bellon, T., Letarte, M. y Bernabéu, C. (1993). Assignment of the human endoglin gene (END) to 9q34-->qter. Cytogenet. Cell Genet. 64:204207.

- Ferreira, L., Muñoz-Barroso, I., Marcos, F., Shnyrov, V. L. y Villar, E. (2004a). Sialidase, receptor-binding and fusion-promotion activities of Newcastle disease virus haemagglutininneuraminidase glycoprotein: a mutational and kinetic study. J. Gen. Virol. 85:1981-1988.

- Ferreira, L., Villar, E. y Muñoz-Barroso, I. (2004b). Conformational changes of Newcastle disease virus envelope glycoproteins triggered by gangliosides. Eur. J. Biochem. 271:581-588.

- Fodor, E., Devenish, L., Engelhardt, O. G., Palese, P., Brownlee, G. G. y García-Sastre, A. (1999). Rescue of influenza A virus from recombinant DNA. J. Virol. 73:9679-9682. 
- Fuerst, T. R., Niles, E. G., Studier, F. W. y Moss, B. (1986). Eukaryotic transient-expression system based on recombinant vaccinia virus that synthesizes bacteriophage T7 RNA polymerase. Proc. Natl. Acad. Sci. U. S. A 83:8122-8126.

- Gainey, M. D., Manuse, M. J. y Parks, G. D. (2008). A hyperfusogenic F protein enhances the oncolytic potency of a paramyxovirus simian virus $5 \mathrm{P} / \mathrm{V}$ mutant without compromising sensitivity to type I interferon. J. Virol. 82:9369-9380.

- Gainey, M. D., Dillon, P. J., Clark, K. M., Manuse, M. J. y Parks, G. D. (2008). Paramyxovirus-induced shutoff of host and viral protein synthesis: role of the $\mathrm{P}$ and $\mathrm{V}$ proteins in limiting PKR activation. J. Virol. 82:828-839.

- Galinski, M. S. y Wechsler, S. L.(1991). The molecular biology of the Paramyxovirus genus, pp. 41-42. En The Paramyxoviruses, D. W. Kingsbury (ed.) Plenum Press, New York.

- Gao, Q., Park, M. S. y Palese, P. (2008). Expression of transgenes from Newcastle disease virus with a segmented genome. J. Virol. 82:2692-2698.

- García-Sastre, A., Cabezas, J. A. y Villar, E. (1989). Proteins of Newcastle disease virus envelope: interaction between the outer hemagglutinin-neuraminidase glycoprotein and the inner non-glycosylated matrix protein. Biochim. Biophys. Acta 999:171-175.

- García-Sastre, A. (1990). Estudios sobre las proteínas del virus de la enfermedad de Newcastle y del virus de la gripe C. Tesis Doctoral. Departamento de Bioquímica y Biología Molecular. Universidad de Salamanca.

- García-Sastre, A. (1998). Negative-strand RNA viruses: applications to biotechnology. Trends Biotechnol. 16:230-235.

- Gardner, A. E. y Dutch, R. E. (2007). A conserved region in the F(2) subunit of paramyxovirus fusion proteins is involved in fusion regulation. J. Virol. 81:8303-8314.

- Ge, J., Deng, G., Wen, Z., Tian, G., Wang, Y., Shi, J., Wang, X., Li, Y., Hu, S., Jiang, Y., Yang, C., Yu, K., Bu, Z. y Chen, H. (2007). Newcastle disease virus-based live attenuated vaccine completely protects chickens and mice from lethal challenge of homologous and heterologous H5N1 avian influenza viruses. J. Virol. 81:150-158.

- Glaser, L., Stevens, J., Zamarin, D., Wilson, I. A., García-Sastre, A., Tumpey, T. M., Basler, C. F., Taubenberger, J. K. y Palese, P. (2005). A single amino acid substitution in 1918 influenza virus hemagglutinin changes receptor binding specificity. J. Virol. 79:1153311536.

- Gougos, A. y Letarte, M. (1988). Biochemical characterization of the 44G4 antigen from the HOON pre-B leukemic cell line. J. Immunol. 141:1934-1940.

- Gougos, A. y Letarte, M. (1990). Primary structure of endoglin, an RGD-containing glycoprotein of human endothelial cells. J. Biol. Chem. 265:8361-8364.

- Gravel, K. A. y Morrison, T. G. (2003). Interacting domains of the HN and F proteins of Newcastle disease virus. J. Virol. 77:11040-11049.

- Guttmacher, A. E., Marchuk, D. A. y White, R. I., Jr. (1995). Hereditary hemorrhagic telangiectasia. N. Engl. J. Med. 333:918-924.

- Hamaguchi, M., Yoshida, T., Nishikawa, K., Naruse, H. y Nagai, Y. (1983). Transcriptive complex of Newcastle disease virus. I. Both L and P proteins are required to constitute an active complex. Virology 128:105-117. 
- Han, G. Z., Liu, X. P. y Li, S. S. (2008). Caution about Newcastle disease virus-based live attenuated vaccine. J. Virol. 82:6782.

- Hanson, R. P. y Brandly, C. A. (1955). Identification of vaccine strains of Newcastle disease virus. Science 122:156-157.

- Hanson, R. P.(1972). Newcastle disease En Diseases of poultry, M. S. Hofstad (ed.) Iowa State University Press, Iowa.

- Harty, R. N. y Palese, P. (1995). Mutations within noncoding terminal sequences of model RNAs of Sendai virus: influence on reporter gene expression. J. Virol. 69:5128-5131.

- Haruta, Y. y Seon, B. K. (1986). Distinct human leukemia-associated cell surface glycoprotein GP160 defined by monoclonal antibody SN6. Proc. Natl. Acad. Sci. U. S. A 83:7898-7902.

- Hoffmann, E. y Webster, R. G. (2000). Unidirectional RNA polymerase I-polymerase II transcription system for the generation of influenza A virus from eight plasmids. J. Gen. Virol. 81:2843-2847.

- Hoffmann, E., Neumann, G., Kawaoka, Y., Hobom, G. y Webster, R. G. (2000). A DNA transfection system for generation of influenza A virus from eight plasmids. Proc. Natl. Acad. Sci. U. S. A 97:6108-6113.

- Honda, A., Ueda, K., Nagata, K. y Ishihama, A. (1987). Identification of the RNA polymerase-binding site on genome RNA of influenza virus. J. Biochem. (Tokyo) 102:12411249.

- Honda, A., Ueda, K., Nagata, K. y Ishihama, A. (1988). RNA polymerase of influenza virus: role of NP in RNA chain elongation. J. Biochem. (Tokyo) 104:1021-1026.

- Honda, A., Mukaigawa, J., Yokoiyama, A., Kato, A., Ueda, S., Nagata, K., Krystal, M., Nayak, D. P. y Ishihama, A. (1990). Purification and molecular structure of RNA polymerase from influenza virus A/PR8. J. Biochem. (Tokyo) 107:624-628.

- Hu, S., Ma, H., Wu, Y., Liu, W., Wang, X., Liu, Y. y Liu, X. (2009). A vaccine candidate of attenuated genotype VII Newcastle disease virus generated by reverse genetics. Vaccine 27:904910.

- Huang, Z., Krishnamurthy, S., Panda, A. y Samal, S. K. (2001). High-level expression of a foreign gene from the most 3'-proximal locus of a recombinant Newcastle disease virus. J. Gen. Virol. 82:1729-1736.

- Huang, Z., Elankumaran, S., Panda, A. y Samal, S. K. (2003a). Recombinant Newcastle disease virus as a vaccine vector. Poult. Sci. 82:899-906.

- Huang, Z., Krishnamurthy, S., Panda, A. y Samal, S. K. (2003b). Newcastle disease virus V protein is associated with viral pathogenesis and functions as an alpha interferon antagonist. $J$. Virol. 77:8676-8685.

- Huang, Z., Panda, A., Elankumaran, S., Govindarajan, D., Rockemann, D. D. y Samal, S. K. (2004a). The hemagglutinin-neuraminidase protein of Newcastle disease virus determines tropism and virulence. J. Virol. 78:4176-4184.

- Huang, Z., Elankumaran, S., Yunus, A. S. y Samal, S. K. (2004b). A recombinant Newcastle disease virus (NDV) expressing VP2 protein of infectious bursal disease virus (IBDV) protects against NDV and IBDV. J. Virol. 78:10054-10063. 
- Iseni, F., Barge, A., Baudin, F., Blondel, D. y Ruigrok, R. W. (1998). Characterization of rabies virus nucleocapsids and recombinant nucleocapsid-like structures. J. Gen. Virol. 79 ( Pt 12):2909-2919.

- Jain, S., McGinnes, L. W. y Morrison, T. G. (2007). Thiol/disulfide exchange is required for membrane fusion directed by the Newcastle disease virus fusion protein. J. Virol. 81:2328-2339.

- Jain, S., McGinnes, L. W. y Morrison, T. G. (2009). Role of thiol/disulfide exchange in Newcastle disease virus entry. J. Virol. 83:241-249.

- Janke, M., Peeters, B., de Leeuw, O., Moorman, R., Arnold, A., Fournier, P. y Schirrmacher, V. (2007). Recombinant Newcastle disease virus (NDV) with inserted gene coding for GM-CSF as a new vector for cancer immunogene therapy. Gene Ther. 14:1639-1649.

- Jerkic, M., Rodríguez-Barbero, A., Prieto, M., Toporsian, M., Pericacho, M., Rivas-Elena, J. V., Obreo, J., Wang, A., Pérez-Barriocanal, F., Arevalo, M., Bernabeu, C., Letarte, M. y López-Novoa, J. M. (2006). Reduced angiogenic responses in adult Endoglin heterozygous mice. Cardiovasc. Res. 69:845-854.

- Johnson, D. W., Berg, J. N., Baldwin, M. A., Gallione, C. J., Marondel, I., Yoon, S. J., Stenzel, T. T., Speer, M., Pericak-Vance, M. A., Diamond, A., Guttmacher, A. E., Jackson, C. E., Attisano, L., Kucherlapati, R., Porteous, M. E. y Marchuk, D. A. (1996). Mutations in the activin receptor-like kinase 1 gene in hereditary haemorrhagic telangiectasia type 2. Nat. Genet. 13:189-195.

- Kato, A., Sakai, Y., Shioda, T., Kondo, T., Nakanishi, M. y Nagai, Y. (1996). Initiation of Sendai virus multiplication from transfected cDNA or RNA with negative or positive sense. Genes Cells 1:569-579.

- Kawana-Tachikawa, A., Tomizawa, M., Nunoya, J., Shioda, T., Kato, A., Nakayama, E. E., Nakamura, T., Nagai, Y. y Iwamoto, A. (2002). An efficient and versatile mammalian viral vector system for major histocompatibility complex class I/peptide complexes. J. Virol. 76:11982-11988.

- Kielian, M. y Rey, F. A. (2006). Virus membrane-fusion proteins: more than one way to make a hairpin. Nat. Rev. Microbiol. 4:67-76.

- Kingsbury, D. W. (1966). Newcastle disease virus RNA. II. Preferential synthesis of RNA complementary to parental viral RNA by chick embryo cells. J. Mol. Biol. 18:204-214.

- Kingsbury, D. W. (1985). Species classification problems in virus taxonomy. Intervirology 24:62-70.

- Kolakofsky, D., Vidal, S. y Curran, J.(1991). Paramyxovirus RNA synthesis and P gene expression, pp. 215-231. En The Paramyxoviruses, $8^{\mathrm{a}}$ ed., D. W. Kingsbury (ed.) Plenum Press, New York.

- Kolakofsky, D., Pelet, T., Garcin, D., Hausmann, S., Curran, J. y Roux, L. (1998). Paramyxovirus RNA synthesis and the requirement for hexamer genome length: the rule of six revisited. J. Virol. 72:891-899.

- Kraneveld, F. C. (1926). Over een in in Ned-Indie heershende Ziekte onder het Pluimves. Ned. Ind. Bladen. Diergeneseek. 38:448.

- Krishnamurthy, S. y Samal, S. K. (1998). Nucleotide sequences of the trailer, nucleocapsid protein gene and intergenic regions of Newcastle disease virus strain Beaudette C and completion of the entire genome sequence. J. Gen. Virol. 79 ( Pt 10):2419-2424. 
- Krishnamurthy, S., Huang, Z. y Samal, S. K. (2000). Recovery of a virulent strain of Newcastle disease virus from cloned cDNA: expression of a foreign gene results in growth retardation and attenuation. Virology 278:168-182.

- Krupinski, J., Kaluza, J., Kumar, P., Kumar, S. y Wang, J. M. (1994). Role of angiogenesis in patients with cerebral ischemic stroke. Stroke 25:1794-1798.

- Kumar, S., Ghellal, A., Li, C., Byrne, G., Haboubi, N., Wang, J. M. y Bundred, N. (1999). Breast carcinoma: vascular density determined using CD105 antibody correlates with tumor prognosis. Cancer Res. 59:856-861.

- Lamb, R. A. y Kolakofsky, D. (2001). Paramyxoviridae: The viruses and their replication., pp. 1305-1340. En Fields Virology, 4 ed., D.M.Knipe y P.M.Howley (eds.) Lippincott Williams \& Wilkins, Filadelfia.

- Lamb, R. A., Paterson, R. G. y Jardetzky, T. S. (2006). Paramyxovirus membrane fusion: lessons from the F and HN atomic structures. Virology 344:30-37.

- Lamb, R. A. y Parks, G. D. (2007). Paramyxoviridae: The viruses and their replication., pp. 1450-1496. En Fields Virology, 5th Edition, $4^{\text {a }}$ ed., D.M.Knipe y P.M.Howley (eds.) Lippincott Williams \& Wilkins, Filadelfia.

- Lamb, R. A. y Jardetzky, T. S. (2007). Structural basis of viral invasion: lessons from paramyxovirus F. Curr. Opin. Struct. Biol. 17:427-436.

- Lancaster, J. E. and D. J. Alexander. (1975). Newcastle desease virus and spread. Canada Department of Agriculture, Monografía $\mathrm{n}^{\mathrm{0}} 11$.

- Langedijk, J. P., Daus, F. J. y Van Oirschot, J. T. (1997). Sequence and structure alignment of Paramyxoviridae attachment proteins and discovery of enzymatic activity for a morbillivirus hemagglutinin. J. Virol. 71:6155-6167.

- Lastres, P., Bellon, T., Cabanas, C., Sanchez-Madrid, F., Acevedo, A., Gougos, A., Letarte, M. y Bernabeu, C. (1992). Regulated expression on human macrophages of endoglin, an ArgGly-Asp-containing surface antigen. Eur. J. Immunol. 22:393-397.

- Lastres, P., Martin-Pérez, J., Langa, C. y Bernabeu, C. (1994). Phosphorylation of the human-transforming-growth-factor-beta-binding protein endoglin. Biochem. J. 301 ( Pt 3):765768.

- Lastres, P., Letamendia, A., Zhang, H., Rius, C., Almendro, N., Raab, U., López, L. A., Langa, C., Fabra, A., Letarte, M. y Bernabeu, C. (1996). Endoglin modulates cellular responses to TGF-beta 1. J. Cell Biol. 133:1109-1121.

- Lawson, N. D., Stillman, E. A., Whitt, M. A. y Rose, J. K. (1995). Recombinant vesicular stomatitis viruses from DNA. Proc. Natl. Acad. Sci. U. S. A 92:4477-4481.

- Lee, K. J., Novella, I. S., Teng, M. N., Oldstone, M. B. y de la Torre, J. C. (2000). NP and L proteins of lymphocytic choriomeningitis virus (LCMV) are sufficient for efficient transcription and replication of LCMV genomic RNA analogs. J. Virol. 74:3470-3477.

- Letamendia, A., Lastres, P., Botella, L. M., Raab, U., Langa, C., Velasco, B., Attisano, L. y Bernabeu, C. (1998a). Role of endoglin in cellular responses to transforming growth factorbeta. A comparative study with betaglycan. J. Biol. Chem. 273:33011-33019.

- Letamendia, A., Lastres, P., Almendro, N., Raab, U., Buhring, H. J., Kumar, S. y Bernabeu, C. (1998b). Endoglin, a component of the TGF-beta receptor system, is a differentiation marker of human choriocarcinoma cells. Int. J. Cancer 76:541-546. 
- Levine, R. J., Lam, C., Qian, C., Yu, K. F., Maynard, S. E., Sachs, B. P., Sibai, B. M., Epstein, F. H., Romero, R., Thadhani, R. y Karumanchi, S. A. (2006). Soluble endoglin and other circulating antiangiogenic factors in preeclampsia. N. Engl. J. Med. 355:992-1005.

- Li, C., Guo, B., Wilson, P. B., Stewart, A., Byrne, G., Bundred, N. y Kumar, S. (2000). Plasma levels of soluble CD105 correlate with metastasis in patients with breast cancer. Int. J. Cancer 89:122-126.

- Li, C., Hampson, I. N., Hampson, L., Kumar, P., Bernabeu, C. y Kumar, S. (2000). CD105 antagonizes the inhibitory signaling of transforming growth factor beta1 on human vascular endothelial cells. FASEB J. 14:55-64.

- Li, D. Y., Sorensen, L. K., Brooke, B. S., Urness, L. D., Davis, E. C., Taylor, D. G., Boak, B. B. y Wendel, D. P. (1999). Defective angiogenesis in mice lacking endoglin. Science 284:15341537.

- Li, J., Melanson, V. R., Mirza, A. M. y Iorio, R. M. (2005). Decreased dependence on receptor recognition for the fusion promotion activity of L289A-mutated Newcastle disease virus fusion protein correlates with a monoclonal antibody-detected conformational change. J. Virol. 79:1180-1190.

- Liu, Y. L., Hu, S. L., Zhang, Y. M., Sun, S. J., Romer-Oberdorfer, A., Veits, J., Wu, Y. T., Wan, H. Q. y Liu, X. F. (2007). Generation of a velogenic Newcastle disease virus from cDNA and expression of the green fluorescent protein. Arch. Virol. 152:1241-1249.

- Locke, D. P., Sellers, H. S., Crawford, J. M., Schultz-Cherry, S., King, D. J., Meinersmann, R. J. y Seal, B. S. (2000). Newcastle disease virus phosphoprotein gene analysis and transcriptional editing in avian cells. Virus Res. 69:55-68.

- López-Novoa, J. M. (2007). Soluble endoglin is an accurate predictor and a pathogenic molecule in pre-eclampsia. Nephrol. Dial. Transplant. 22:712-714.

- Lorence, R. M., Roberts, M. S., O'Neil, J. D., Groene, W. S., Miller, J. A., Mueller, S. N. y Bamat, M. K. (2007). Phase 1 clinical experience using intravenous administration of PV701, an oncolytic Newcastle disease virus. Curr. Cancer Drug Targets. 7:157-167.

- Lowry, O. H., Rosebrough, N. J., Farr, A. L. y Randall, R. J. (1951). Protein measurement with the Folin phenol reagent. J. Biol. Chem. 193:265-275.

- Lu, B., Ma, C. H., Brazas, R. y Jin, H. (2002). The major phosphorylation sites of the respiratory syncytial virus phosphoprotein are dispensable for virus replication in vitro. J. Virol. 76:10776-10784.

- Luan, P. y Glaser, M. (1994). Formation of membrane domains by the envelope proteins of vesicular stomatitis virus. Biochemistry 33:4483-4489.

- Luan, P., Yang, L. y Glaser, M. (1995). Formation of membrane domains created during the budding of vesicular stomatitis virus. A model for selective lipid and protein sorting in biological membranes. Biochemistry 34:9874-9883.

- Luft, F. C. (2006). Soluble endoglin (sEng) joins the soluble fms-like tyrosine kinase (sFlt) receptor as a pre-eclampsia molecule. Nephrol. Dial. Transplant. 21:3052-3054.

- Lupas, A. (1996). Coiled coils: new structures and new functions. Trends Biochem. Sci. 21:375382.

- Luque, L. E. y Russell, C. J. (2007). Spring-loaded heptad repeat residues regulate the expression and activation of paramyxovirus fusion protein. J. Virol. 81:3130-3141. 
- Luytjes, W., Krystal, M., Enami, M., Pavin, J. D. y Palese, P. (1989). Amplification, expression, and packaging of foreign gene by influenza virus. Cell 59:1107-1113.

- Mahon, P. J., Mirza, A. M., Musich, T. A. y Iorio, R. M. (2008). Engineered intermonomeric disulfide bonds in the globular domain of Newcastle disease virus hemagglutinin-neuraminidase protein: implications for the mechanism of fusion promotion. J. Virol. 82:10386-10396.

- Marcos, F., Ferreira, L., Cros, J., Park, M. S., Nakaya, T., García-Sastre, A. y Villar, E. (2005). Mapping of the RNA promoter of Newcastle disease virus. Virology 331:396-406.

- Markovic, I., Stantchev, T. S., Fields, K. H., Tiffany, L. J., Tomic, M., Weiss, C. D., Broder, C. C., Strebel, K. y Clouse, K. A. (2004). Thiol/disulfide exchange is a prerequisite for CXCR4-tropic HIV-1 envelope-mediated T-cell fusion during viral entry. Blood 103:1586-1594.

- Markwell, M. A., Haas, S. M., Bieber, L. L. y Tolbert, N. E. (1978). A modification of the Lowry procedure to simplify protein determination in membrane and lipoprotein samples. Anal. Biochem. 87:206-210.

- Martínez-Sobrido, L., Gitiban, N., Fernández-Sesma, A., Cros, J., Mertz, S. E., Jewell, N. A., Hammond, S., Flano, E., Durbin, R. K., García-Sastre, A. y Durbin, J. E. (2006). Protection against respiratory syncytial virus by a recombinant Newcastle disease virus vector. $J$. Virol. 80:1130-1139.

- Mavrakis, M., Kolesnikova, L., Schoehn, G., Becker, S. y Ruigrok, R. W. (2002). Morphology of Marburg virus NP-RNA. Virology 296:300-307.

- Mayo, M. A. (2002). A summary of taxonomic changes recently approved by ICTV. Arch. Virol. 147:1655-1663.

- McAllister, K. A., Grogg, K. M., Johnson, D. W., Gallione, C. J., Baldwin, M. A., Jackson, C. E., Helmbold, E. A., Markel, D. S., McKinnon, W. C., Murrell, J. y • (1994). Endoglin, a TGF-beta binding protein of endothelial cells, is the gene for hereditary haemorrhagic telangiectasia type 1. Nat. Genet. 8:345-351.

- McGinnes, L., Sergel, T. y Morrison, T. (1993). Mutations in the transmembrane domain of the HN protein of Newcastle disease virus affect the structure and activity of the protein. Virology 196:101-110.

- McGinnes, L. W., Sergel, T., Chen, H., Hamo, L., Schwertz, S., Li, D. y Morrison, T. G. (2001). Mutational analysis of the membrane proximal heptad repeat of the Newcastle disease virus fusion protein. Virology 289:343-352.

- Mebatsion, T., Verstegen, S., de Vaan, L. T., Romer-Oberdorfer, A. y Schrier, C. C. (2001). A recombinant Newcastle disease virus with low-level $\mathrm{V}$ protein expression is immunogenic and lacks pathogenicity for chicken embryos. J. Virol. 75:420-428.

- Mebatsion, T., Koolen, M. J., de Vaan, L. T., de Haas, N., Braber, M., Romer-Oberdorfer, A., van den, E. P. y van der, M. P. (2002). Newcastle disease virus (NDV) marker vaccine: an immunodominant epitope on the nucleoprotein gene of NDV can be deleted or replaced by a foreign epitope. J. Virol. 76:10138-10146.

- Mebatsion, T., de Vaan, L. T., de Haas, N., Romer-Oberdorfer, A. y Braber, M. (2003). Identification of a mutation in editing of defective Newcastle disease virus recombinants that modulates P-gene mRNA editing and restores virus replication and pathogenicity in chicken embryos. J. Virol. 77:9259-9265.

- Melanson, V. R. y Iorio, R. M. (2006). Addition of N-glycans in the stalk of the Newcastle disease virus HN protein blocks its interaction with the F protein and prevents fusion. J. Virol. 80:623-633. 
- Mibayashi, M., Martínez-Sobrido, L., Loo, Y. M., Cardenas, W. B., Gale, M., Jr. y GarcíaSastre, A. (2007). Inhibition of retinoic acid-inducible gene I-mediated induction of beta interferon by the NS1 protein of influenza A virus. J. Virol. 81:514-524.

- Mirza, A. M., Deng, R. y Iorio, R. M. (1994). Site-directed mutagenesis of a conserved hexapeptide in the paramyxovirus hemagglutinin-neuraminidase glycoprotein: effects on antigenic structure and function. J. Virol. 68:5093-5099.

- Morrison, T. G., Peeples, M. E. y McGinnes, L. W. (1987). Conformational change in a viral glycoprotein during maturation due to disulfide bond disruption. Proc. Natl. Acad. Sci. U. S. A 84:1020-1024.

- Morrison, T. G. (2003). Structure and function of a paramyxovirus fusion protein. Biochim. Biophys. Acta 1614:73-84.

- Muhlberger, E., Lotfering, B., Klenk, H. D. y Becker, S. (1998). Three of the four nucleocapsid proteins of Marburg virus, NP, VP35, and L, are sufficient to mediate replication and transcription of Marburg virus-specific monocistronic minigenomes. J. Virol. 72:8756-8764.

- Muhlberger, E., Weik, M., Volchkov, V. E., Klenk, H. D. y Becker, S. (1999). Comparison of the transcription and replication strategies of marburg virus and Ebola virus by using artificial replication systems. J. Virol. 73:2333-2342.

- Muñoz-Barroso, I., Cobaleda, C., Zhadan, G., Shnyrov, V. y Villar, E. (1997). Dynamic properties of Newcastle Disease Virus envelope and their relations with viral hemagglutininneuraminidase membrane glycoprotein. Biochim. Biophys. Acta 1327:17-31.

- Nagai, Y. y Klenk, H. D. (1977). Activation of precursors to both glycoporteins of Newcastle disease virus by proteolytic cleavage. Virology 77:125-134.

- Nakaya, T., Cros, J., Park, M. S., Nakaya, Y., Zheng, H., Sagrera, A., Villar, E., GarcíaSastre, A. y Palese, P. (2001). Recombinant Newcastle disease virus as a vaccine vector. $J$. Virol. 75:11868-11873.

- Nakaya, Y., Nakaya, T., Park, M. S., Cros, J., Imanishi, J., Palese, P. y García-Sastre, A. (2004). Induction of cellular immune responses to simian immunodeficiency virus gag by two recombinant negative-strand RNA virus vectors. J. Virol. 78:9366-9375.

- Neumann, G., Watanabe, T., Ito, H., Watanabe, S., Goto, H., Gao, P., Hughes, M., Pérez, D. R., Donis, R., Hoffmann, E., Hobom, G. y Kawaoka, Y. (1999). Generation of influenza A viruses entirely from cloned cDNAs. Proc. Natl. Acad. Sci. U. S. A 96:9345-9350.

- Neumann, G., Feldmann, H., Watanabe, S., Lukashevich, I. y Kawaoka, Y. (2002). Reverse genetics demonstrates that proteolytic processing of the Ebola virus glycoprotein is not essential for replication in cell culture. J. Virol. 76:406-410.

- Neumann, G., Fujii, K., Kino, Y. y Kawaoka, Y. (2005). An improved reverse genetics system for influenza A virus generation and its implications for vaccine production. Proc. Natl. Acad. Sci. U. S. A 102:16825-16829.

- Niwa, H., Yamamura, K. y Miyazaki, J. (1991). Efficient selection for high-expression transfectants with a novel eukaryotic vector. Gene 108:193-199.

- Obreo, J., Diez-Marques, L., Lamas, S., Duwell, A., Eleno, N., Bernabeu, C., Pandiella, A., López-Novoa, J. M. y Rodríguez-Barbero, A. (2004). Endoglin expression regulates basal and TGF-beta1-induced extracellular matrix synthesis in cultured L6E9 myoblasts. Cell Physiol Biochem. 14:301-310. 
- Oku, N., Nojima, S. y Inoue, K. (1981). Studies on the interaction of Sendai virus with liposomal membranes. Sendai virus-induced agglutination of liposomes containing glycophorin. Biochim. Biophys. Acta 646:36-42.

- Oku, N., Inoue, K., Nojima, S., Sekiya, T. y Nozawa, Y. (1982). Electron microscopic study on the interaction of Sendai virus with liposomes containing glycophorin. Biochim. Biophys. Acta 691:91-96.

- Oku, N., Nojima, S. y Inoue, K. (1982). Studies on the interaction of HVJ (Sendai Virus) with liposomal membranes. HVJ-induced permeability increase of liposomes containing glycophorin. Virology 116:419-427.

- Palese, P., Zheng, H., Engelhardt, O. G., Pleschka, S. y García-Sastre, A. (1996). Negativestrand RNA viruses: genetic engineering and applications. Proc. Natl. Acad. Sci. U. S. A 93:11354-11358.

- Panda, A., Huang, Z., Elankumaran, S., Rockemann, D. D. y Samal, S. K. (2004a). Role of fusion protein cleavage site in the virulence of Newcastle disease virus. Microb. Pathog. 36:110 .

- Panda, A., Elankumaran, S., Krishnamurthy, S., Huang, Z. y Samal, S. K. (2004b). Loss of $\mathrm{N}$-linked glycosylation from the hemagglutinin-neuraminidase protein alters virulence of Newcastle disease virus. J. Virol. 78:4965-4975.

- Pantua, H. D., McGinnes, L. W., Peeples, M. E. y Morrison, T. G. (2006). Requirements for the assembly and release of Newcastle disease virus-like particles. J. Virol. 80:11062-11073.

- Park, K. H., Huang, T., Correia, F. F. y Krystal, M. (1991). Rescue of a foreign gene by Sendai virus. Proc. Natl. Acad. Sci. U. S. A 88:5537-5541.

- Park, M. S., García-Sastre, A., Cros, J. F., Basler, C. F. y Palese, P. (2003). Newcastle disease virus V protein is a determinant of host range restriction. J. Virol. 77:9522-9532.

- Park, M. S., Shaw, M. L., Muñoz-Jordan, J., Cros, J. F., Nakaya, T., Bouvier, N., Palese, P., García-Sastre, A. y Basler, C. F. (2003). Newcastle disease virus (NDV)-based assay demonstrates interferon-antagonist activity for the NDV V protein and the Nipah virus V, W, and C proteins. J. Virol. 77:1501-1511.

- Park, M. S., Steel, J., García-Sastre, A., Swayne, D. y Palese, P. (2006). Engineered viral vaccine constructs with dual specificity: avian influenza and Newcastle disease. Proc. Natl. Acad. Sci. U. S. A 103:8203-8208.

- Parvin, J. D., Palese, P., Honda, A., Ishihama, A. y Krystal, M. (1989). Promoter analysis of influenza virus RNA polymerase. J. Virol. 63:5142-5152.

- Paterson, R. G., Russell, C. J. y Lamb, R. A. (2000). Fusion protein of the paramyxovirus SV5: destabilizing and stabilizing mutants of fusion activation. Virology 270:17-30.

- Pattnaik, A. K. y Wertz, G. W. (1990). Replication and amplification of defective interfering particle RNAs of vesicular stomatitis virus in cells expressing viral proteins from vectors containing cloned cDNAs. J. Virol. 64:2948-2957.

- Pecora, A. L., Rizvi, N., Cohen, G. I., Meropol, N. J., Sterman, D., Marshall, J. L., Goldberg, S., Gross, P., O'Neil, J. D., Groene, W. S., Roberts, M. S., Rabin, H., Bamat, M. K. y Lorence, R. M. (2002). Phase I trial of intravenous administration of PV701, an oncolytic virus, in patients with advanced solid cancers. J. Clin. Oncol. 20:2251-2266. 
- Peeples, M. E. y Bratt, M. A. (1982). UV irradiation analysis of complementation between, and replication of, RNA-negative temperature-sensitive mutants of Newcastle disease virus. J. Virol. 41:965-973.

- Peeters, B., Verbruggen, P., Nelissen, F. y de Leeuw, O. (2004). The P gene of Newcastle disease virus does not encode an accessory X protein. J. Gen. Virol. 85:2375-2378.

- Peeters, B. P., de Leeuw, O. S., Koch, G. y Gielkens, A. L. (1999). Rescue of Newcastle disease virus from cloned cDNA: evidence that cleavability of the fusion protein is a major determinant for virulence. J. Virol. 73:5001-5009.

- Peeters, B. P., Gruijthuijsen, Y. K., de Leeuw, O. S. y Gielkens, A. L. (2000). Genome replication of Newcastle disease virus: involvement of the rule-of-six. Arch. Virol. 145:18291845.

- Peeters, B. P., de Leeuw, O. S., Verstegen, I., Koch, G. y Gielkens, A. L. (2001). Generation of a recombinant chimeric Newcastle disease virus vaccine that allows serological differentiation between vaccinated and infected animals. Vaccine 19:1616-1627.

- Plemper, R. K. y Compans, R. W. (2003). Mutations in the putative HR-C region of the measles virus F2 glycoprotein modulate syncytium formation. J. Virol. 77:4181-4190.

- Porotto, M., Fornabaio, M., Kellogg, G. E. y Moscona, A. (2007). A second receptor binding site on human parainfluenza virus type 3 hemagglutinin-neuraminidase contributes to activation of the fusion mechanism. J. Virol. 81:3216-3228.

- Puhler, F., Willuda, J., Puhlmann, J., Mumberg, D., Romer-Oberdorfer, A. y Beier, R. (2008). Generation of a recombinant oncolytic Newcastle disease virus and expression of a full IgG antibody from two transgenes. Gene Ther. 15:371-383.

- Quackenbush, E. J., Gougos, A., Baumal, R. y Letarte, M. (1986). Differential localization within human kidney of five membrane proteins expressed on acute lymphoblastic leukemia cells. J. Immunol. 136:118-124.

- Raab, U., Velasco, B., Lastres, P., Letamendia, A., Cales, C., Langa, C., Tapia, E., LópezBote, J. P., Paez, E. y Bernabeu, C. (1999). Expression of normal and truncated forms of human endoglin. Biochem. J. 339 ( Pt 3):579-588.

- Radecke, F., Spielhofer, P., Schneider, H., Kaelin, K., Huber, M., Dotsch, C., Christiansen, G. y Billeter, M. A. (1995). Rescue of measles viruses from cloned DNA. EMBO J. 14:57735784.

- Reid, A. H., Fanning, T. G., Hultin, J. V. y Taubenberger, J. K. (1999). Origin and evolution of the 1918 "Spanish" influenza virus hemagglutinin gene. Proc. Natl. Acad. Sci. U. S. A 96:1651-1656.

- Richman, A. V., Pedreira, F. A. y Tauraso, N. M. (1971). Attempts to demonstrate hemagglutination and hemadsorption by respiratory syncytial virus. Appl. Microbiol. 21:10991100 .

- Roberts, A. y Rose, J. K. (1998). Recovery of negative-strand RNA viruses from plasmid DNAs: a positive approach revitalizes a negative field. Virology 247:1-6.

- Roberts, P. C. y Compans, R. W. (1998). Host cell dependence of viral morphology. Proc. Natl. Acad. Sci. U. S. A 95:5746-5751.

- Rodríguez-Barbero, A., Obreo, J., Eleno, N., Rodríguez-Pena, A., Duwel, A., Jerkic, M., Sanchez-Rodríguez, A., Bernabeu, C. y López-Novoa, J. M. (2001). Endoglin expression in 
human and rat mesangial cells and its upregulation by TGF-beta1. Biochem. Biophys. Res. Commun. 282:142-147.

- Rodríguez-Barbero, A., Obreo, J., Alvarez-Muñoz, P., Pandiella, A., Bernabéu, C. y LópezNovoa, J. M. (2006). Endoglin modulation of TGF-beta1-induced collagen synthesis is dependent on ERK1/2 MAPK activation. Cell Physiol Biochem. 18:135-142.

- Rodríguez-Peña, A., Prieto, M., Duwel, A., Rivas, J. V., Eleno, N., Pérez-Barriocanal, F., Arévalo, M., Smith, J. D., Vary, C. P., Bernabéu, C. y López-Novoa, J. M. (2001). Upregulation of endoglin, a TGF-beta-binding protein, in rats with experimental renal fibrosis induced by renal mass reduction. Nephrol. Dial. Transplant. 16 Suppl 1:34-39.

- Rodríguez-Pena, A., Eleno, N., Duwell, A., Arevalo, M., Pérez-Barriocanal, F., Flores, O., Docherty, N., Bernabéu, C., Letarte, M. y López-Novoa, J. M. (2002). Endoglin upregulation during experimental renal interstitial fibrosis in mice. Hypertension 40:713-720.

- Romer-Oberdorfer, A., Mundt, E., Mebatsion, T., Buchholz, U. J. y Mettenleiter, T. C. (1999). Generation of recombinant lentogenic Newcastle disease virus from cDNA. J. Gen. Virol. 80 ( Pt 11):2987-2995.

- Romer-Oberdorfer, A., Werner, O., Veits, J., Mebatsion, T. y Mettenleiter, T. C. (2003). Contribution of the length of the HN protein and the sequence of the F protein cleavage site to Newcastle disease virus pathogenicity. J. Gen. Virol. 84:3121-3129.

- Romer-Oberdorfer, A., Veits, J., Werner, O. y Mettenleiter, T. C. (2006). Enhancement of pathogenicity of Newcastle disease virus by alteration of specific amino acid residues in the surface glycoproteins F and HN. Avian Dis. 50:259-263.

- Romer-Oberdorfer, A., Veits, J., Helferich, D. y Mettenleiter, T. C. (2008). Level of protection of chickens against highly pathogenic H5 avian influenza virus with Newcastle disease virus based live attenuated vector vaccine depends on homology of H5 sequence between vaccine and challenge virus. Vaccine 26:2307-2313.

- Rott, R., Waterson, A. P. y Reda, I. M. (1963). Characterization of soluble antigens from cells with Sendai and Newcastle desease virus. Virology 21:663-665.

- Rott, R. y Klenk, H. D.(1988). Molecular basis of infectivity and pathogenicity of Newcastle desease virus, pp. 98-112. En Newcastle desease, D. J. Alexander (ed.) Kluver, Norwell.

- Rout, S. N. y Samal, S. K. (2008). The large polymerase protein is associated with the virulence of Newcastle disease virus. J. Virol. 82:7828-7836.

- Roy-Chaudhury, P., Simpson, J. G. y Power, D. A. (1997). Endoglin, a transforming growth factor-beta-binding protein, is upregulated in chronic progressive renal disease. Exp. Nephrol. 5:55-60.

- Rulo, H. F., Westphal, J. R., van de Kerkhof, P. C., de Waal, R. M., van Vlijmen, I. M. y Ruiter, D. J. (1995) . Expression of endoglin in psoriatic involved and uninvolved skin. J. Dermatol. Sci. 10:103-109.

- Russell, C. J., Jardetzky, T. S. y Lamb, R. A. (2001). Membrane fusion machines of paramyxoviruses: capture of intermediates of fusion. EMBO J. 20:4024-4034.

- Russell, C. J., Kantor, K. L., Jardetzky, T. S. y Lamb, R. A. (2003). A dual-functional paramyxovirus $\mathrm{F}$ protein regulatory switch segment: activation and membrane fusion. J. Cell Biol. 163:363-374.

- Russell, C. J. y Luque, L. E. (2006). The structural basis of paramyxovirus invasion. Trends Microbiol. 14:243-246. 
- San Roman, K., Villar, E. y Muñoz-Barroso, I. (1999). Acidic pH enhancement of the fusion of Newcastle disease virus with cultured cells. Virology 260:329-341.

- Sanchez-Elsner, T., Botella, L. M., Velasco, B., Langa, C. y Bernabéu, C. (2002). Endoglin expression is regulated by transcriptional cooperation between the hypoxia and transforming growth factor-beta pathways. J. Biol. Chem. 277 :43799-43808.

- Sanderson, C. M., Avalos, R., Kundu, A. y Nayak, D. P. (1995). Interaction of Sendai viral F, $\mathrm{HN}$, and M proteins with host cytoskeletal and lipid components in Sendai virus-infected BHK cells. Virology 209:701-707.

- Schmitt, A. P. y Lamb, R. A. (2004). Escaping from the cell: assembly and budding of negative-strand RNA viruses. Curr. Top. Microbiol. Immunol. 283:145-196.

- Schneider, U., Schwemmle, M. y Staeheli, P. (2005). Genome trimming: a unique strategy for replication control employed by Borna disease virus. Proc. Natl. Acad. Sci. U. S. A 102:34413446.

- Schnell, M. J., Mebatsion, T. y Conzelmann, K. K. (1994). Infectious rabies viruses from cloned cDNA. EMBO J. 13:4195-4203.

- Schuy, W., Garten, W., Linder, D. y Klenk, H. D. (1984). The carboxyterminus of the hemagglutinin-neuraminidase of Newcastle disease virus is exposed at the surface of the viral envelope. Virus Res. 1:415-426.

- Seal, B. S., King, D. J., Locke, D. P., Senne, D. A. y Jackwood, M. W. (1998). Phylogenetic relationships among highly virulent Newcastle disease virus isolates obtained from exotic birds and poultry from 1989 to 1996. J. Clin. Microbiol. 36:1141-1145.

- Seal, B. S., King, D. J. y Meinersmann, R. J. (2000). Molecular evolution of the Newcastle disease virus matrix protein gene and phylogenetic relationships among the paramyxoviridae. Virus Res. 66:1-11.

- Seal, B. S., Crawford, J. M., Sellers, H. S., Locke, D. P. y King, D. J. (2002). Nucleotide sequence analysis of the Newcastle disease virus nucleocapsid protein gene and phylogenetic relationships among the Paramyxoviridae. Virus Res. 83:119-129.

- Seon, B. K., Matsuno, F., Haruta, Y., Kondo, M. y Barcos, M. (1997). Long-lasting complete inhibition of human solid tumors in SCID mice by targeting endothelial cells of tumor vasculature with antihuman endoglin immunotoxin. Clin. Cancer Res. 3:1031-1044.

- Sergel-Germano, T., McQuain, C. y Morrison, T. (1994). Mutations in the fusion peptide and heptad repeat regions of the Newcastle disease virus fusion protein block fusion. J. Virol. 68:7654-7658.

- Sergel, T., McGinnes, L. W., Peeples, M. E. y Morrison, T. G. (1993). The attachment function of the Newcastle disease virus hemagglutinin-neuraminidase protein can be separated from fusion promotion by mutation. Virology 193:717-726.

- Sergel, T. A., McGinnes, L. W. y Morrison, T. G. (2000). A single amino acid change in the Newcastle disease virus fusion protein alters the requirement for HN protein in fusion. J. Virol. 74:5101-5107.

- Sergel, T. A., McGinnes, L. W. y Morrison, T. G. (2001). Mutations in the fusion peptide and adjacent heptad repeat inhibit folding or activity of the Newcastle disease virus fusion protein. $J$. Virol. 75:7934-7943.

- Serra, R. y Moses, H. L. (1996). Tumor suppressor genes in the TGF-beta signaling pathway? Nat. Med. 2:390-391. 
- Shimizu, K. y Isida, N. (1975) . The smallest protein of Sendi virus: its candidate function of binding nucleocaspsid to envelope. Virology 67:427-437.

- Shnyrova, A. V., Ayllón, J., Mikhalyov, I. I., Villar, E., Zimmerberg, J. y Frolov, V. A. (2007). Vesicle formation by self-assembly of membrane-bound matrix proteins into a fluidlike budding domain. J. Cell Biol. 179:627-633.

- Shovlin, C. L. (1997). Molecular defects in rare bleeding disorders: hereditary haemorrhagic telangiectasia. Thromb. Haemost. 78:145-150.

- Sidhu, M. S., Chan, J., Kaelin, K., Spielhofer, P., Radecke, F., Schneider, H., Masurekar, M., Dowling, P. C., Billeter, M. A. y Udem, S. A. (1995). Rescue of synthetic measles virus minireplicons: measles genomic termini direct efficient expression and propagation of a reporter gene. Virology 208:800-807.

- Skehel, J. J. y Wiley, D. C. (1998). Coiled coils in both intracellular vesicle and viral membrane fusion. Cell 95:871-874.

- Smith, G. L., Mackett, M. y Moss, B. (1983). Infectious vaccinia virus recombinants that express hepatitis B virus surface antigen. Nature 302:490-495.

- St Jacques, S., Cymerman, U., Pece, N. y Letarte, M. (1994). Molecular characterization and in situ localization of murine endoglin reveal that it is a transforming growth factor-beta binding protein of endothelial and stromal cells. Endocrinology 134:2645-2657.

- Stenback, W. A. y Durand, D. P. (1963). Host influence on the density of Newcastle desease virus (NDV). Virology 20:545-551.

- Steward, M., Vipond, I. B., Millar, N. S. y Emmerson, P. T. (1993). RNA editing in Newcastle disease virus. J. Gen. Virol. 74 ( Pt 12):2539-2547.

- Stone-Hulslander, J. y Morrison, T. G. (1999). Mutational analysis of heptad repeats in the membrane-proximal region of Newcastle disease virus HN protein. J. Virol. 73:3630-3637.

- Stricker, R., Mottet, G. y Roux, L. (1994). The Sendai virus matrix protein appears to be recruited in the cytoplasm by the viral nucleocapsid to function in viral assembly and budding. $J$. Gen. Virol. 75 ( Pt 5):1031-1042.

- Sun, M., Fuentes, S. M., Timani, K., Sun, D., Murphy, C., Lin, Y., August, A., Teng, M. N. y He, B. (2008). Akt plays a critical role in replication of nonsegmented negative-stranded RNA viruses. J. Virol. 82:105-114.

- Suzuki, Y., Suzuki, T., Matsunaga, M. y Matsumoto, M. (1985). Gangliosides as paramyxovirus receptor. Structural requirement of sialo-oligosaccharides in receptors for hemagglutinating virus of Japan (Sendai virus) and Newcastle disease virus. J. Biochem. (Tokyo) 97:1189-1199.

- Swayne, D. E., Suarez, D. L., Schultz-Cherry, S., Tumpey, T. M., King, D. J., Nakaya, T., Palese, P. y García-Sastre, A. (2003). Recombinant paramyxovirus type 1-avian influenza-H7 virus as a vaccine for protection of chickens against influenza and Newcastle disease. Avian Dis. 47:1047-1050.

- Szewczyk, B., Laver, W. G. y Summers, D. F. (1988). Purification, thioredoxin renaturation, and reconstituted activity of the three subunits of the influenza A virus RNA polymerase. Proc. Natl. Acad. Sci. U. S. A 85:7907-7911.

- Thorpe, P. E. y Burrows, F. J. (1995). Antibody-directed targeting of the vasculature of solid tumors. Breast Cancer Res. Treat. 36:237-251. 
- Toyoda, T., Sakaguchi, T., Hirota, H., Gotoh, B., Kuma, K., Miyata, T. y Nagai, Y. (1989). Newcastle disease virus evolution. II. Lack of gene recombination in generating virulent and avirulent strains. Virology 169:273-282.

- Veits, J., Wiesner, D., Fuchs, W., Hoffmann, B., Granzow, H., Starick, E., Mundt, E., Schirrmeier, H., Mebatsion, T., Mettenleiter, T. C. y Romer-Oberdorfer, A. (2006). Newcastle disease virus expressing H5 hemagglutinin gene protects chickens against Newcastle disease and avian influenza. Proc. Natl. Acad. Sci. U. S. A 103:8197-8202.

- Veits, J., Romer-Oberdorfer, A., Helferich, D., Durban, M., Suezer, Y., Sutter, G. y Mettenleiter, T. C. (2008). Protective efficacy of several vaccines against highly pathogenic H5N1 avian influenza virus under experimental conditions. Vaccine 26:1688-1696.

- Venkatesha, S., Toporsian, M., Lam, C., Hanai, J., Mammoto, T., Kim, Y. M., Bdolah, Y., Lim, K. H., Yuan, H. T., Libermann, T. A., Stillman, I. E., Roberts, D., D'Amore, P. A., Epstein, F. H., Sellke, F. W., Romero, R., Sukhatme, V. P., Letarte, M. y Karumanchi, S. A. (2006). Soluble endoglin contributes to the pathogenesis of preeclampsia. Nat. Med. 12:642649.

- Vigil, A., Park, M. S., Martínez, O., Chua, M. A., Xiao, S., Cros, J. F., Martínez-Sobrido, L., Woo, S. L. y García-Sastre, A. (2007). Use of reverse genetics to enhance the oncolytic properties of Newcastle disease virus. Cancer Res. 67:8285-8292.

- Vigil, A., Martínez, O., Chua, M. A. y García-Sastre, A. (2008). Recombinant Newcastle disease virus as a vaccine vector for cancer therapy. Mol. Ther. 16:1883-1890.

- Volchkov, V. E., Volchkova, V. A., Muhlberger, E., Kolesnikova, L. V., Weik, M., Dolnik, O. y Klenk, H. D. (2001). Recovery of infectious Ebola virus from complementary DNA: RNA editing of the GP gene and viral cytotoxicity. Science 291:1965-1969.

- Wang, J. M., Kumar, S., Pye, D., van Agthoven, A. J., Krupinski, J. y Hunter, R. D. (1993). A monoclonal antibody detects heterogeneity in vascular endothelium of tumours and normal tissues. Int. J. Cancer 54:363-370.

- Wang, J. M., Wilson, P. B., Kumar, S., Pye, D. y Hunter, R. D. (1994). Quantitation of endothelial cell specific protein E-9 employing a single monoclonal antibody in an indirect sandwich ELISA. J. Immunol. Methods 171:55-64.

- Wang, J. M., Kumar, S., Pye, D., Haboubi, N. y al Nakib, L. (1994). Breast carcinoma: comparative study of tumor vasculature using two endothelial cell markers. J. Natl. Cancer Inst. 86:386-388.

- Waning, D. L., Russell, C. J., Jardetzky, T. S. y Lamb, R. A. (2004). Activation of a paramyxovirus fusion protein is modulated by inside-out signaling from the cytoplasmic tail. Proc. Natl. Acad. Sci. U. S. A 101:9217-9222.

- Waterson, A. P. (1962). Two kinds of myxovirus. Nature 193:1163-1164.

- West, D. S., Sheehan, M. S., Segeleon, P. K. y Dutch, R. E. (2005). Role of the simian virus 5 fusion protein N-terminal coiled-coil domain in folding and promotion of membrane fusion. $J$. Virol. 79:1543-1551.

- Whelan, S. P., Ball, L. A., Barr, J. N. y Wertz, G. T. (1995). Efficient recovery of infectious vesicular stomatitis virus entirely from cDNA clones. Proc. Natl. Acad. Sci. U. S. A 92:83888392.

- Whelan, S. P., Barr, J. N. y Wertz, G. W. (2004). Transcription and replication of nonsegmented negative-strand RNA viruses. Curr. Top. Microbiol. Immunol. 283:61-119. 
- Wu, P. S., Ledeen, R. W., Udem, S. y Isaacson, Y. A. (1980). Nature of the Sendai virus receptor: glycoprotein versus ganglioside. J. Virol. 33:304-310.

- Wyatt, L. S., Moss, B. y Rozenblatt, S. (1995). Replication-deficient vaccinia virus encoding bacteriophage T7 RNA polymerase for transient gene expression in mammalian cells. Virology 210:202-205.

- Yamashita, H., Ichijo, H., Grimsby, S., Moren, A., ten Dijke, P. y Miyazono, K. (1994). Endoglin forms a heteromeric complex with the signaling receptors for transforming growth factor-beta. J. Biol. Chem. 269:1995-2001.

- Yan, Y. y Samal, S. K. (2008). Role of intergenic sequences in Newcastle disease virus RNA transcription and pathogenesis. J. Virol. 82:1323-1331.

- Yin, H. S., Paterson, R. G., Wen, X., Lamb, R. A. y Jardetzky, T. S. (2005). Structure of the uncleaved ectodomain of the paramyxovirus (hPIV3) fusion protein. Proc. Natl. Acad. Sci. U. S. A 102:9288-9293.

- Yin, H. S., Wen, X., Paterson, R. G., Lamb, R. A. y Jardetzky, T. S. (2006). Structure of the parainfluenza virus 5 F protein in its metastable, prefusion conformation. Nature 439:38-44.

- Yoshida, T., Takao, S., Kiyotani, K. y Sakaguchi, T. (1989). Endoproteolytic activation of Newcastle disease virus fusion proteins requires an intracellular acidic environment. Virology 170:571-574.

- Yuan, P., Thompson, T. B., Wurzburg, B. A., Paterson, R. G., Lamb, R. A. y Jardetzky, T. S. (2005). Structural studies of the parainfluenza virus 5 hemagglutinin-neuraminidase tetramer in complex with its receptor, sialyllactose. Structure. 13:803-815.

- Yusoff, K., Millar, N. S., Chambers, P. y Emmerson, P. T. (1987). Nucleotide sequence analysis of the $\mathrm{L}$ gene of Newcastle disease virus: homologies with Sendai and vesicular stomatitis viruses. Nucleic Acids Res. 15:3961-3976.

- Zaitsev, V., von Itzstein, M., Groves, D., Kiefel, M., Takimoto, T., Portner, A. y Taylor, G. (2004). Second sialic acid binding site in Newcastle disease virus hemagglutinin-neuraminidase: implications for fusion. J. Virol. 78:3733-3741.

- Zhang, H., Shaw, A. R., Mak, A. y Letarte, M. (1996). Endoglin is a component of the transforming growth factor (TGF)-beta receptor complex of human pre-B leukemic cells. $J$. Immunol. 156:564-573.

- Zhao, H. y Peeters, B. P. (2003). Recombinant Newcastle disease virus as a viral vector: effect of genomic location of foreign gene on gene expression and virus replication. J. Gen. Virol. 84:781-788.

- Zhao, H., Janke, M., Fournier, P. y Schirrmacher, V. (2008). Recombinant Newcastle disease virus expressing human interleukin-2 serves as a potential candidate for tumor therapy. Virus Res. 136:75-80. 

ANEXO I

El código genético

Nomenclatura de aminoácidos 


\section{EL CÓDIGO GENÉTICO}

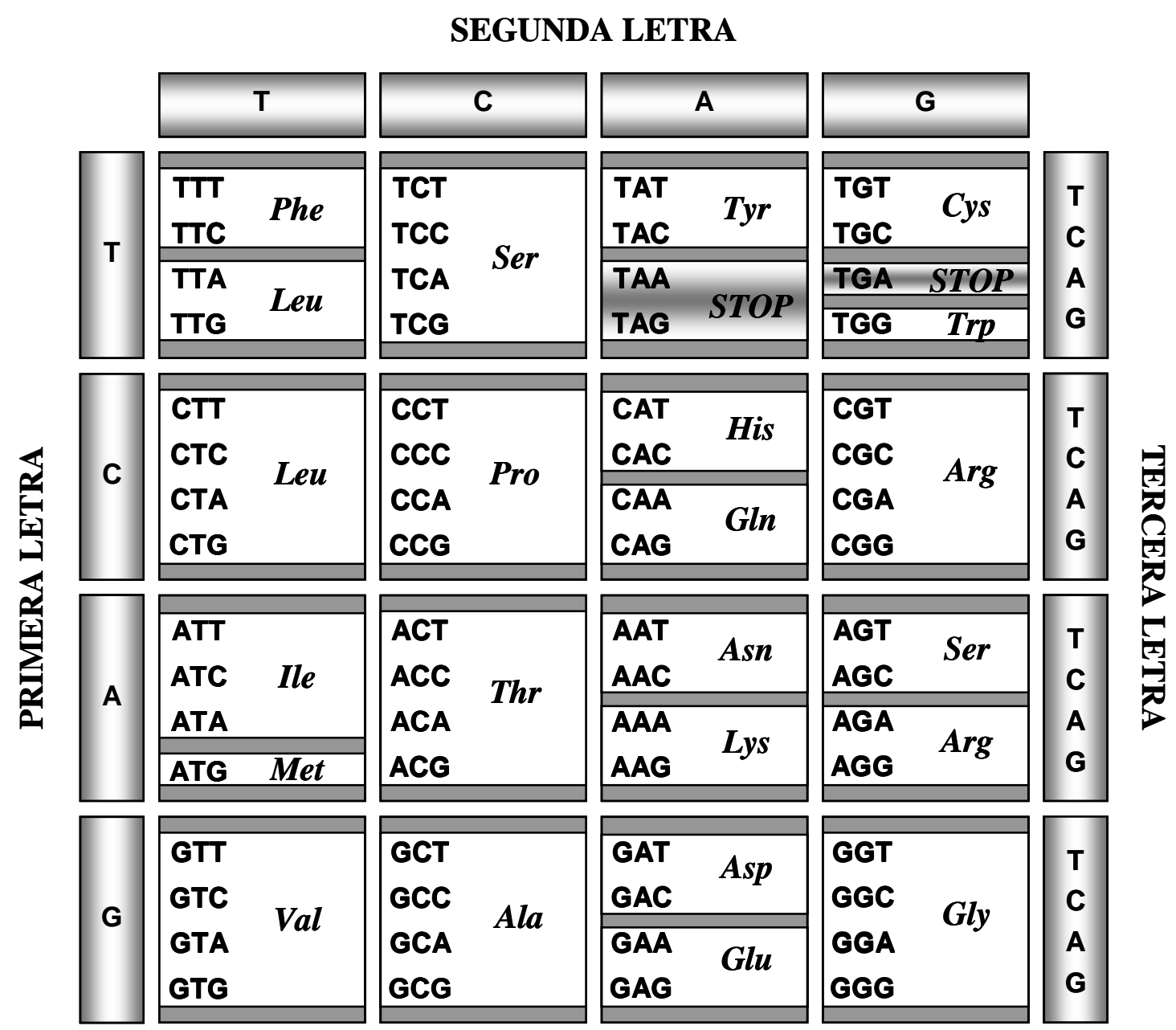

NOMENCLATURA DE LOS AMINOÁCIDOS

\begin{tabular}{|ccc|ccc|}
\hline Nombre & Tres letras & Una letra & Nombre & Tres letras & Una letra \\
\hline Alanina & Ala & A & Isoleucina & Ile & I \\
Arginina & Arg & R & Leucina & Leu & L \\
Asparragina & Asn & N & Lisina & Lys & K \\
Aspartato & Asp & D & Metionina & Met & M \\
Cisteína & Cys & C & Prolina & Pro & P \\
Fenilalanina & Phe & F & Serina & Ser & S \\
Glicina & Gly & G & Treonina & Thr & T \\
Glutamina & Gln & Q & Triptófano & Trp & W \\
Glutamato & Glu & E & Tirosina & Tyr & Y \\
Histidina & His & H & Valina & Val & V \\
\hline
\end{tabular}





\section{ÍNDICE DE TABLAS y FIGURAS}

TABLAS

Página

1.1. Las familias de los virus RNA(-).................................................. 3

1.2. Clasificación de la familia Paramyxoviridae ...................................... 6

1.3. Ingenieria genética en virus animales DNA y RNA(+)..................... 34

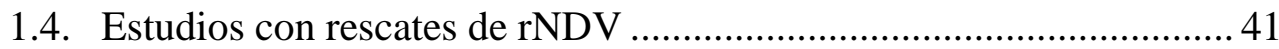

3.1. Anticuerpos empleados en el presente trabajo ................................. 70

3.2. Secuencias de los oligonucleótidos cebadores para PCR ................... 88

3.3. Oligonucleótidos empleados en mutagénesis dirigida........................ 96

3.4. Oligonucleótidos empleados en secuenciación, RT-PCR y

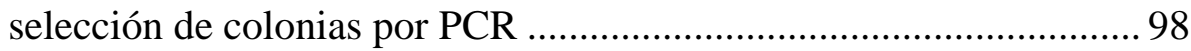

4.1. Expresión en superficie de los distintos mutantes y reactividad con $\mathrm{mAb} 2 \mathrm{~A} 6$ 157

FIGURAS

Página

1.1. Estructura del NDV ....................................................................... 10

1.2. Organización del genoma del NDV ................................................. 13

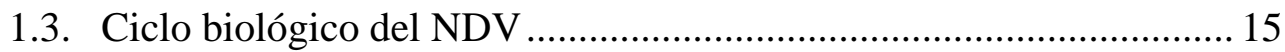

1.4. Síntesis de RNA en el NDV y otros paramixovirus ........................... 19

1.5. Formación de vesículas intraluminales en liposomas por la adición de proteína M del NDV purificada........................................................ 20

1.6. Estructura de la proteína $\mathrm{F}$ de los paramixovirus .............................. 22

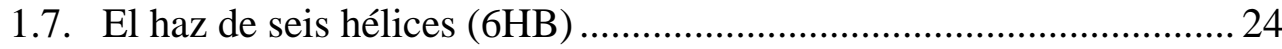

1.8. Plegamiento y replegamiento de DIII y HRA ................................... 27 
1.9. Modelo de fusión de membranas mediada por F................................. 30

1.10. Evolución del rescate de virus RNA(-)............................................. 37

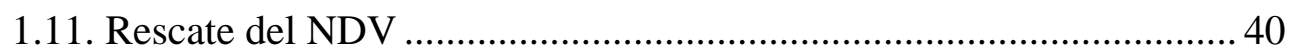

1.12. Expresión in vivo de genes foráneos por rNDV y replicación

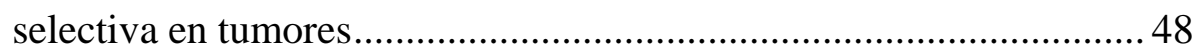

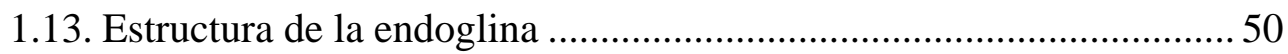

3.1. Mapa del vector pTM1 _............................................................... 72

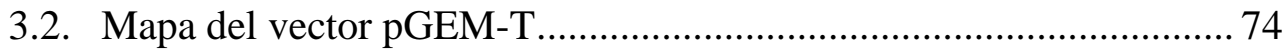

3.3. Representación esquemática de pNDV-B1 y pNDV-F3A ................. 76

3.4. Estructura del vector lanzadera pGEM-NDV-F\TMCyt .................. 77

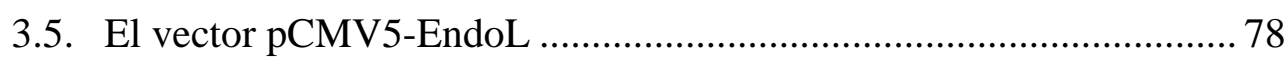

3.6. Mapa del vector pCAGGs ............................................................... 79

3.7. Estrategias de clonación en pNDV .................................................. 87

3.8. Anatomía de un huevo de pollo de 10 días y procedimiento

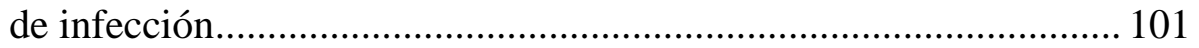

3.9. Interpretación de los resultados de un estudio de citometría de flujo 108

3.10. Fundamento e interpretación de un ensayo de hemaglutinación ............................................................................ 110

3.11. Fundamento e interpretación de un ensayo de transferencia de sonda

4.1. Proceso de construcción de pNDV-Endo y pNDV-EExC/F-TMCyt

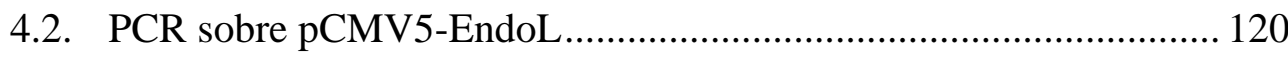

4.3. Análisis por PCR sobre colonias con pGEM-EExC........................ 121

4.4. Digestión de pGEM-Endo con XbaI............................................. 122

4.5. Digestión con NheI de pGEM-EExCIF-TMCyt............................................ 123

4.6. Análisis por PCR sobre colonias con pNDV-B1-Endo y pNDV-F3A-Endo

4.7. Análisis por PCR sobre colonias con pNDV-B1-EExC/F-TMCyt y pNDV-F3A-EExC/F-TMCyt.

4.8. Secuencias de reconocimiento para XbaI y NheI 
4.9. Análisis de restricción de pNDVs-Endo

y pNDVs-EExC/F-TMCyt 126

4.10. Estrategia de secuenciación de los insertos Endo

y EExC/F-TMCyt

4.11. Secuencia de L-endoglina humana en pNDV-B1-Endo y pNDV-F3A-Endo

4.12. Secuencia de la quimera con el dominio extracelular de L-endoglina los dominios transmembrana y citoplasmático de NDV F en pNDVB1-EExC/F-TMCyt y pNDV-F3A-EExC/F-TMCyt.

4.13. Proceso de rescate de los rNDV 132

4.14. Inmunofluorescencia sobre células infectadas con los rNDV-Endo y rNDV-EExC/F-TMCyt

4.15. Expresión de endoglina en células infectadas

(Western-Blot y RT-PCR)

4.16. Western blot sobre virus rNDV-Endo

y rNDV-EExC/F-TMCyt

4.17. SDS-PAGE de viriones purificados 138

4.18. Inmunofluorescencia sobre células mesangiales infectadas con rNDV-F3aa-mRFP y rNDV-F3aa-Endo.

4.19. Expresión de endoglina a distintos tiempos en células infectadas

4.20. Expresión y acumulación de proteínas de la matriz extracelular tras la sobreexpresión de endoglina llevada a cabo por rNDV 143

4.21. Clonación de $F$ y $H N$ en pGEM-T 151

4.22. Localización de las mutaciones en la proteína F ............................. 153

4.23. Análisis de restricción de los plasmidos mutados ........................... 155

4.24. Digestión de pCAGGs-Fwt y pCAGGs-HN con ClaI/BglIII........... 156

4.25. Análisis de la expresión en la superficie celular de las proteínas F mutantes por citometría de flujo 158

4.26. Expresión de las proteínas mutantes detectada por inmunofluorescencia 160

4.27. Ensayo de formación de sincitios para el análisis de la fusión célula-célula 
4.28. Ensayos de transferencia de sonda para cuantificar la

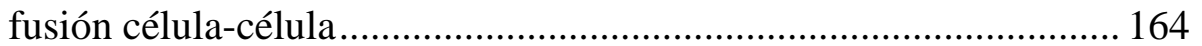

4.29. Transferencia de sonda de los mutantes N211A, I463A e I463F con distintas cantidades de DNA transfectado 165

4.30. Actividad fusogénica de los mutantes N211A, I463A e I463F en presencia y ausencia de $\mathrm{HN}$ 167

4.31. Efecto de la temperatura sobre la fusión promovida por los mutantes de la proteína $\mathrm{F}$ 169

4.32. La mutación N211A, el dominio DIII y HRA................................. 172

4.33. La mutación Q454A y el conector HRB ......................................... 174

4.34. Los aminoácidos L461 e I463 ......................................................... 176 

